\title{
Fort Bragg Old Post Historic District Landscape Report
}

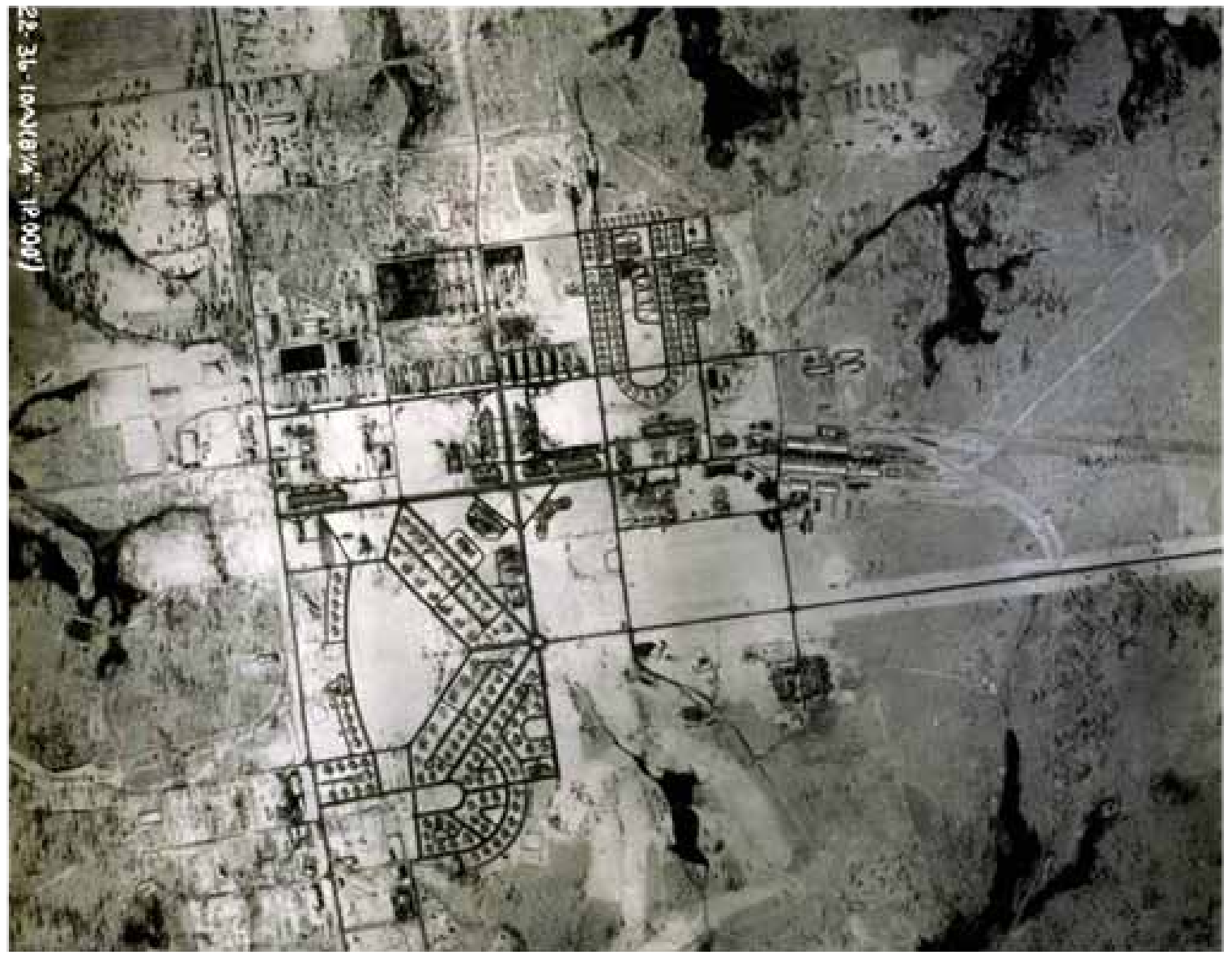





\section{Fort Bragg Old Post Historic District Landscape Report}

Megan Weaver Tooker, Ellen Hartman, and Adam Smith

Construction Engineering Research Laboratory (CERL)

U.S. Army Engineer Research and Development Center

2902 Newmark Dr.

Champaign, IL 61822-1076

Final Report

Approved for public release; distribution is unlimited.

Prepared for U.S. Army Garnison, Fort Bragg

Cultural Resources Management Program

Building 3-1333

Directorate of Public Works

Fort Bragg, NC 28310 


\begin{abstract}
This document provides an inventory and evaluation of the historic landscapes within the Old Post Historic District (OPHD) at Fort Bragg, and serves to meet the requirements for Federal agencies to address their cultural resources, defined as any prehistoric or historic district, site, building, structure, or object, specifically, Section 110 that requires Federal agencies to inventory and evaluate their cultural resources.
\end{abstract}

The report discusses the OPHD layout and design, its periods of significance, and historic landscapes and landscape features significant to the district. Several significant landscapes within the OPHD are identified, including the parade ground, Normandy Heights and Bastogne Gables Housing Areas, Ryder Golf Course, polo field, mule barn area, support buildings landscape such as the chapel, theater, headquarters, Bachelor Officers' Quarters, Officers' Club, former hospital and nurses' quarters and barracks, and the industrial area. Important character-defining open spaces within the contributing landscapes include the parade field, polo field, Ryder golf course, Bowley Field, Ruth Field, the traffic circle, former "civic center" area, chapel area, and the triangular areas in front of the old hospital and headquarters. This report also includes planting recommendations for significant landscapes within the OPHD to improve the integrity and create historic continuity within the district.

DISCLAIMER: The contents of this report are not to be used for advertising, publication, or promotional purposes. Citation of trade names does not constitute an official endorsement or approval of the use of such commercial products. All product names and trademarks cited are the property of their respective owners. The findings of this report arenot to beconstrued as an official Department of the Army position unless so designated by other authorized documents. 


\section{Table of Contents}

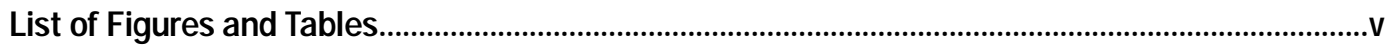

Preface

Unit Conversion Factors ........................................................................................................

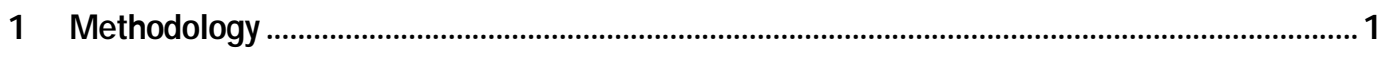

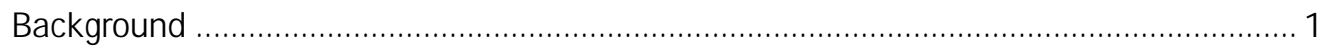

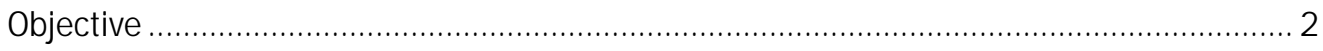

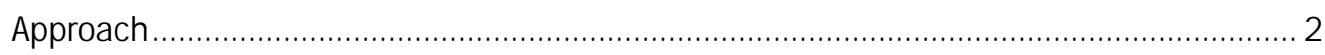

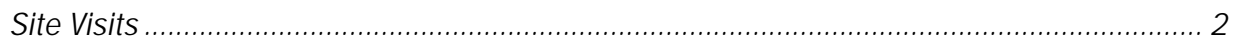

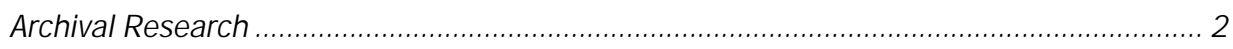

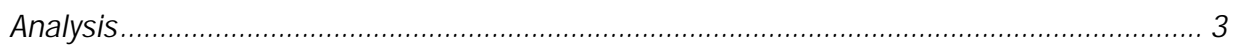

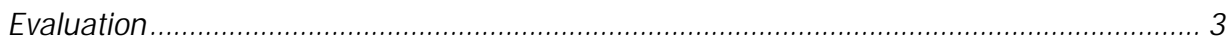

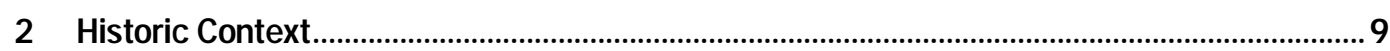

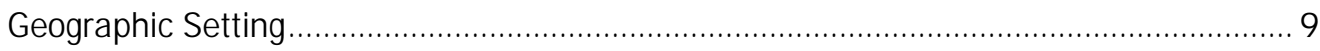

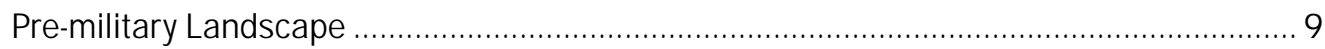

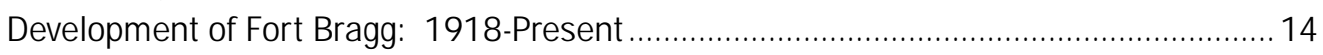

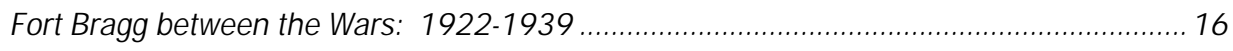

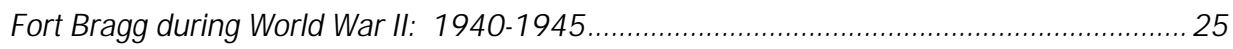

Post WuI Fort Bragg: 1946-1951 ….....................................................................2

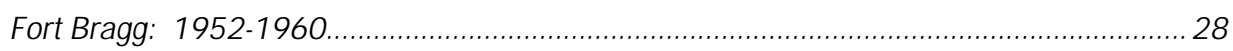

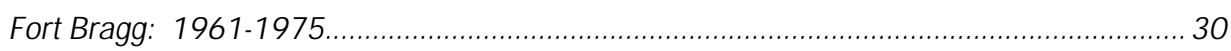

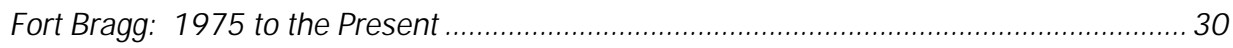

3 Identification of Character-Defining Landscape Features ....................................................33

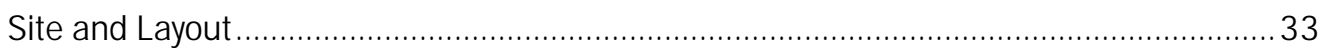

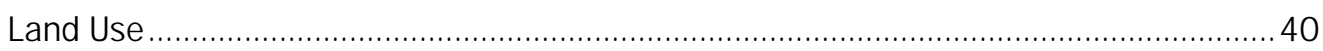

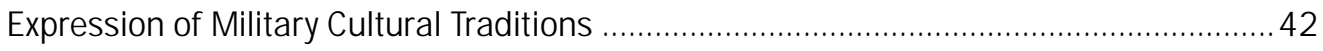

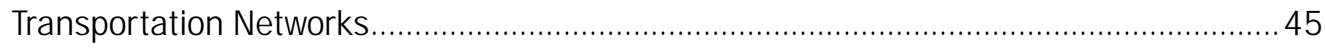

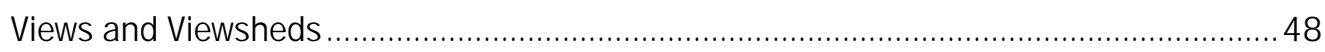

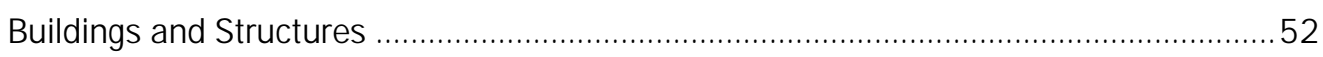

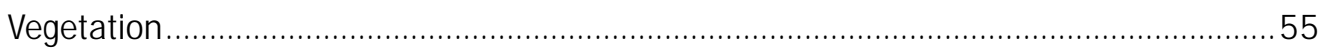

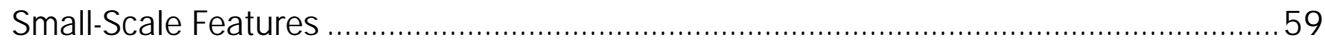

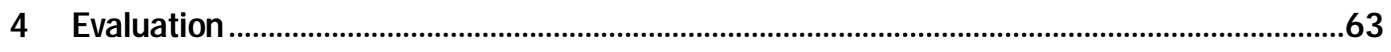

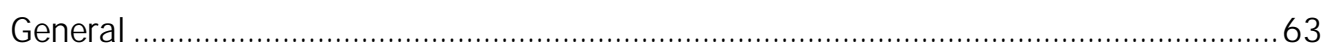

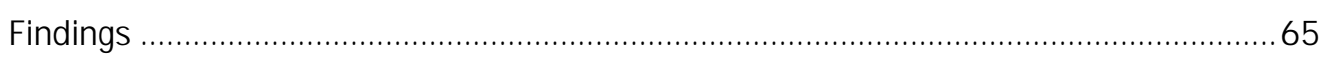




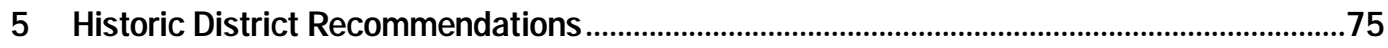

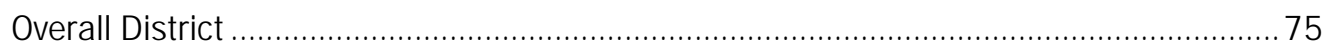

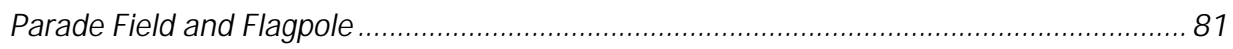

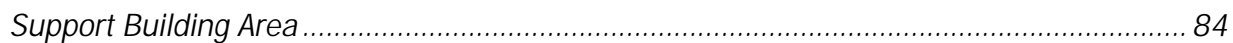

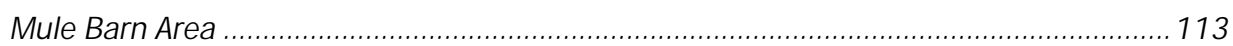

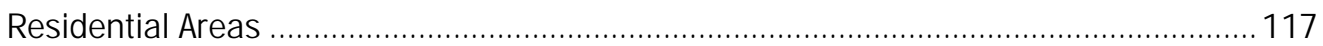

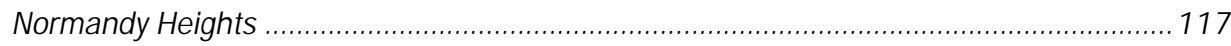

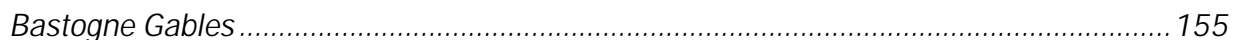

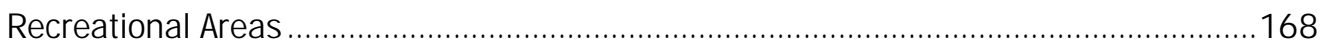

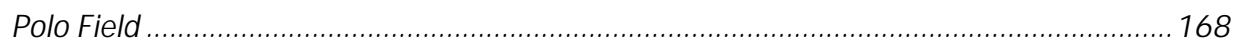

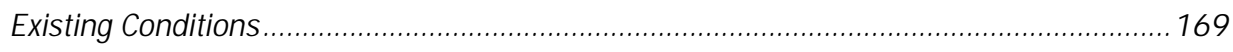

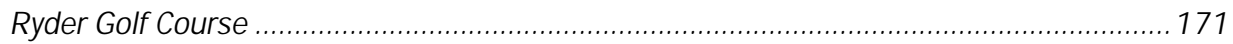

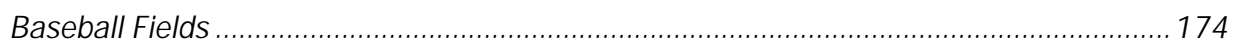

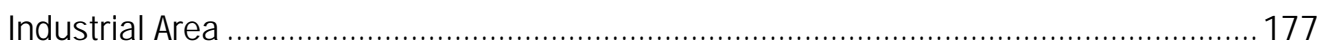

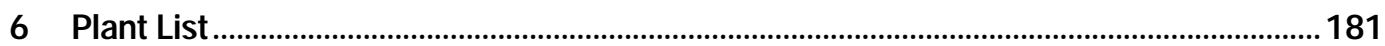

List of Historically and Regionally Appropriate Plants ...................................................186

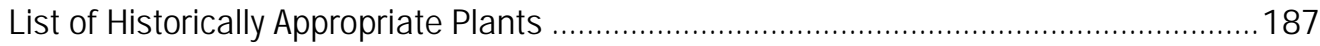

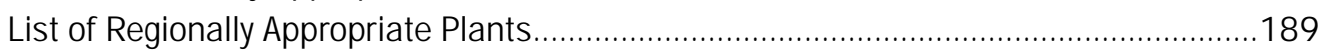

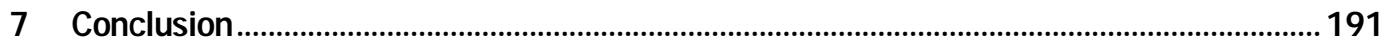

Acronyms and Abbreviations ............................................................................................ 193

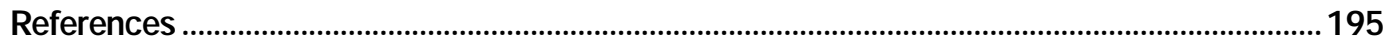

Appendix A: Characteristics, Features, and Landscape Elements Historically

Significant in Fort Bragg's Old Post Historic District ............................................................. 199

Appendix B: Armys Standardized Planting Plans from 1933 .................................................203

Appendix C: Plant List Taken from the Army's 1933 Standardized Planting Plans ..................213

Appendix D: Appropriate and Inappropriate Plants for Fort Bragg.........................................223

Appendix E: Plant Vendors List for North Carolina ..................................................................229

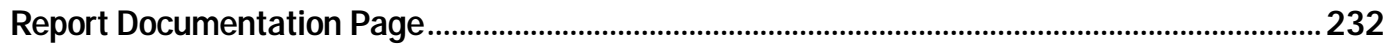




\section{List of Figures and Tables}

Figure

Page

1 Map of Fort Bragg's location in North Carolina, (Fort Bragg Cultural Resources)

2 Map of Fort Bragg military installation. The OPHD is highlighted in red, the black dots denote historic cemeteries, 1968 (Fort Bragg Cultural Resources)

3 Map of Fort Bragg's OPHD (drawn byJaime Grant, 2009, Fort Bragg Cultural Resources)

4 Long Street Church (Fort Bragg Cultural Resources)

5 Sandy Grove Church (Fort Bragg Cultural Resources)

12

$6 \quad$ 1918-1919 Map of Camp Bragg (Fort Bragg Cultural Resources) 15

7 Camp Bragg rail line; magazines, Pender Street, undated (Fort Bragg Cultural Resources) 17

8 Aerial view of Camp Bragg, 1920s (Fort Bragg Cultural Resources) 18

9 Aerial view of Camp Bragg 1924 (National Archives and Records Administration [NARA] College Park RG342-FH, box 1060, photo B17355)

10 Building plan of Fort Bragg, 1930 (Fort Bragg Cultural Resources) 20

111931 Aerial view of Fort Bragg looking southeast (Fort Bragg Cultural Resources) 22

12 Aerial view of Fort Bragg, 1936 (Fort Bragg Cultural Resources) 23

13 Post Headquarters (Building 1-1333) on left with Post Hospital (1-1326) in 1939 (NARA College Park RG342-FH, box 1060, B17347)

14 Normandy Heights officers' housing, 1941 (Fort Bragg Cultural Resources) 24

15 Main Post and Cantonment, September 1941 (Fort Bragg Cultural Resources) 26

16 WMI temporarybarracks (Fort Bragg Cultural Resources) 27

17 2nd Platoon, Company B, 1st Airbome Battle Group, 503rd Infantryin front of a Fort Bragg hammerhead barrack in 1962 (NARACollege Park RG111-SC 596852) 29

18 Womack Army Hospital in 1959 (NARACollege Park RG111-SC 566029) 29

19 Aerial of the OPHD November 1968; looking north the old hospital is on the left with the administration building on the right (Fort Bragg Cultural Resources)

20 Aerial view of the OPHD looking north, 1969 (Fort Bragg Cultural Resources) 31

21 Map of OPHD, 1993 (Fort Bragg Cultural Resources) 32

22 Plan of Fort Bragg by George B. Ford, 1926 (Fort Bragg Cultural Resources) 36

23 Plan of Fort Bragg showing layout, organization, and permanent construction, 1935 (Fort Bragg Cultural Resources) 37

24 Normandy Heights chevron highlighted on a 1935 map (Fort Bragg Cultural Resources) 38

25 Aerial view looking north along Hamilton Street showing the civic center at the far left and the polo field in the middle ground, 1920s (Fort Bragg Cultural Resources) 39

Aerial view looking northeast showing the civic center in the middle ground, 1940s (Fort
Bragg Cultural Resources)

27 Sixth Field Artillery Battalion with horse drawn artillery, 1941 (Fort Bragg Cultural Resources)

28 Motor Transport District, former mule bams, 27 August 1942 (NARA111-SC box 92 146190) 
Figure

Page

29 Relationship between Normandy Heights, Headquarters, and the hospital, 1968 aerial view looking east (Fort Bragg Cultural Resources)

30 Aerial view of the OPHD, 1946 (Fort Bragg Cultural Resources) 43

31 Soldiers in front of mule barns, undated (Fort Bragg Cultural Resources) 44

32 Street paving, combined curb and gutter, intersection of Randolph and Armistead, looking west, undated (NARARG-77-391 Boxes 49-52)

33 41st Engineers on the march, showing the roads of Fort Bragg, 1942 (Library of Congress LC-USWB- 000502-D [P\&P])

34 Plat showing the Cape Fear Railroad network, 1934 (Fort Bragg Cultural Resources) 47

351935 map of Fort Bragg showing rail lines in the OPHD, (Fort Bragg Cultural Resources) 48

36 Map of OPHD viewshed boundaryand buffer area (Fort Bragg Cultural Resources) 49

37 View north from the parade field to the Main Post Chapel, 2009 (ERDC-CERL) 50

38 View east along Randolph Street framed bystreet trees looking toward Iron Mike sculpture, 2009 (ERDC-CERL)

51

39 Vew east through Dupont Plaza, 2009 (ERDC-CERL)

51

40 Field and Company Officers' Quarters in the standardized Spanish Eclectic style, 1941 (Fort Bragg Cultural Resources)

41 Aerial image of Fort Bragg looking south showing the barracks, administration/ hospital, and housing areas, 1939 (NARARG-342-FH-bx1060-B17347[1939OPHD.])

42 Aerial image of Enlisted Men's Barracks, 1939 (National Archives RG-342-FH-bx1060B17348)

43 Field and company officers' quarters, looking south on Armistead Street, 1941 (Fort Bragg Cultural Resources)

44 One of the Macomb Barracks converted to the headquarters building showing foundation plantings, undated (NARASC111, Box 220, 386330)

45 Postcard illustrating the house of the commanding general, 1940s (Fort Bragg Cultural Resources)

46 Postcard showing the vegetation around the Field Artillery Board Headquarters, 1930s (Fort Bragg Cultural Resources)

471933 standardized planting plans for headquarters, bachelor officers' quarters, and barracks (Fort Bragg Cultural Resources)

481933 standardized planting plans for theater, chapel, and hospital (Fort Bragg Cultural Resources)

491933 standardized planting plans for Company Officers' quarters and double NCO quarters (Fort Bragg Cultural Resources)

50 Iron Mike Sculpture, 2009 (ERDC-CERL)

51 Flag pole looking west toward parade field, 2009 (ERDC-CERL) 61

52 Several of the memorials around the flagpole area, 2009 (ERDC-CERL).Evaluation 62

53 Layout development of the present-day OPHD (Fort Bragg Cultural Resources) 67

54 Map of significant historic open spaces in OPHD, 2010 (Fort Bragg Cultural Resources \& ERDC-CERL)

55 OPHD with contributing landscapes highlighted, 2009/2010 (Fort Bragg Cultural Resources and ERDC-CERL) 
56 Aerial view of the original layout of the OPHD looking north, 1920s (Fort Bragg Cultural Resources)

57 OPHD overall design recommendations, 2010 (ERDC-CERL) 79

58 Parade field looking toward the Post Flagpole, 1941 (Fort Bragg Cultural Resources) 81

59 Parade field reviewstand looking northeast, 2009 (ERDC-CERL) 82

60 Flagpole area with parade field in the background, 2009 (ERDC-CERL) 83

61 Parade field looking east toward the flagpole showing the perimeter framed in trees and the chapel on the left side, 2009 (ERDC-CERL)

62 Parade field with the flagpole area on the right, 2009 (ERDC-CERL)

63 Aerial view showing the administrative core at the intersection of Macomb and Armistead Streets, 1960s (Fort Bragg Cultural Resources)

64 Post Headquarters, 1941 (Fort Bragg Cultural Resources) 86

65 Station Hospital, 1941 (Fort Bragg Cultural Resources) 87

66 Nurses' Quarters, 1941 (Fort Bragg Cultural Resources) 87

67 Theater, 1940s (NARARG-77-391 Boxes 49-52) 88

68 Officers' Cub, 1941 (Fort Bragg Cultural Resources) 88

69 The old hospital, now the headquarters for the 82nd Airbome Division, 2009 (ERDC-CERL) 90

70 The chapel landscape, 2009 (ERDC-CERL) 90

71 Former Officers' Gub, 2007 (ERDC-CERL) 91

72 Theater on the left, converted barracks on the right, 2009 (ERDC-CERL) 91

73 Red Cross Building landscape, 2009 (ERDC-CERL) 92

74 Irregularly planted hedgerow, 2009 (ERDC-CERL) 94

75 Modem pavers used as border, 2009 (ERDC-CERL) 94

76 Plan view of proposed planting plan for the former headquarters (ERDC-CERL) 95

77 Elevation view of proposed planting for the former headquarters (ERDC-CERL) 97

78 Plan view of proposed plantings for the old hospital (ERDC-CERL) 99

79 Elevation view of the planting plan for the old hospital (ERDC-CERL) 101

80 Plan view of planting plan for the theater (ERDC-CERL) 103

81 Elevation view of planting for the theater ERDC-CERL) 105

82 Plan view of planting plan for chapel (ERDC-CERL) 107

83 Elevation view of plantings for the chapel (ERDC-CERL) 109

84 Plan view of planting plan for barracks (ERDC-CERL) 111

85 Elevation view of plantings for barracks (ERDC-CERL) 113

86 Horses and mules in mule bam area, undated (Fort Bragg Cultural Resources) 114

87 Former mule bams converted to the Motor Transport District, 1942 (NARA 111-SC box 92 146352)

88 Former Stable Guard Quarters converted to the Motor Transport District, 1942 (NARA 111SC box92 146189)

89 Former Stable Guard Quarters now administrative space, 2009 (ERDC-CERL) 116

90 Example of existing landscape around the mule bams, 2009 (ERDC-CERL) 117 
Figure

Page

91 Normandy Heights neighborhood, 1946 (Fort Bragg Cultural Resources) 118

92 Aerial view of the Normandy Heights neighborhood, 1930s (Fort Bragg Cultural Resources) 119

93 Ranch style housing in Normandy Heights, 1941 (Fort Bragg Cultural Resources) 120

94 Postcard illustrating officers' quarters with plantings, 1940s (Fort Bragg Cultural Resources)

95 Normandy Heights Officers' Quarters, showing uniform, well-maintained foundation plantings and wide front lawns, 2009 (ERDC-CERL)

96 Normandy Heights ranch-style house type showing orderly foundation plantings, 2009 (ERDC-CERL)

97 Normandy Heights duplex showing a variety of vegetation types, 2009 (ERDC-CERL)

98 Plan view of proposed planting plan for two-story quarters in Normandy Heights neighborhood, 2010 (ERDC-CERL)

99 Elevation view of proposed planting plan for two-story quarters in Normandy Heights (ERDC-CERL)

100 Plan view of proposed planting plan for two-story quarters in Normandy Heights neighborhood, 2010 (ERDC-CERL)

101 Elevation view of proposed planting plan for two-story quarters in Normandy Heights (ERDC-CERL)

102 Plan view of proposed planting plan for two-story quarters in Normandy Heights neighborhood, 2010 (ERDC-CERL)

103 Elevation view of proposed planting plan for two-story quarters in Normandy Heights (ERDC-CERL)

104 Plan view of proposed planting plan for duplex quarters in Normandy Heights neighborhood, 2010 (ERDC-CERL)

105 Elevation view of proposed planting plan for duplex quarters in Normandy Heights (ERDCCERL)

106 Plan view of proposed planting plan for duplex quarters in Normandy Heights neighborhood, 2010 (ERDC-CERL)

107 Elevation view of proposed planting plan for duplex quarters in Normandy Heights (ERDCCERL)

108 Plan view of proposed planting plan for ranch style quarters in Normandy Heights neighborhood, 2010 (ERDC-CERL)

109 Elevation view of proposed planting plan for ranch-style quarters in Normandy Heights (ERDC-CERL)

110 Plan view of proposed planting plan for ranch-style quarters in Normandy Heights neighborhood, 2010 (ERDC-CERL)

111 Elevation view of proposed planting plan for ranch-style quarters in Normandy Heights (ERDC-CERL)

112 Plan view of proposed planting plan for ranch-style quarters in Normandy Heights neighborhood, 2010 (ERDC-CERL)

113 Elevation view of proposed planting plan for ranch-style quarters in Normandy Heights (ERDC-CERL)

114 Aerial, looking south, of Bastogne Gables and Humphrey Plaza, 1968 (Fort Bragg Cultural Resources)

115 Non Cormmissioned Officers' Housing, Bastogne Gables, 1941 (Fort Bragg Cultural Resources) 
Figure

Page

116 Bastogne Gables houses and open space, 2009 (ERDC-CERL) 158

117 Bastogne Gables streetscape, 2009 (ERDC-CERL) 158

118 Bastogne Gables front plantings, 2009 (ERDC-CERL) 159

119 Plan view of proposed planting plan for Bastogne Gables neighborhood (ERDC-CERL) 161

120 Elevation view of proposed planting for Bastogne Gables neighborhood (ERDC-CERL) 163

121 Plan view of proposed planting plan for Bastogne Gables neighborhood (ERDC-CERL) 165

122 Elevation view of proposed plantings in Bastogne Gables neighborhood (ERDC-CERL) 167

123 Polo field, 1941 (Fort Bragg Cultural Resources) 168

124 Looking west across the polo field, 2009 (ERDC-CERL) 169

125 Polo field is now used for other sports, 2009 (ERDC-CERL) 170

126 Polo field bounded with trees and showing the perimeter track, 2007 (ERDC-CERL) 170

127 Aerial view of officers' golf course, 1933 (Fort Bragg Cultural Resources) 172

128 Ryder Golf Course 2007 (ERDC-CERL) 173

129 Ryder Golf Course, 2007 (ERDC-CERL) 173

130 Normandy Heights neighborhood from Ryder Golf Course, 2007 (ERDC-CERL) 174

131 Map showing baseball fields north of barracks, 1993 (Fort Bragg Cultural Resources) 175

132 Aerial view of Bowley baseball field north of barracks, southwest of Bastogne Gables, 2010 (Pictometry Intemational Corporation) $\quad 175$

133 Bowley Field, 2010 (ERDC-CERL) 176

134 Aerial view of Ruth baseball field north of barracks south of mule bams, 2010 (Pictometry International Corporation) 176

135 Ruth Field, 2010 (ERDC-CERL) 177

136 Aerial view of the OPHD industrial area, 2010 (Microsoft Corp, NAVTEQ, USGS) 178

137 Former ordnance manufacturing building in the industrial area, 2007 (ERDC-CERL) 178

138 Former warehouse in the industrial area, 2010 (ERDC-CERL) 179

139 Former Firestone building in the industrial area, 2007 (Fort Bragg Cultural Resources) 179

140 Administrative building, former Field Artillery Board Headquarters, in industrial area, 2009 (ERDC-CERL)

180

141 Leaf structure of the Carolina Chemy Laurel, 2005 (University of Texas at Austin) 184

142 Wax Myrtle, 2005 (University of Texas at Austin) 184

143 Yaupon Holly, 2005 (University of Texas at Austin) 185

B1 Typical street tree planting diagrams, 1933 (Fort Bragg Cultural Resources) 205

1933 standardized planting plans for headquarters, BOQ, and barracks (Fort Bragg
Cultural Resources)

B3 1933 standardized planting plan for theater, chapel, and hospital (Fort Bragg Cultural Resources) 209

B4 1933 standardized planting plan for Commanding Officer's Quarters (COQ) and double NCOQuarters (Fort Bragg Cultural Resources) 
1 Contributing landscapes and their historic significance

2 Plants used in the 2010 design recommendations occuring on both the 1933 standardized planting plans for the OPHD and the Fort Bragg 2009 IDG Practical Plantings list (ERDC-CERL)

3 List of plants from the 1933 standardized planting plan that are historically appropriate as well as regionally acceptable to use in the OPHD at Fort Bragg (ERDC-CERL)

4 List of plants from the 2009 Installation Design Guidelines that are acceptable to use in the OPHD at Fort Bragg (ERDC-CERL)

A1 Characteristics, features, and documentation used for landscape evaluation, 2010 (ERDCCERL)

C1 Planting list from the Armys 1933 standardized planting plans (ERDC-CERL)

D1 Fort Bragg's IDG Practical Plantings list, December 2009 (Installation Design Guide for a Sustainable Fort Bragg)

D2 Plants native to North Carolina with their culture requirements, 2002 (Mooman, et al. Landscaping for Wildlife with Native Plants)

D3 Fort Bragg's IDG list of aggressive, invasive plant species that should not be planted on the installation, 2009 (Installation Design Guide for a Sustainable Fort Bragg)

E1 Plant Vendors for North Carolina adapted from a list revised by Erich Hoffman, 4 August 2008 (ERDC-CERL)

E2 Native plant vendor list (NC suppliers) for North Carolina compiled by the NCDivision of Water Quality (NC Division of Water Quality 2010)

E3 Native plant vendor list (out-of-state suppliers) for North Carolina compiled by the NC 


\section{Preface}

This study was conducted for Fort Bragg, NC, under Project No. 321461, "Fort Bragg Landscape Management Plan." Funding was provided by Military Interdepartmental Purchase Request (MIPR) MIPR9GCERP3431, dated 12 February 2009. The Fort Bragg technical monitor was Connie Barnett, Architectural Historian.

The work was performed by the Land and Heritage Conservation Branch (CN-C) of the Installations Division (CN), Construction Engineering Research Laboratory (CERL). Adam Smith was the CERL Project Manager and lead architectural historian; Megan Weaver Tooker and Ellen Hartman were the landscape architects. Special acknowledgement is given to those who assisted with the formation of this report: Michelle Michael, former Architectural Historian at Fort Bragg, members of the Fort Bragg Arbor Board, and J aime Grant, Archeologist and geographic information system (GIS) Specialist at Fort Bragg. Dr. Christopher White is Chief, CN$\mathrm{C}$, and Dr. J ohn Bandy is Chief, CN. The Deputy Director of CERL is Dr. Kirankumar V. Topudurti. The Director of CERL is Dr. Ilker R. Adiguzel.

CERL is an element of the U.S. Army Engineer Research and Development Center (ERDC), U.S. Army Corps of Engineers. The Commander and Executive Director of ERDC is COL Kevin J. Wilson, and the Director of ERDC is Dr. J effery P. Holland. 


\section{Unit Conversion Factors}

\begin{tabular}{|l|c|l|}
\hline Multiply & By & To Obtain \\
\hline acres & $4,046.873$ & square meters \\
\hline degrees Fahrenheit & $(\mathrm{F}-32) / 1.8$ & degrees Celsius \\
\hline feet & 0.3048 & meters \\
\hline gallons (U.S. liquid) & $3.785412 \mathrm{E}-03$ & cubic meters \\
\hline horsepower (550 foot-pounds force per second) & 745.6999 & watts \\
\hline inches & 0.0254 & meters \\
\hline miles (U.S. statute) & $1,609.347$ & meters \\
\hline square feet & 0.09290304 & square meters \\
\hline square miles & $2.589998 \mathrm{E}+06$ & square meters \\
\hline square yards & 0.8361274 & square meters \\
\hline yards & 0.9144 & meters \\
\hline
\end{tabular}




\section{Methodology}

\section{Background}

The U.S. Congress has enacted laws to preserve our national cultural heritage. The first major Federal preservation legislation was the Antiquities Act of 1906, which was instrumental in securing protection for archeological resources on Federal property. The benefits derived from this Act and subsequent legislation precipitated an expanded and broader need for the preservation of historic cultural resources. With this growing awareness, the U.S. Congress codified the National Historic Preservation Act of 1966 (NHPA), the most sweeping cultural resources legislation to date.

The U.S. Congress created the NHPA to provide guidelines and requirements for preserving tangible elements of our past primarily through the creation of the National Register of Historic Places (NRHP). In this legislation Sections 110 and 106 are requirements for Federal agencies to address their cultural resources, defined as any prehistoric or historic district, site, building, structure, or object. Section 110 requires Federal agencies to inventory and evaluate their cultural resources. Section 106 requires the determination of the effects of Federal undertakings on properties deemed eligible or potentially eligible for the NRHP.

Fort Bragg was established in 1918 as an artillery training camp and is now one of the premier military training installations in the world. It is home of the U.S. Army's only airborne corps (XVIII Airborne Corps), the Army's largest support command, and the Army's Special Forces operations. Fort Bragg is a community of more than 60,000 individuals. The population is comprised of approximately 40,000 military personnel, 11,000 dependents, and a civilian support force of 8000 . This is the largest total installation population in the Army.

A 1996 comprehensive architectural survey determined the Old Post Historic District (OPHD) at Fort Bragg was eligible for the National Register. The district was determined to form an architecturally cohesive unit significant under Criterion A for its role in military history and under Criterion $\mathrm{C}$ for its characteristics of Army planning and architecture during the interwar era (Little 2001). 


\section{Objective}

The objective of this effort was to develop and write a historic landscape context, inventory, and management plan for the OPHD at Fort Bragg. The significance and integrity of all landscapes in the OPHD area were evaluated for inclusion on the NRHP. Photographic and historical documentation was completed for any eligible landscapes, and general recommendations were made on how to preserve and/ or protect these resources in the future. Planting plans were also completed for a selection of building styles and types.

\section{Approach}

The researchers approached the objective by first performing a site visit that included a survey and inventory of the cantonment landscape; photographing, sketching site maps of major landscapes, and archival research.

\section{Site Visits}

Members of the research team conducted a site visit to survey the landscape and conduct research. The site visit occurred in J une 2009. During the site visit, researchers collected archival information such as maps and historic photographs from the installation and made preliminary determinations of historic eligibility. Researchers conducted site reconnaissance on foot and by car using photography, sketches, and note-taking to help understand the entirety of the cantonment landscape. Then discrete component landscapes were examined for integrity and NRHP eligibility.

\section{Archival Research}

Archival research involved: (1) the initial literature review, and (2) identification and location of primary research materials.

\section{Literature review}

The research team used secondary literature to determine the general history of the cantonment at Fort Bragg. This involved reading published and unpublished material found on the region, Fort Bragg, and its landscape. 
Research material

The research team then located primary research materials and additional secondary materials to establish a strategy to best use these resources. Members of the research team conducted a visit to the National Archives in College Park, MD.

\section{Analysis}

After the initial research was complete, the team analyzed the gathered information and resources. Historic maps and photographs were examined and compared to current day conditions. For those landscapes with significance based on the historic context and themes, a determination of integrity was made.

\section{Evaluation}

The evaluation of structures and landscapes follows the guidelines in National Register Bulletin \#15: How to Apply the National Register Criteria for Evaluation, and National Register Bulletin \#16 How to Complete the National Register Registration Form. In addition, the survey follows the Department of Defense guidance Documenting and Evaluating Historic Military Landscapes as well as National Register Bulletin \#30: Guidelines for Evaluating and Documenting Rural Historic Landscapes (ERDC-CERL).*

After the research was complete, the team analyzed the gathered information. Archival and field information was integrated throughout the course of the research, necessitating the integration of visual and written sources in the final report. Figures 1-3 situate Fort Bragg in North Carolina and the OPHD within the installation.

\footnotetext{
* Also referenced will be National Register Bulletin (no number): How To Prepare National Historic Landmark Nominations, National Register Bulletin \#18: How To Evaluate and Nominate Designed Historic Landscapes, National Register Bulletin \#30: Guidelines for Documenting and Evaluating Rural Historic Landscapes, Preservation Brief \#36: Protecting Cultural Landscapes, The Secretary of the Interior's Standards for the Treatment of Historic Properties with Guidelines for the Treatment of Cultural Landscapes, and the National Park Senvice's Guide to Gultural Landscape Reports.
} 


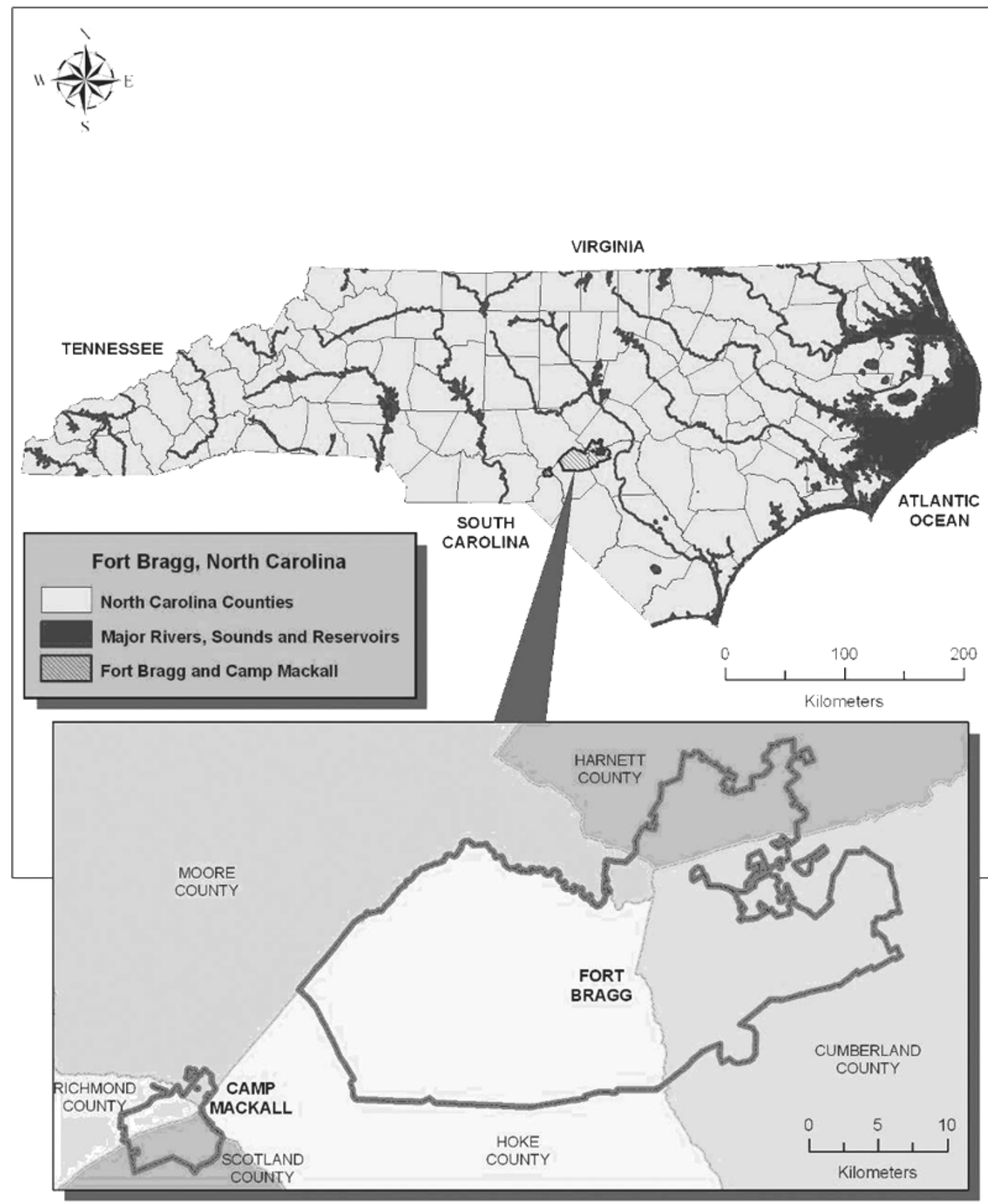

Figure 1. Map of Fort Bragg's location in North Carolina, (Fort Bragg Cultural Resources). 


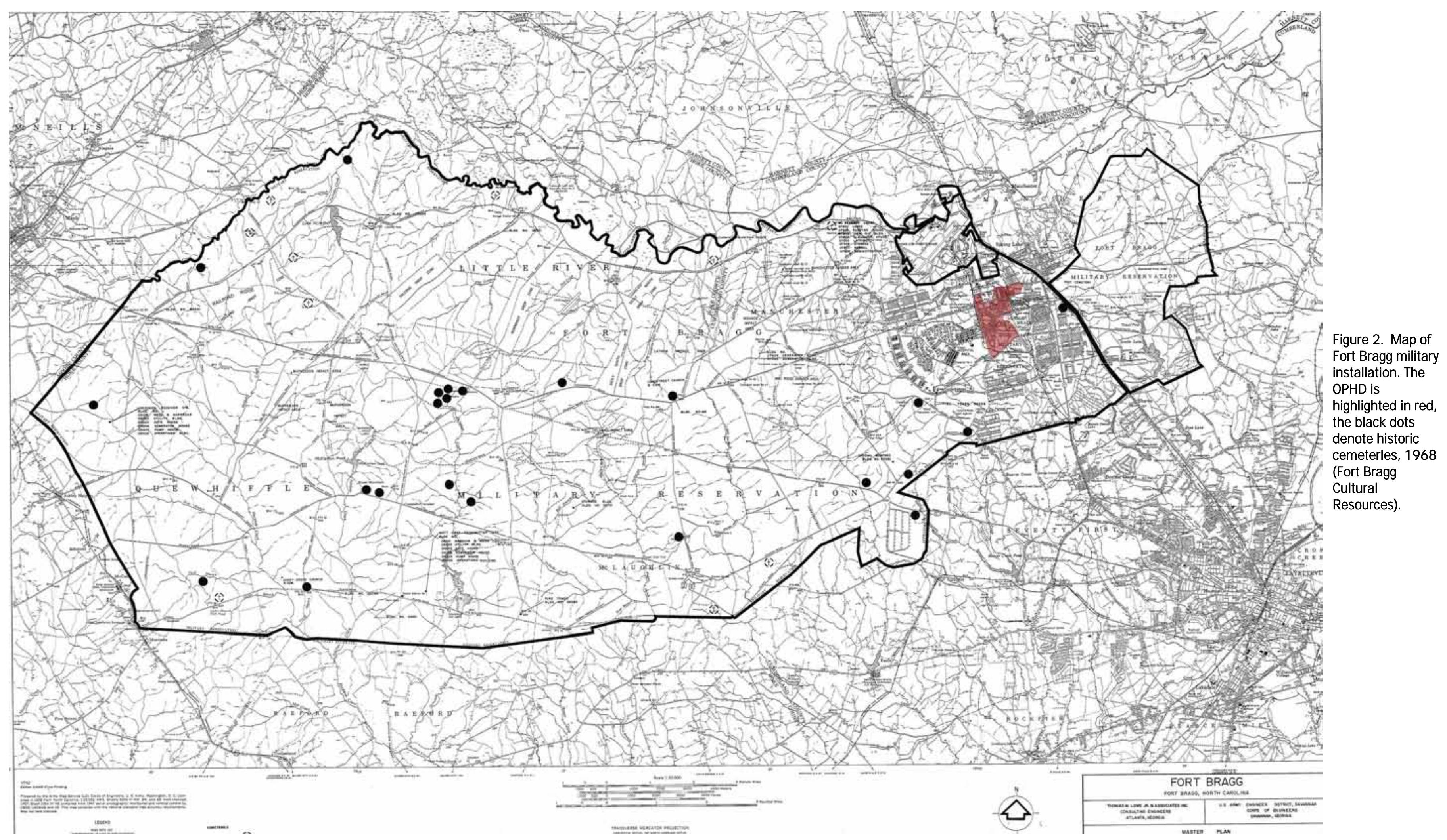




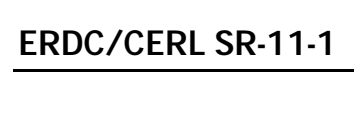




\section{Old Post Historic District Fort Bragg, North Carolina}
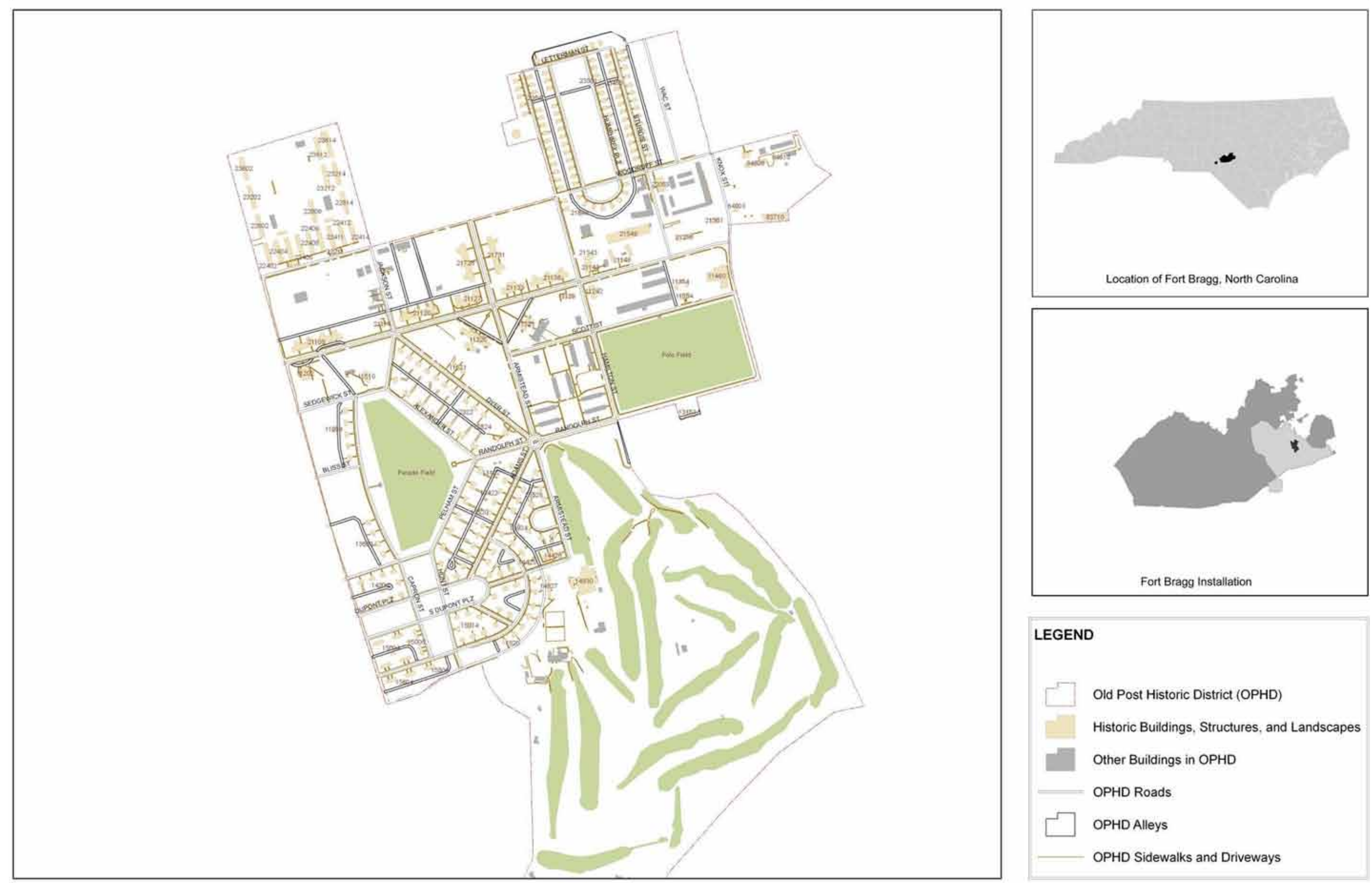

Figure 3. Map of Fort Bragg's

OPHD (drawn by Jaime Grant

, Fort Bragg Cultural

Fort Bragg Installation

LEGEND

Old Post Historic District (OPHD)

Historic Buildings, Structures, and Landscapes

Other Buildings in OPHD

OPHD Roads

OPHD Alleys

OPHD Sidewalks and Driveways

Created By Jaime Grant
Fort Bragg Cultural Resources Progra 


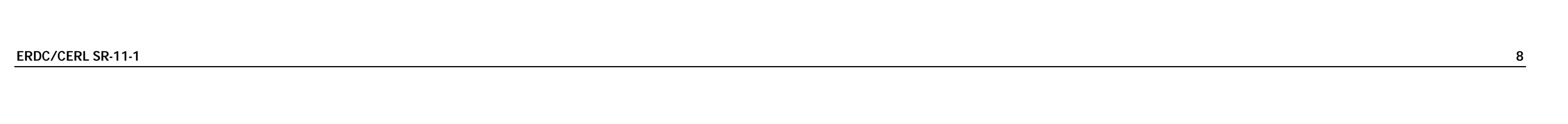




\section{Historic Context}

\section{Geographic Setting}

Fort Bragg is irregularly shaped and covers 153,562 acres within four counties. The cantonment is located in Cumberland County, with the range and training areas in Hoke, Cumberland, Harnett, and Moore counties (Figure 1). The Fort Bragg military installation is located 10 miles northwest of Fayetteville, NC, in the Piedmont region of the state. Nearby towns are Wilmington 90 miles southeast, Raleigh 50 miles northeast, and Charlotte 106 miles west. Major regional landmarks are the Cape Fear River 6 miles east; Interstate 9512 miles east; and Pinehurst Resort and Village 28 miles west (Nakata Planning Group and Rust Environment and Infrastructure, 1994; 1995).

The location of Fort Bragg is in the Sandhills physiographic province, which is a narrow band of xeric, sandy uplands. In North Carolina, the Sandhills are within the inner Coastal Plain, just east of the Fall Line- the line marking where waterfalls first appear on streams and rivers-in a climatic Subtropical-Temperate Zone. The Sandhills are predominantly composed of sand with few rock outcrops, however, there are several sandstone outcrops occurring on top of the Middendorf beds. These beds are characterized by little soil development and prominent ferruginous sandstone found along narrow hilltops. The Orangeburg Scarp runs southwestnortheast at an elevation of 60 to $70 \mathrm{~m}$, representing the highest ocean advancement during Pliocene through Pleistocene times ( Bartlett and Charles 1967).

\section{Pre-military Landscape}

This section provides a synthesized chronological sequence of the prehistoric and historic cultures that developed in the area of the southeastern Piedmont region and Sandhills province of North Carolina. Cultural chronology and settlement patterns with their effects on specific geographic areas were determined through the analysis of artifacts and other features of the archeological record. 
The earliest assumed human activity in the Piedmont area of North Carolina dates from about 10,500 B.C. Although humans have long inhabited this area, few traces of this prehistoric activity remain on the grounds of Fort Bragg. Native populations grew as sedentary, agriculturally-based lifestyles were adopted. European contact came in the $16^{\text {th }}$ century and the native inhabitants quickly adopted domesticated animals, such as cattle and pigs. In the wake of European settlement, the indigenous peoples of the Piedmont region experienced precipitous declines in population levels attendant with the spread of epidemic diseases. Remnant groups from various tribes were forced from their traditional homelands to marginal locations where they formed alliances with other displaced peoples; many moved to the area north of the J ames River near Fort Christiana, VA, while others merged with groups living to the south (Ward and Stephen Davis 1993).

The first permanent European settlements on the Lower Cape Fear River were established by English and Scots-Irish colonists in the mid 1720s (Lee 1963). The earliest known European settlement in the region now encompassed by Fort Bragg was apparently not established until the mid1740s (Meyer 1961). The presence of the Tuscarora-a powerful Indian group to the north-inhibited early colonial development on the entire Inner Coastal Plain of North Carolina until its destabilization and eventual break up after the Tuscarora War (1711- 1715) (Lee 1963; Parramore 1982). After this, the Europeans who predominantly settled the Sandhills area were Highland Scots, but large numbers of English and Scots-Irish also migrated from their settlements on the Lower Cape Fear.

During the Colonial period, most North Carolina settlers farmed for subsistence needs and exploited natural resources for profit. Initially, deerskins and other hides and furs were shipped out of the backcountry for trade and export, but the ubiquitous longleaf pine forests of the Sandhills proved to be of substantial economic value (Lefler and Powell 1973). Longleaf pines (Pinus palustris) produce higher quality pine resin/ crude gum than any other species of pine in eastern North America. The gum was used to produce pine tar, pitch, rosin, and turpentine contributing to the Republic's naval stores (Lefler and Powell 1973).

During the Revolutionary War (1776-1783) local inhabitants fought in a number of small-scale skirmishes that occurred in outlying areas surrounding Fayetteville. However, Lord Charles Cornwallis found the popu- 
lation seemingly apathetic to the cause of the crown and, while in route back to Wilmington to collect supplies, Cornwallis' regiments crossed the Lower Little River at Monroe's Bridge, which was located between the mouth of McPherson Creek and what is now the Camp Bragg water processing plant (Nye Undated). Cornwallis reportedly visited with Colonel Duncan Ray, a Loyalist, who lived in a home built by Malcolm Smith on Yadkin Road (Nye Undated). This site (31CD62) was later known as the "Cornwallis House" and became part of Camp Bragg in 1918. The house was later burned by the military, but the cellar depression, chimney, and foundation remains are still apparent above the ground surface (Loftfield 1979; Nye Undated).

The Antebellum period (1783-1860) was a time of economic prosperity and further community development in the Sandhills. The greater regional population growth in the antebellum period was generally centered in Cross Creek, the colonial economic hub of the Sandhills, and a number of smaller towns and hamlets in the Sandhills (Lee 1965; Merrens 1964; Tullos 1989). In 1783, the name Cross Creek was changed to Fayetteville to honor the Revolutionary War hero, General Marquis de LaFayette (Oates 1950).

In the area circumscribed by Fort Bragg, at least 10 historic churches existed in the nineteenth century, but little is known about these churches (e.g., denomination, founding dates) except for the Long Street (Figure 4) and Sandy Grove (Figure 5) Presbyterian churches, respectively built in 1845-1846 and 1854-55 (Loftfield 1979). Both churches held regular services until the properties were purchased and taken over by the U.S. Army in 1922. The two buildings and adjacent cemeteries are now protected and maintained by the U.S. Army. Although other church structures existed on Fort Bragg through the early 1920s, the U.S. Army sold or razed the buildings sometime after 1922. 


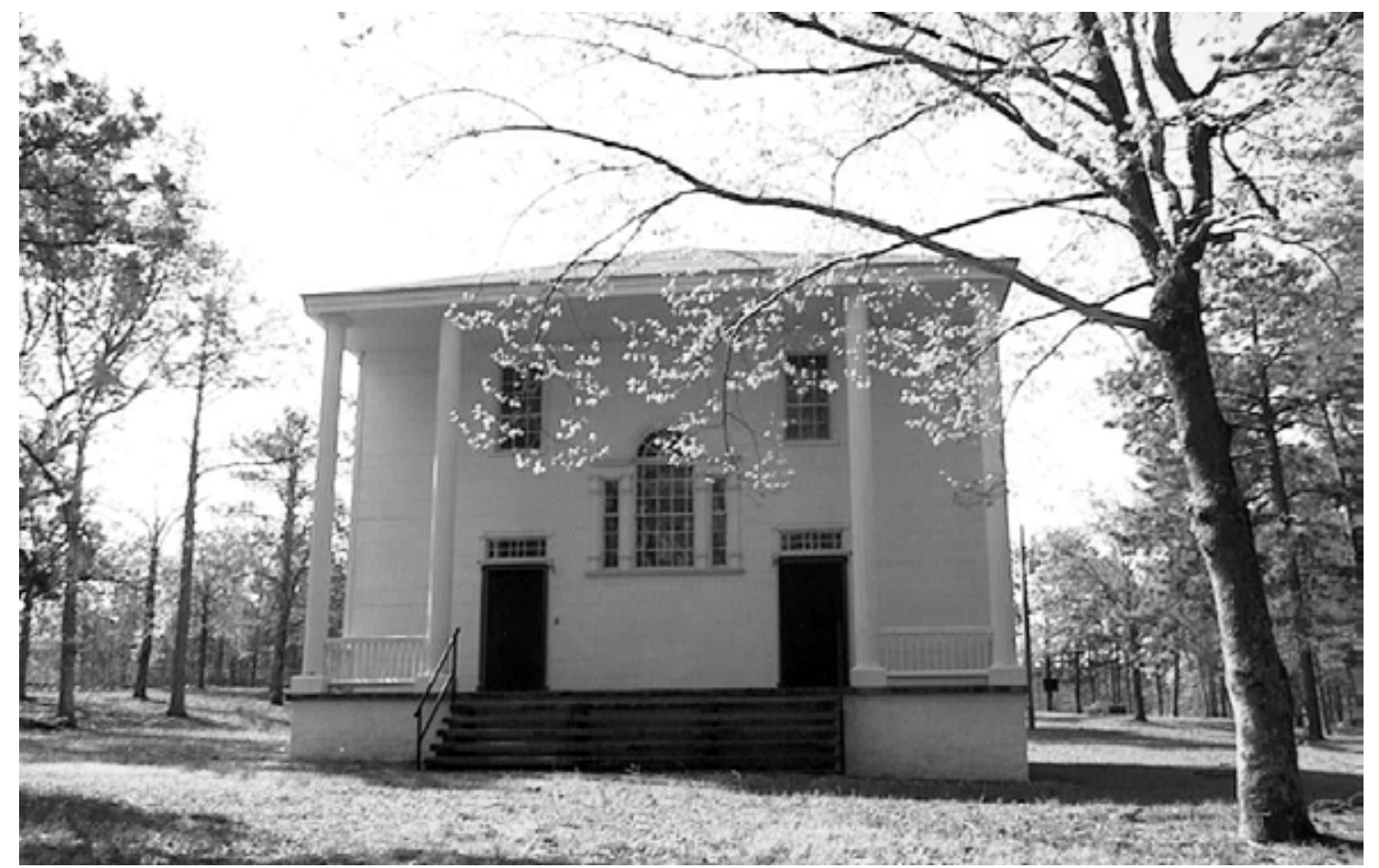

Figure 4. Long Street Church (Fort Bragg Cultural Resources).

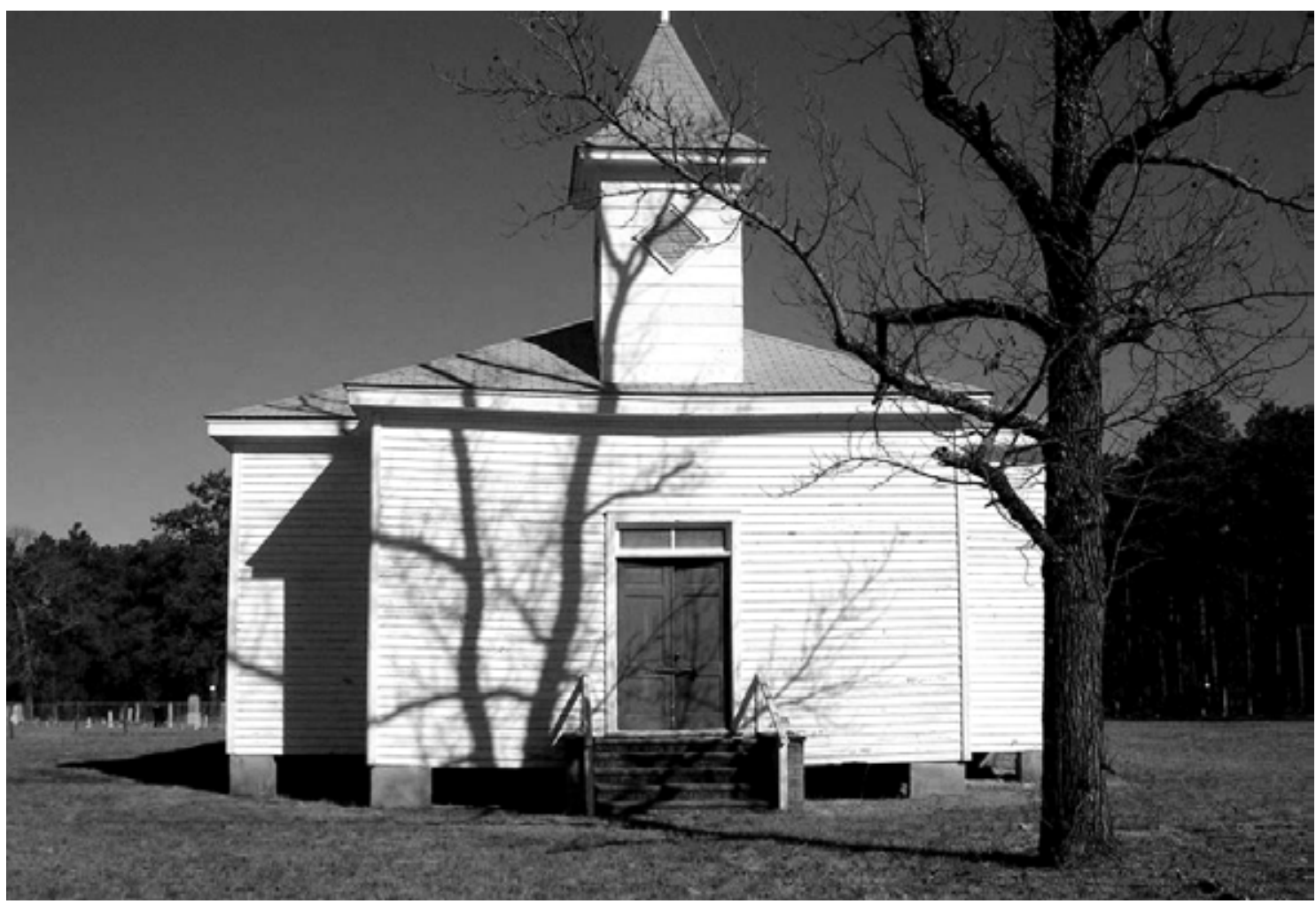

Figure 5. Sandy Grove Church (Fort Bragg Cultural Resources). 
During the Civil War, North Carolina did not formally secede from the Union until 20 May 1861, but on 26 April 1861 the State Military and Naval Board appointed Brigadier General Theophilus Holmes "Commander of the Coast Defenses of the State" (Ashe 1971; Hill 1926; King 1902). At the time of Holmes' appointment, North Carolina did not have a standing, well-trained, organized, state militia. To remedy the troop problem, the State Legislature passed an act on 1 May that authorized Governor Ellis to raise ten regiments of State Troops who enlisted for 3 years of war service. The only notable military action of the Civil War in the Sandhills was the Battle of Monroe's Crossroads. This skirmish is well documented and the battlefield location is precisely known. On 10 March 1865, three Confederate cavalry divisions attacked a large Union cavalry encampment that was part of General William T. Sherman's Army. Although the Confederates were eventually routed, both sides sustained significant losses. There are five known cemeteries containing Union dead from this battle; the majority of the Confederate dead were later exhumed and reburied in the cemetery at Long Street Church (Belew andScott 1997; Scott and Hunt 1997).

Although a limited system of railroad lines was constructed in the Sandhills before the Civil War, much of the railroad infrastructure was destroyed at the end of the war. In the decades after the war, the railroads slowly returned to the region. In an effort to seek out and develop new markets, railroad companies reportedly sent agricultural and industrial specialists into the Sandhills to evaluate the social, economic, and environmental conditions. Entrepreneurs soon followed to construct health spas, sanitariums, and resorts (Haynes 1916). A comprehensive railroad network rapidly developed between 1870 and 1900 and formerly remote communities were soon directly interlinked with regional urban centers such as Fayetteville, Raleigh, and Wilmington. As the railroad system flourished and the naval stores industry declined in the last decades of the nineteenth century, the frequency of steamboat runs on the Cape Fear waned dramatically (Evens 1967; J ohnson 1977).

The majority of the historic sites identified on Fort Bragg properties are from the post-Civil War era. Site data indicate that Reconstruction era building practices largely mirrored those of the late antebellum period. Plank-on-frame construction was the most prevalent method of house construction, but log or split timber houses and agricultural buildings were still built in the rural areas of the Sandhills after the turn of the twentieth century (Idol 1999). 


\section{Development of Fort Bragg: 1918-Present*}

In April 1917 the United States entered World War I, which had been devastating Europe since August 1914. The Army established Camp Bragg during a second round of WWI post openings, when specialized training camps were set up (Cannan 1995). In late 1917, a scout for the U.S. Army began searching for land that would house a new field artillery range and camp; one of the sites visited was the Fayetteville, N.C. area. In J une 1918, an investigative team was sent from Washington with the following site parameters: a location in the northern area of the southeastern United States where the climate permitted year-round training, level topography, adequate water supply, access to railroad lines, and land that was not productive farmland. When the team arrived in the Sandhills section of North Carolina's coastal plain, they found an ideal site and began to lease the land for the camp. The new camp was named Camp Bragg in honor of General Braxton Bragg, of Warrenton, NC, a captain in the Mexican War and subsequently a general in the Confederate Army (Figure 6).

The original master plan of Camp Bragg was prepared in 1918 by Lieutenant Colonel D.H. Sawner of the U.S. Army Quartermaster Corps, C.F. Pilat, camp planner, and J.E. Sirrine, supervising engineer (North Carolina Collection 1919, p 13). Pilat and Sirrine were local Camp Bragg personnel, while Sawner was at the Quartermaster Corps Office in Washington. The 1918 plan of Camp Bragg by Sawner, Pilat, and Sirrine was a dramatic neoclassical Beaux-Arts plan, which Fort Bragg still reflects today.

Camp Bragg was officially established on 4 September 1918. Leases were obtained on approximately 50,000 acres of land and a few days later on 18 September 1918, an army of ditch-diggers and carpenters began to build roads, water and waste systems, and hundreds of wooden buildings at a total cost of \$7 million (North Carolina Collection 1919, pp 15-17).

\footnotetext{
* The historic context of Fort Bragg is synthesized from these main sources, unless noted: Parker 1990, pp 114-117, 133-138; North Carolina Collection 1919; Acofs, Headquarters, Fort Bragg 1967; Office of Public Relations, Fort Bragg 1941 (hereafter referred to as "History 1967").
} 


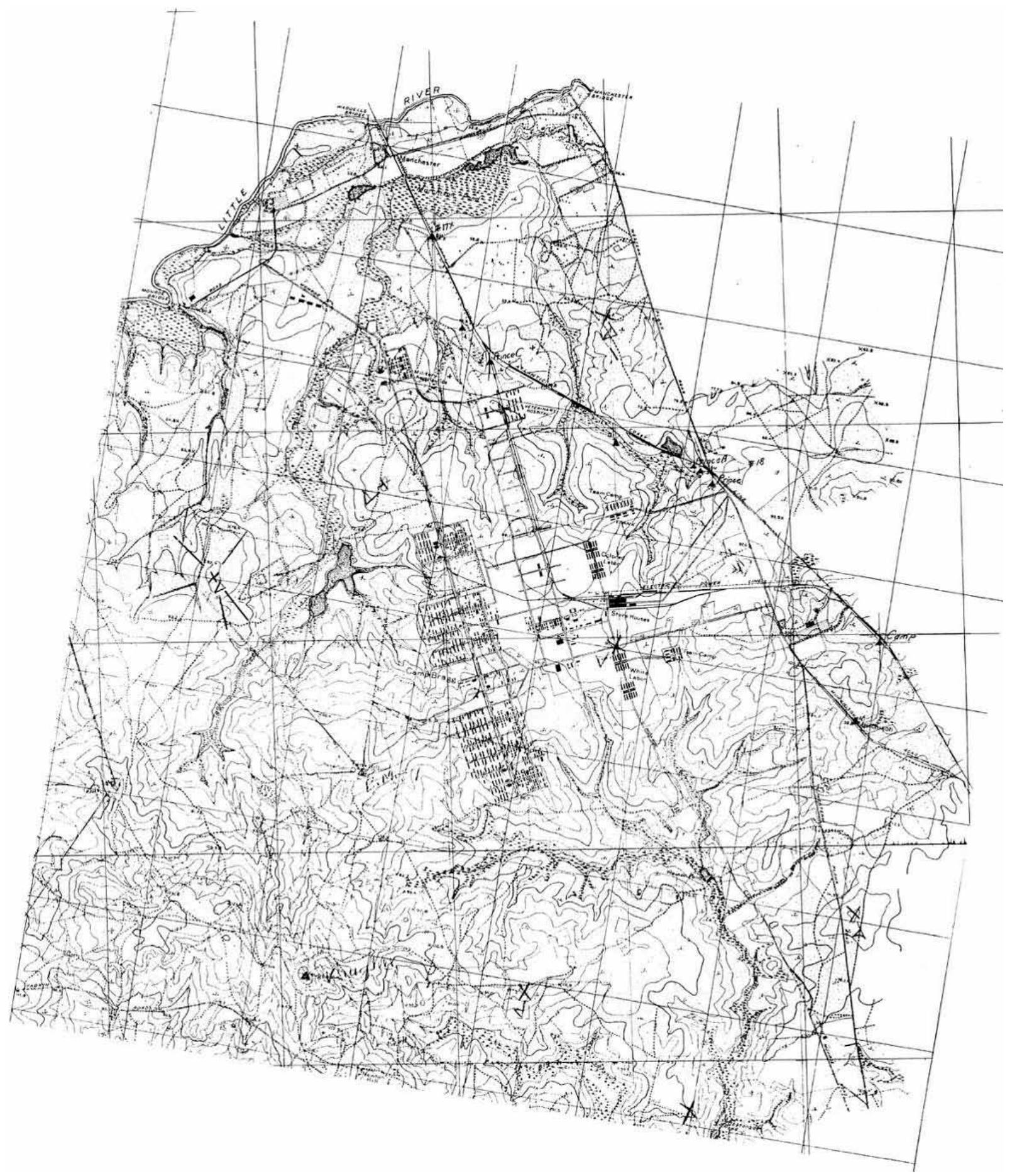

Figure 6. 1918-1919 Map of Camp Bragg (Fort Bragg Cultural Resources).

The wood-framed buildings were meant to be temporary and to provide only basic accommodations. Seven months later in the spring of 1919, the camp was ready to accommodate 16,000 soldiers. However, the war ended on 11 November 1918 and the new quarters remained unoccupied during wartime. The Army intended the camp to become a permanent artillery 
post, and stationed 1200 troops there in 1919 and 1920. In 1921, the government began buying the leases to the land ultimately paying almost $\$ 1$ million for 50,711 acres.

The original plan established a north-south axis that organized the rest of the camp; the main axes were Randolph Street running east and west and Reilly Road running north and south. The Beaux Arts plan incorporated City Beautiful ideas, which established that cities should have wide avenues and open spaces. Camp Bragg planners laid out a pattern of streets parallel to Reilly Road allowing for broad avenues and parks. In this way, the "civic center" of the camp was established just east of Reilly Road. In this area were the parade ground, officers' quarters, a temporary officers' club, and the golf course. This cluster of spaces was bisected by Randolph Street, which was the east-west organizing axis through the site (North Carolina Collection 1919, p 13). The original Camp Bragg plan had two main types of organization: the linear configuration set along axial streets, and the U-shaped promenade used to organize the housing districts.

Fort Bragg between the Wars: 1922-1939

After the war, all of the 40-some WWI cantonments in the United States were neglected and fell into disrepair. In August 1921, the War Department decided to close Camp Bragg, along with many other temporary WWI cantonments. Camp Commander Brigadier General Albert J . Bowley was convinced that the camp was too valuable as a training post to abandon and began to lobby influential politicians to keep it open (Little 2001, $\mathrm{p} 13)$. This led to the Secretary of War, J ohn W. Weeks, coming for an inspection visit; as a result, in September 1921, the abandonment orders were revoked. However, this only made Camp Bragg a permanent camp, not a permanent post, which left it vulnerable to closure. Construction on a rail line (see Figure 7) was started in 1921 that would run from the nearby town of Fayetteville, improving accessibility to the camp. Because Camp Bragg was the only reservation in the United States large enough for longrange artillery weapons testing, the Field Artillery Board, an agency devoted to researching and testing new artillery weapons, was transferred to Camp Bragg from Fort Sill, OK in February 1922. 


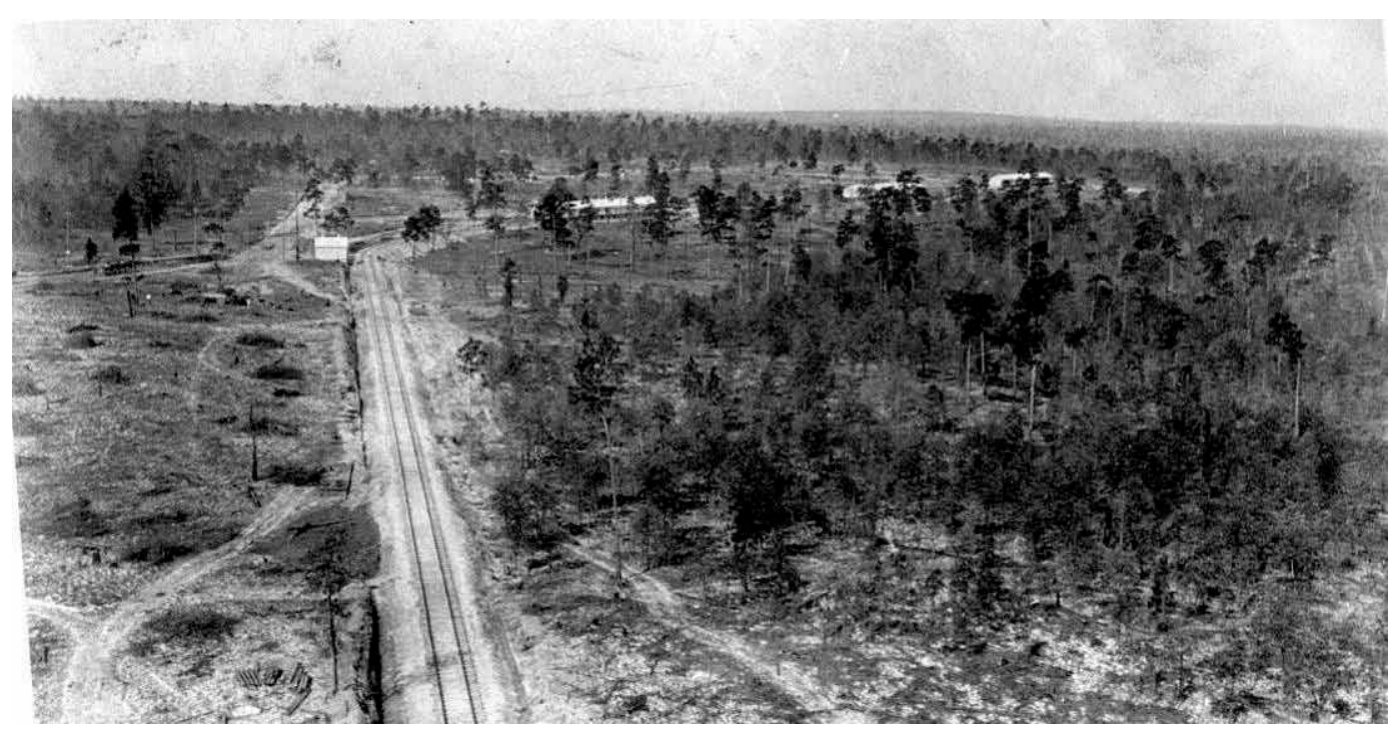

Figure 7. Camp Bragg rail line; magazines, Pender Street, undated (Fort Bragg Cultural Resources).

In April 1922, the War Department established the installation as a permanent post, and on 30 September 1922, Camp Bragg became Fort Bragg. By 1922, the post had a total acreage of 120,211 acres (see Figure 8). The mid-1920s were years of valuable training for artillery regiments, with the Field Artillery Board making Fort Bragg a laboratory of experimentation in types of vehicles, weapons, and equipment. Figure 9 shows an aerial photograph of Camp Bragg during this period.

Fort Bragg was one of five WWI temporary cantonments to be authorized for conversion into permanent school and home posts for the five branches of the Army. These posts were Fort Benning, GA (Infantry); Fort Belvoir, VA (Engineers); Fort Monmouth, NJ (Signal Corps); Fort Eustis, VA (Railway Artillery); and Fort Bragg (Field Artillery, east of the Mississippi) (Ray 1994, p 9). A number of other posts were also improved during these years, including Fort Knox, KY; Fort Devens, MA; Fort Lewis, WA; Fort McClellan, AL; and Fort Sam Houston, TX (Grandine 1993, p 4).

In 1925, the Secretary of War noted in his Annual Report that the problem of providing adequate shelter was the gravest challenge of the War Department, and the officers dreaded fire in the temporary wooden barracks and hospitals. In an effort to address these problems, Congress enacted Public Law 45 in 1926 authorizing the Secretary of War to dispose of 43 military reservations and create a "Military Post Construction Fund" to finance housing and hospital needs. A year later, Fort Bragg was one of the first recipients when the first $\$ 7$ million became available. 


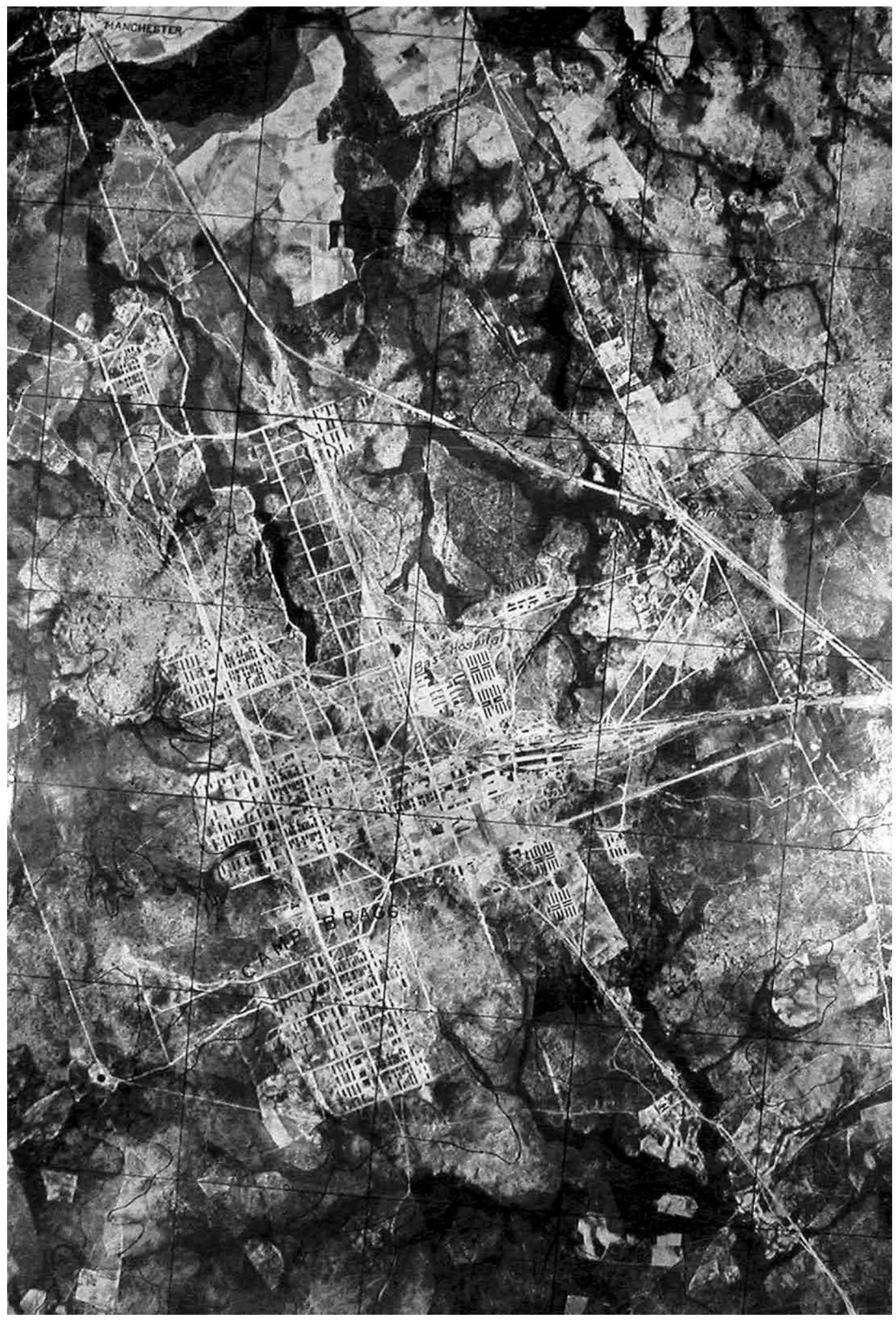

Figure 8. Aerial view of Camp Bragg, 1920s (Fort Bragg Cultural Resources). 


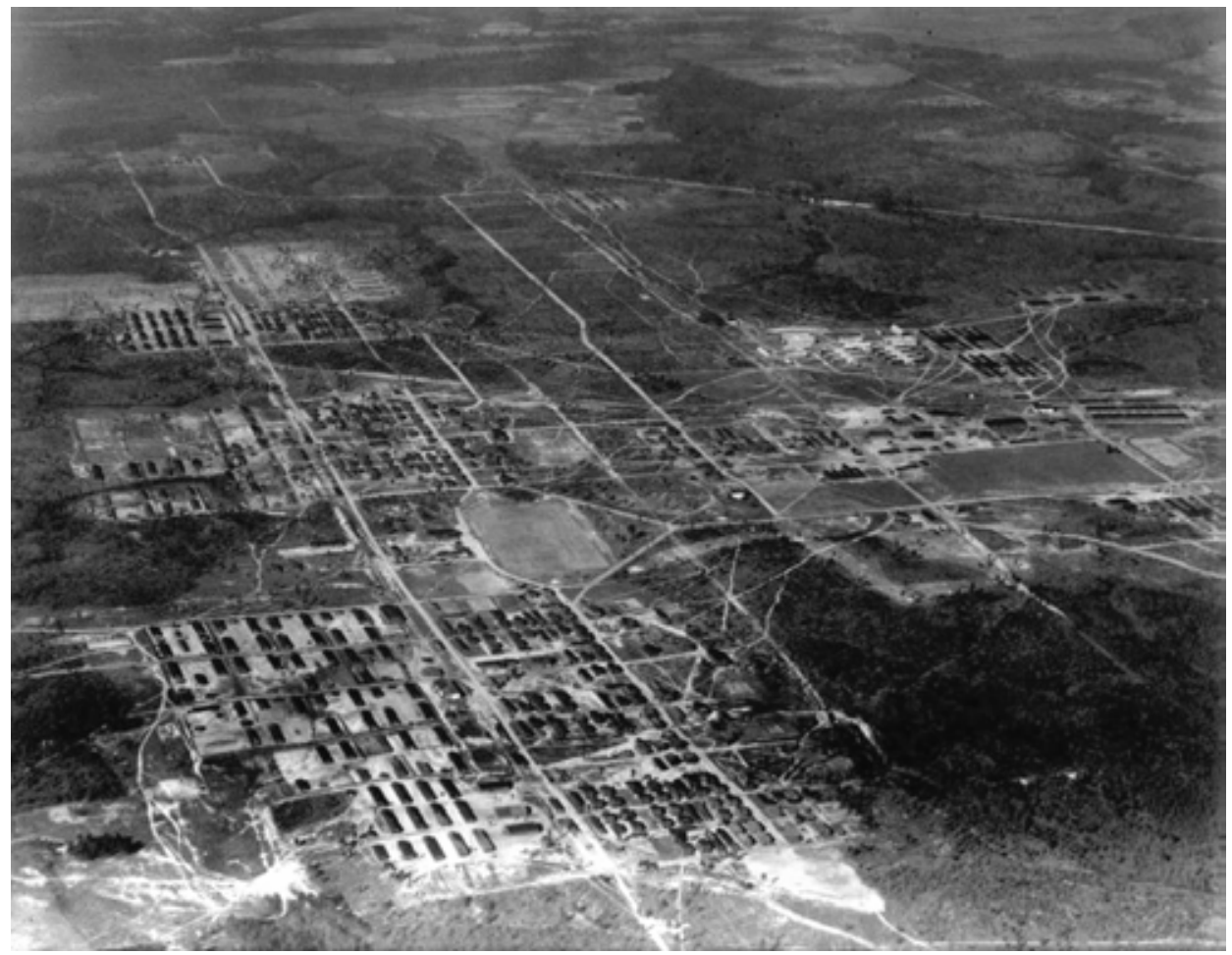

Figure 9. Aerial view of Camp Bragg 1924 (National Archives and Records Administration [NARA] College Park RG342-FH, box 1060, photo B17355).

The five WWI posts, which were substantially designed or redesigned by the Quartermaster Corps in the 1920s and 1930s, have a unique architectural unity, as they evolved over a short period of time, unlike most posts that grew over nearly a century (Ray 1994, p 231). At this time, the Quartermaster Corps, which oversaw planning, design, and construction of permanent facilities, switched from a single-building emphasis to the planning of overall installations. Military posts were self-contained communities and were the products of a large-scale planning effort to illustrate contemporary planning theories. The Quartermaster Corps gave each existing post a complete study to develop an overall post design that would plan for the addition of all required permanent structures and to enable future expansion.

In 1926, the 1918 plan for Camp Bragg was reworked into a new master plan for the permanent post (Figure 10). The planners, consisting of the Quartermaster Corps, Camp Commander Brigadier General Albert J . Bowley, and consulting planner George B. Ford, retained the original civic center containing the parade ground and axial street plan, and planned permanent buildings on the sites of the temporary frame WWI buildings. 


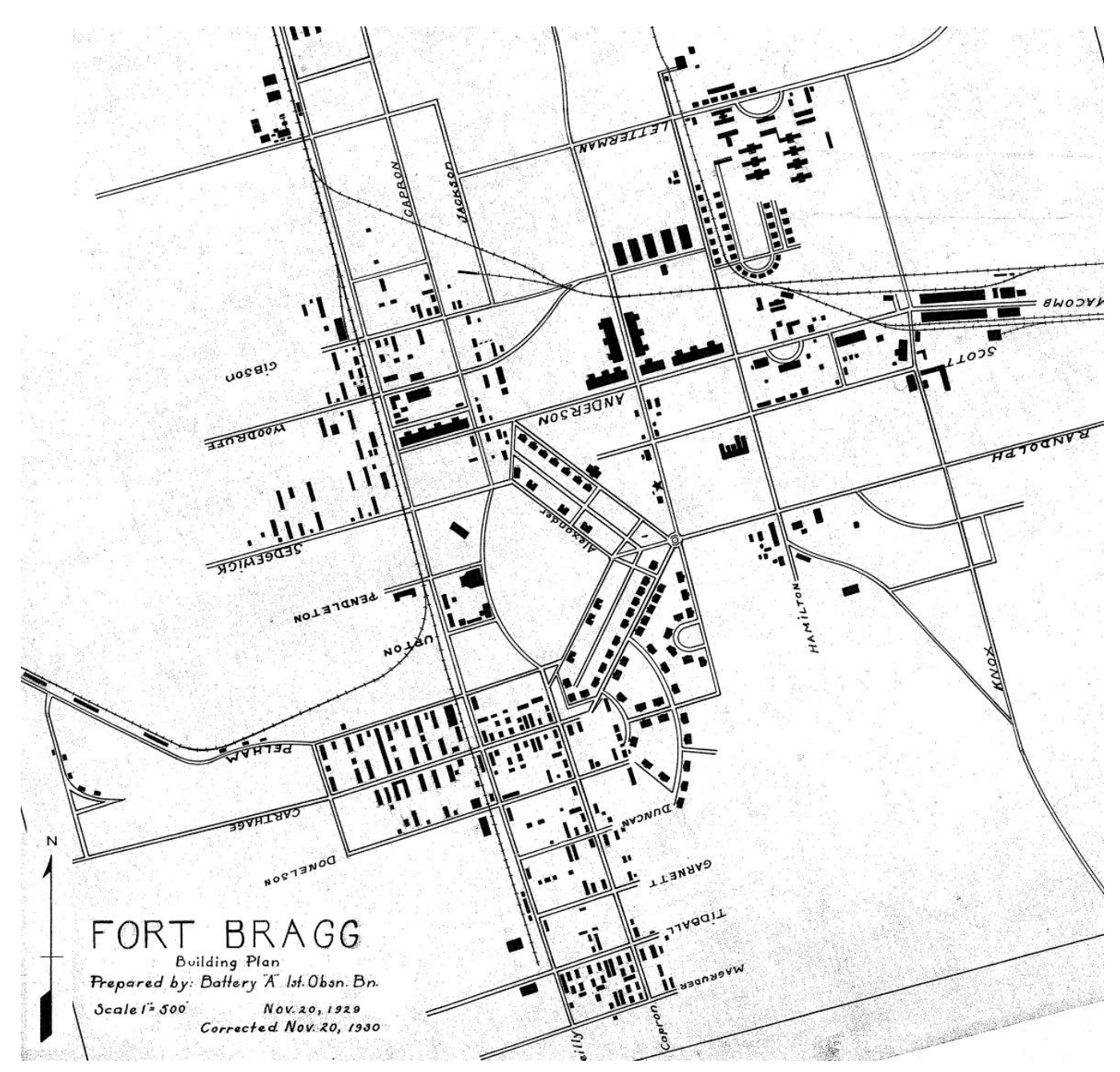

Figure 10. Building plan of Fort Bragg, 1930 (Fort Bragg Cultural Resources).

First Lieutenant Howard B. Nurse, chief of the design branch of the Quartermaster Corps, was called to create "one great social organization" at Fort Bragg, which would provide healthful conditions, positive social interaction, and proper soldier training. In his plans, Nurse advocated careful consideration of the local topography, distinctions between main thoroughfares and secondary streets, and grouped buildings. The result is a skillful composition of open spaces, recreational areas, and landscaping emphasizing military ideals of order and hierarchy (Nurse 1928, pp 14-16).

These ideas were integral to the redesign of Fort Bragg and George B. Ford, city planning advisor to the War Department stated the new post was to have "all the charm that the best modern subdivisions have and yet at the same time the new field should function with great efficiency" (Ford 1909, p 20). He advocated post plans that presented pleasing "mosaics" or patterns from the air, with a combination of formal areas and informal 
areas, Officers' quarters arranged in charming subdivisions adjoining recreational facilities, garages grouped along rear alleys, crescent-shaped parade grounds with the chapel at one end and administration buildings at the other, and service buildings grouped along the periphery. By the late 1920s, parade grounds served as landscape elements within the overall master plan. Often boulevards and vistas linked multiple parade grounds, serving different functions.

Older posts presented numerous problems of integrating existing buildings with new buildings. In a 1926 hearing before the U.S. Congressional Committee on Military Affairs, Quartermaster General Cheatham stated that the first step was to develop a plan with "complete layouts to the last buildings" for each post (Cheatham 1926, pp 23-25).

The design of the November 1926 proposed post plan for Fort Bragg was a collaboration between Brigadier General Bowley and the Quartermaster Corps. The administrative focus of the cantonment was shifted to the intersection of Armistead and Macomb Streets, while the barracks were arranged linearly along Macomb and Armistead Streets. Ford developed the plan designating the chevron near the parade field to be officers' quarters incorporating open plazas. The plazas were to emphasize the suburban qualities in the Normandy Heights neighborhood. The Quartermaster Compound, with guardhouse, bakery, and warehouses, is shown in its present location at the eastern edge of the main post along the railroad tracks. The 1929 plan, updated in 1931, shows modifications to the plan made in 1928 and early 1929 to incorporate revisions that were being made as construction continued. This plan showed the additional Officers' housing set with a plaza south of the parade ground and the location of the new hospital on Macomb Street. Another change was the addition of the Bastogne Gables non-commissioned officer (NCO) housing set around a plaza at the northeast corner of the main post (site of the old WWI hospital area). Between 1928 and 1930, all occupied temporary buildings from the WWI building period were painted and most of the unoccupied ones were torn down.

The first phase of permanent construction, which took place from 1927 to 1931, consisted of a number of three-story barracks, one- and two-story Officers' housing in Normandy Heights, and one-story NCO housing in Bastogne Gables. The end of 1931 saw over $\$ 3$ million spent on permanent construction at Fort Bragg (Figure 11). 


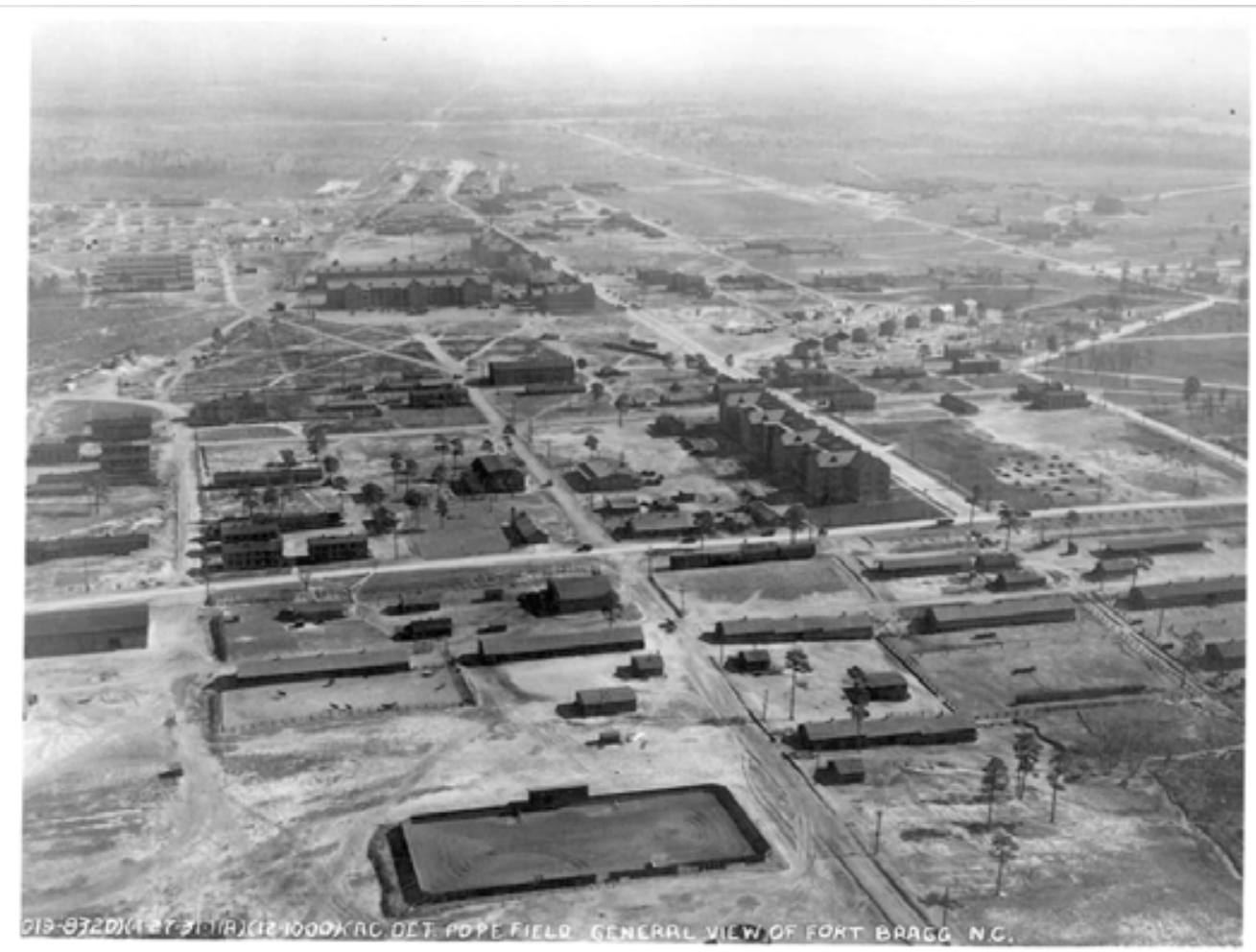

Figure 11. 1931 Aerial view of Fort Bragg looking southeast (Fort Bragg Cultural Resources).

A map, dated 1 February 1935, indicates completed new construction, proposed new construction, and temporary construction on Fort Bragg. Thus, the 1926 main post plan underwent constant refinement during construction (Figure 12). In 1934, the Post Headquarters (1-1333) was built opposite the Post Hospital (1-1326) on Macomb Street, and the Post Chapel (11510) was built facing the parade field (Figure 13).

In 1938 Congress approved a million-dollar building appropriation for Fort Bragg. From 1934 to 1940 construction of barracks, Officers' housing (Figure 14), and NCO housing continued along with major public buildings such as the Theatre (1-1202), Federal Artillery Board (1-1554), Post Ordnance Shops (2-1549), Commissary (2-1256), Quartermaster Office (21148), Guard House (2-1143) and Signal (telephone) Offices (2-1114). Necessary industrial and infrastructure construction progressed, including ammunition magazines, motor and material sheds, a modern water supply system with cast iron mains, and storm and sanitary sewers. 


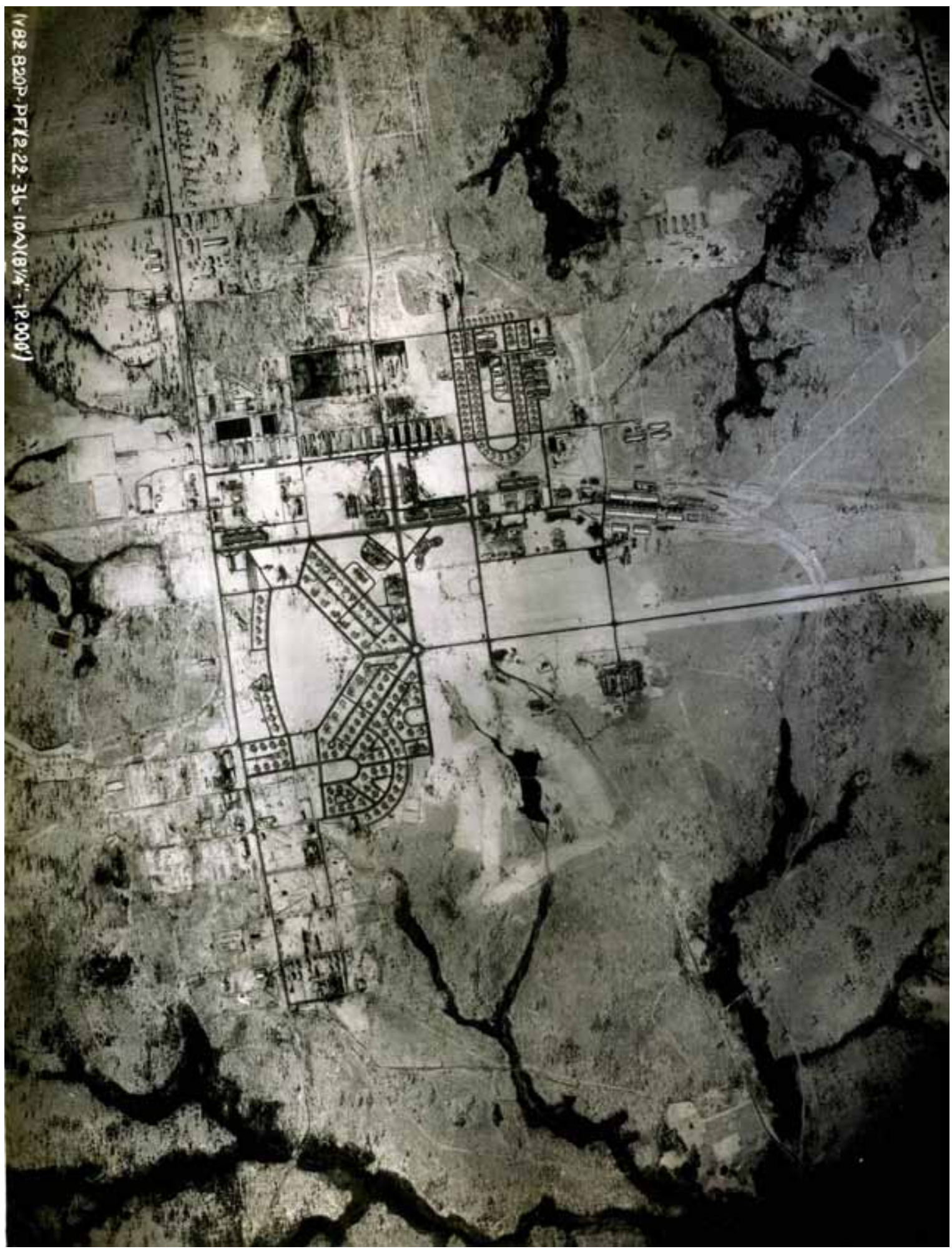

Figure 12. Aerial view of Fort Bragg, 1936 (Fort Bragg Cultural Resources). 


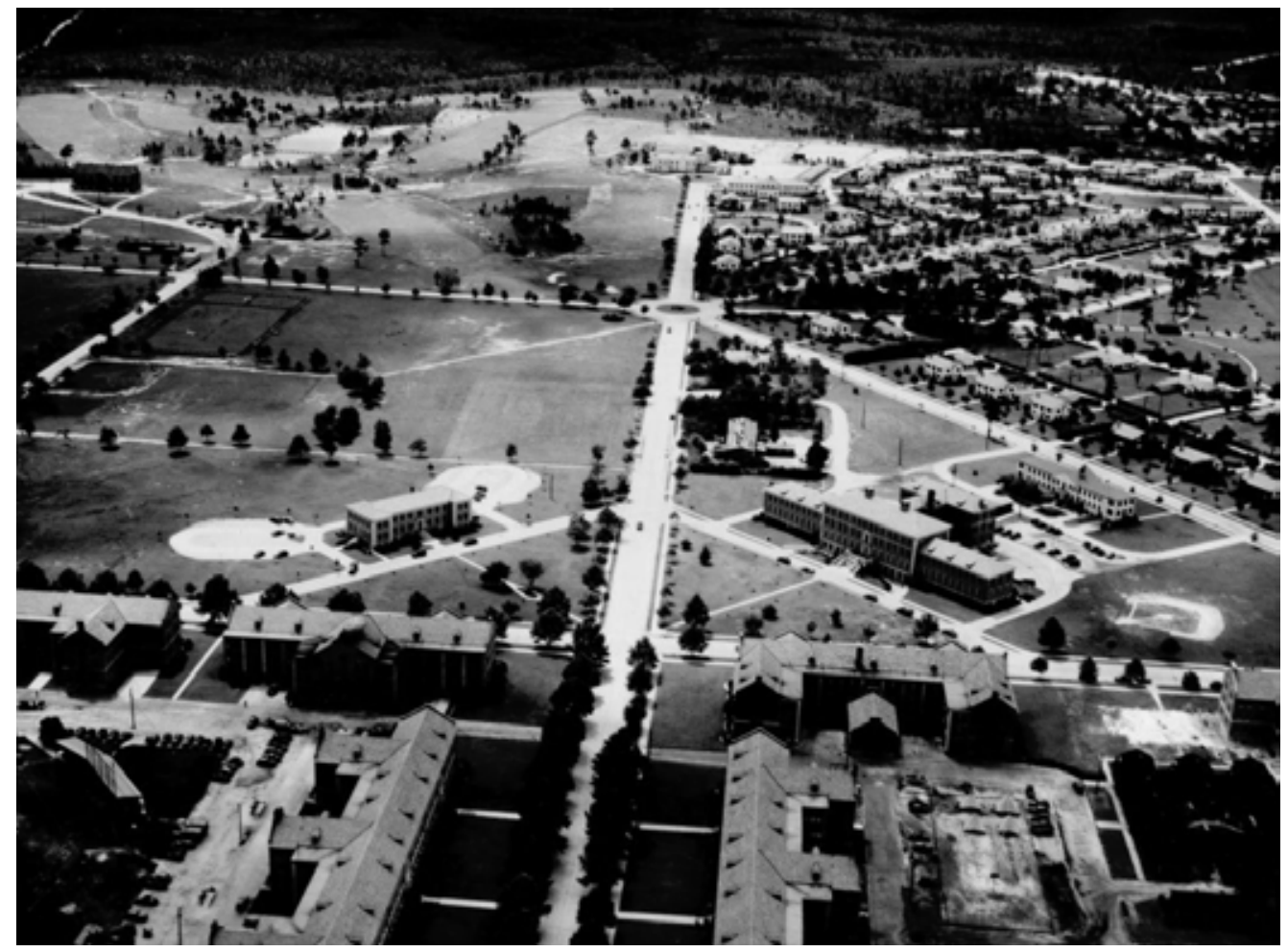

Figure 13. Post Headquarters (Building 1-1333) on left with Post Hospital (1-1326) in 1939 (NARA College Park RG342-FH, box 1060, B17347).

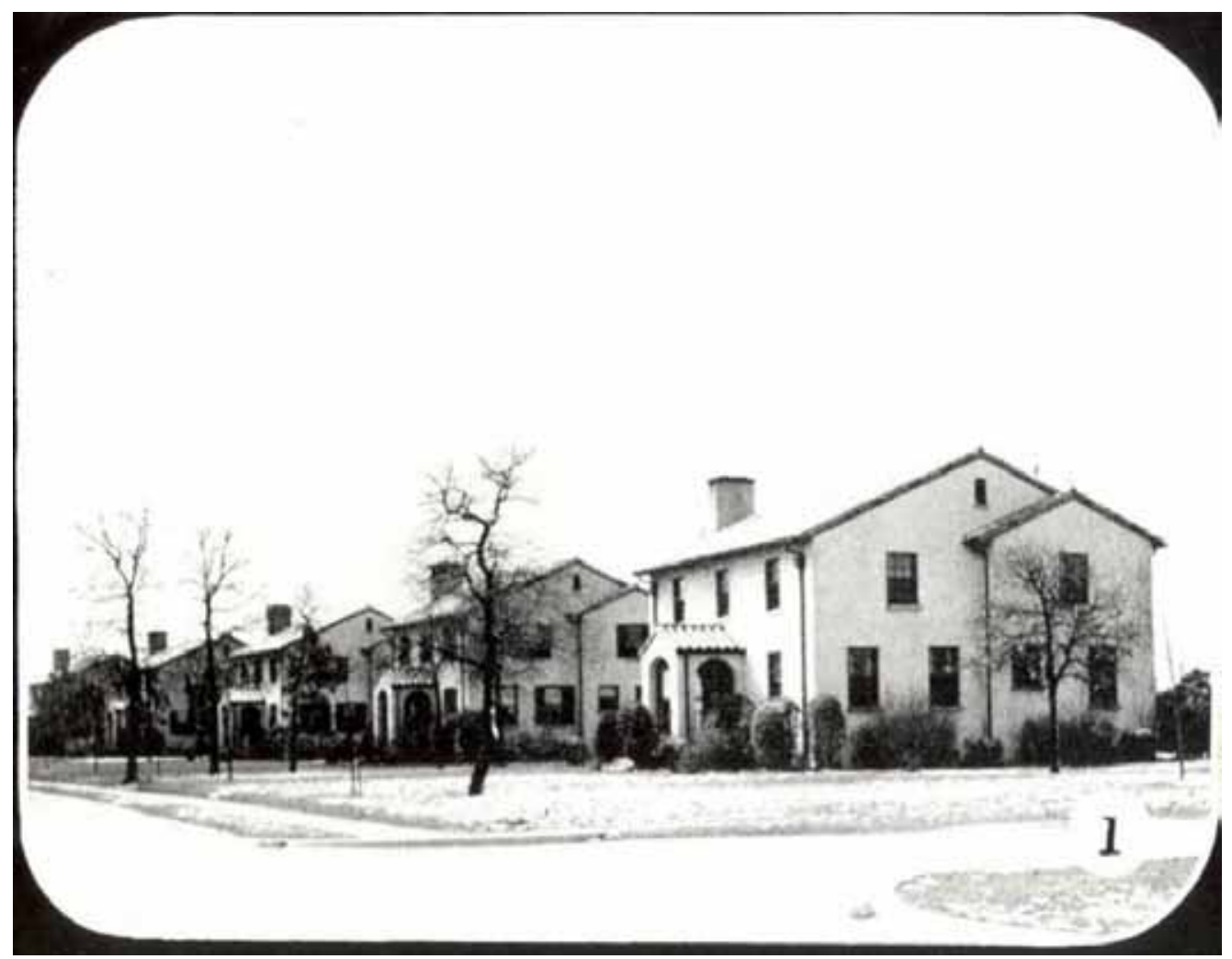

Figure 14. Normandy Heights officers' housing, 1941 (Fort Bragg Cultural Resources). 
Fort Bragg during World War II: 1940-1945

The Defense Preparation Program for World War II took place from September 1940 to August 1941. This building program resulted from the increasing aggression of the fascist governments in Europe, which accelerated Fort Bragg's activity. Involvement in a world war appeared inevitable and Fort Bragg assumed a leading role in preparations for war (Army Navy Register 1941). At this time, Fort Bragg was the largest field artillery range in the country and the expansion of the post for WWII involved a construction force of some 31,000 men, a daily payroll over $\$ 100,000$, and lumber supplied by some 700 lumber mills. By August 1941, the expansion was largely complete, with 2739 buildings constructed at a cost of $\$ 44$ million, making Fort Bragg North Carolina's third largest city (Figure 15) (Office of Public Relations, Fort Bragg 1941). The Constructing Quartermaster at Fort Bragg in 1940-1941 was Lawrence Lee Simpson, who had been involved in construction of some of the permanent buildings on the post in the 1930s (Fort Bragg Public Works and Environment 1995).

An account written at the time reveals the feverish activity generated by the National Defense Program (Figure 16):

Seven days a week, twenty-four hours a day, thousands of men, most of who lived within a radius of 90 miles, worked steadily at the big program. Day and night huge trucks laden with building materials crept along the highways, which were already clogged by thousands of vehicles of every description. The two railroads that serviced the Post, the Cape Fear and the Atlantic Coast Line, delivered an average of 65 carloads of supplies daily. The timely procurement and delivery of building material contributed largely to the phenomenal speed with which the work was completed.

For nine months, the work of expanding Fort Bragg's housing facilities had continued unabated. Everywhere workmen were pushing roads through pine forests and, at one period during the project, buildings were erected at the rate of one building every 32 minutes. Sights of soldiers in training, carpenters working, guns and construction equipment, crowds, and general upheaval all presented a crazy patchwork of pictures. But there was method in this madness because, by August 19412739 new buildings were in use and several field units had progressed rapidly with the mobilization training. 


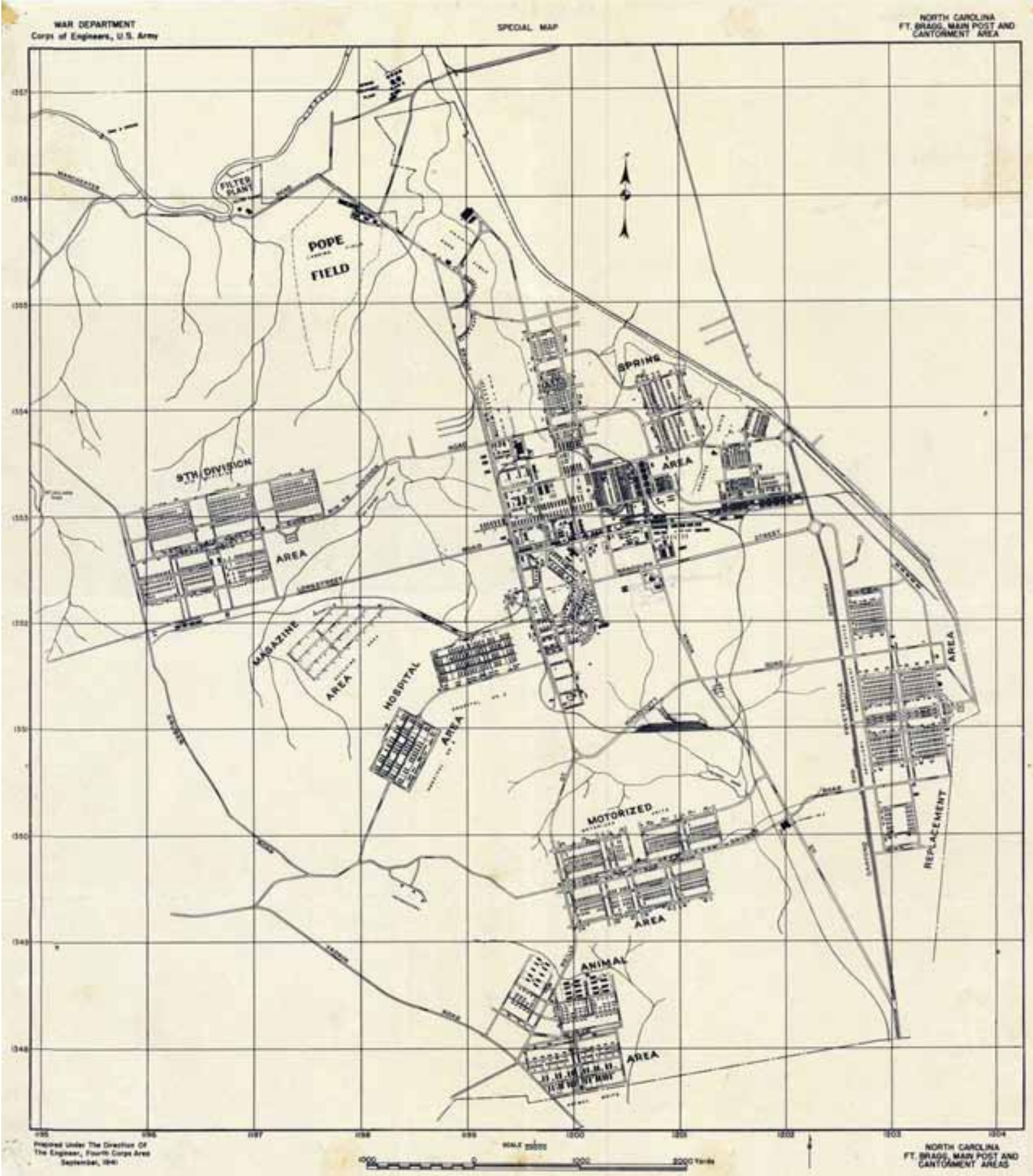

Figure 15. Main Post and Cantonment, September 1941 (Fort Bragg Cultural Resources). 


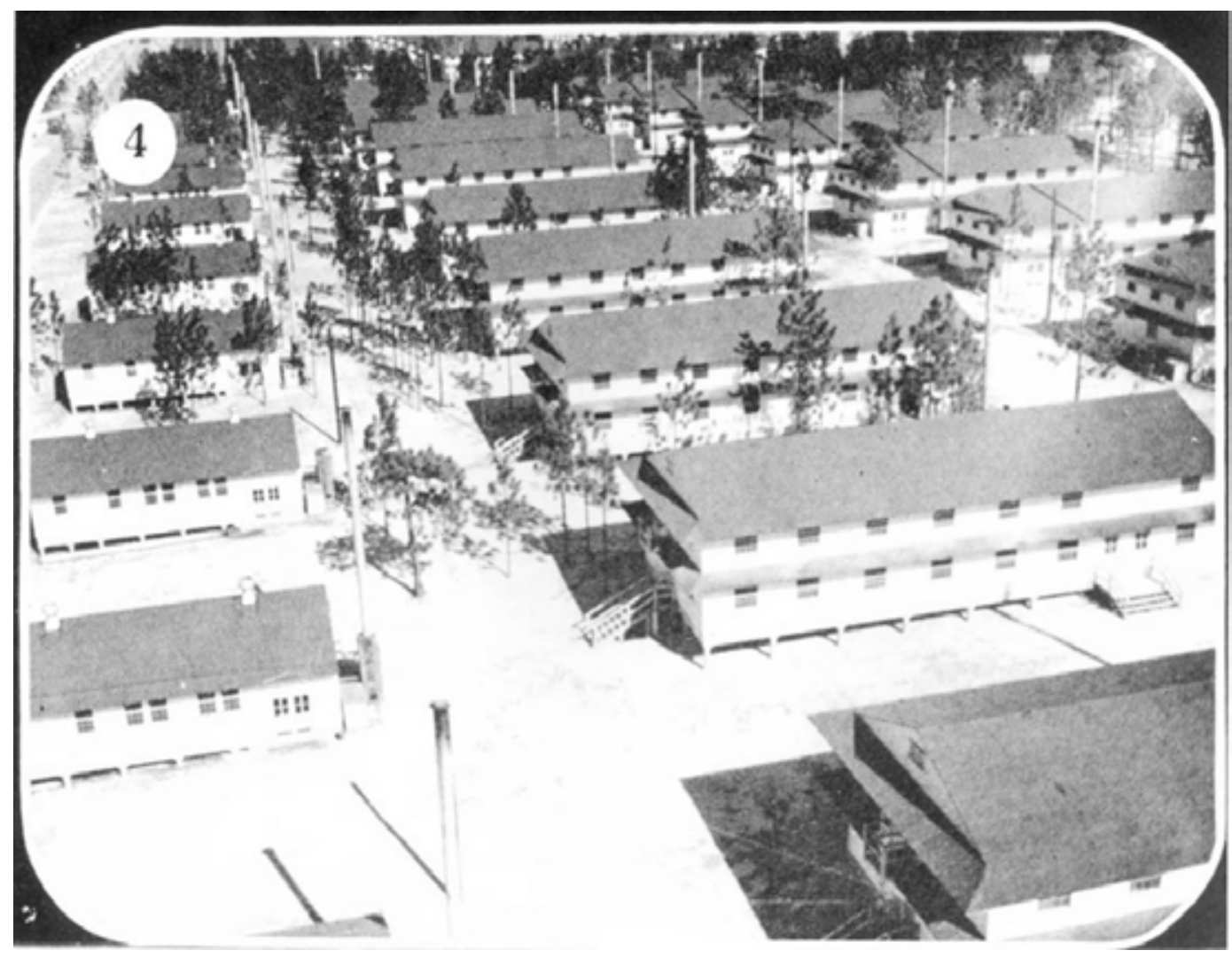

Figure 16. WMI temporary barracks (Fort Bragg Cultural Resources).

As of 1J anuary 1941, 20,000 personnel were stationed there. By J uly 1941, the personnel reached 67,000 men, making Fort Bragg the largest single encampment of soldiers in the United States. Fort Bragg's "fine rolling terrain, light sandy soil and moderate climate" made it the perfect location for tactical maneuvers and other training exercises during World War II. Over 300,000 men had been processed at Fort Bragg's induction center by the end of the war in 1945 (Army Navy Register 1941, p 6).

Post WWI Fort Bragg: 1946-1951

On 19 J anuary 1946, the 82nd Airborne Division returned from Europe and took up station at Fort Bragg. The 82 $2^{\text {nd }}$ Airborne established drop zones in the woodlands west of the cantonment area as it continued its training in the years following WWII.

A severe housing shortage plagued the United States and the U.S. Army after WWII. The Army placed trailer parks near Pope Field and converted a number of barracks to family housing. In recognition of this nationwide shortage, the U.S. Congress passed the Wherry Act of 1949 allocating 
funding for new family housing across the newly formed Department of Defense. The Wherry Act authorized construction of large housing areas at Anzio Acres and Corregidor Courts at Fort Bragg.

After the war Fort Bragg placed many of its buildings on stand-by status because the $82^{\text {nd }}$ Airborne was the only major unit stationed at the installation from 1946 until the outbreak of the Korean Conflict in 1950. The War Department placed the Headquarters V Corps at Fort Bragg in 1946. However, the Army did not send the $82^{\text {nd }}$ Airborne to Korea since both the Truman and Eisenhower administrations deemed it necessary to keep the $82^{\text {nd }}$ Airborne as a strategic reserve in the event of a Soviet ground attack anywhere in the world. Other changes in the post-war years were the Army reactivating the XVIII Airborne Corps on 21 May 1951 and then, in J uly 1951, they transferred Headquarters V Corps to Europe. Fort Bragg became widely known as the "Home of the Airborne" (History 1967, p 123).

\section{Fort Bragg: 1952-1960}

The XVIII Airborne Corps created Simmons Army Airfield in 1952 to handle airborne training since the newly created Pope Air Force Base already had a high volume of air traffic. The XVIII Airborne Corps constructed a 4000-ft runway, control tower, and needed hangars at the new airfield.

From 1946 to 1960, the Army spent almost \$63 million on various construction projects at Fort Bragg. The construction was largely to the west and southwest of the original cantonment, including 55 hammerhead barracks (Figure 17), bachelor officers' quarters, administration buildings, warehouses, chapels, post exchanges, dispensaries, a fire station, post office, and ammunition storage igloos. The Capehart Housing Act of 1955 authorized the construction of 1867 family housing units. Funding provided by the U.S. Department of Education authorized the construction of five elementary schools and one junior high school. The Army Medical Command completed the nine-story, 500-bed Womack Army Hospital in 1958 replacing the original cantonment hospital (Figure 18).

During the Cold War, Congress established specialized units that could conduct unconventional warfare operations behind enemy lines through Public Law 597 (Lodge Bill). The Army implemented Special Regulation 600-160-10 on 25 April 1952, and 2 months later, the $10^{\text {th }}$ Special Forces Group formed at Fort Bragg in a then remote area of the post called "Smoke Bomb Hill." 


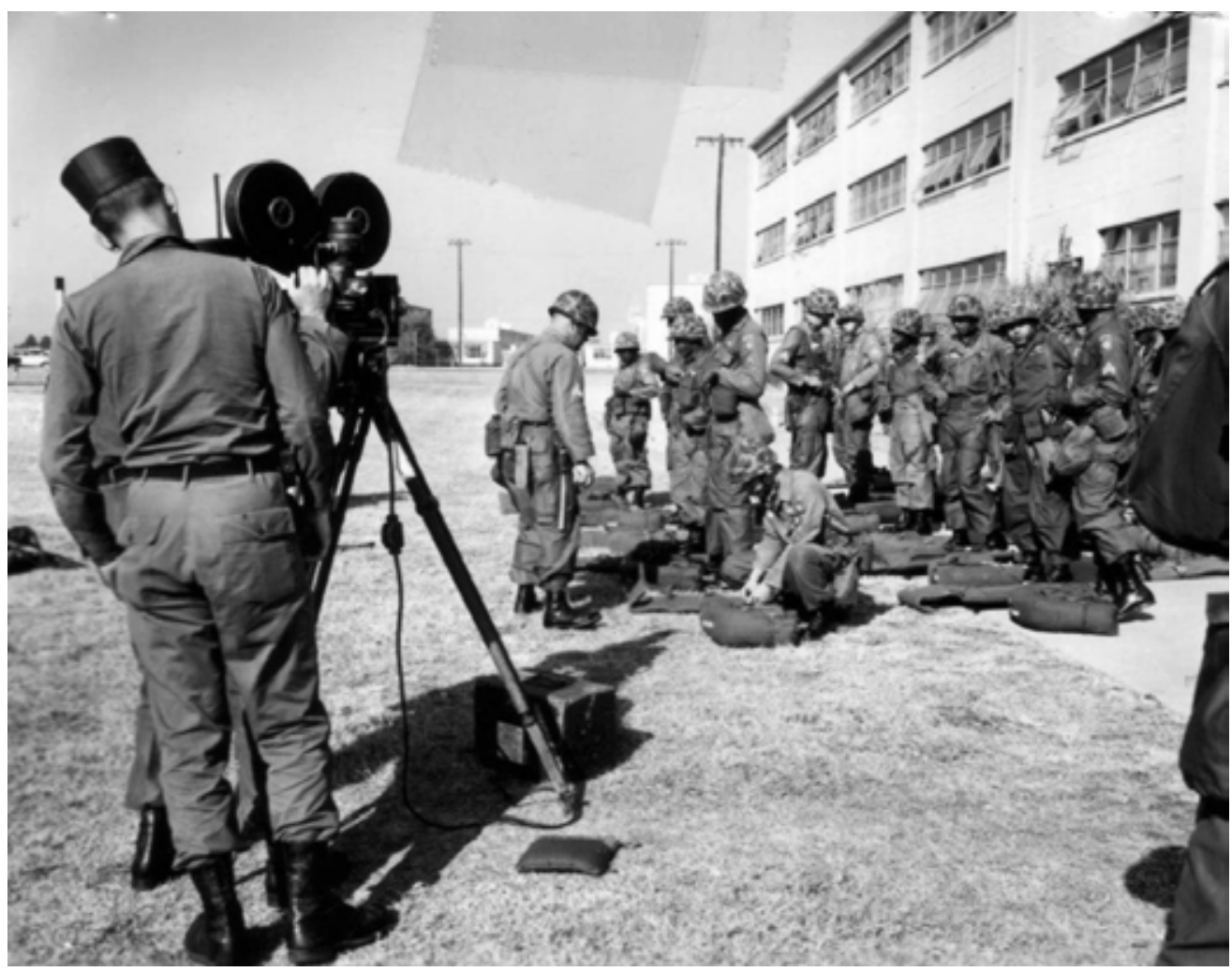

Figure 17. 2nd Platoon, Company B, 1st Airbome Battle Group, 503rd Infantry in front of a Fort Bragg hammerhead barrack in 1962 (NARA College Park RG111-SC 596852).

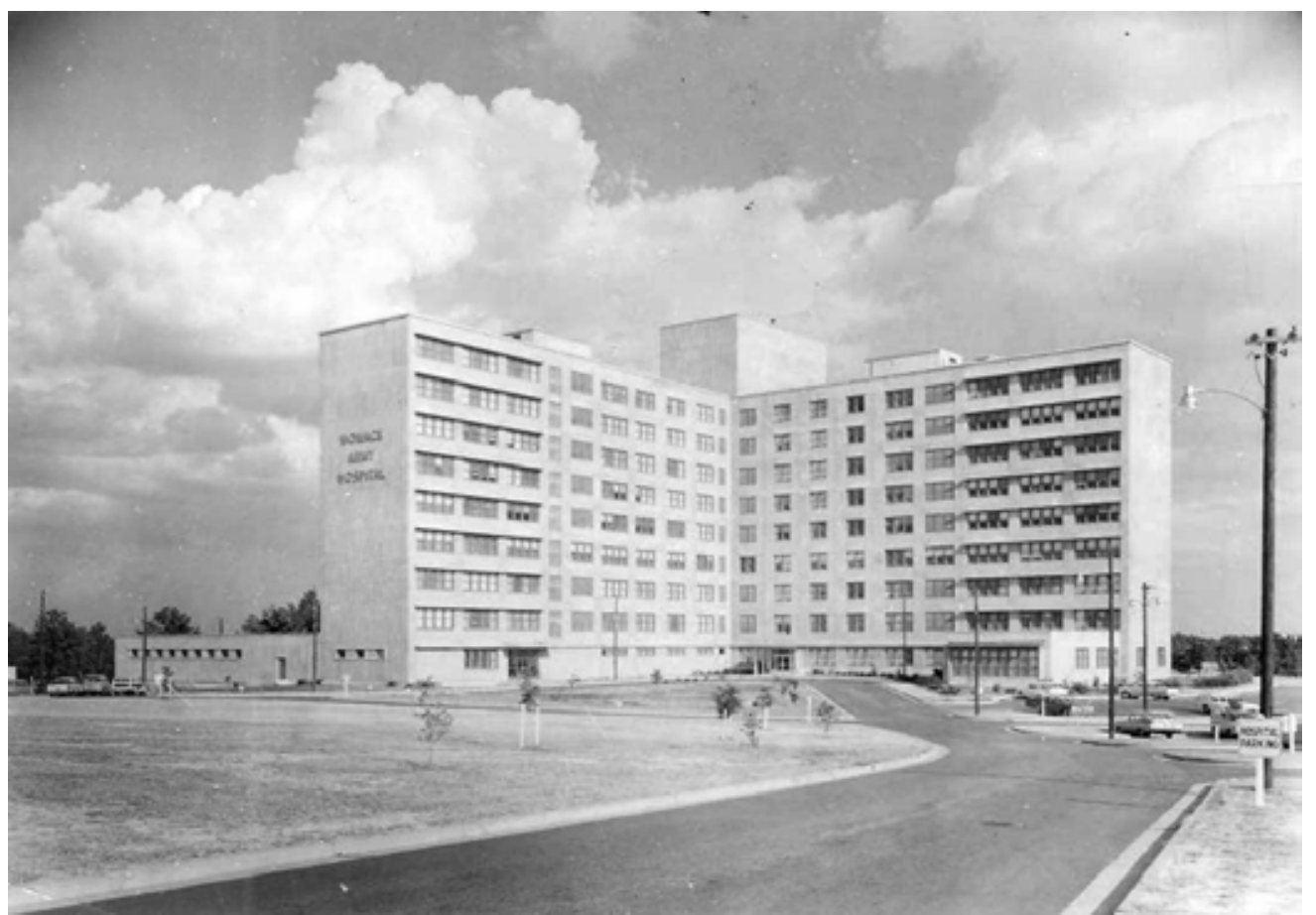

Figure 18. Womack Army Hospital in 1959 (NARA College Park RG111-SC 566029). 
The same year, the U.S. Army Psychological Warfare Center (renamed the U.S. Army Special Warfare School in 1956 and the U.S. Army Institute for Military Assistance in 1969) was established at Fort Bragg. In 1953, half of the $10^{\text {th }}$ Special Forces Group was permanently deployed to West Germany and the remaining half was redesignated as the $77^{\text {th }}$ Special Forces Group.

Fort Bragg: 1961-1975

Fort Bragg expanded again from 1961 to 1975. The XVIII Airborne Corps added to the facilities at Simmons Army Airfield, including another barracks area to the south of the 1950s hammerhead area, a NCO mess hall, bowling alleys, a gymnasium with a pool, and a youth center. The Capehart Program added more family housing to Fort Bragg. The Special Warfare School expanded into permanent facilities in 1965 with a headquarters and academic building, a chapel, two bachelor officers' quarters, a mess, and a central heating plant.

The role of the XVIII Airborne Corps and the 82nd Airborne remained largely the same during these years. The 82nd Airborne remained "on call" to respond to any threat anywhere in the world. In 1965, the 82nd Airborne was sent to the Dominican Republic to defend against a communist insurgency. In 1968 the 3rd Brigade was rushed to South Vietnam after the Tet offensive. The XVIII Airborne Corps and the 82nd Airborne continued to focus on training and combat readiness. This period also witnessed the emergence of the Special Forces as an intrinsic part of Fort Bragg. Figures 19-21 depict the OPHD at this time.

Fort Bragg: 1975 to the Present

From 1976 to 1989, the mission of the XVIII Airborne Corps and the 82 $2^{\text {nd }}$ Airborne continued to be that of a combat ready unit able to rapidly deploy as needed across the world. In 1983, the U.S. Army Institute for Military Assistance was renamed the U.S. Army J ohn F Kennedy Special Warfare Center and School and is currently under U.S. Army Special Operations Command (USASOC) and serves as the Army's special operations university. The 3rd Special Forces Group (Airborne) is currently stationed at Fort Bragg. Camp Mackall, first used as training grounds by Special Forces in 1952, is still in use for training today. Since the mid-1980s, several large land tracts in southern Harnett County, totaling some 20,000 acres, have been purchased by the U.S. Army to form Fort Bragg's Overhills and Northern Training Areas. 


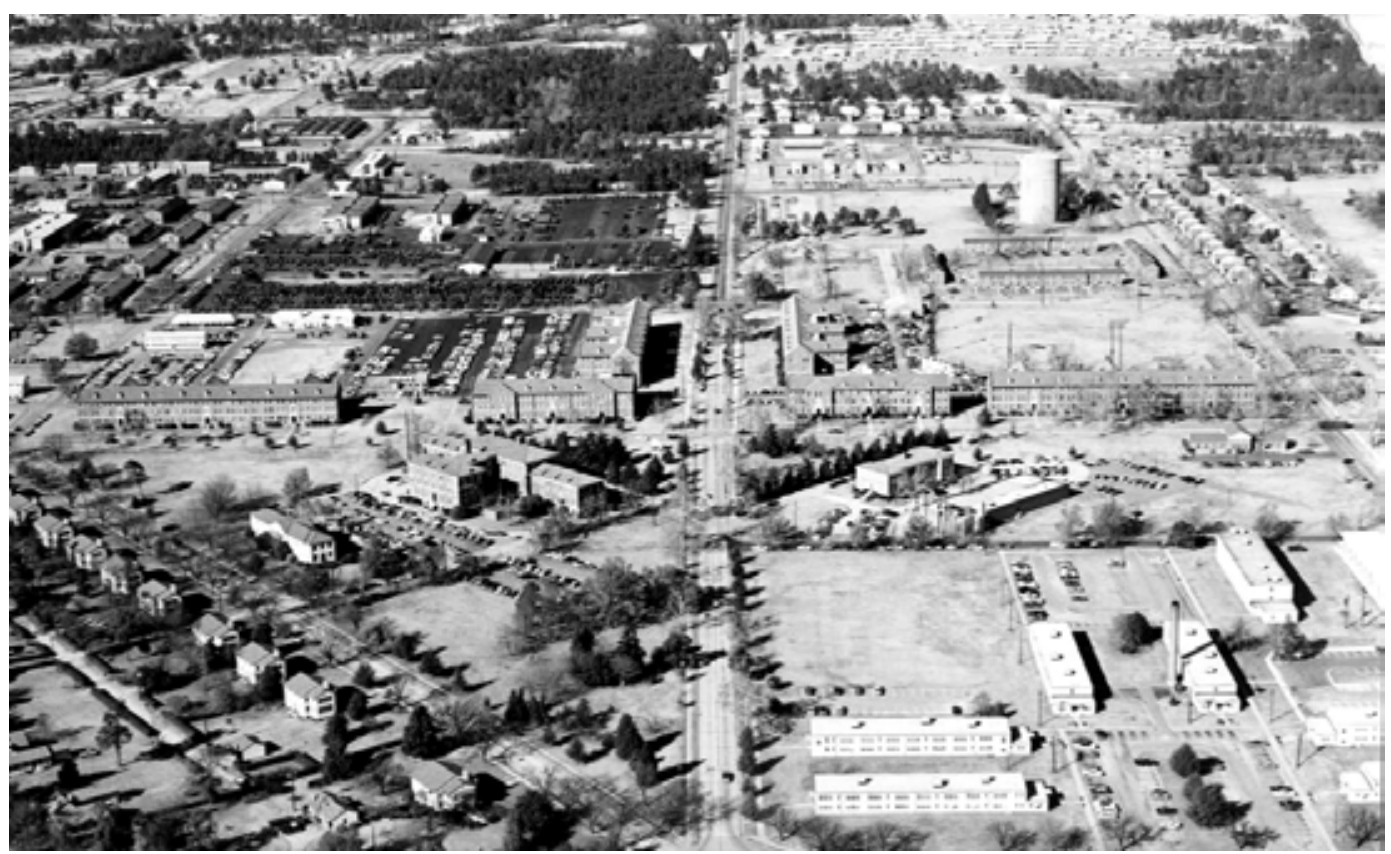

Figure 19. Aerial of the OPHD November 1968; looking north the old hospital is on the left with the administration building on the right (Fort Bragg Cultural Resources).

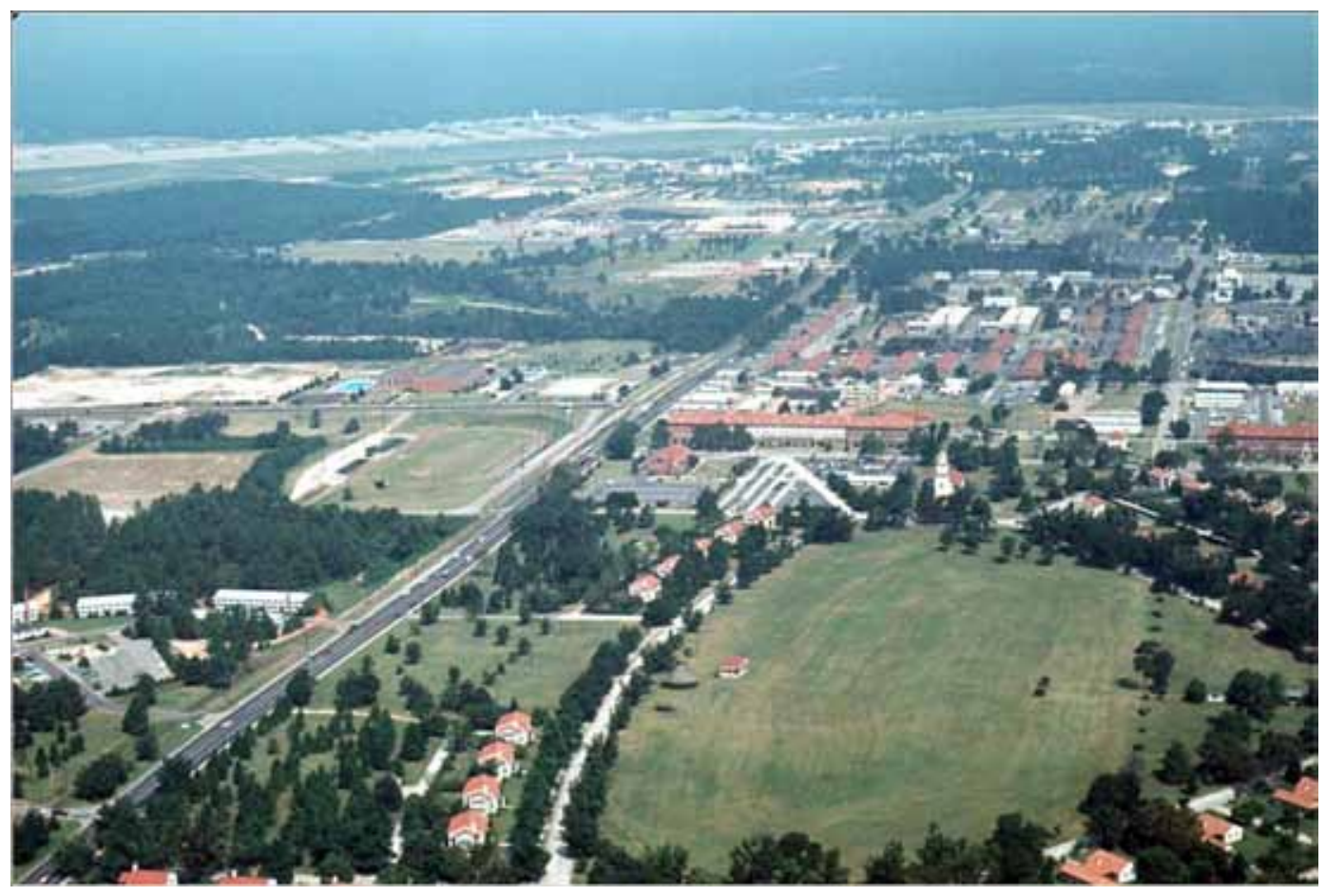

Figure 20. Aerial view of the OPHD looking north, 1969 (Fort Bragg Cultural Resources). 


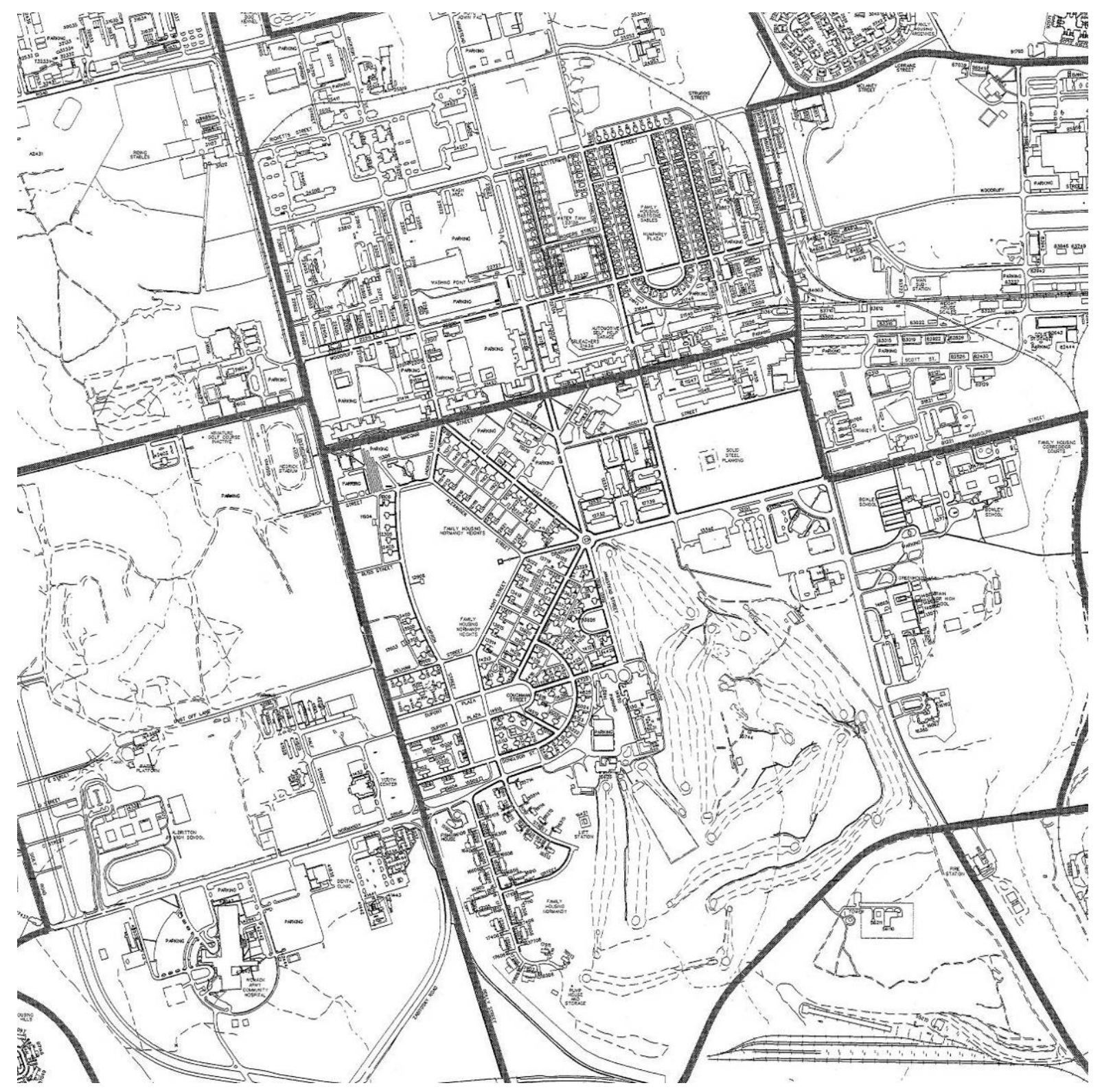

Figure 21. Map of OPHD, 1993 (Fort Bragg Cultural Resources). 


\section{Identification of Character-Defining Landscape Features}

The National Park Service defines landscape character-defining features as "a prominent or distinctive aspect, quality, or characteristic of a cultural landscape that contributes significantly to its physical character" (Birnbaum 1996, p 4). Through the study of landscapes the built environment is explained by the physical remains of the natural and cultural shaping forces. The landscape of Fort Bragg's OPHD is significant because it describes the adaptation of the built environment to the cultural values and mission of the military. Understanding the factors influencing and comprising the military landscape of Fort Bragg helps inform the preservation of its historic qualities. This chapter identifies the historically significant character-defining landscape features of the OPHD. These features are then used to evaluate the built environment and establish the historic eligibility of the area. Appendix A includes a list of landscape characteristics and features reinforcing the historical connections of the OPHD.

\section{Site and Layout}

The mission of the military determines land use and the spatial organization of the installation. The site for any installation is selected primarily based on the location's suitability for its mission. Implementation of the cantonment design incorporates the relationships between land use, circulation networks, and predominant environmental features (Loechl et al. 1996, p 67). The Sandhills region of North Carolina was selected for Camp Bragg's field artillery range because of the climate, level topography, access to rail lines, and because it was not productive farmland.

In WWI the Army developed a comprehensive set of standardized post layout plans and building designs. Camp organizations were created by choosing from standardized plans. These designs were simple and easily constructed and were based on grids with rows of uniform, tightly spaced buildings. Organizing the grid were roads separating one land use or unit from another. The buildings were wood framed and not built to last providing basic accommodations. The layout of Camp Bragg was adapted from standardized design plans in 1918 and 1919. The 1918 plan for Camp 
Bragg established a strong north-south axis of Reilly Road and east-west axis of Randolph Street that organized the rest of the camp. The original design planned for six brigades, but only two were constructed (Thompson 1919).

During the 1920s the military found that the WWI temporary construction was too dilapidated for continued use. The newly created "Military Post Construction Fund" enabled the construction of much needed housing and support buildings at Fort Bragg (Goodwin and Associates 1995, p 133). The Quartermaster Corps, led by Major General B. Frank Cheatham, was placed in charge of design and construction (Goodwin and Associates 1995). Teams of engineers, planners, architects, and landscape architects designed "efficient, cohesive, pleasant environment[s] with reasonable expenditures" (Goodwin and Associates 1995). Major General Cheatham assembled a distinguished staff of architects at the Quartermaster Corps, including First Lieutenant Howard B. Nurse. In addition, Cheatham consulted with civilian engineers, landscape architects, and city planners. One of the city planners consulted was also one of the first professional city planners, George B. Ford who reviewed and proposed post plans for functionality, aesthetic appearance, cost effectiveness, and appropriateness for climate and culture (Goodwin and Associates 1995).

The new urban planning concepts of the Garden City and City Beautiful movements were applied to redesigns of existing WWI cantonments. These movements were a product of the Beaux Arts approach to design that was transferred from France to the United States in the late nineteenth-century. Beaux Arts designs emphasized monumentality, symmetry, classical ornamentation, and hierarchy supporting civic institutions. Garden City and City Beautiful were reform movements in architecture and urban planning at the turn of the century, which sought to transform America's cities into safe, healthy, architecturally-impressive places. These ideas introduced broad avenues and parks into city organization as well as centralized civic spaces. "Beauty" was defined using proportion, harmony, symmetry, and scale, and promoted with images of gardens and parks, with street furniture and monumental buildings (Wilson 1989, p 79). The movements were also developed in part on Frederick Law Olmsted's work in the later part of the 19th century. In addition to aesthetic beauty, Olmsted attempted to incorporate the goal of "social order" into poor urban areas. New communities were planned around the social connections provided by cities yet combined with the pastoral qualities of the country. 
These ideas were integral to the redesign of Fort Bragg and other permanent Army posts in the 1930s.

The Construction Division of the Quartermasters Corps applied a functional, hierarchical arrangement of buildings, roadways, and open spaces to post planning. Uniform setbacks of buildings, curvilinear roads, building placement based on topography, and the use of boulevards and vistas to connect land uses were also applied. The Construction Division also created standardized plans featuring permanent barracks, family housing, and support buildings in regionally appropriate architectural styles. In the northeast, along the east coast and across to the northwest, a Georgian Revival was used and in the southeast and southwest Spanish Eclectic, or alternately named Spanish Mission Revival, or Spanish Colonial Revival (U.S. Army Corps of Engineers Seattle District 1997, pp 55-57). Located between these two zones, Fort Bragg has both building styles represented in its architecture.

First Lieutenant Nurse advocated using a comprehensive plan for installation growth based on principals such as increasing healthy conditions, scientific training of the troops, and the means for social interaction (U.S. Army Corps of Engineers Seattle District 1997, p 56). To achieve these goals, he recommended using design concepts such as cohesiveness, repetition of patterns, balance along an axis or radius, and the use of topography in design, layout, and street patterns (U.S. Army Corps of Engineers Seattle District 1997, p 56). Ford recommended using curvilinear roads, open spaces, and interesting vistas in contrast to the highly rectilinear layouts of the past. In addition, he recommended using architectural continuity, especially in residential neighborhoods, and abundant plantings (Figure 22). Ford noted in his 1909 essay The Technical Phases of City Planning that in residential areas "an open space should be left in the center of the block to serve as a playground for the children of that block" (Ford 1909) Although not visible in his 1926 plan for Fort Bragg, Ford's influence and ideals are clearly seen in the layout of Normandy Heights and Bastogne Gables around open spaces and parks. These U-shaped housing areas are a distinctive characteristic of the permanent layout of Fort Bragg (Figure 23). 


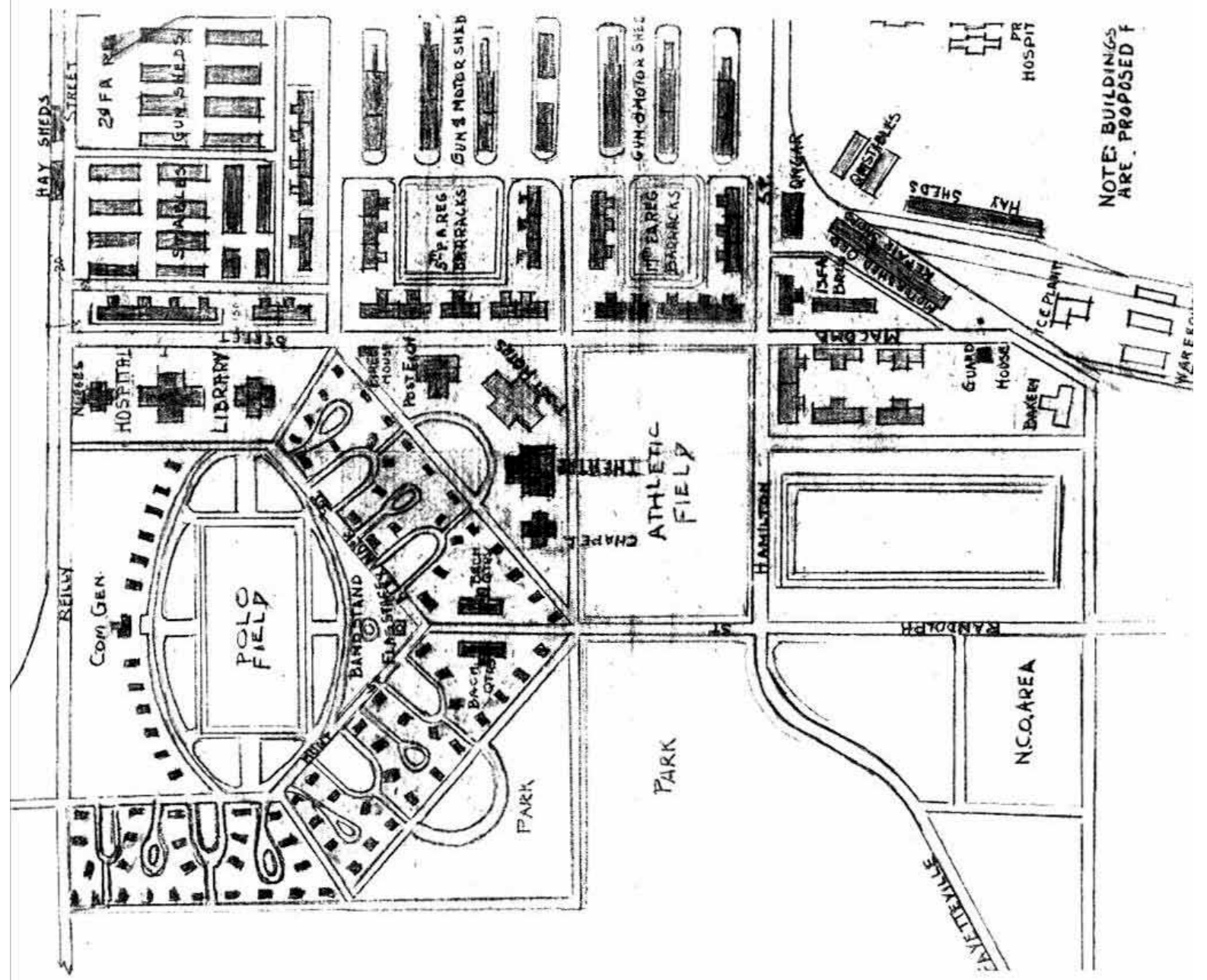

Figure 22. Plan of Fort Bragg by George B. Ford, 1926 (Fort Bragg Cultural Resources). 


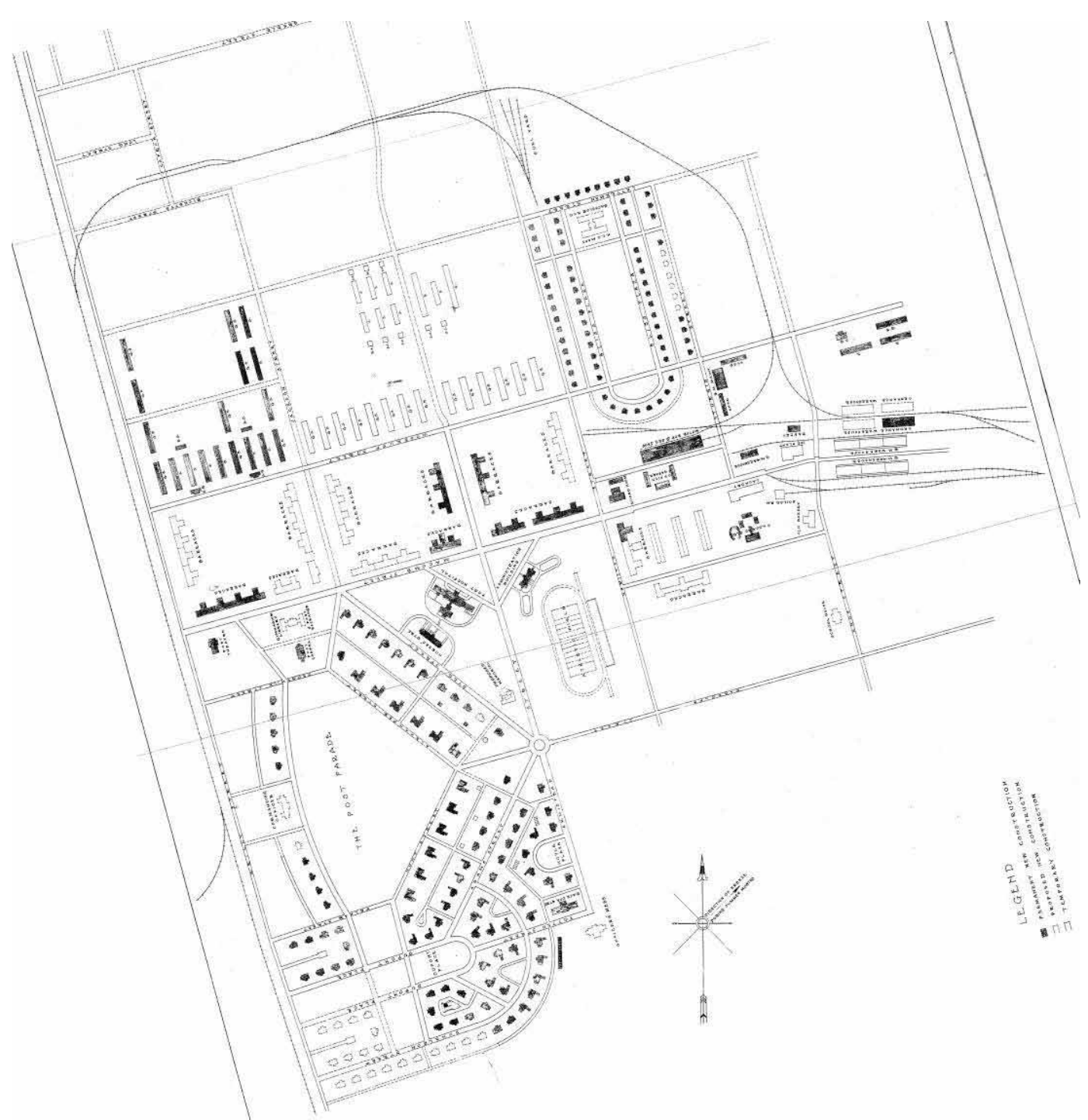

Figure 23. Plan of Fort Bragg showing layout, organization, and permanent construction, 1935 (Fort Bragg Cultural Resources).

The cantonment at Fort Bragg is 4026 acres and is located in the eastcentral region of the installation. The training and testing lands extend primarily to the west. The OPHD is a cohesive, intact, example of Army planning and permanent construction between WWI and WWII. Monumental architecture, tree-lined streets, and the plaza-like parade and polo fields are set in a Beaux Arts plan. The layout of the district is oriented along the east-west axis of Randolph Street, which extends from Bragg Boulevard - the historic connector to Fayetteville-through the traffic circle where the airborne trooper Iron Mike statue stands. The traffic circle provides intermediary focus while uniting Randolph, Armistead, Dyer, Adams, and Dragonway Streets and forms the apex of the stylized chevron design (Figure 24). 


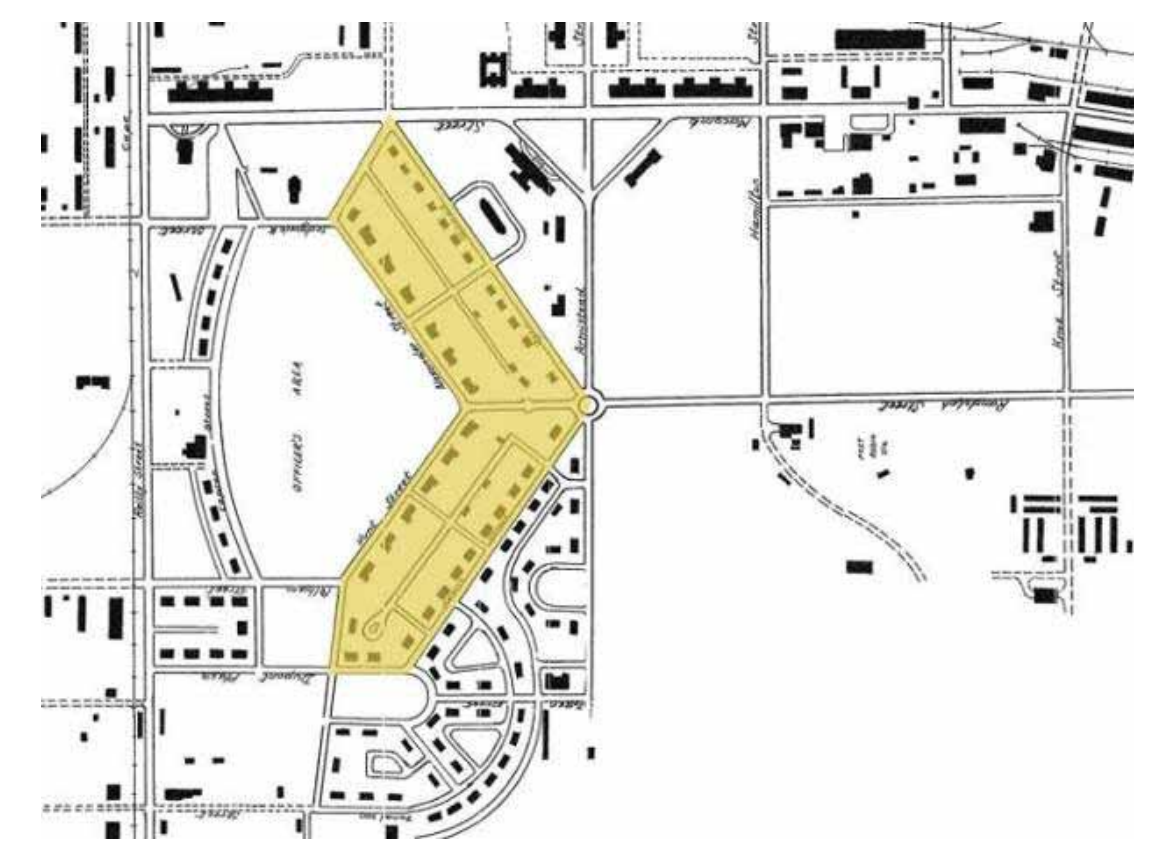

Figure 24. Normandy Heights chevron highlighted on a 1935 map (Fort Bragg Cultural Resources).

The area around the parade field, known as the "civic center," was designed in 1918 for the original WWI camp (Figures 25 and 26). The Main Post Chapel (1-1510) serves as a ceremonial anchor for the cross-axis of the parade field. The officer's housing area, called Normandy Heights, is arranged along geometric streets around the parade ground, with one and two-story Spanish Eclectic style houses set in mature landscaping of oak, maple, and magnolia. A picturesque Spanish Eclectic style Officers Club (1-4930) and Ryder golf course form the southern boundary of the officers' area. The non-commissioned officer's housing, known as Bastogne Gables, is a geometric grouping of approximately 100 Spanish Eclectic bungalows arranged around a central park in the northeastern section of the district one block north of Macomb Street. Only three WWI-period buildings remain: a gymnasium (2-1705) and two warehouses (8-3201 and 8-3502).

The administrative zone extends in a linear grid along Macomb Street. At its heart is the intersection of Armistead and Macomb Streets, where the Post Hospital (1-1326) and Post Headquarters (1-1333) diagonally face one another. Five large three-story barracks (2-1105, 2-1120, 2-1127, 2-1133, and 2-1138) stand along the north side of Macomb Street, two barracks (21728 and 2-1731) line Armistead Street, and one barrack unit (1-1242) is on the east side of Hamilton Street. 


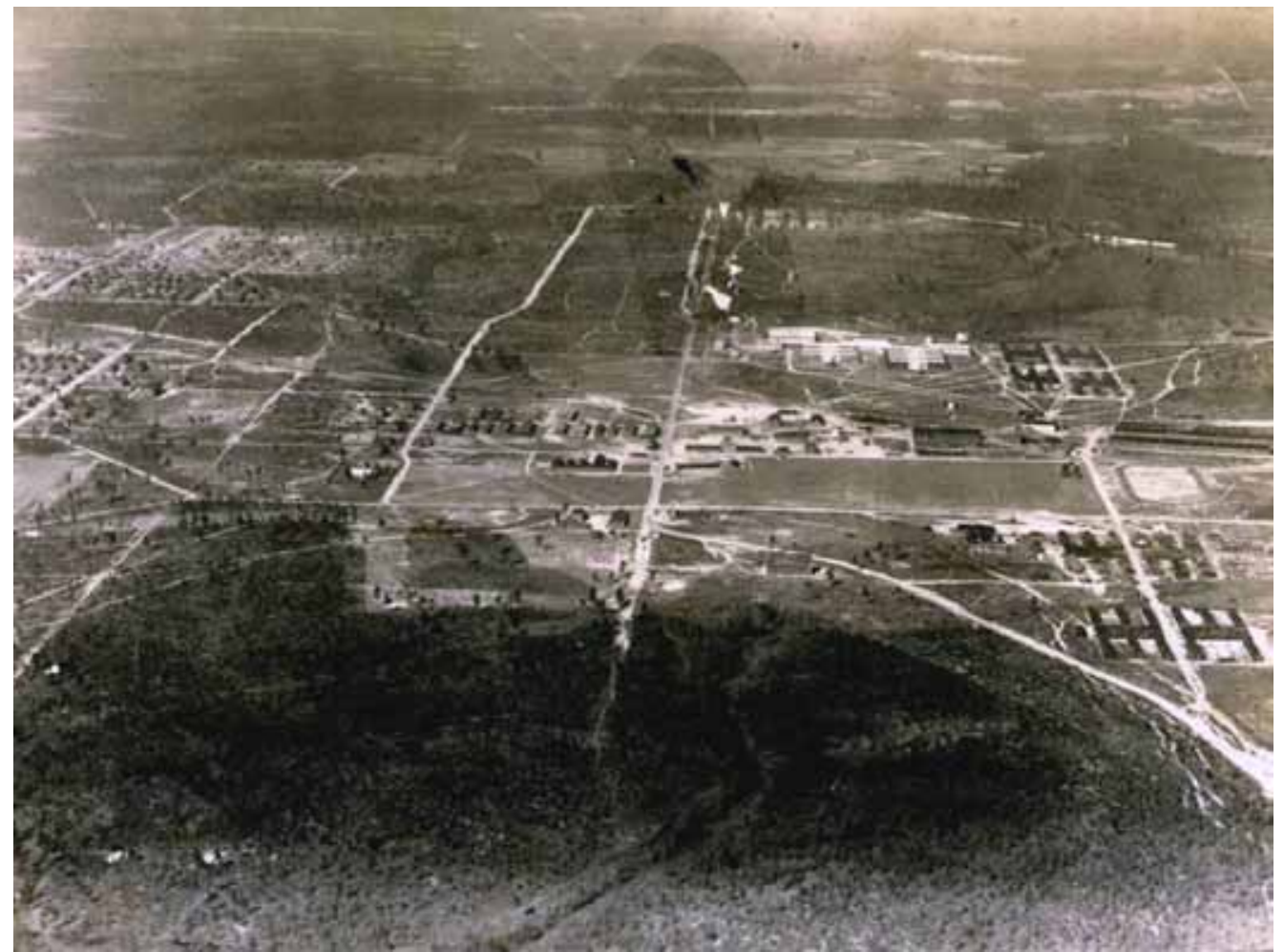

Figure 25. Aerial view looking north along Hamilton Street showing the civic center at the far left and the polo field in the middle ground, 1920s (Fort Bragg Cultural Resources).

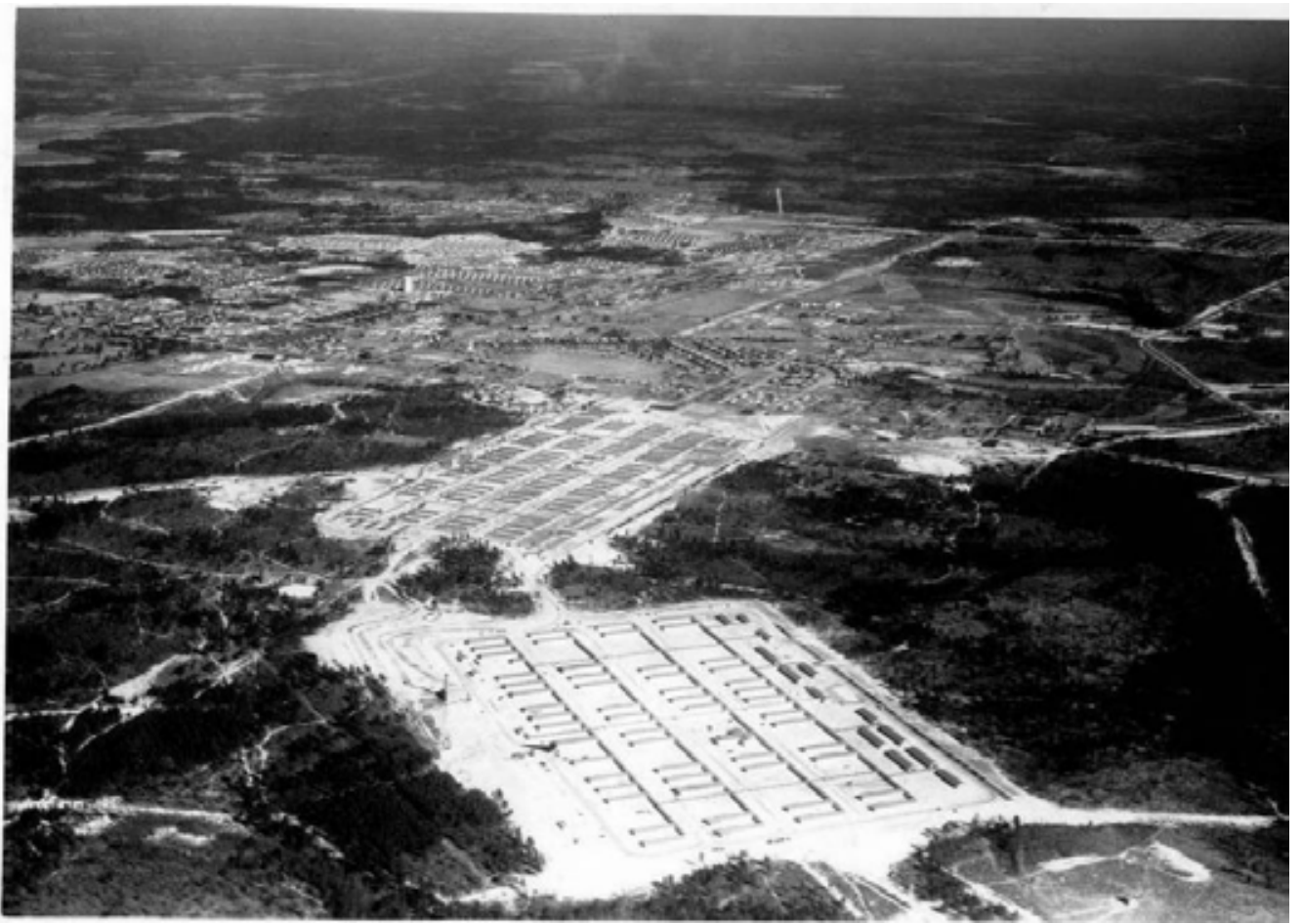

Figure 26. Aerial view looking northeast showing the civic center in the middle ground, 1940s (Fort Bragg Cultural Resources). 
Other significant buildings that make up the original permanent post are the Theater (1-1202), Guard House (2-1143), Finance and Quartermaster Corps Office (2-1148), Telephone Exchange (2-1114), Red Cross (1-1139), Commissary (2-1256), and Ordnance/ Motor Repair Shop (2-1252) along Macomb Street, with a Heavy Gun Shop (2-1549) and warehouses on adjacent streets.

\section{Land Use}

The military mission also directs how the military uses the land. As different missions are implemented, some land uses on an installation may change while some uses may remain the same (Loechl et al. 1996, p 70). Most landscape changes on a military installation are related to the military mission, some directly while others indirectly. In general, land use at Fort Bragg has remained consistent.

Land use areas directly related to the mission at Fort Bragg include the artillery testing ranges, airfield, and training areas. The areas indirectly related to the mission include the housing areas, administrative, recreation, commercial, and education areas. The main mission-related landscape of the OPHD is the mule barn area. The barns were arranged in long rows with corrals in between to accommodate the care of the animals. The area was planned and built in response to the WWI need to maintain mounted artillery units (Figure 27). The barns were later converted to the Motor Transport District (Figure 28) and although they remain, they have been converted to other uses, such as storage, maintenance, and retail services.

Housing, administration, education, recreation, and commercial areas are all indirectly related to the mission on an installation. Typically these land use areas stay consistent over the years. The major change in land use in the OPHD is the conversion of barracks and the old hospital to administrative offices. Even though the use and interiors of the buildings have changed, the exteriors of the buildings largely remain the same. This lends continuity to the historic district and helps to preserve the integrity of the district. 


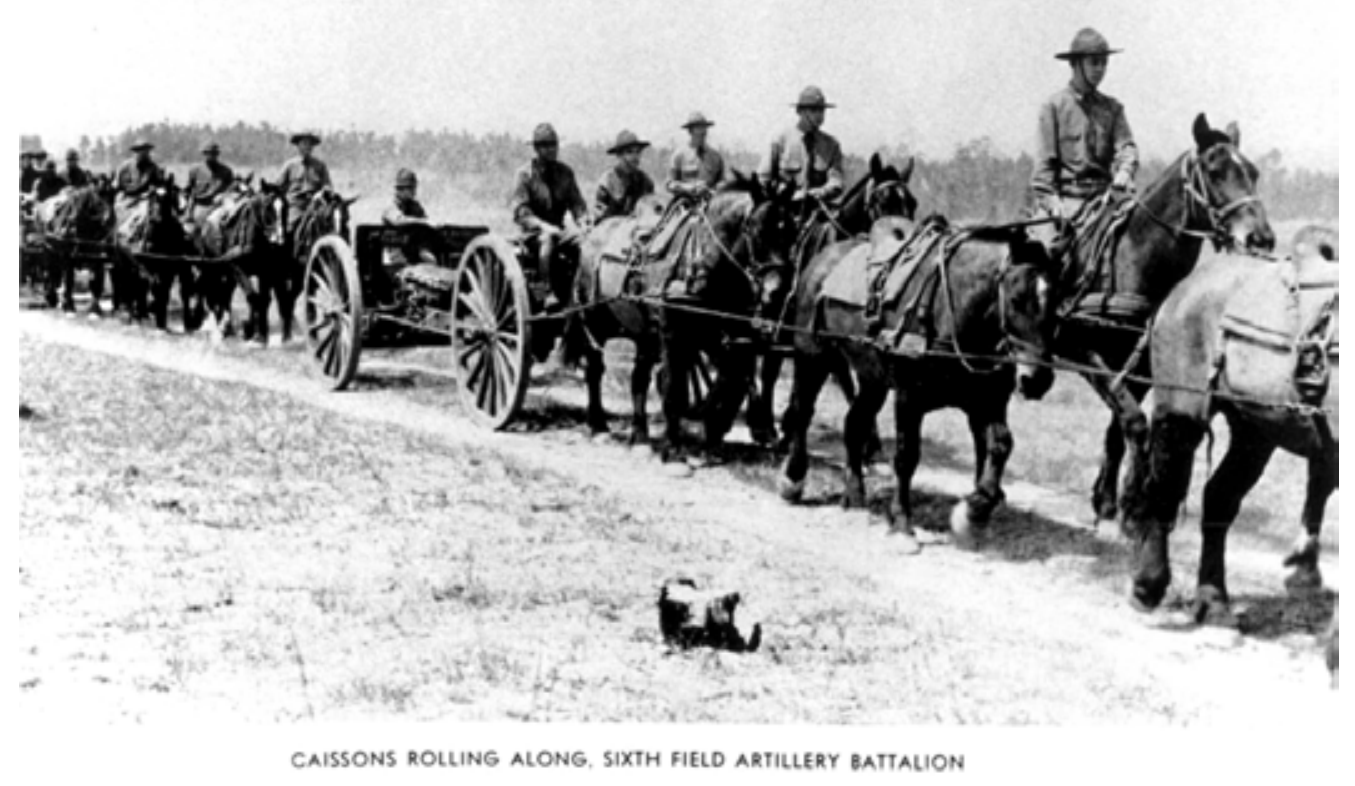

Figure 27. Sixth Field Artillery Battalion with horse drawn artillery, 1941 (Fort Bragg Cultural Resources).

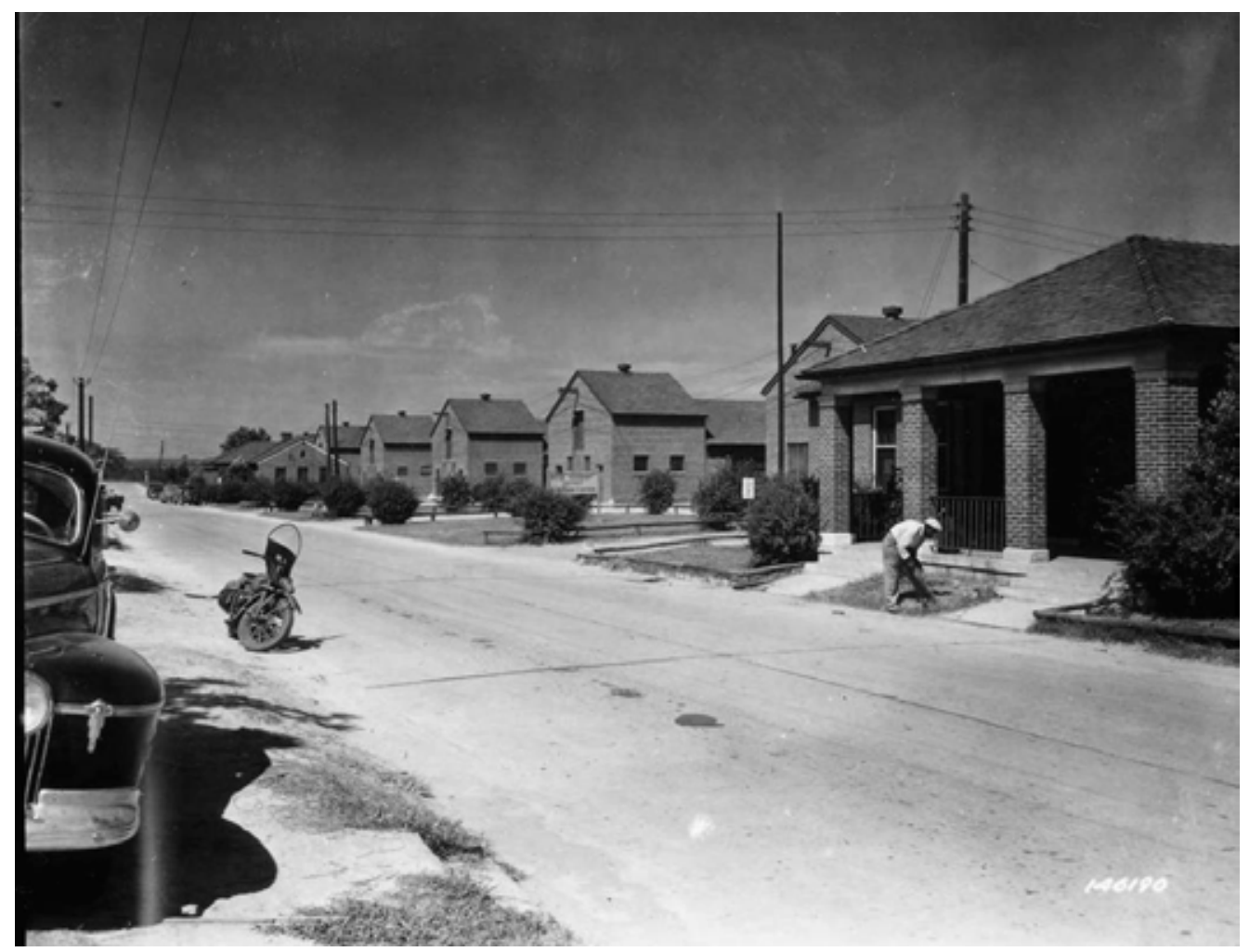

Figure 28. Motor Transport District, former mule bams, 27 August 1942 (NARA111-SC box 92 146190). 


\section{Expression of Military Cultural Traditions}

Military cultural traditions are reflected through military installations in both organization and aesthetics (Loechl et al. 1996, p 73). The military is a unique culture emphasizing ideas of hierarchy, discipline, utility, and patriotism. These values are physically manifested in the landscape giving military installations the appearance and sense of place that makes them easily recognizable (Loechl et al. 1996, p 73).

In the OPHD the organization and layout of the buildings and open spaces reflects the mission of the Army through their hierarchy and uniformity. The housing areas at Fort Bragg exhibit these values through the size, style, and location of the quarters. Hierarchy is expressed through the placement of the officers' quarters, the Normandy Heights neighborhood, along important areas in the cantonment such as the parade field and near the post headquarters (Figure 29). Both the unusual shaped parade ground and the location of the chapel reflect hierarchy and importance.

Fort Bragg's street infrastructure also expresses hierarchy in layout. Randolph Street, the main road into the cantonment, is wider than other streets and terminates at the flagpole and parade field. The main street is axially aligned to the most prominent support buildings on the post, which are the Headquarters, hospital, chapel, theater, and barracks. Additionally, the Commanding General's quarters is not along the parade ground, but instead near the traffic circle on Randolph Street, emphasizing the importance of the avenue as the entrance to the cantonment.

Most military installations have a high level of similarity; basic components and designs are repeated within the installation due to the use of standardized plans. WWI and WWII camps and the motor pool areas are good examples of this similarity. The layout of the historic district at Fort Bragg, based on city planning principals in the 1920s and 1930s, breaks up some of the similarity and uniformity of the WWI cantonment with the Ushaped housing areas and angled headquarters and hospital (Figure 30). 


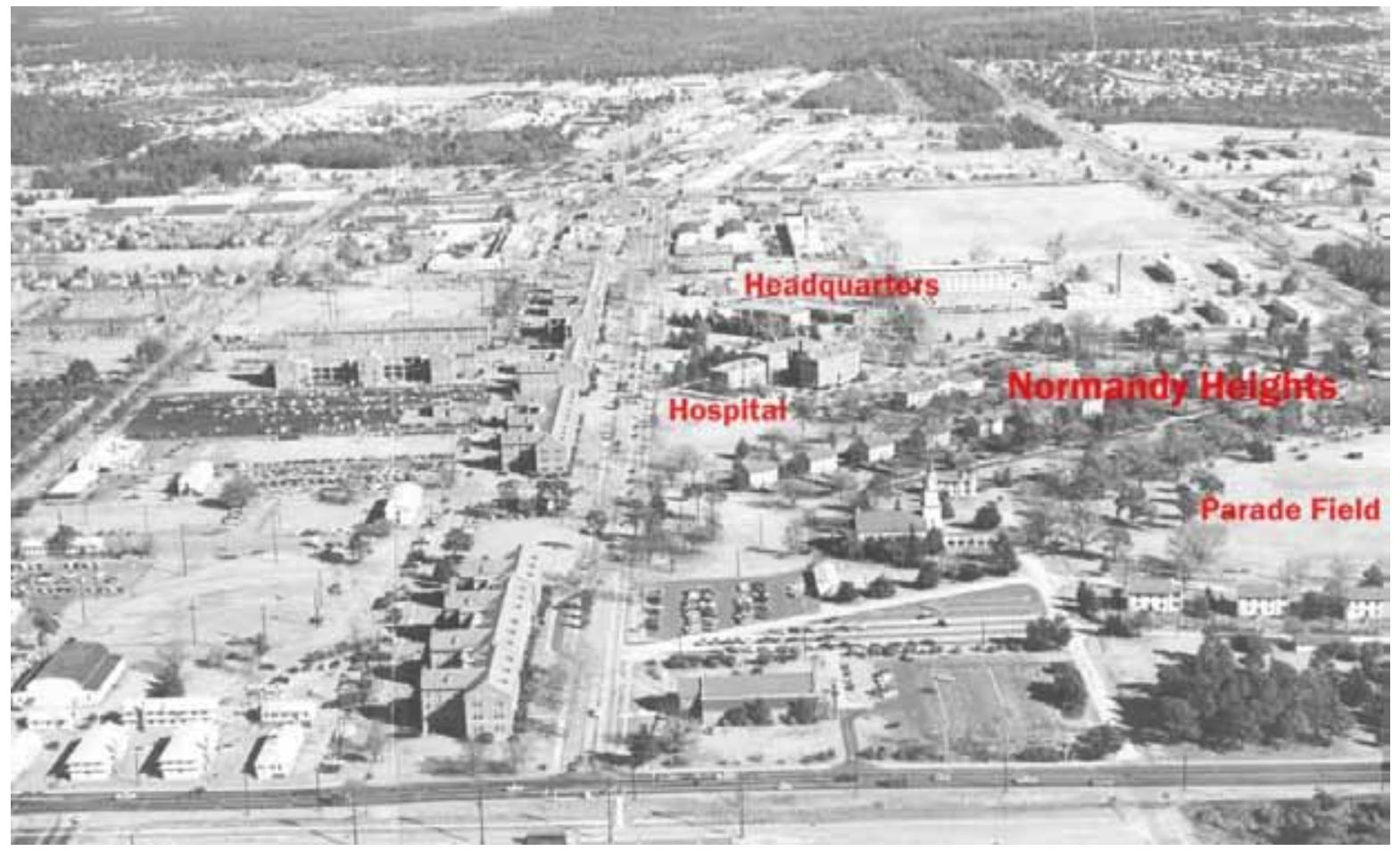

Figure 29. Relationship between Normandy Heights, Headquarters, and the hospital, 1968 aerial view looking east (Fort Bragg Cultural Resources).

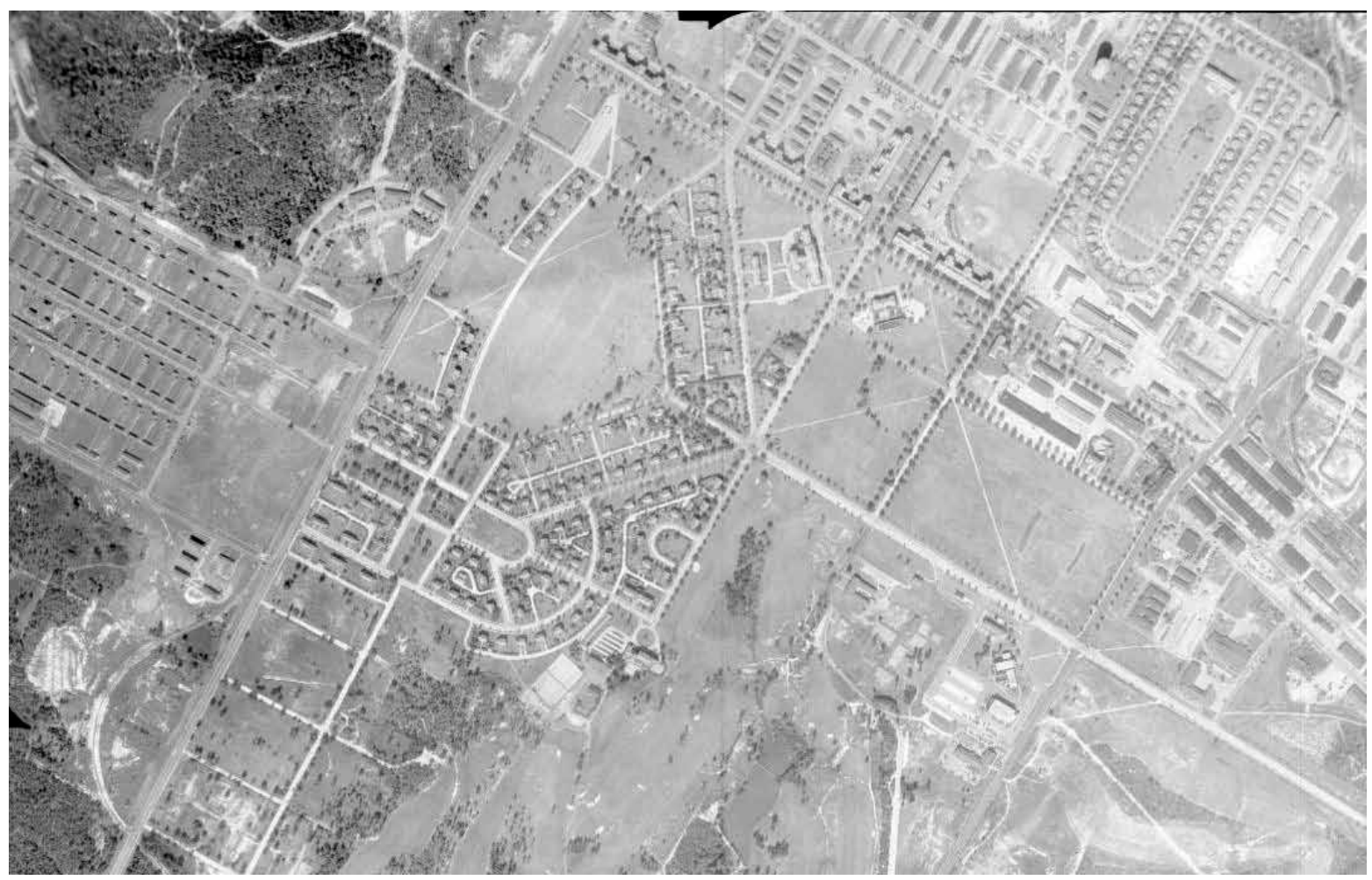

Figure 30. Aerial view of the OPHD, 1946 (Fort Bragg Cultural Resources). 
The main principle of installation development is to accommodate the mandated mission as quickly and efficiently as possible (Loechl 1996, $\mathrm{p} 70$ ). This often leads to a utilitarian landscape in which function is emphasized over aesthetics. At Fort Bragg, the mule barn area is an example of a utilitarian landscape. In this area, the emphasis on the buildings' function, use, and historical lack of plantings and embellishments make this a utilitarian landscape (Figure 31).

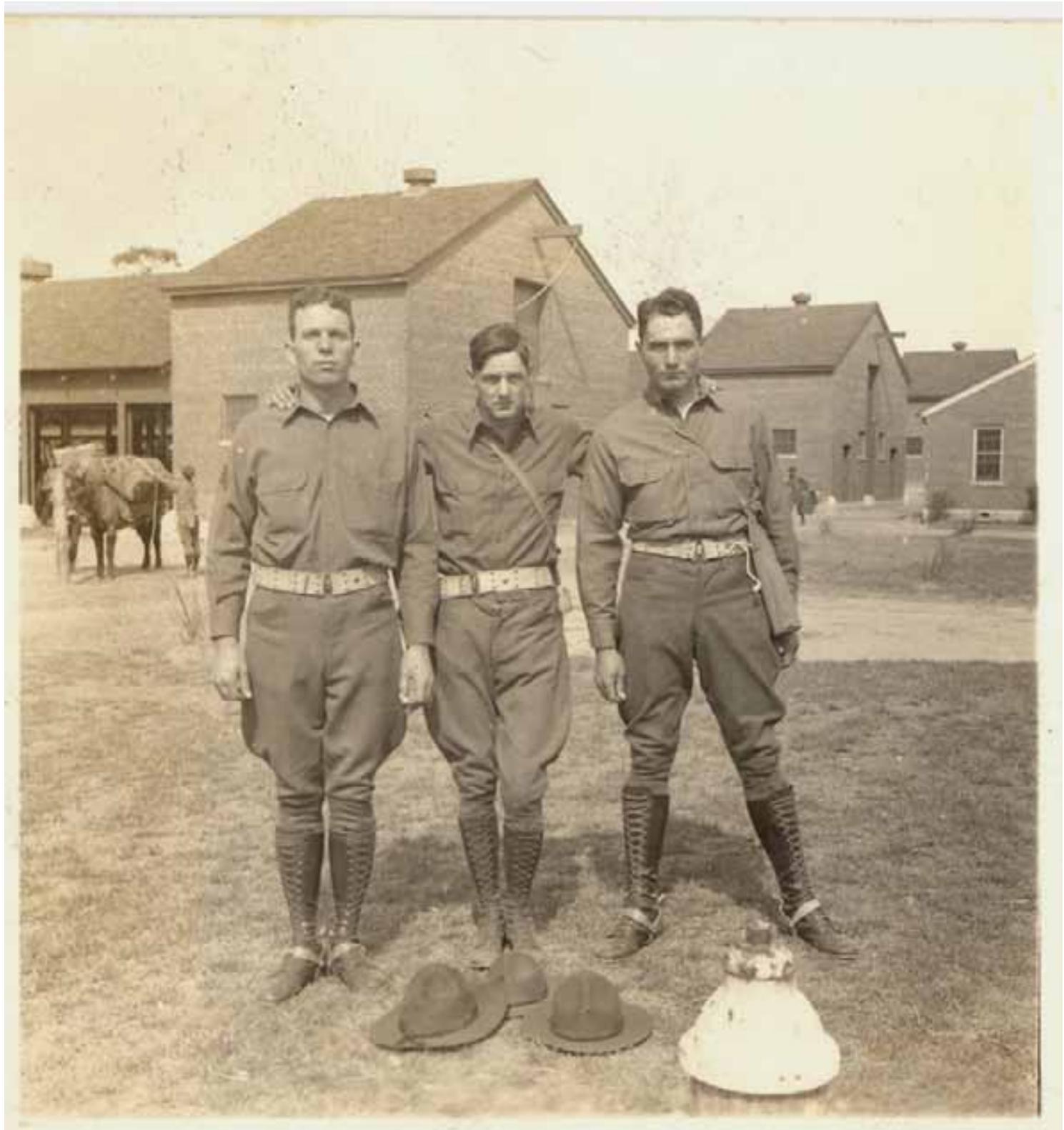

Figure 31. Soldiers in front of mule bams, undated (Fort Bragg Cultural Resources). 


\section{Transportation Networks}

Moving troops and equipment efficiently is an integral part of the military's mission, and transportation networks are an important characteristic of the military landscape. Facilitating efficient mobilization of troops and supplies these transportation systems have a distinct hierarchy (Loechl et al. 1996, p 77). Although the Sandhills area of North Carolina had some existing infrastructure, the construction of Fort Bragg brought increased transportation development to the area.

When the railroads bypassed Fayetteville in the 1830s, the major roads were upgraded with wood-planked surfaces. The longest plank road was the Fayetteville and Western Plank Road that extended 129 miles from Fayetteville to Salem, NC (Sharpe 1961; Wellman 1974). The twelve-foot wide plank roads were elevated and bordered by deep drainage ditches. Plank roads combined with well-developed riverine shipping ensured Fayetteville as the regional transportation and commercial hub (J ohnson 1977; Olmsted 1904 [1856]; Tullos 1989). However, with the exception of the region's major plank roads, the Sandhills road system was marginal under the best of circumstances. With the development of a regional railroad system in the 1850s, riverine transportation as the primary means of agricultural and forestry products shipping began its period of decline.

Fort Bragg was designed independently of the existing transportation infrastructure of the region. Randolph Street bisects the linear layout of the cantonment, terminating in a chevron-shaped parade field. Secondary streets extend from the axial streets creating blocks that are highly rectilinear and uniform. The primary and secondary roads were designed to carry the heaviest traffic and connect major land use areas, while the smaller tertiary roads, service lanes, and cul-de-sacs provide access to less traveled areas (Figures 32 and 33). Cantonment roadways to training and range areas generally follow the preexisting country road network.

Railway lines were built connecting the ordnance, quartermaster, magazines and ice house with the Cape Fear Railroad (Figures 34 and 35). Most of these lines are gone today as the mobilization of large numbers of troops is accomplished by air instead of rail. 


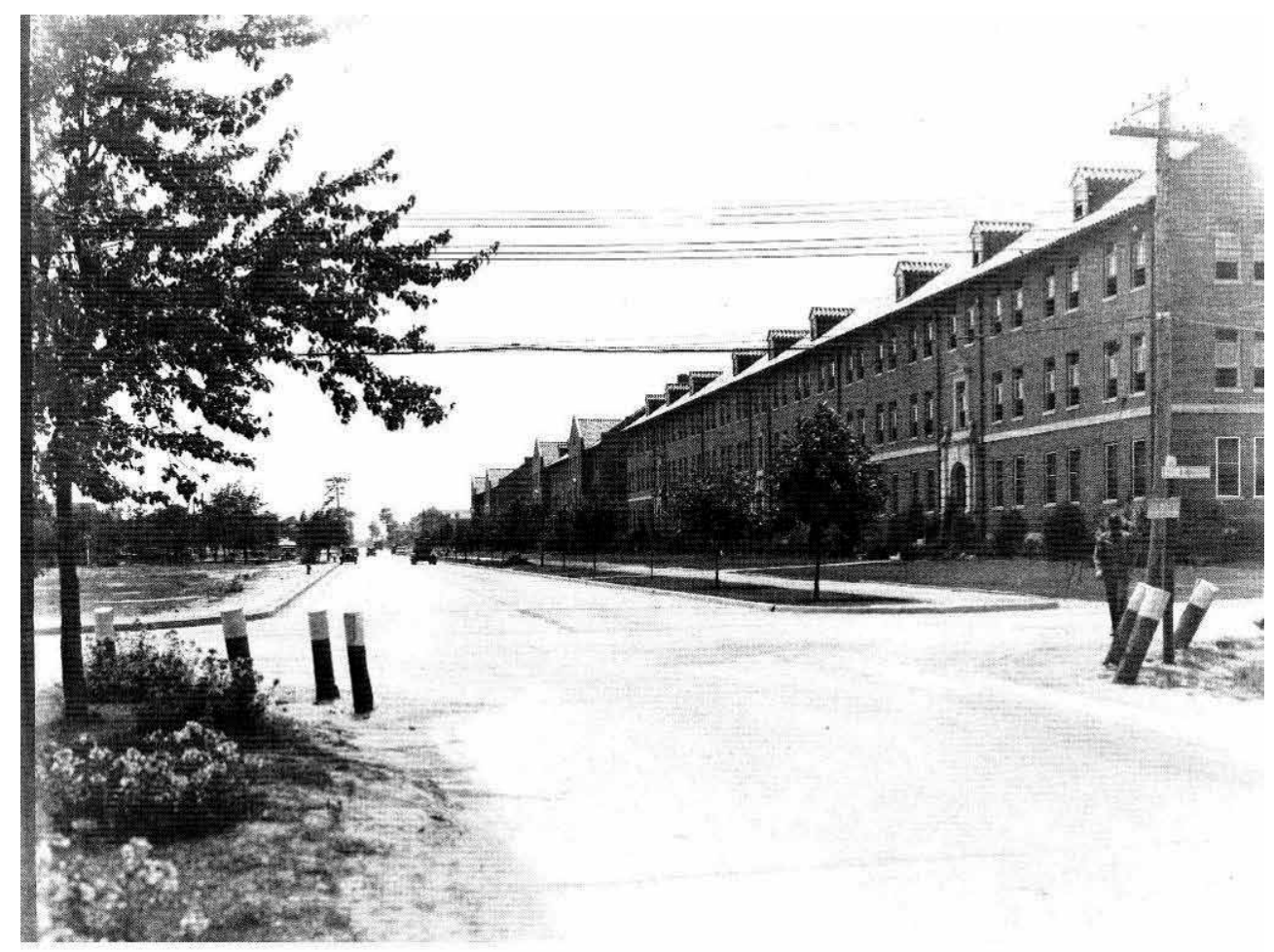

Figure 32. Street paving, combined curb and gutter, intersection of Randolph and Armistead, looking west, undated (NARARG-77-391 Boxes 49-52).

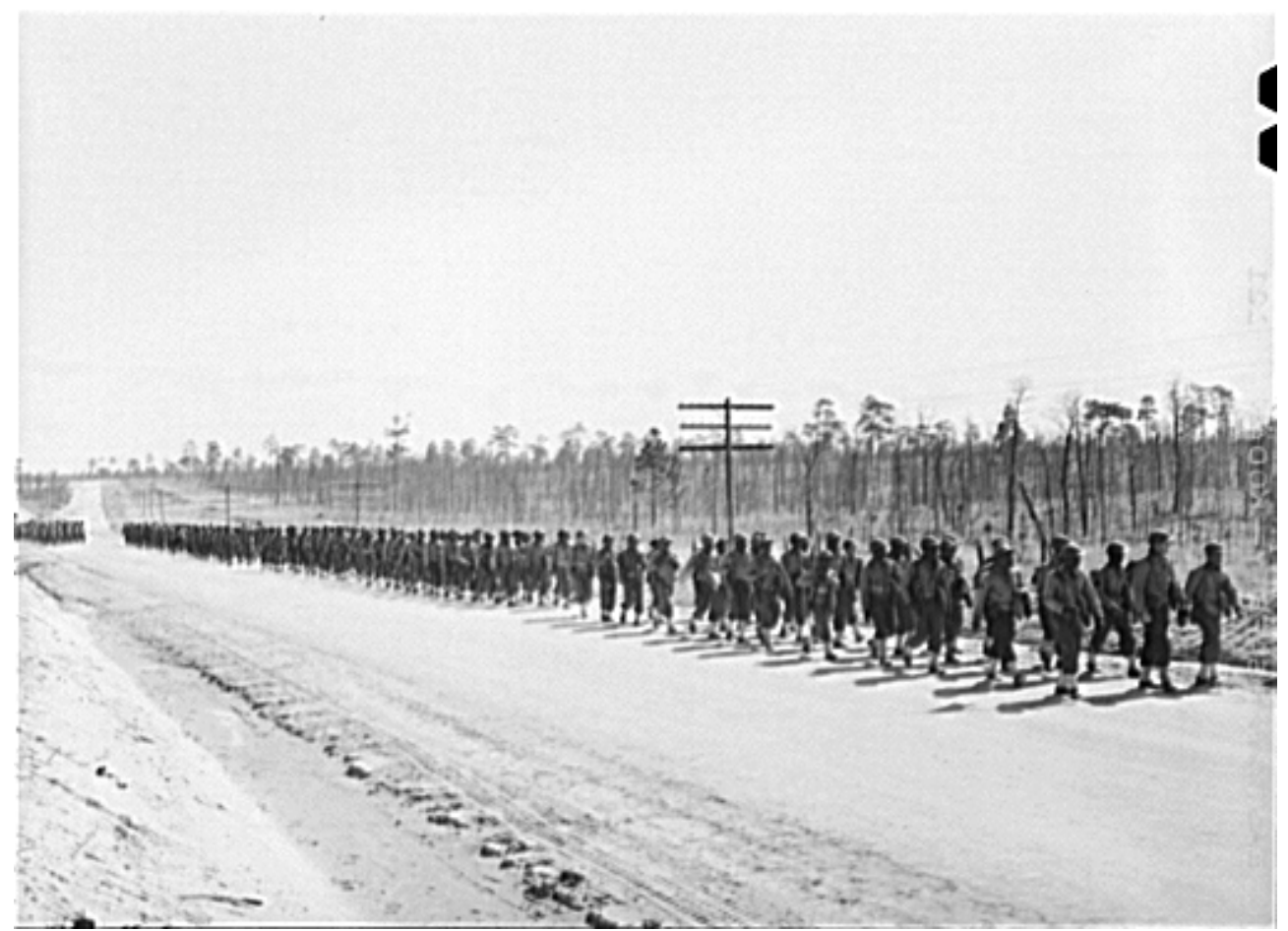

Figure 33. 41st Engineers on the march, showing the roads of Fort Bragg, 1942 (Library of Congress LC-USWB- 000502-D [P\&P]). 


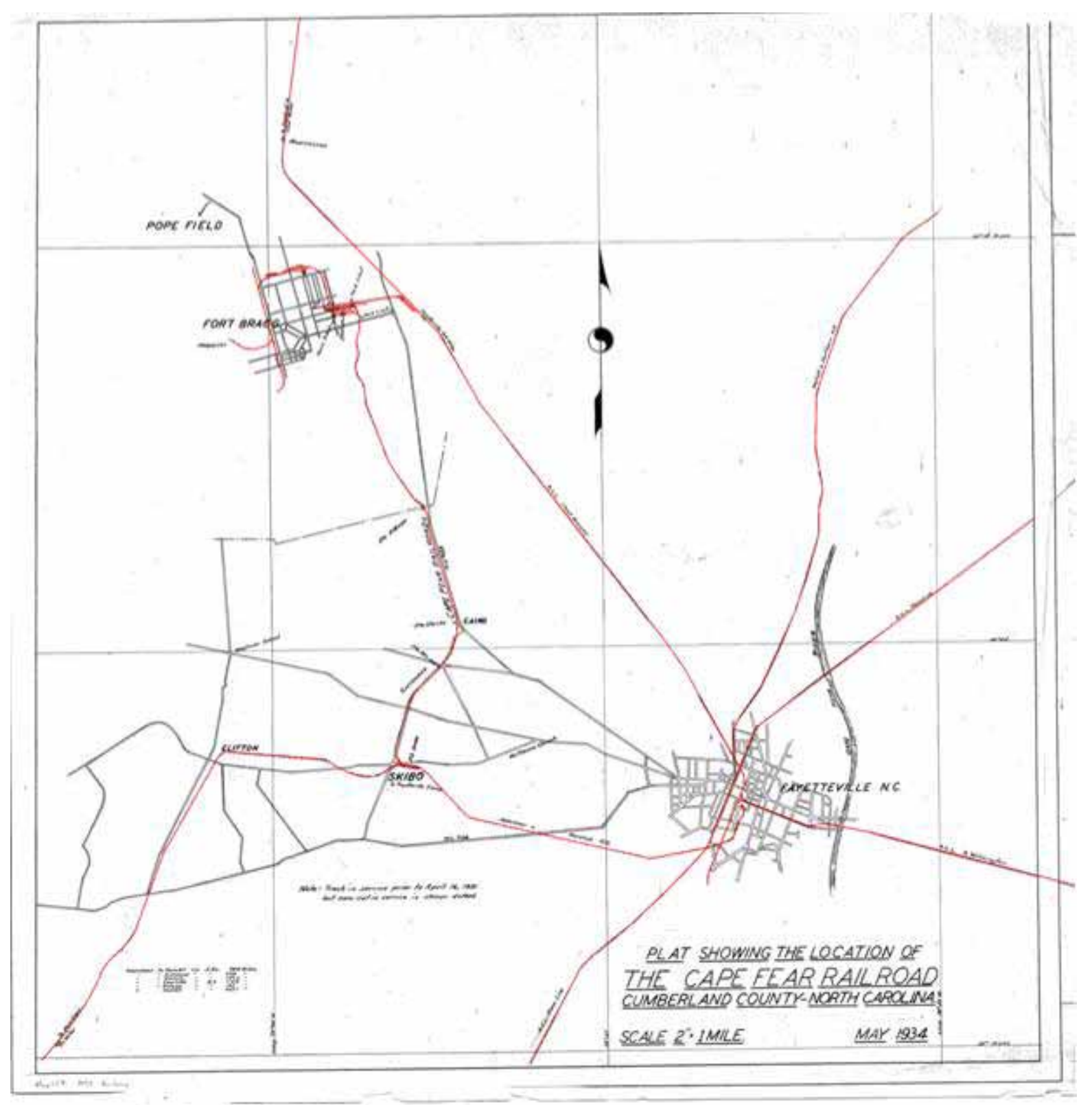

Figure 34. Plat showing the Cape Fear Railroad network, 1934 (Fort Bragg Cultural Resources). 


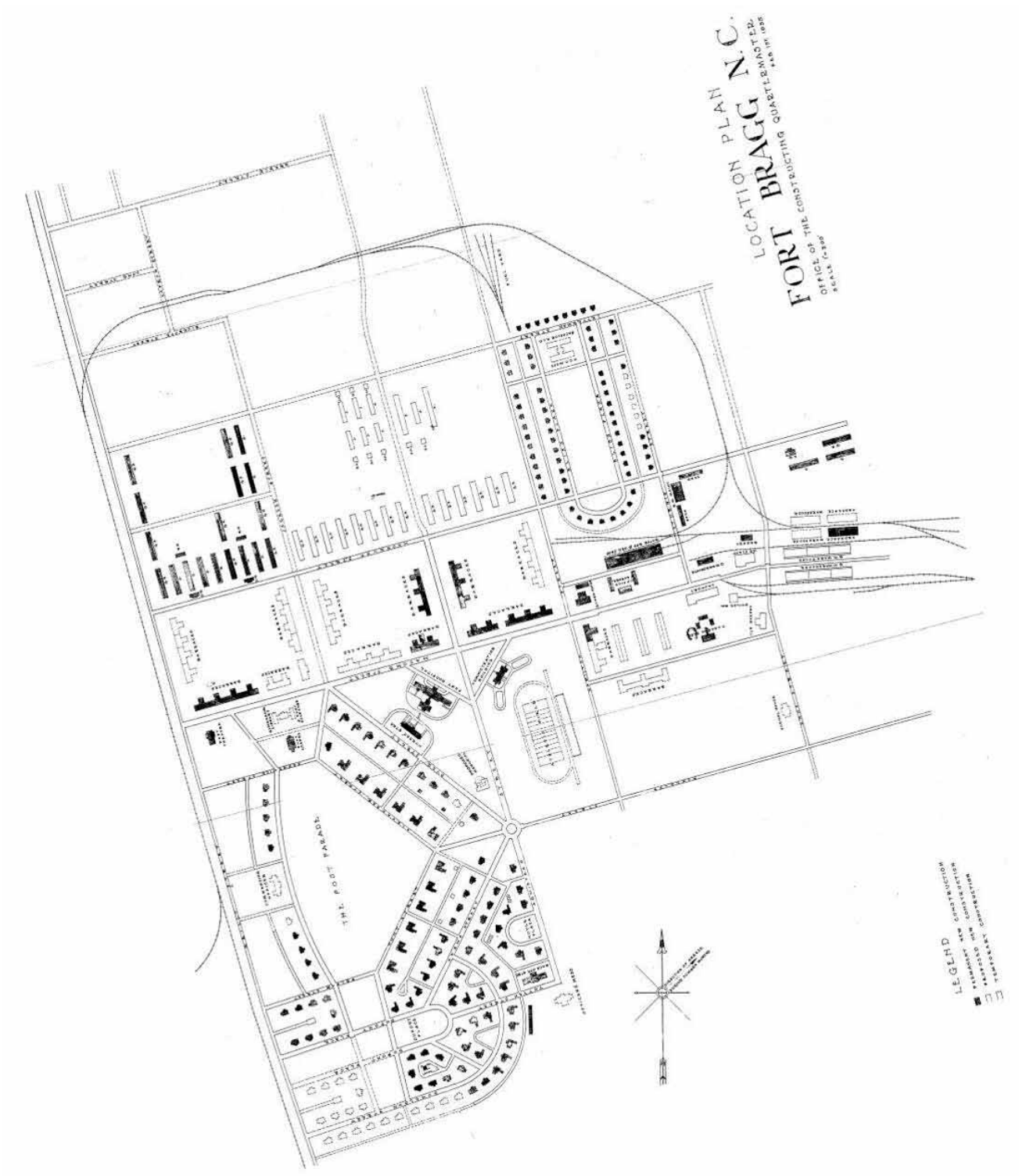

Figure 35. 1935 map of Fort Bragg showing rail lines in the OPHD, (Fort Bragg Cultural Resources).

\section{Views and Viewsheds}

A viewshed encompasses all visible elements that can be seen from a certain viewpoint. When elements of the landscape are composed into a scene or vista that can be seen in one direction, it is a view (Simonds 1961, pp 115-123). Terminal elements of a viewshed are emphasized through strategic openings in vegetation, down streets, or through cleared expanses. Fort Bragg has a variety of views and viewsheds in the OPHD. Fort Bragg has identified boundaries for the OPHD viewshed extents and a buffer area to guide future growth while preserving the historic characteristics of the district (Figure 36). 


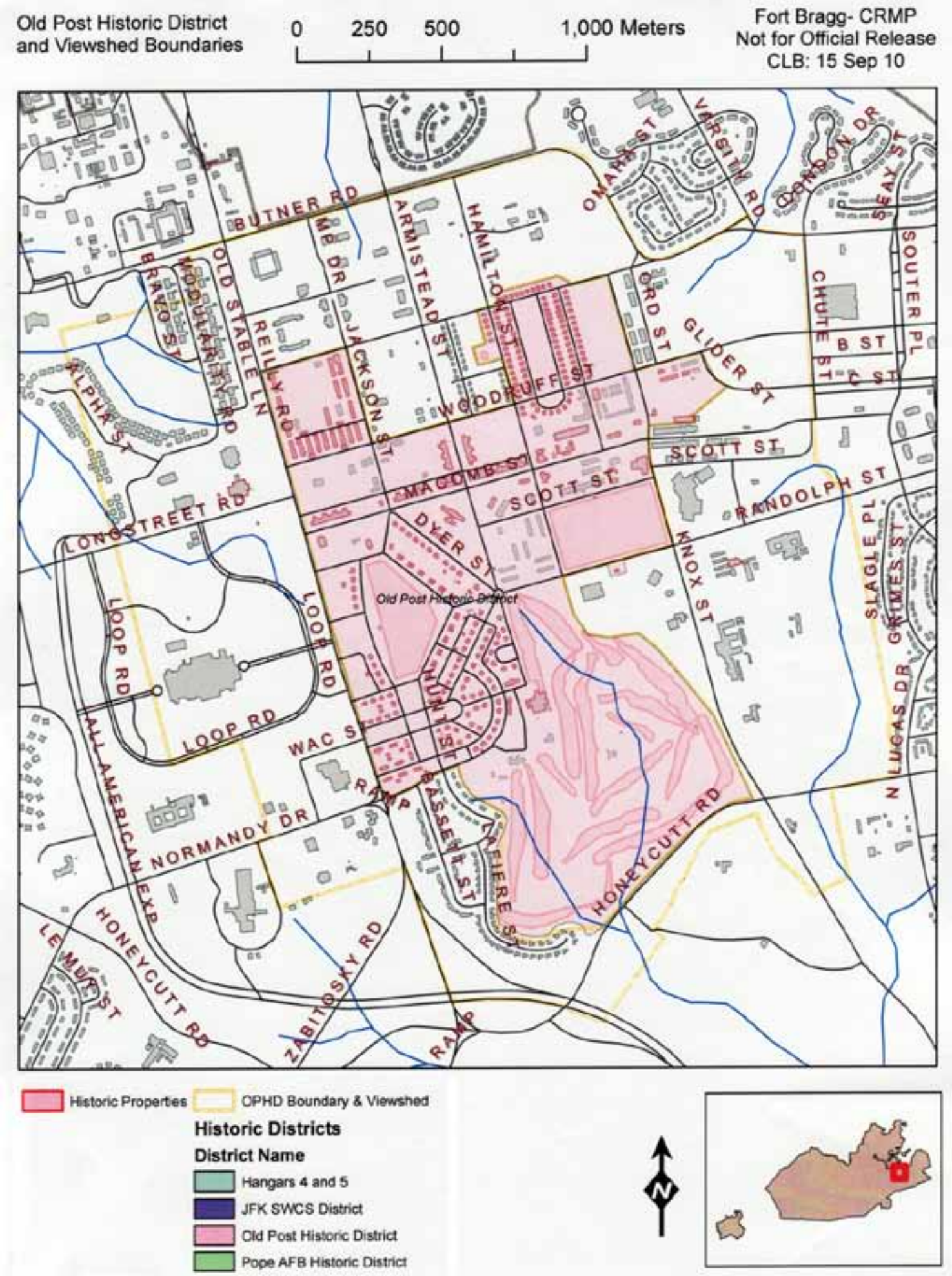

Figure 36. Map of OPHD viewshed boundary and buffer area (Fort Bragg Cultural Resources). 
Examples of views and viewsheds in the OPHD are the steeple of the Main Post Chapel, which is visible from many locations and is the northern terminus of the parade field (Figure 32). Also the view west along Randolph Street toward Iron Mike (Figure 36) and the flagpole area emphasizes the memorials and markers displayed there. Other important viewsheds in the historic district are the parade field, polo field, and the neighborhood parks of Dupont (Figure 38) and Humphrey Plazas.

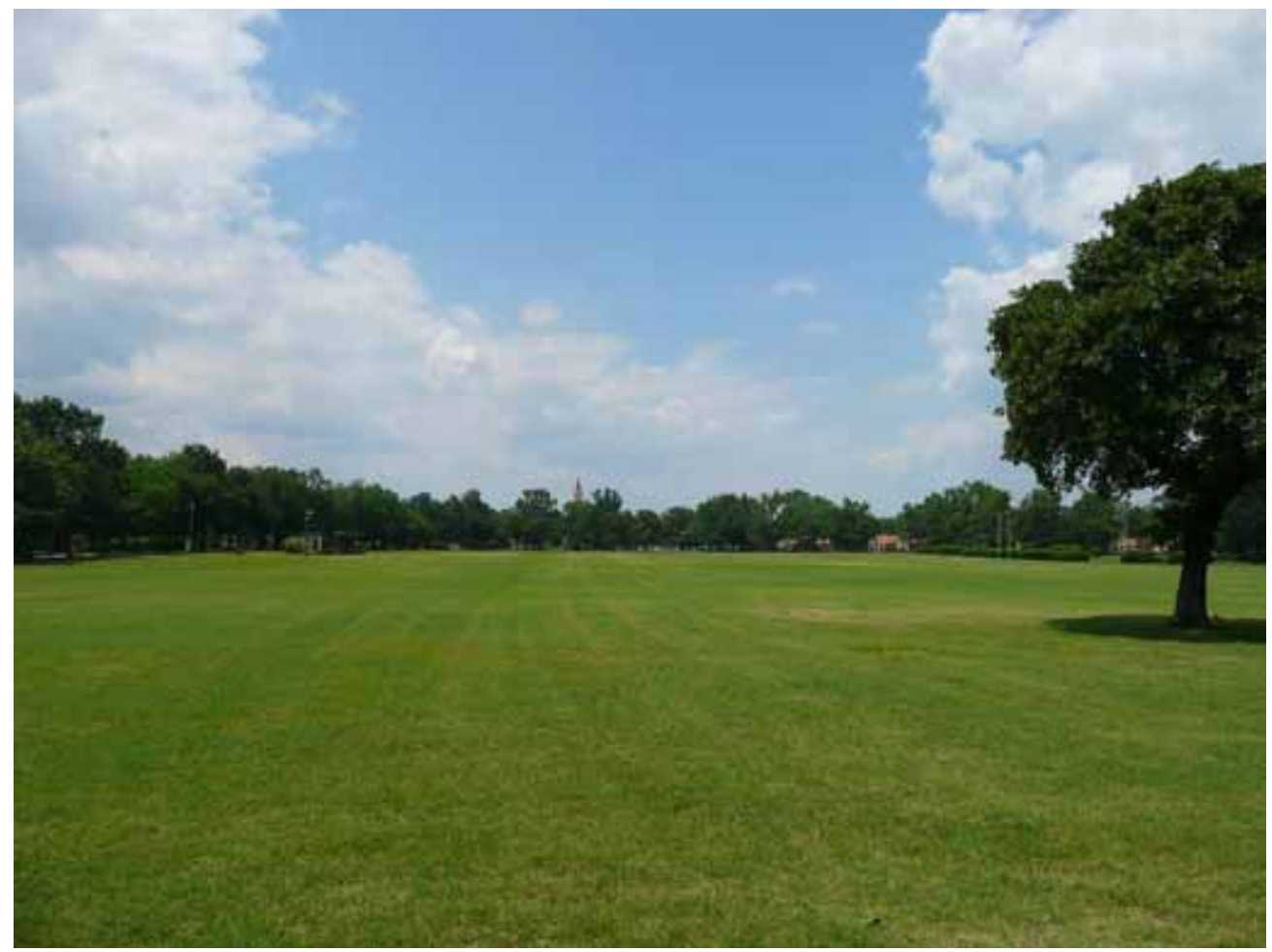

Figure 37. View north from the parade field to the Main Post Chapel, 2009 (ERDC-CERL). 


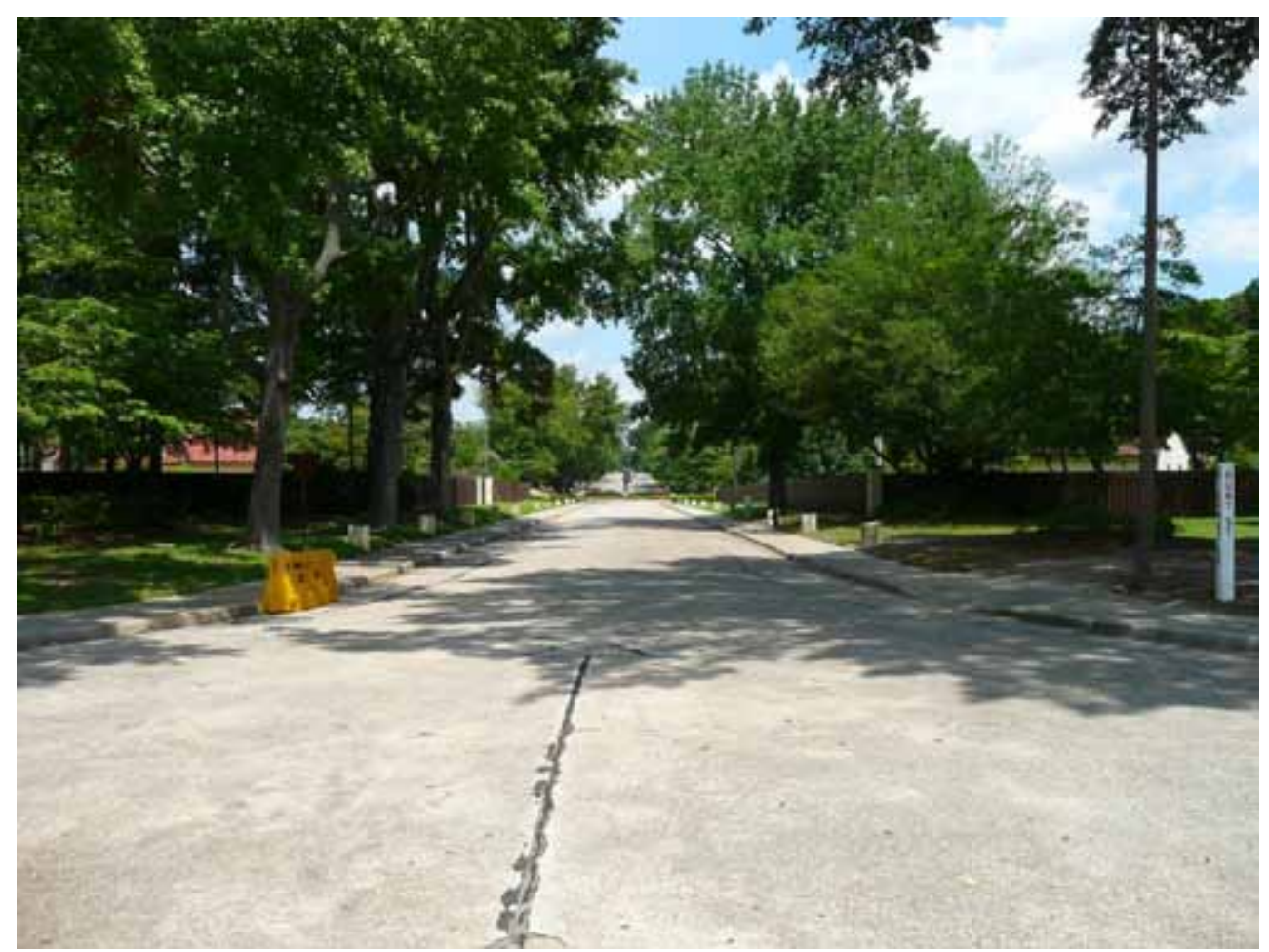

Figure 38. View east along Randolph Street framed by street trees looking toward Iron Mike sculpture, 2009 (ERDC-CERL).

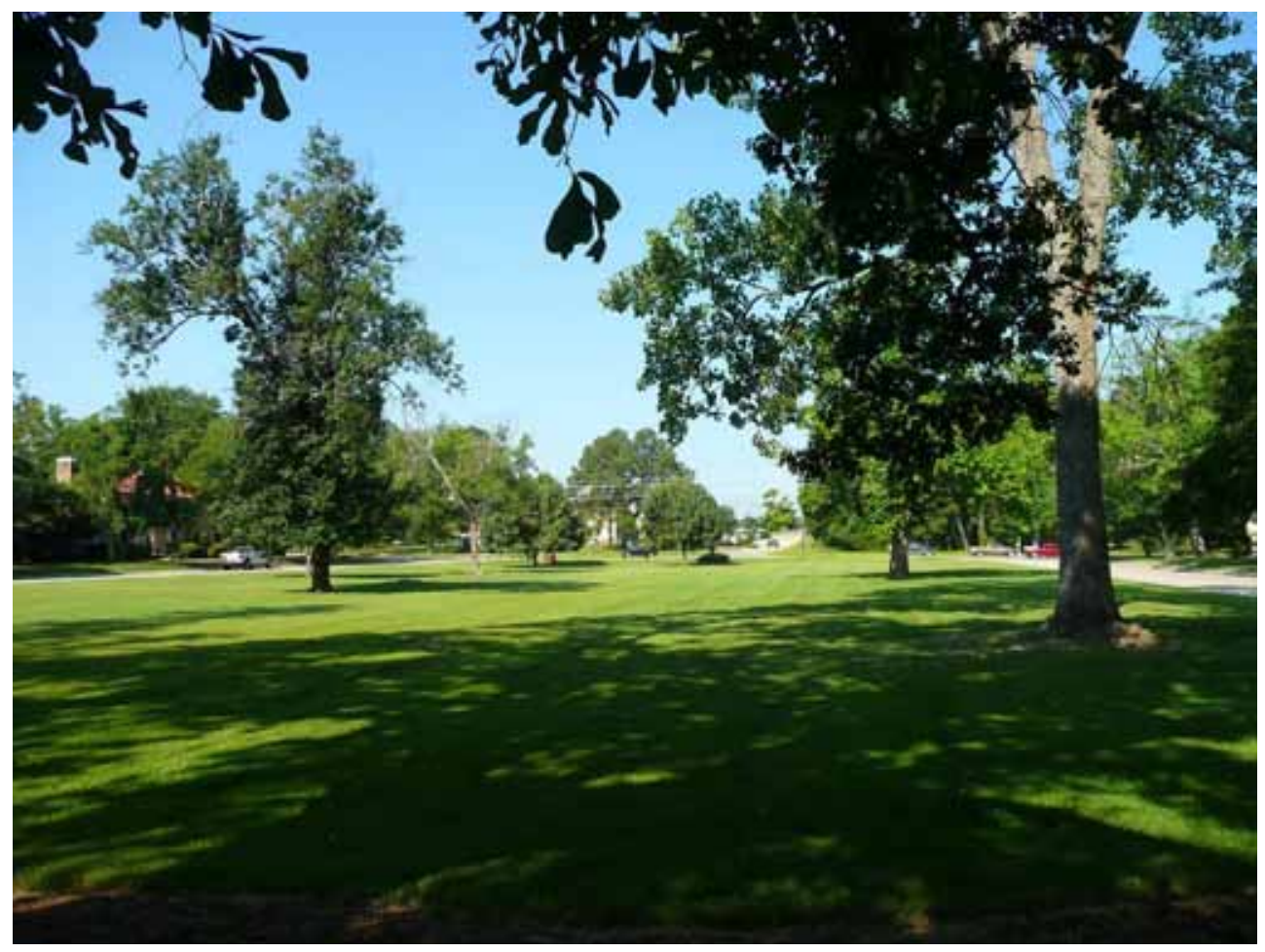

Figure 39. View east through Dupont Plaza, 2009 (ERDC-CERL). 


\section{Buildings and Structures}

The architecture of the OPHD is predominantly Spanish Eclectic and Georgian Revival styles. It is similar to that of other permanent posts in the southern United States developed during the 1920s and 1930s. For building types necessary to Army operations, using standardized building plans has been in practice since the late eighteenth century, becoming institutionalized in the 1890s. Some of the standardized plans came from buildings designed by architects, or local Constructing Quartermasters. In doing this, the Army could centralize building designs thus making building planning and construction more efficient. Usually the Washington office would send building plans to the local Constructing Quartermaster, who would then oversee the work of locally hired civilian contractors. This marked a change in operating procedures. In the nineteenth century the Constructing Quartermaster would act as the contracting officer with the troops providing the construction labor as described in the Federal Emergency Administration of Public Works Bulletin No. 15. Under the new practices the contract was offered in a bid that itemized the contract of work, materials, and costs. The selected contract was then awarded through the U.S. Government Combined Form No. O.K. 50. Through these bidding and contracting processes the War Department's Specifications for Construction were standardized; these detailed the materials and construction methods of every building to be built on an Army base.

The Army's standardizations evolved in the mid-1920s when the Quartermaster Corps introduced regionally appropriate architectural styles as opposed to what they had used before, simplified versions of nationally popular architecture styles. This responded to the idea of tailoring building designs to local climate conditions and architectural traditions. The Army selected two primary styles, which they called the "Colonial" of the Atlantic seaboard and the "Spanish Mission" of the American Southwest, standardizing them for use throughout the country (Ray 1994, p 9). The Colonial style, featuring buildings with brick exteriors and slate roofs, were built from New England south to Virginia, and is now known as Georgian Revival. Along the Mexican border, at posts in Texas and California, the Spanish Mission style was used ("Housing the Army" 1931, pp 11-13). One of the first trials of this building program was in 1924 at Fort Benning, GA where the construction of Dutch Colonial Revival style Officers' housing was criticized as being unsuitable for the hot Georgia summers (Grandine 1993, p I-207). 
Buildings and structures, often those similar in style and function, were grouped to act as a cohesive unit. Clusters were usually designed to create a symbiotic relationship with the exteriors and interiors (Loechl 1996, $\mathrm{p}$ 87). The footprints of buildings, their massing, their spacing, and the circulation between structures are integral to understanding the military landscape (Figure 40).

The master plan of Fort Bragg grouped buildings together with similar purposes; barracks were arrayed linearly, administration buildings were clustered, and the housing areas were built as U-shaped, cohesive neighborhoods around central open areas. Individual groupings share common design elements such as uniform setbacks, architectural styling, and building scale (Figures 41 and 42).

Industrial buildings did not receive these stylized treatments and continued to follow the functional, industrial designs that were developed in the early 1900s. However, by the late 1930s military designs were deviating from the standardized plans into styles popular at the time; an example of this on Fort Bragg is the Heavy Gun Shop (2-1549). The Heavy Gun shop was built in 1934 and is located in the Quartermaster Support Area; it is a steel and brick building with International-style detailing.

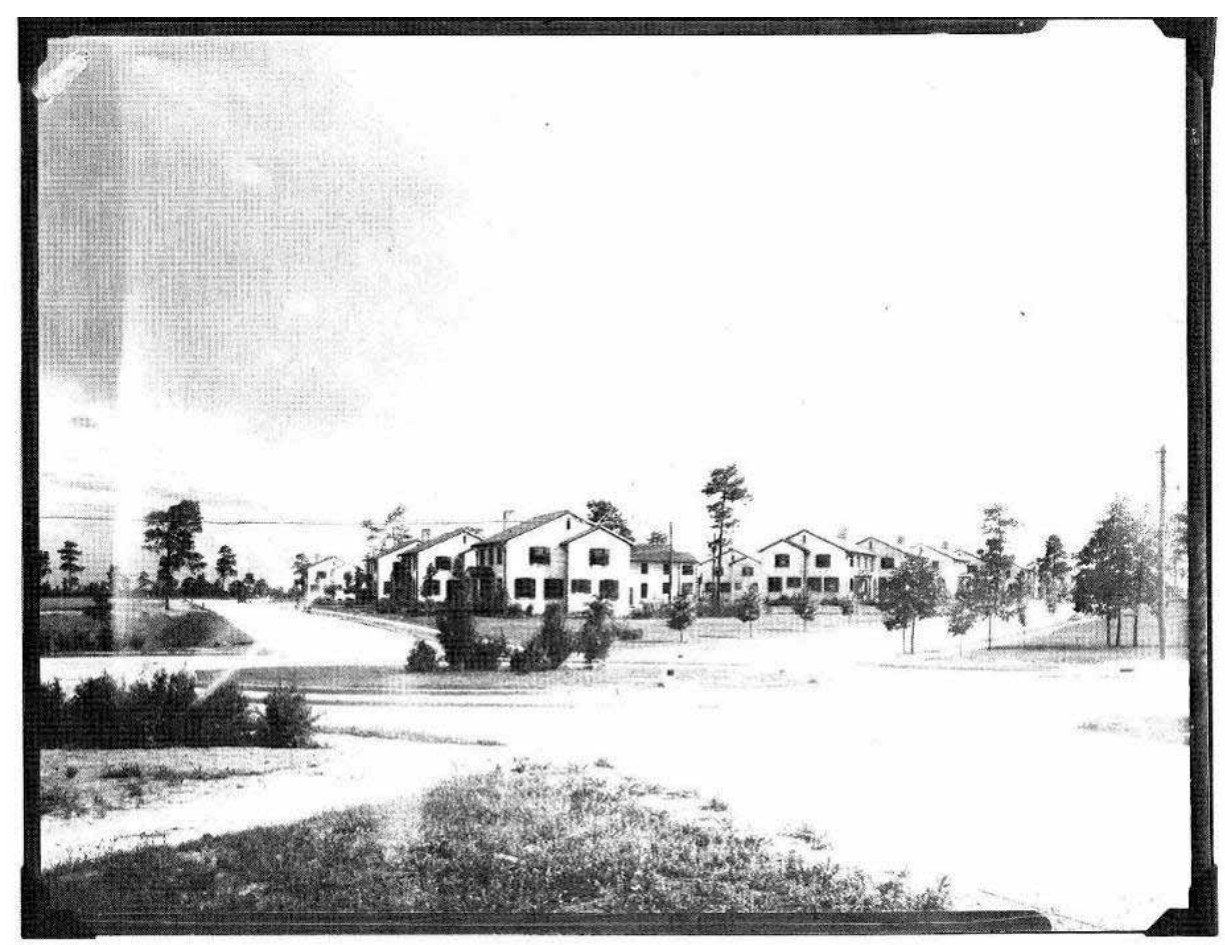

Figure 40. Field and Company Officers' Quarters in the standardized Spanish Eclectic style, 1941 (Fort Bragg Cultural Resources). 


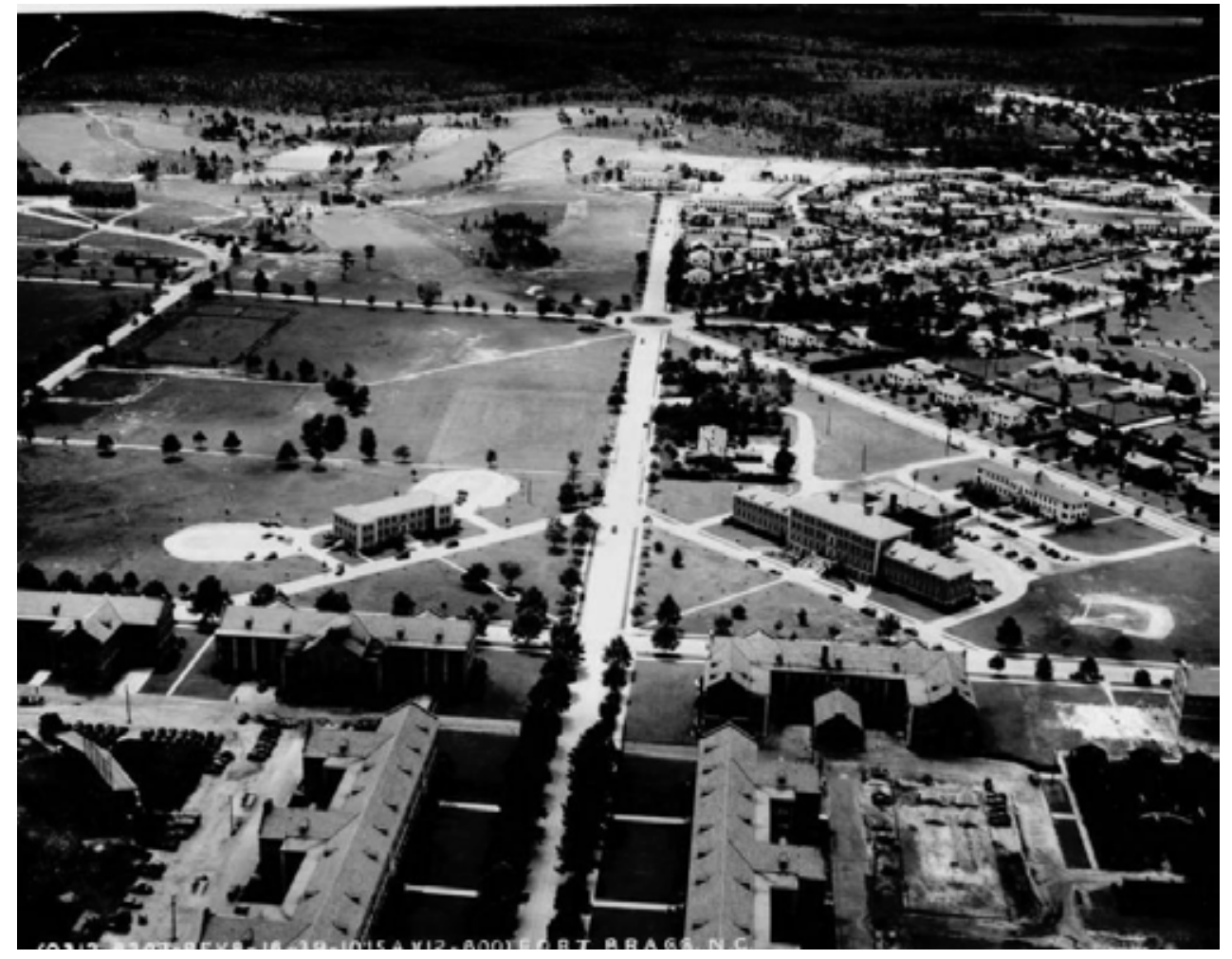

Figure 41. Aerial image of Fort Bragg looking south showing the barracks, administration/ hospital, and housing areas, 1939 (NARARG-342-FH-bx1060-

B17347[1939OPHD.])

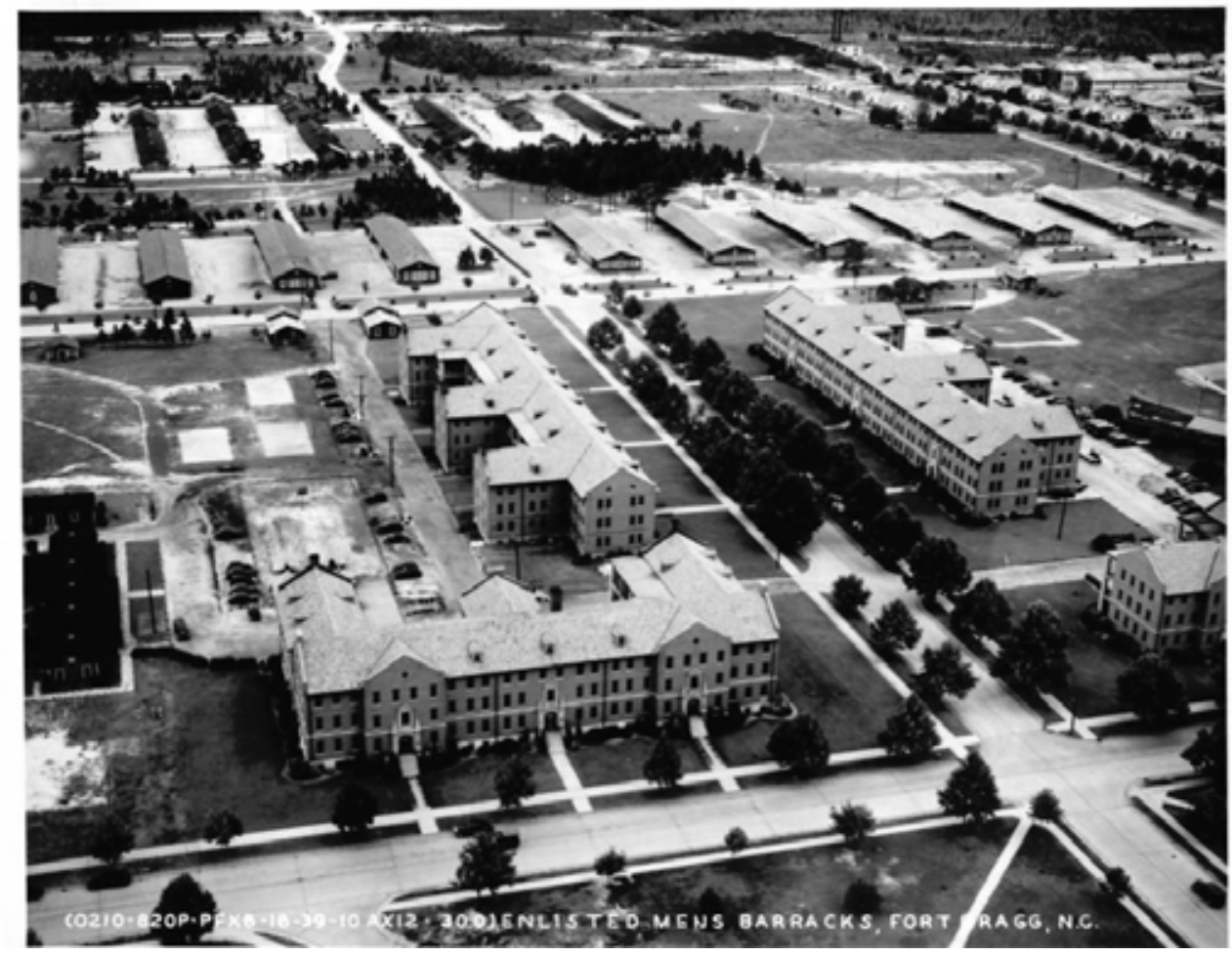

Figure 42. Aerial image of Enlisted Men's Barracks, 1939 (National Archives RG342-FH-bx1060-B17348). 


\section{Vegetation}

On military installations, patterns of vegetation may designate boundaries, specific land uses, and natural areas (Loechl et al. 1996, p 83). Vegetation also delineates hierarchy of spaces; for example, the more prominent support buildings such as headquarters, chapels, hospitals, and officers' clubs have more elaborate landscaping than more utilitarian buildings such as motor pools, quartermaster, and warehouse areas. The vegetation patterns at Fort Bragg illustrate these ideas (Figures 43-49).

The native vegetation of the Fort Bragg area is primarily longleaf pine forest. Before military occupation the pine forests were exploited for naval stores, but the forests were not significantly diminished. By 1931, the Construction Division of the Quartermaster Corps had established a "Landscape Unit" to assist installations with the goal of improving their grounds. Standardized landscape plans were developed for standardized buildings such as chapels, hospitals, and theaters (Appendix B). The intention was to plant trees and shrubs that "harmonized" with the standardized plans and add aesthetics to the more prominent buildings on the installation.

In his 1939 article, "Landscaping the Army Post," E. Mack Hallauer identified several principals - unity, practicality, and simplicity -as the aims of good landscape design (Hallauer 1939, p 28). He encouraged the use of plant material acceptable to the existing soil, climate, and local conditions as well as the use of trees and shrubs to screen, frame views, separate areas, and shade. At Fort Bragg, this was especially emphasized with the 1920s and 1930s landscaping providing an oasis in the midst of the barren scrub oak and pine landscape of the Sandhills region.

The OPHD has mature street trees along prominent roads and most of the residential streets. The street trees-mostly oaks, maples, sycamores, and magnolias - add character to the historic district. The historic neighborhoods of Normandy Heights and Bastogne Gables have street trees as well as many other kinds of plantings. Before privatization of military housing, the residential landscaping was left to the residents and consequently, the plantings vary from house to house. 


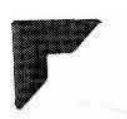

\section{7}

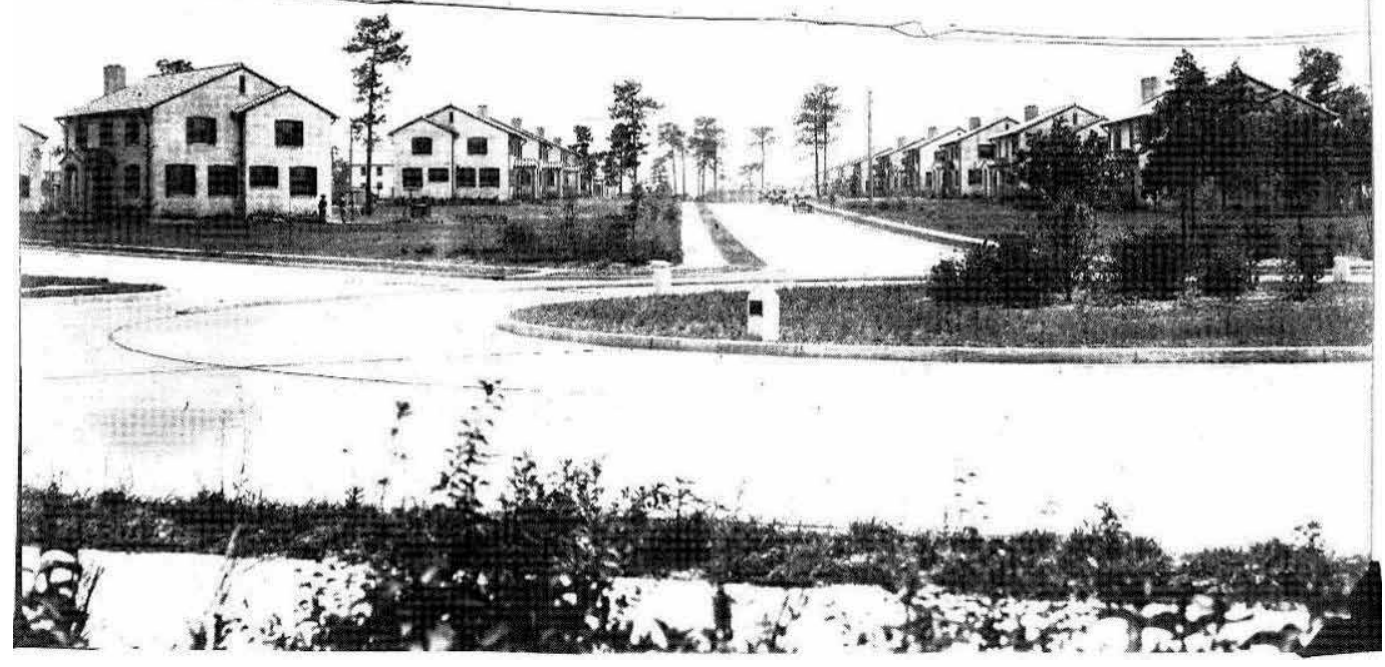

Figure 43. Field and company officers' quarters, looking south on Amistead Street, 1941 (Fort Bragg Cultural Resources).

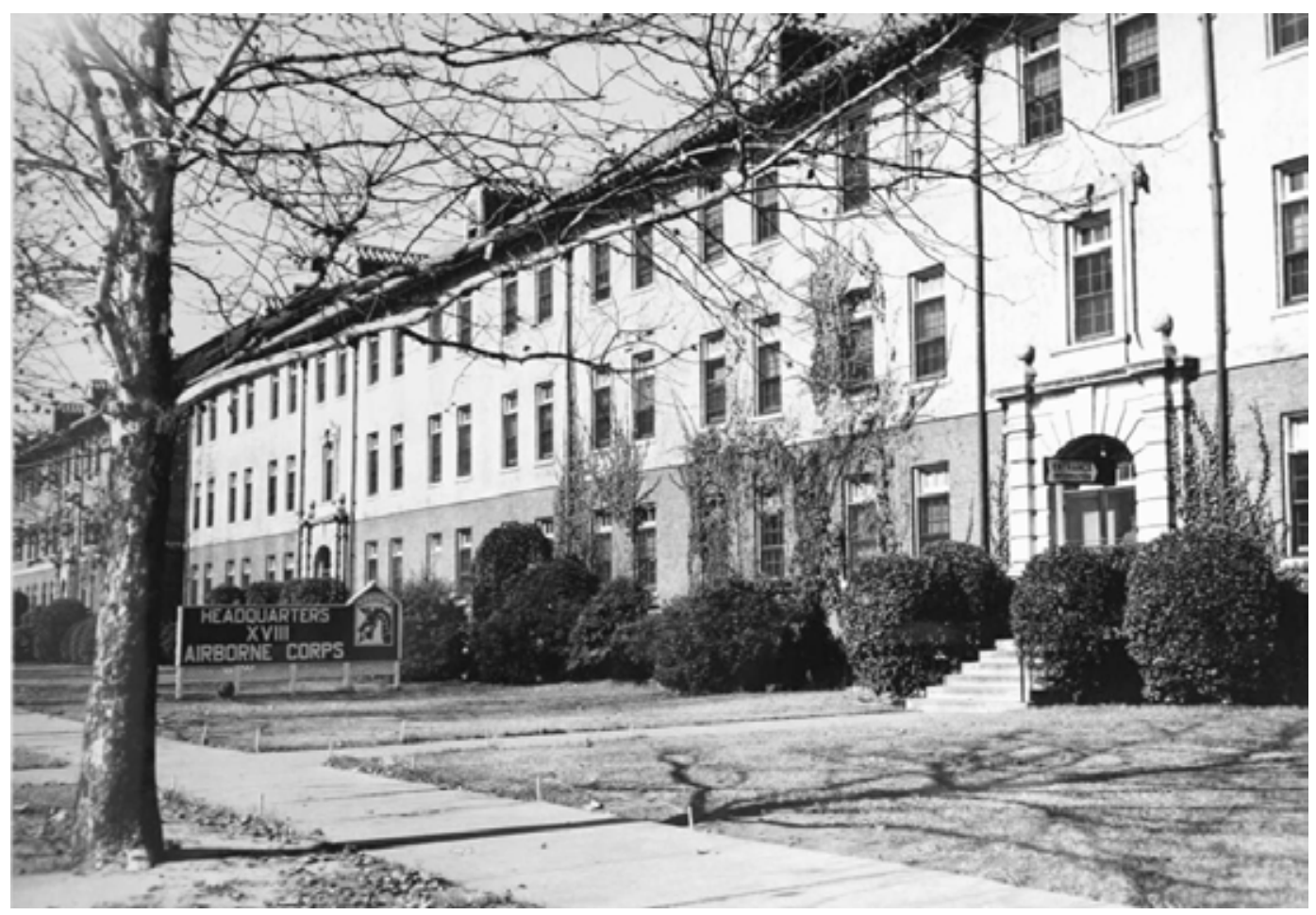

Figure 44. One of the Macomb Barracks converted to the headquarters building showing foundation plantings, undated (NARASC111, Box 220, 386330). 


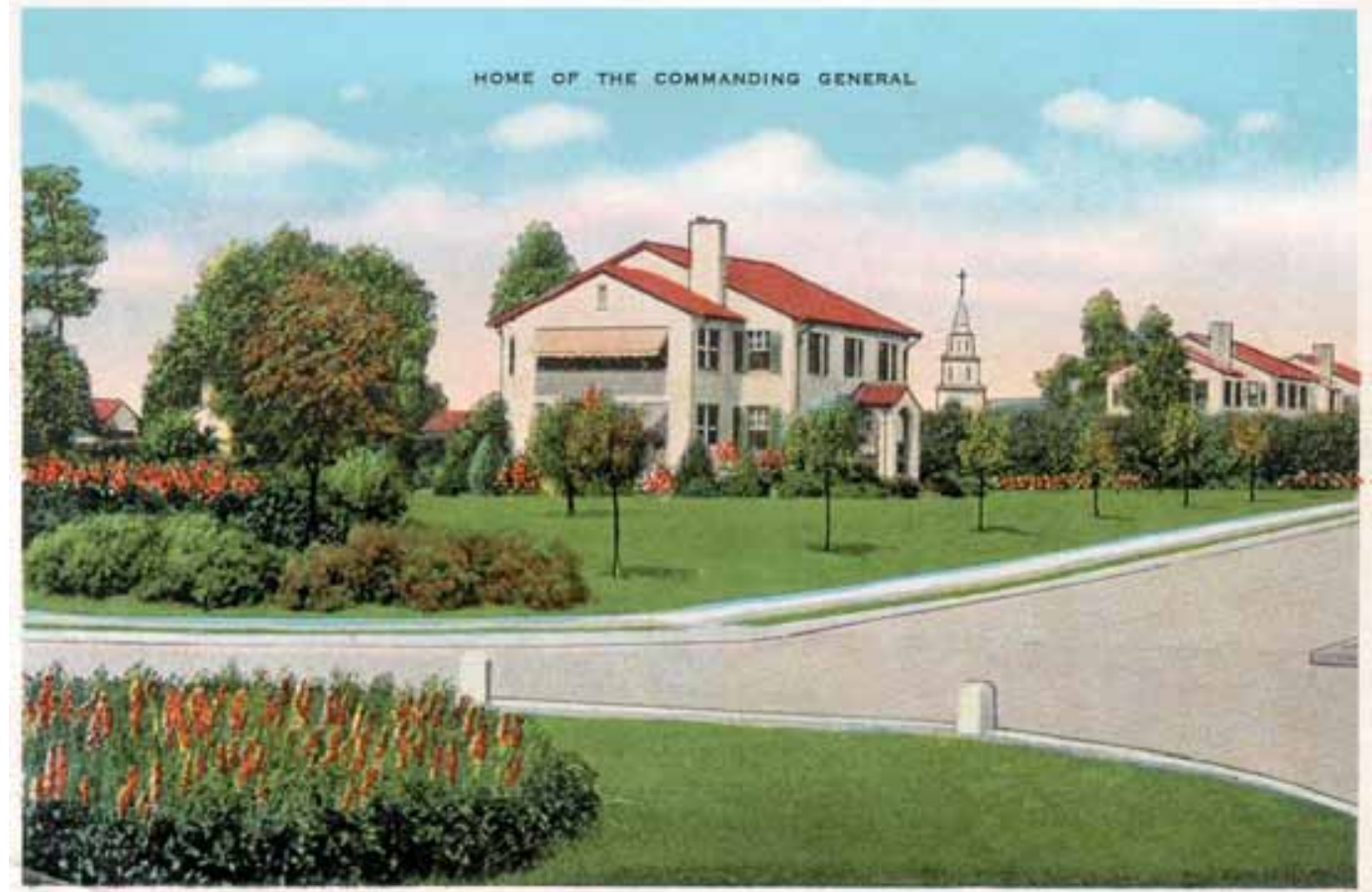

Figure 45. Postcard illustrating the house of the commanding general, 1940s (Fort Bragg Cultural Resources).

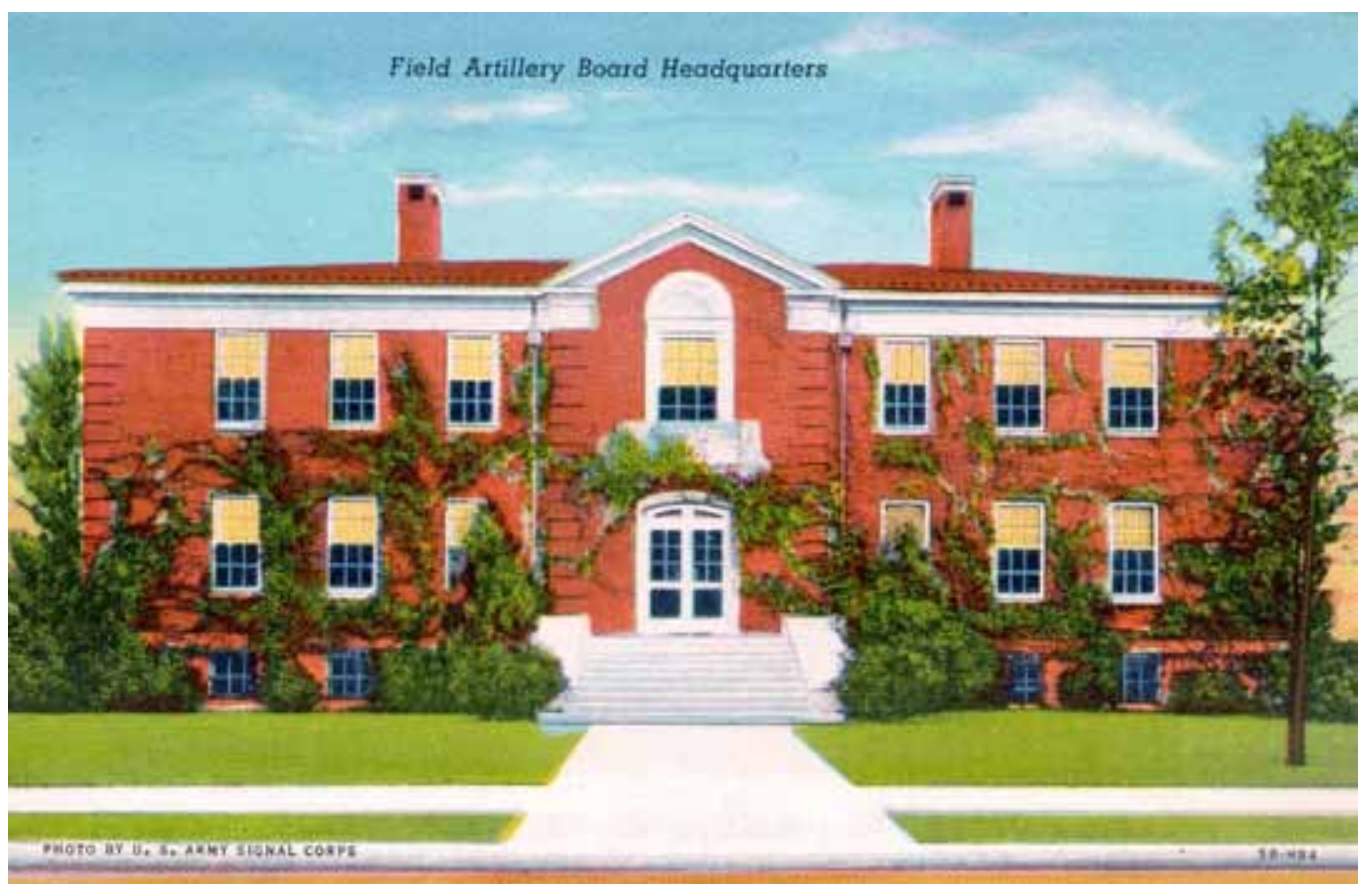

Figure 46. Postcard showing the vegetation around the Field Artillery Board Headquarters, 1930s (Fort Bragg Cultural Resources). 


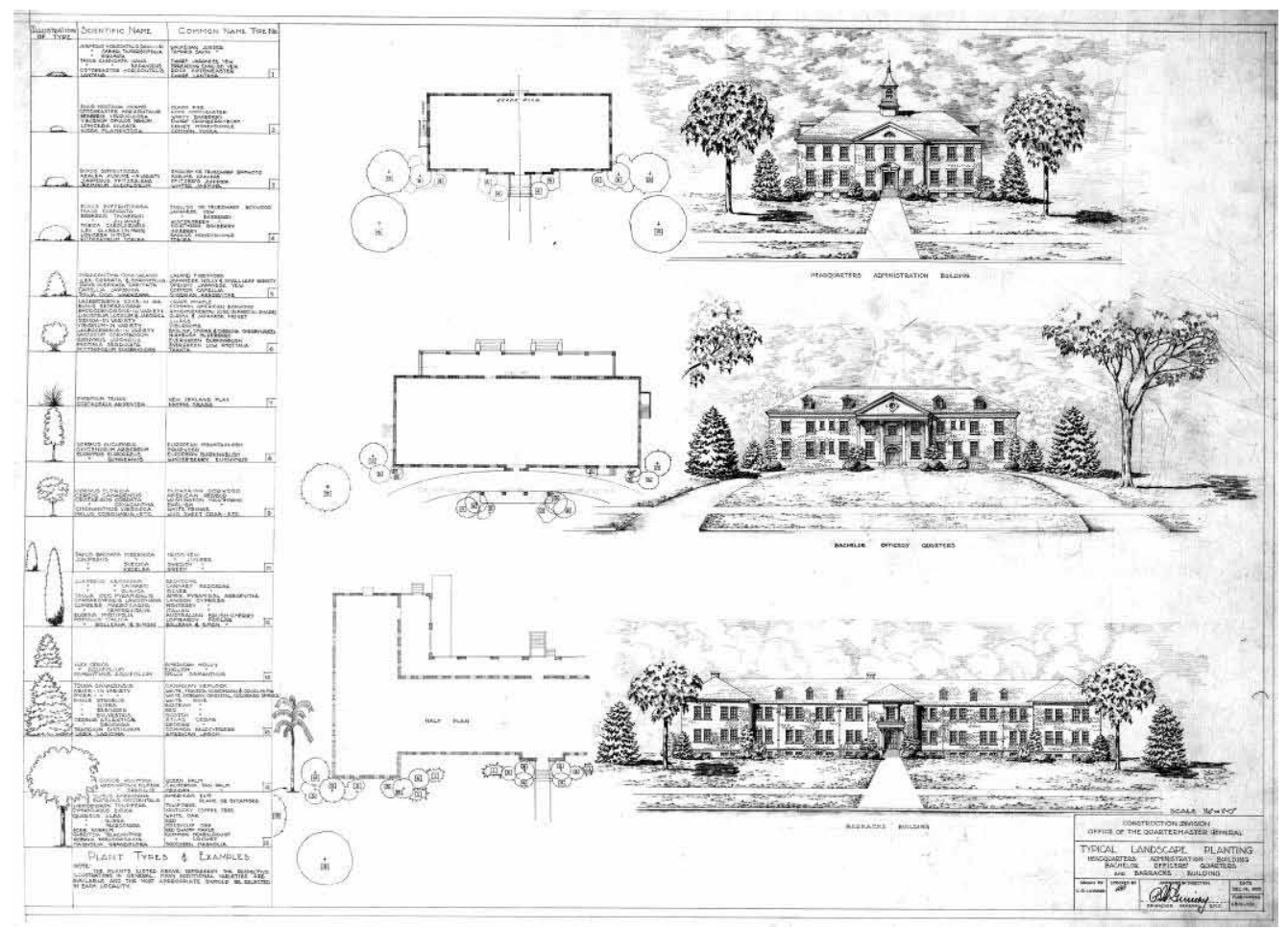

Figure 47. 1933 standardized planting plans for headquarters, bachelor officers' quarters, and barracks (Fort Bragg Cultural Resources).

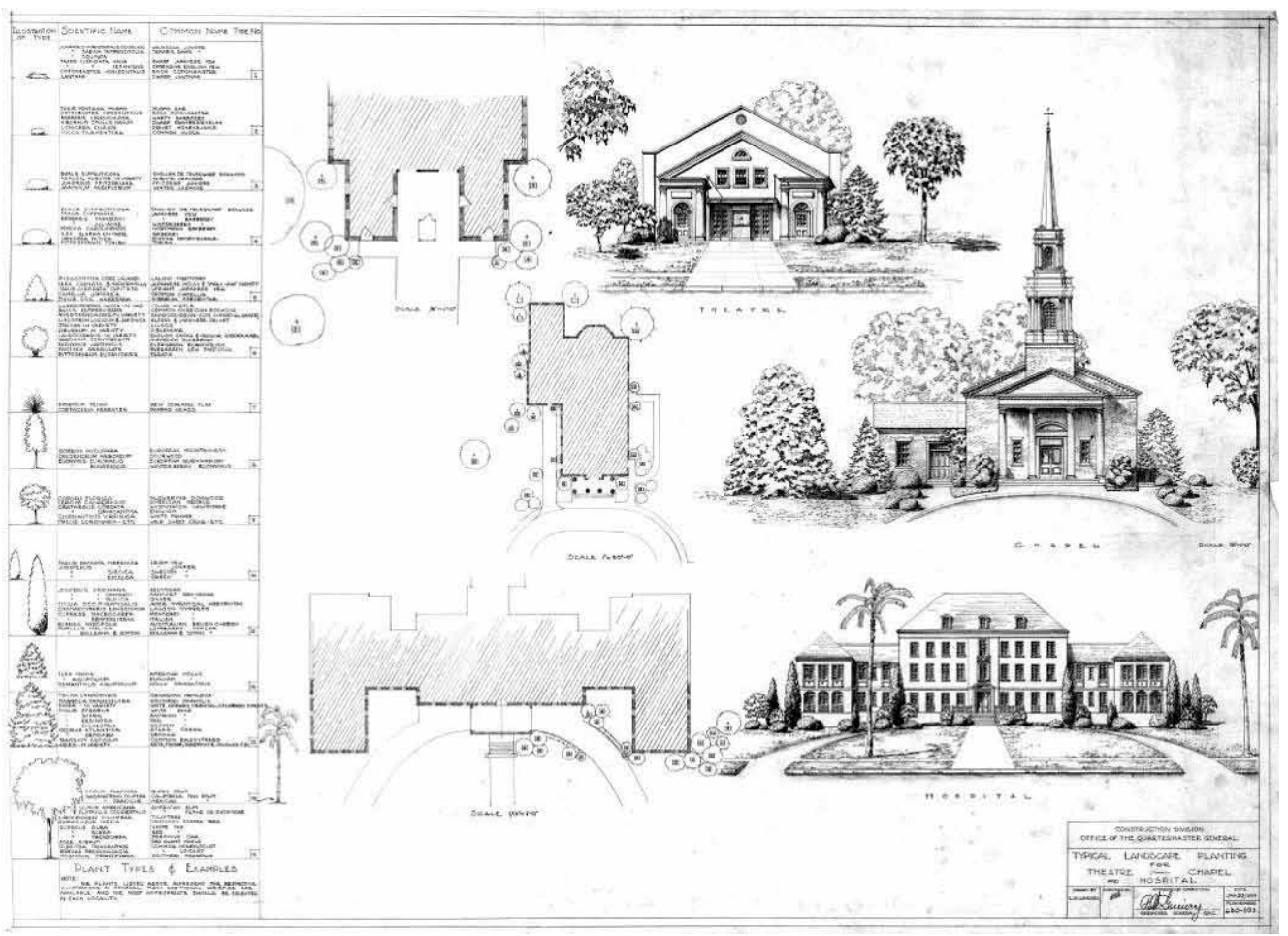

Figure 48. 1933 standardized planting plans for theater, chapel, and hospital (Fort Bragg Cultural Resources). 


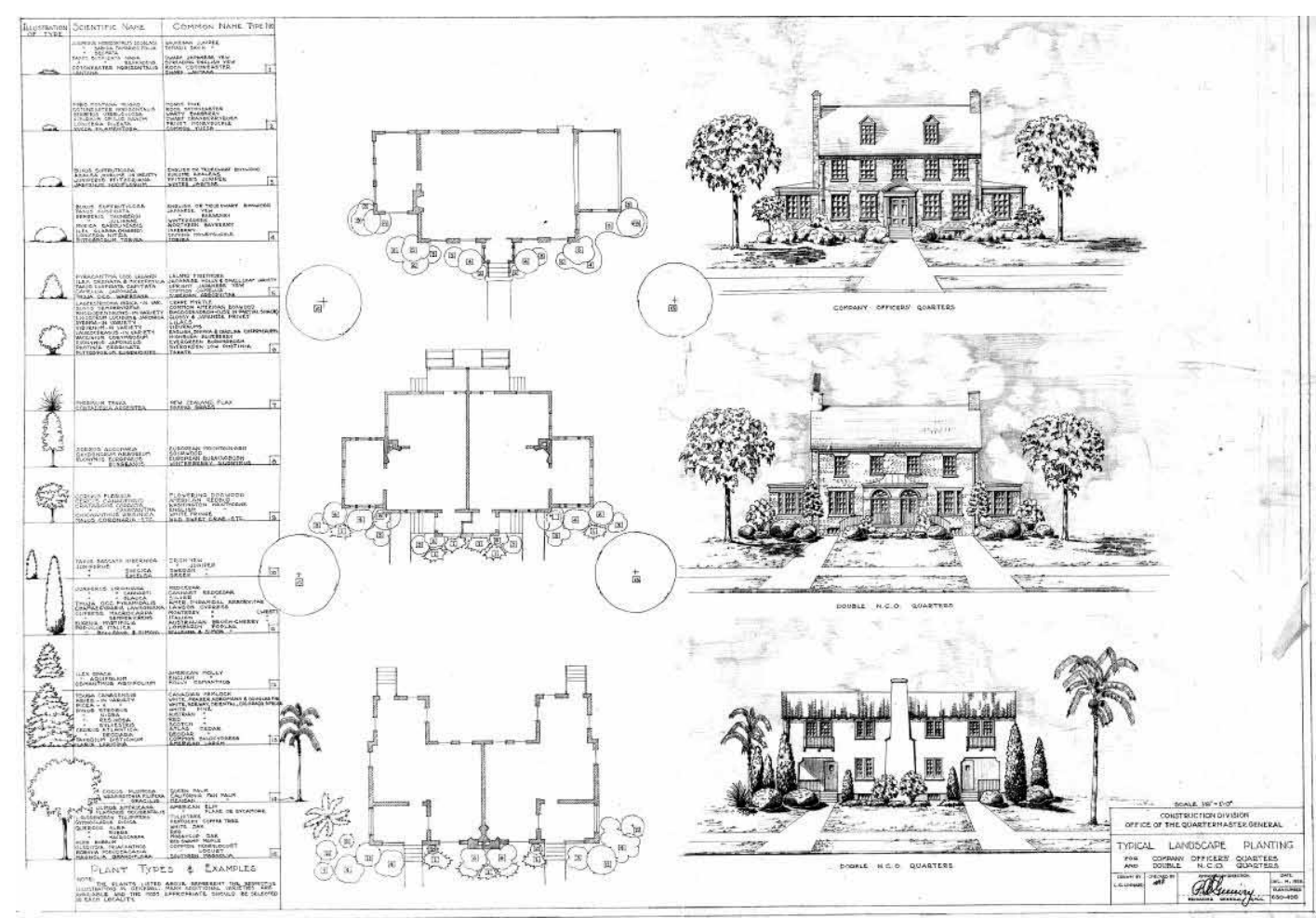

Figure 49. 1933 standardized planting plans for Company Officers' quarters and double NCO quarters (Fort Bragg Cultural Resources).

\section{Small-Scale Features}

The small-scale features of a site are objects with significance thoughtfully arranged in the landscape; they can range in size, be stationary or moveable, and they often contribute to the historic character of the installation (Loechl et al. 1996, p 90). Some examples of these features are monuments, light poles, benches, flagpoles, fencing, or signs and can be functional or purely decorative.

At Fort Bragg an important small-scale feature is the Iron Mike statue. Prominently located in the traffic circle at the intersection of Armistead and Randolph Streets, the sculpture of Iron Mike honors all airborne troopers. Completed in 1961 the statue was placed at the southern entrance to Fort Bragg on Bragg Boulevard. The artist of the piece, Leah Hiebert, designed the original landscaping around the statue. In 1979 Iron Mike was moved to the traffic circle, a more prominent location within the cantonment (Figure 50). 


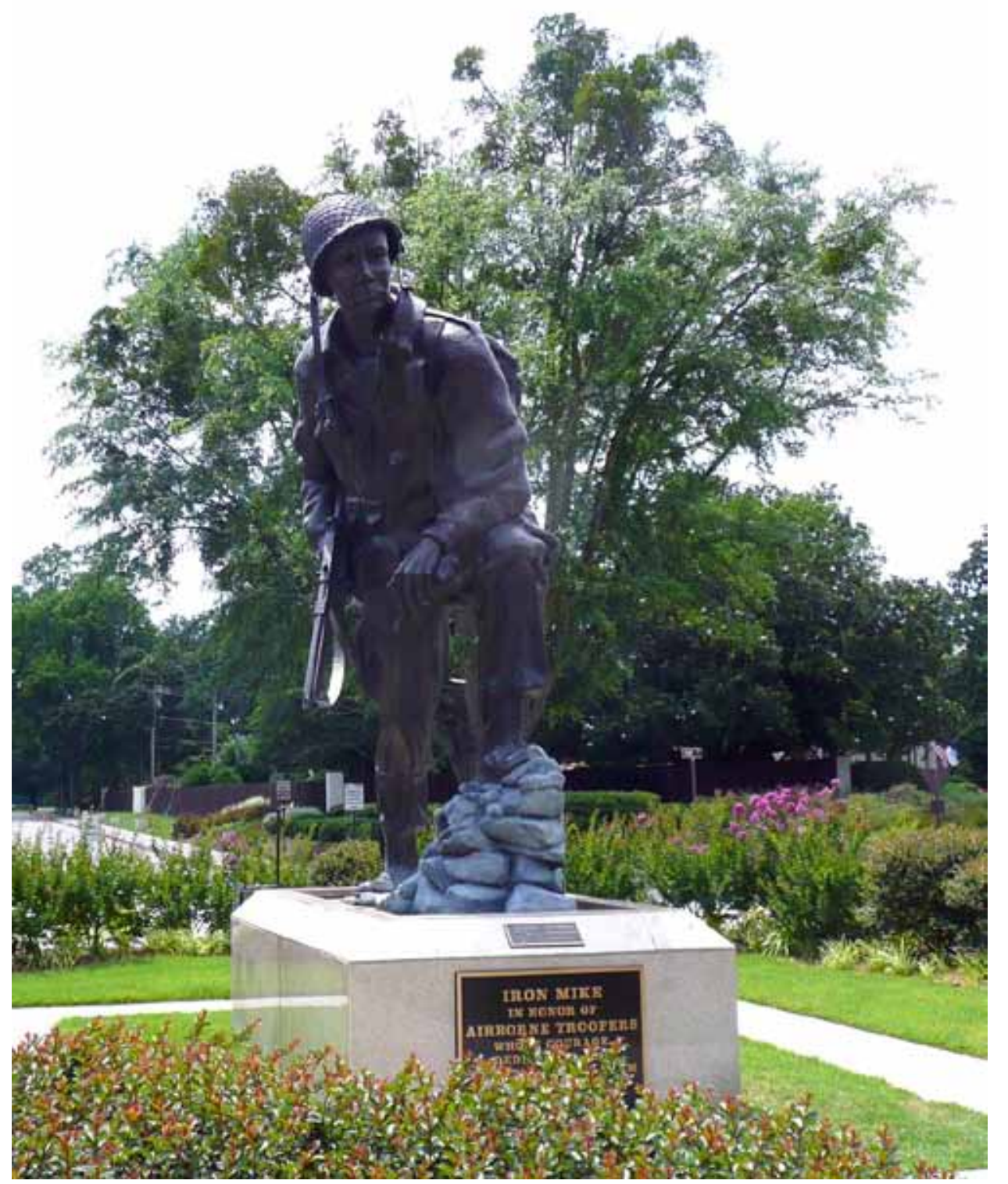

Figure 50. Iron MikeSculpture, 2009 (ERDC-CERL).

Another significant small-scale feature of Fort Bragg's OPHD is the flagpole. The flagpole is prominently located in the eastern point of the parade field. The area is bounded with plantings and monuments emphasizing its ceremonial and aesthetic importance. These commemorative objects and the flagpole are representations of the military's values of pride and patriotism further defining the cultural landscape at Fort Bragg (Figures 51 and 52). Appendix A includes a more comprehensive list of features. 


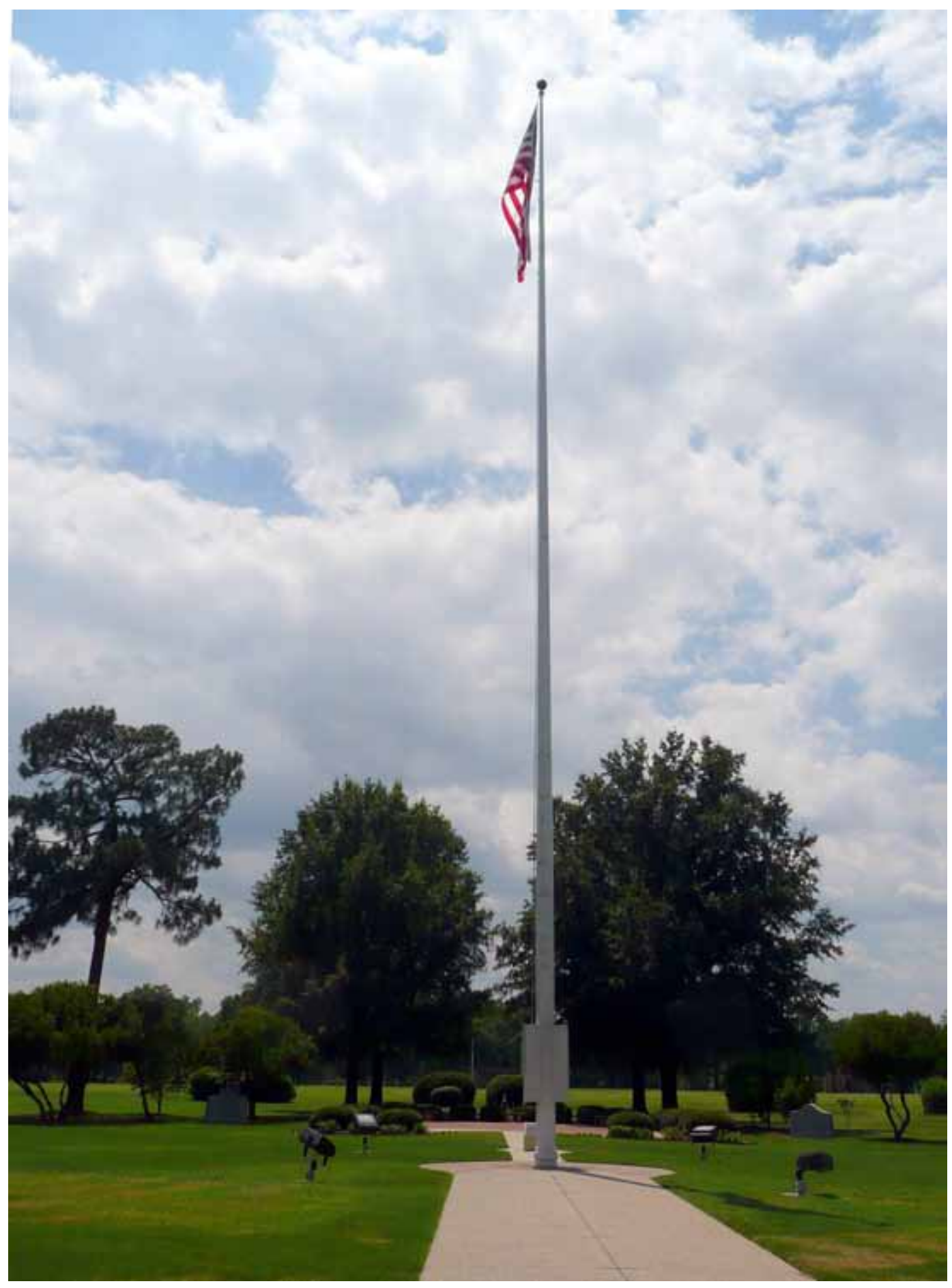

Figure 51. Flag pole looking west toward parade field, 2009 (ERDC-CERL). 

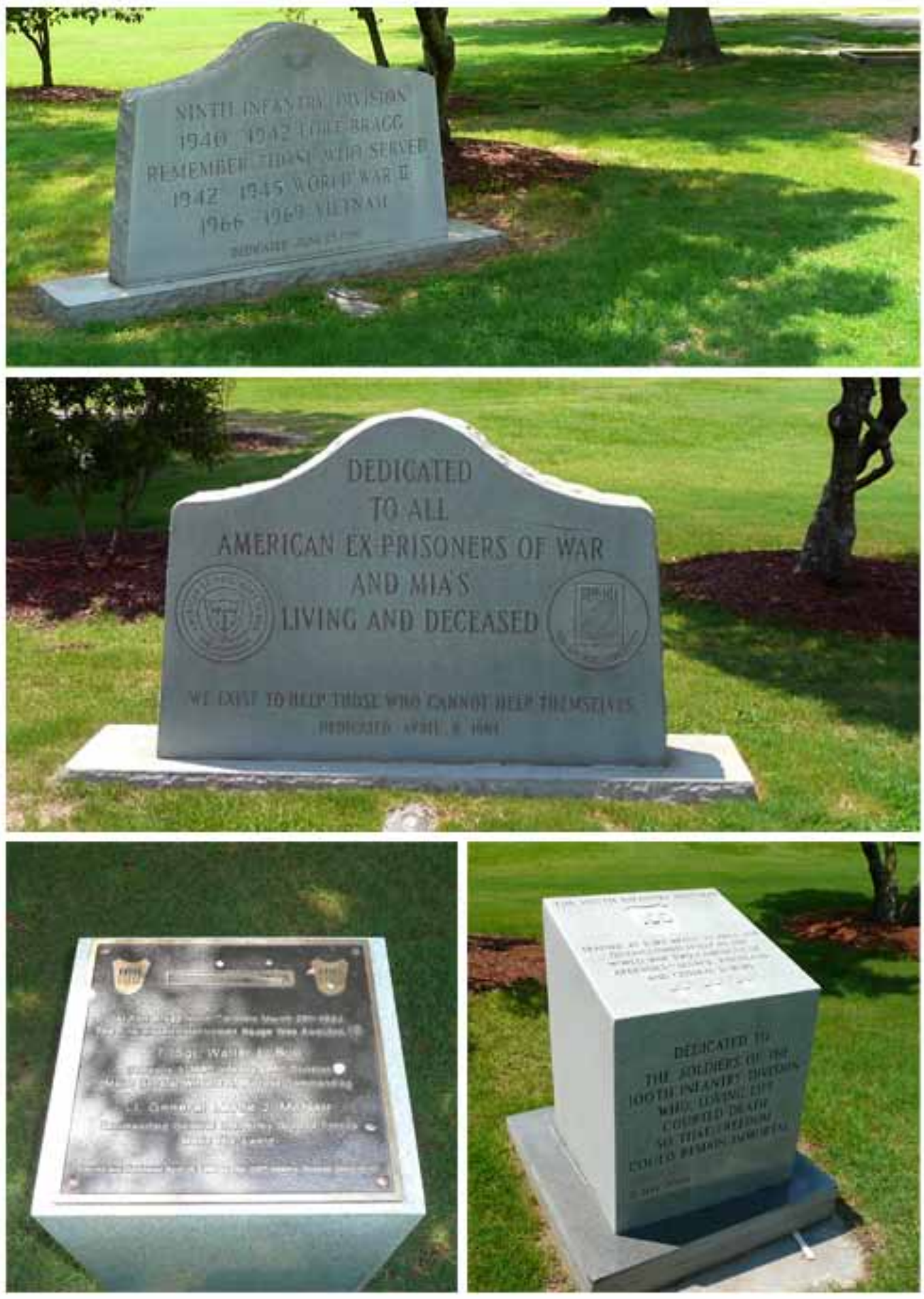

Figure 52. Several of the memorials around the flagpole area, 2009 (ERDC-CERL).Evaluation 


\section{Evaluation}

\section{General}

The NRHP defines historic districts as areas possessing a significant concentration, linkage, or continuity between site, buildings, structures, and objects historically or aesthetically united by design, planning, or physical development. At Fort Bragg, architectural surveys in 1996 and 2001 identified the boundaries of the OPHD and found it eligible for inclusion on the NRHP. The district was determined to form an architecturally cohesive unit significant under Criterion A for its role in military history and under Criterion $\mathrm{C}$ for its characteristics of Army planning and architecture during the Interwar Period (Little 2001). The OPHD encompasses approximately 520 acres containing 300 contributing resources of which 298 are buildings or structures, and two recreational landscapes (Fort Bragg Directorate of Public Works 2007, p 11;Fort Bragg Cultural Resources 2010). Additionally, there are 95 noncontributing buildings and structures in the historic district. The significant historic period of the district is from 19181945. This report examines the landscapes of the OPHD and discusses management strategies for the landscapes that are significant and contributing to the historic character of the area.

For a property to be eligible for inclusion on the NRHP it must meet several criteria that illustrate its historic significance. The NRHP lists four Criteria for Evaluation establishing significance through a property's association with historically important events, persons, design and construction, or information potential. The following are brief descriptions of each of the four Criteria:

Criteria A. Event - is associated with events that have made a significant contribution to the broad patterns of our history.

Criteria B. Person-is associated with the lives of persons significant in our past.

Criteria C. Design/Construction-embodies the distinctive characteristics of a type, period, or method of construction, or that represent the work of a master, or that possess high artistic values, or that represent a significant and distin- 
guishable entity whose components may lack individual distinction.

Criteria D. Information Potential-yielded, or is likely to yield, information important in prehistory or history (National Park Service 1991).

To supplement the Criteria for Evaluation, a property or district should be evaluated according to the NRHP's seven categories of historical integrity. The categorizations of integrity enable the identification and codification of elements within a property that contribute to its overall historical character. These elements reflect the property's period of significance and clearly convey its historical connections. The seven categories used to determine integrity in the NRHP evaluation process are:

\section{Location}

Location is the place where the historic property was constructed or the place where the historic event occurred.

\section{Design}

Design is the combination of elements that create the form, plan, space, structure, and style of a property. It results from conscious decisions made during the original conception and planning of a property (or its significant alteration) and applies to activities as diverse as community planning, engineering, architecture, and landscape architecture. Design includes such elements as organization of space, proportion, scale, technology, ornamentation, and materials.

\section{Setting}

Setting is the physical environment of a historic property. Setting refers to the character of the place in which the property played its historical role. It involves how, not just where, the property is situated and its relationship to surrounding features and open space.

\section{Materials}

Materials are the physical elements that were combined or deposited during a particular period of time and in a particular pattern or configuration to form an historic property. 


\section{Workmanship}

Workmanship is the physical evidence of the crafts of a particular culture or people during any given period in history or prehistory.

\section{Feeling}

Feeling is a property's expression of the aesthetic or historic sense of a particular time period.

\section{Association}

Association is the direct link between an important historic event or person and an historic property (National Park Service 1991).

These classifications of historical integrity provide the justification for a property or district to be determined eligible for the National Register of Historic Places. In this report, these classifications were used to evaluate and determine the significance of Fort Bragg's OPHD landscapes.

\section{Findings}

The OPHD is defined as the area of the 1918-1919 WWI construction plus the growth of the cantonment during the interwar and WWII years, roughly 1927-1940 and 1941-1945.

Few WWI-era buildings remain from Camp Bragg; however, the 1918 layout is strongly evident in the landscape. Most of the buildings in the OPHD were built during the interwar years after Camp Bragg became a permanent Army post in 1922. The majority of the interwar structures were built between 1927 and 1940. Construction in the OPHD throughout WWII largely consisted of temporary offices and barracks with the exception of the Red Cross Building built in 1942. The OPHD is characterized by two architectural styles as well as the distinct chevron layout and linear organization of the site.

Although Fort Bragg's OPHD has never officially been listed on the National Register of Historic Places, a nomination determined the district was eligible in 1996. There are currently 298 contributing structures in the historic district, of these 209 are historic Army Family Housing units in Normandy Heights and Bastogne Gables. A few buildings in the historic district were constructed after WWII; however, they do not adversely af- 
fect the historic integrity of the district. Because the layout, transportation networks, land use, building densities, and vegetation patterns have not changed significantly since the period of historic significance, the OPHD retains much of its interwar era integrity.

The historic integrity of the OPHD is derived from the spatial relationships between buildings and open spaces (Figures 53- 55). The layout and organization of roads, parking lots, and buildings create a network of open spaces that defines interwar era military camp planning. Based on the Beaux Arts style of city planning, the layout of Camp Bragg is based on distinct geometries reinforcing the construction of the built environment. These open spaces contribute significantly to the character of the OPHD and preserving them as unbuilt and mostly vegetated is essential to maintaining the historic visual and spatial relationships of the district. Even though parking in the OPHD is limited, historic open spaces should not be converted to parking lots. Table 1 lists the contributing open spaces and their relationship to the historic landscape, and landscapes found to significantly contribute to the historic character of the OPHD.

These landscapes were deemed historically significant because they possess some or all of the National Register's seven aspects of integrity through their location, design, workmanship, association, feeling, setting, and materials.

Chapter 5 includes recommendations to preserve the landscapes of the OPHD; these recommendations focus on the preserving the historic layout, vegetation patterns, and views while also proposing management strategies and suggestions for future growth. 


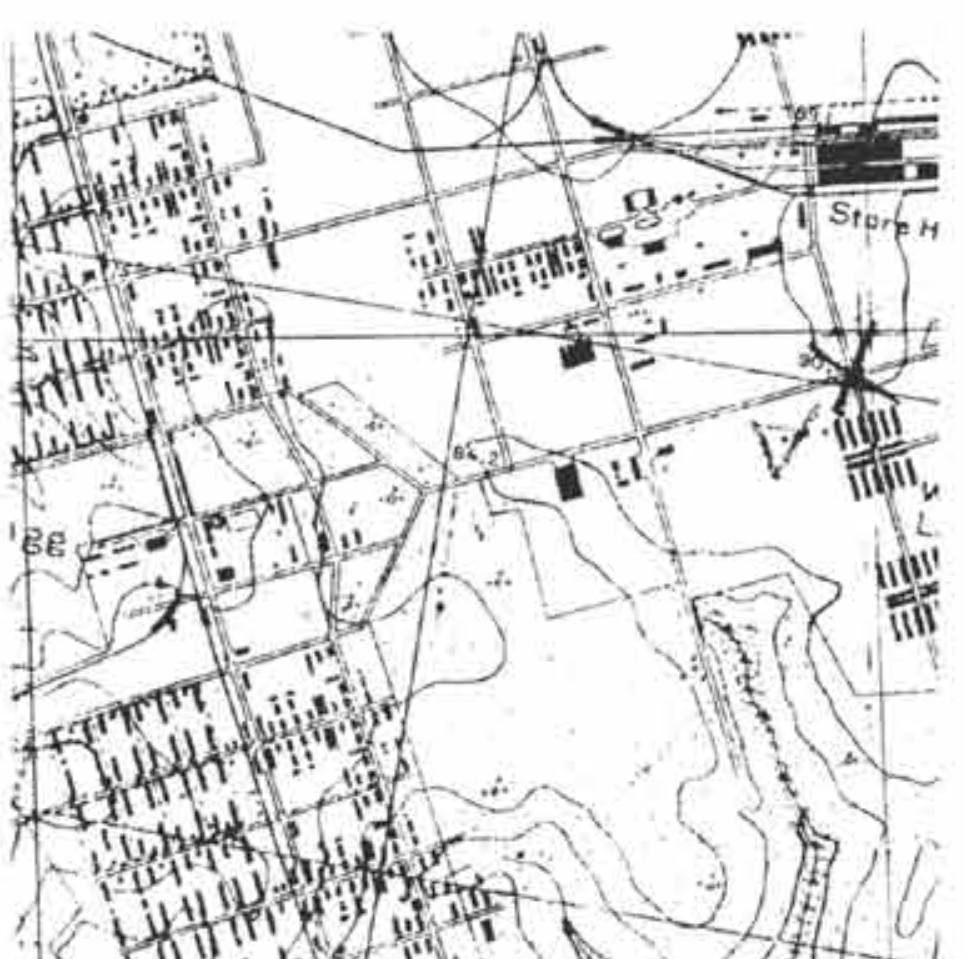

1918-1919

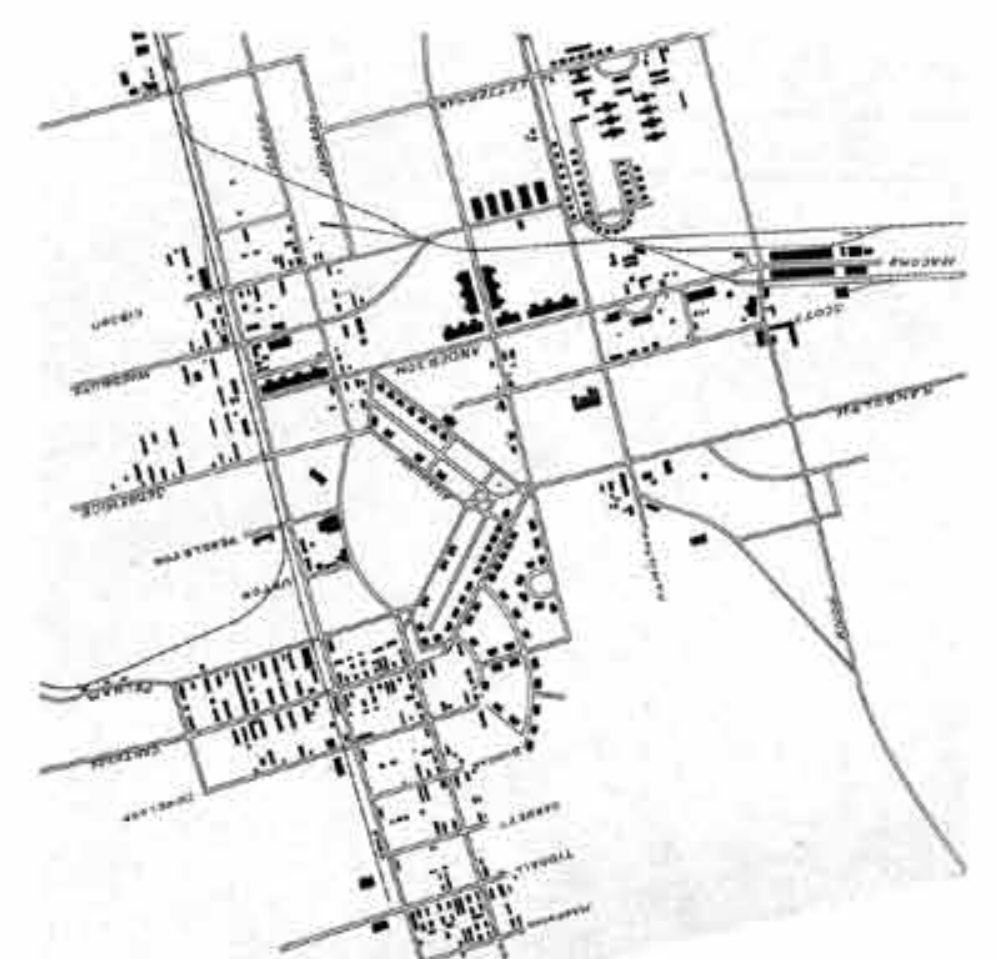

1930

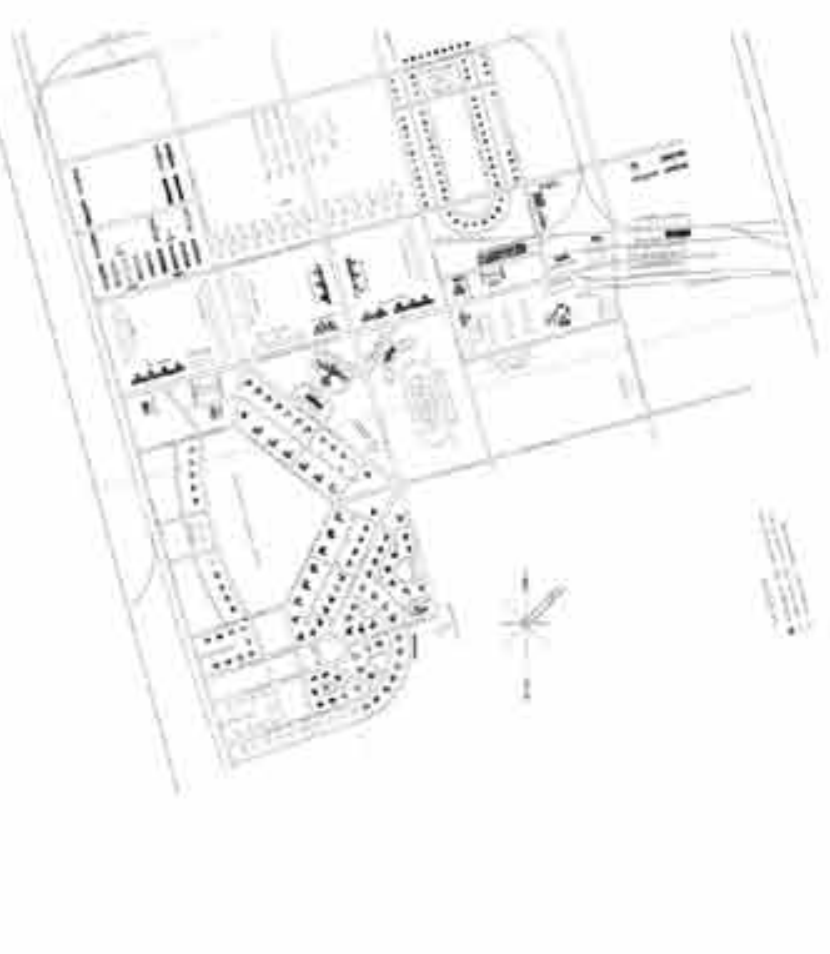

1935

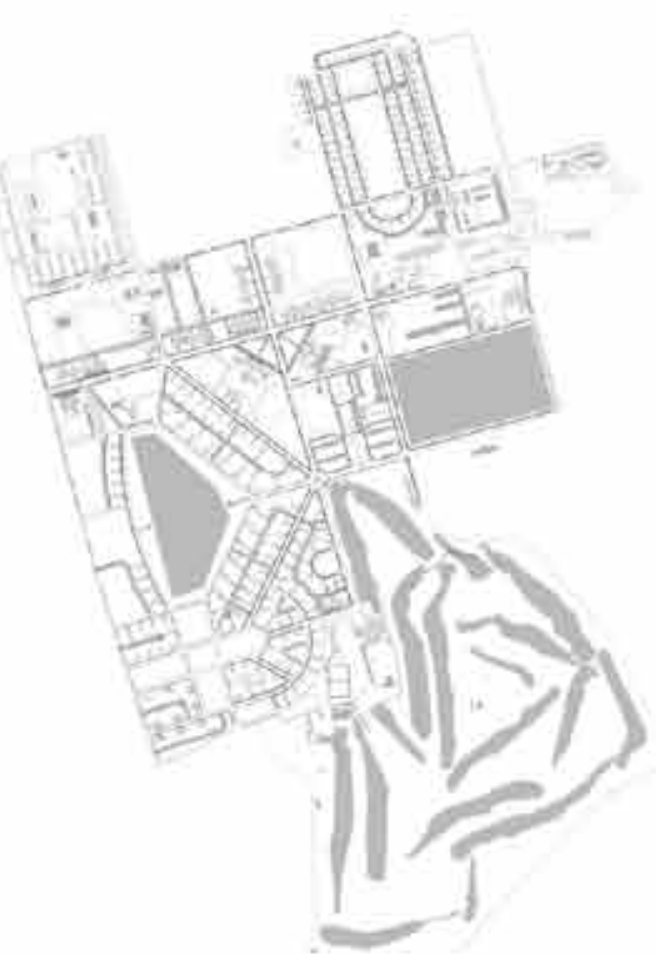

2009

Figure 53. Layout development of the present-day OPHD (Fort Bragg Cultural Resources). 



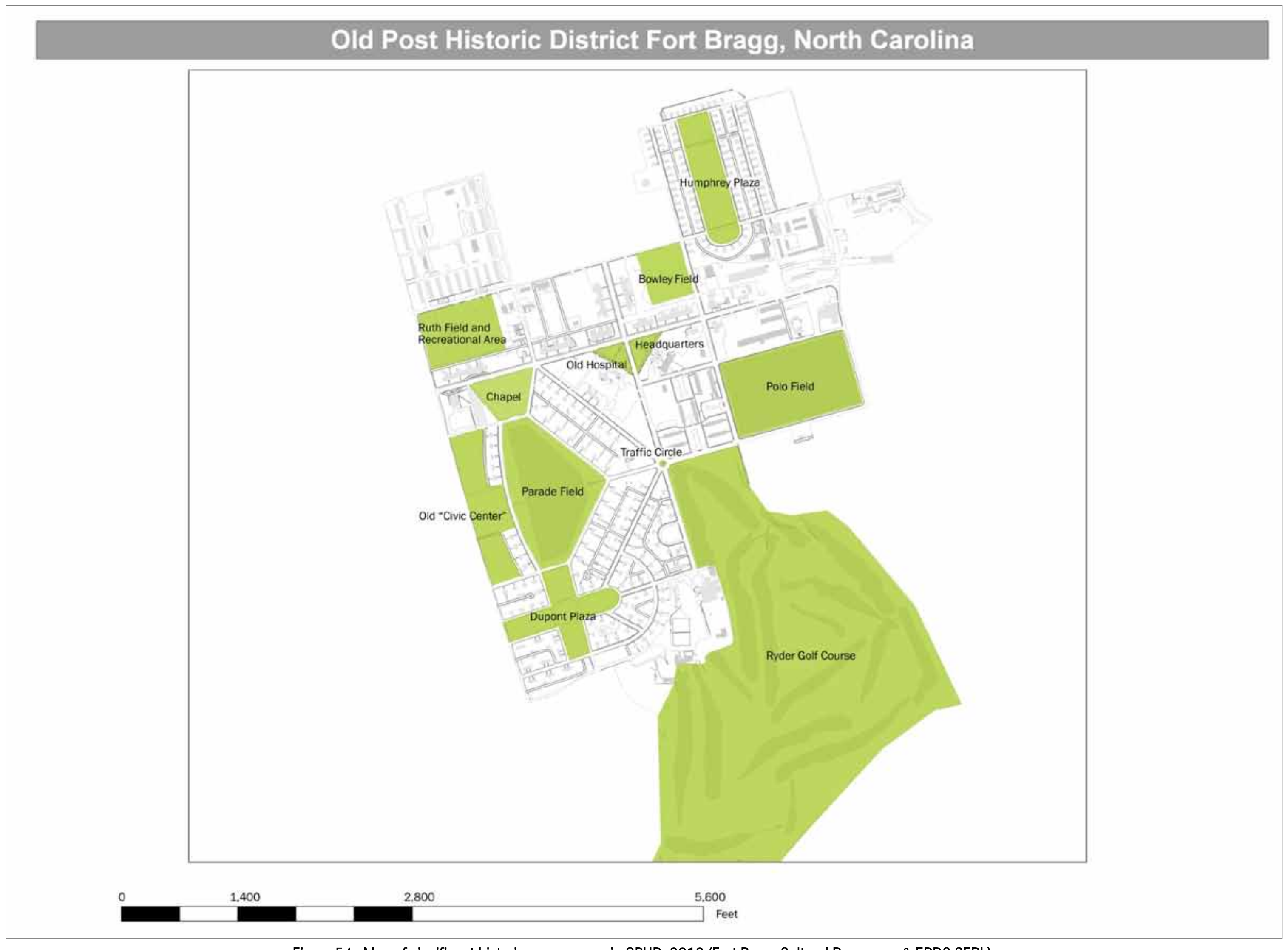

Figure 54. Map of significant historic open spaces in OPHD, 2010 (Fort Bragg Cultural Resources \& ERDC-CERL). 


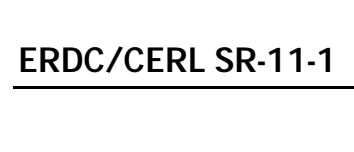




\section{Old Post Historic District Fort Bragg, North Carolina}

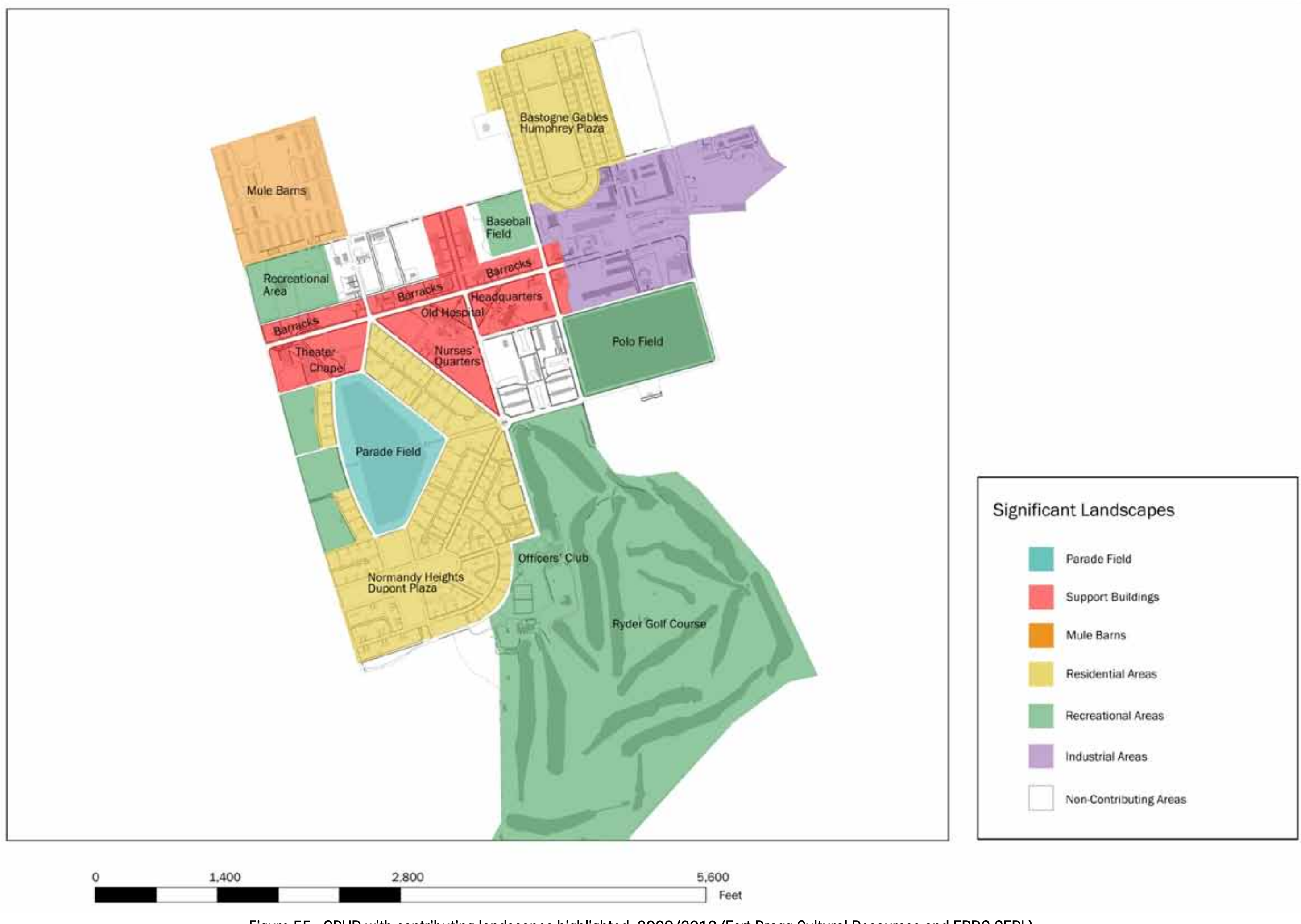

Figure 55. OPHD with contributing landscapes highlighted, 2009/2010 (Fort Bragg Cultural Resources and ERDC-CERL). 

Table 1. Contributing landscapes and their historic significance.

\begin{tabular}{|c|c|c|c|}
\hline $\begin{array}{l}\text { Contributing } \\
\text { Landscapes }\end{array}$ & Historical Significance & Character-Defining Features & NRHP Eligibility \\
\hline Parade Field & $\begin{array}{l}\text { Ceremonial space for reviews and } \\
\text { parades. }\end{array}$ & $\begin{array}{l}\text { - Interwar era BeauxArts } \\
\text { cantonment layout in re- } \\
\text { sponse to } 1918 \text { camp } \\
\text { layout. } \\
\text { - Layout in response to main } \\
\text { circulation routes like Ran- } \\
\text { dolph Street and Reilly } \\
\text { Street. } \\
\text { - Centrally located, chevron- } \\
\text { shaped. }\end{array}$ & Contributing \\
\hline Normandy Heights & $\begin{array}{l}\text { Originally established as Officers' } \\
\text { housing. }\end{array}$ & $\begin{array}{l}\text { - Part of the interwar era } \\
\text { Beaux Arts layout. }\end{array}$ & Contributing \\
\hline Dupont Plaza & $\begin{array}{l}\text { Central open space for the health } \\
\text { and welfare of the residents Nor- } \\
\text { mandy Heights neighborhood. }\end{array}$ & $\begin{array}{l}\text { - Part of the interwar Beaux } \\
\text { Arts cantonment layout. }\end{array}$ & Contributing \\
\hline $\begin{array}{l}\text { Traffic circle at the } \\
\text { intersection of } \\
\text { Adams, Randolph, } \\
\text { Dyer, and Armistead } \\
\text { Streets }\end{array}$ & $\begin{array}{l}\text { Has always been a prominent } \\
\text { space for displaying significant } \\
\text { memorials and monuments. }\end{array}$ & $\begin{array}{l}\text { - Layout in response to main } \\
\text { circulation routes like Ran- } \\
\text { dolph Street and Reilly } \\
\text { Street. } \\
\text { - Part of the interwar era } \\
\text { BeauxArts cantonment } \\
\text { layout. }\end{array}$ & Contributing \\
\hline $\begin{array}{l}\text { Area west of the Pa- } \\
\text { rade Field where } \mathrm{WM} \\
\text { temporary officers } \\
\text { club was located }\end{array}$ & $\begin{array}{l}\text { Historically was part of the "civic } \\
\text { core" of the cantonment, now } \\
\text { serves as a buffer between Reilly } \\
\text { Street and Normandy Heights. }\end{array}$ & $\begin{array}{l}\text { - Layout in response to main } \\
\text { circulation routes like Reilly } \\
\text { Street. } \\
\text { - Part of the interwar era } \\
\text { Beaux Arts cantonment } \\
\text { layout. }\end{array}$ & Contributing \\
\hline Bastogne Gables & $\begin{array}{l}\text { Originally established as NCO } \\
\text { housing. }\end{array}$ & $\begin{array}{l}\text { - Part of the interwar era } \\
\text { Beaux Arts cantonment } \\
\text { layout. }\end{array}$ & Contributing \\
\hline Humphrey Plaza & $\begin{array}{l}\text { Bastogne Gables neighborhood } \\
\text { organized around central park for } \\
\text { the health and welfare of the resi- } \\
\text { dents. }\end{array}$ & $\begin{array}{l}\text { - Part of the interwar era } \\
\text { Beaux Arts cantonment } \\
\text { layout. }\end{array}$ & Contributing \\
\hline Polo Field & $\begin{array}{l}\text { Field has always been dedicated to } \\
\text { recreational purposes. }\end{array}$ & $\begin{array}{l}\text { - Interwar era Beaux Arts } \\
\text { cantonment layout in re- } \\
\text { sponse to } 1918 \text { camp } \\
\text { layout. }\end{array}$ & Contributing \\
\hline Ryder Golf Course & $\begin{array}{l}\text { Since the early } 1930 \text { s, the golf } \\
\text { course has been a recreational } \\
\text { space. }\end{array}$ & $\begin{array}{l}\text { - Originally the officers' golf } \\
\text { course it was located adja- } \\
\text { cent to officers' housing. }\end{array}$ & Contributing \\
\hline Support Building Area & $\begin{array}{l}\text { Key buildings located prominently } \\
\text { to reflect the importance of the } \\
\text { buildings such as the chapel and } \\
\text { theater. }\end{array}$ & $\begin{array}{l}\text { - Part of the interwar era } \\
\text { Beaux Arts cantonment } \\
\text { layout. } \\
\text { - Built in two different archi- } \\
\text { tectural styles: Spanish Ec- } \\
\text { lectic and Georgian Revival. }\end{array}$ & Contributing \\
\hline
\end{tabular}




\begin{tabular}{|l|l|l|l|}
\hline $\begin{array}{l}\text { Contributing } \\
\text { Landscapes }\end{array}$ & Historical Significance & Character-Defining Features & NRHP Eligibility \\
\hline Bowley Field & $\begin{array}{l}\text { Has long been dedicated to recrea- } \\
\text { tional purposes. }\end{array}$ & $\begin{array}{l}\text { B Baseball fields were impor- } \\
\text { tant recreational space in } \\
\text { the barracks complex. }\end{array}$ & Contributing \\
\hline Ruth Field & $\begin{array}{l}\text { Has long been dedicated to recrea- } \\
\text { tional purposes. }\end{array}$ & $\begin{array}{l}\text { Baseball fields were impor- } \\
\text { tant recreational space in } \\
\text { the barracks complex. }\end{array}$ & Contributing \\
\hline $\begin{array}{l}\text { Area surrounding the } \\
\text { chapel }\end{array}$ & $\begin{array}{l}\text { Has always been an open space } \\
\text { providing a buffer between reli- } \\
\text { gious and military ceremony. }\end{array}$ & $\begin{array}{l}\text { Part of the interwar era } \\
\text { Beaux Arts cantonment } \\
\text { layout. }\end{array}$ & Contributing \\
\hline $\begin{array}{l}\text { Triangular areas in } \\
\text { front of the old hos- } \\
\text { pital and headquar- } \\
\text { ters buildings }\end{array}$ & $\begin{array}{l}\text { Spatially signified the importance } \\
\text { of the hospital and headquarters } \\
\text { in the cantonment. }\end{array}$ & $\begin{array}{l}\text { Part of the interwar era } \\
\text { Beaux Arts cantonment } \\
\text { layout. }\end{array}$ & Contributing \\
\hline Mule Barn Area & Support area for field artillery. & $\begin{array}{l}\text { Part of the interwar era } \\
\text { Beaux Arts cantonment } \\
\text { layout. }\end{array}$ & Contributing \\
\hline Industrial Area & $\begin{array}{l}\text { Has been important manufacturing } \\
\text { and support space in the OPHD. }\end{array}$ & $\begin{array}{l}\text { Part of the interwar era } \\
\text { Beaux Arts cantonment } \\
\text { layout. }\end{array}$ & Contributing \\
\hline
\end{tabular}




\section{Historic District Recommendations}

\section{Overall District}

Historic Characteristics:

- The Fort Bragg cantonment was laid out on two axes: Reilly Road, running north and south and Randolph Street (the entrance road), running east and west (Figure 56). The parade field is located where these would intersect and is surrounded with officers' quarters. This area formed what was known as the "civic center" of the post where the chapel and theater were located.

- North of Randolph Street was the administrative core of Fort Bragg. Here, the former post Headquarters, hospital, and barracks line Macomb Street with other administrative buildings clustered along side streets.

- Streets around the historic district are linear; the resulting geometries convey the order and hierarchy of military culture. The pattern of streets also delineates the original Beaux Arts style plan for the cantonment.

- The use of parade fields, parks, and the wide, tree lined roads give the district a suburban feel. This is in contrast to other areas of the post where uniformity, rectilinear layouts, and a lack of ornamentation are typical.

- Architectural continuity in the district is conveyed through the repetition of two types of architectural styles; the Georgian Revival, used for the administrative buildings, and the Spanish Eclectic, used for the neighborhood areas.

\section{Existing Conditions}

Currently the OPHD retains much of its historic character of the original, Beaux Arts plan. The strong geometries of the axial design have organized the buildings of the cantonment providing the district with a distinct form. This form is further emphasized by the two architectural styles chosen for the district, as well as the vegetation patterns throughout. Although some elements of the historic district have been modified, these changes have not significantly altered the original layout or architectural styling of the district. 


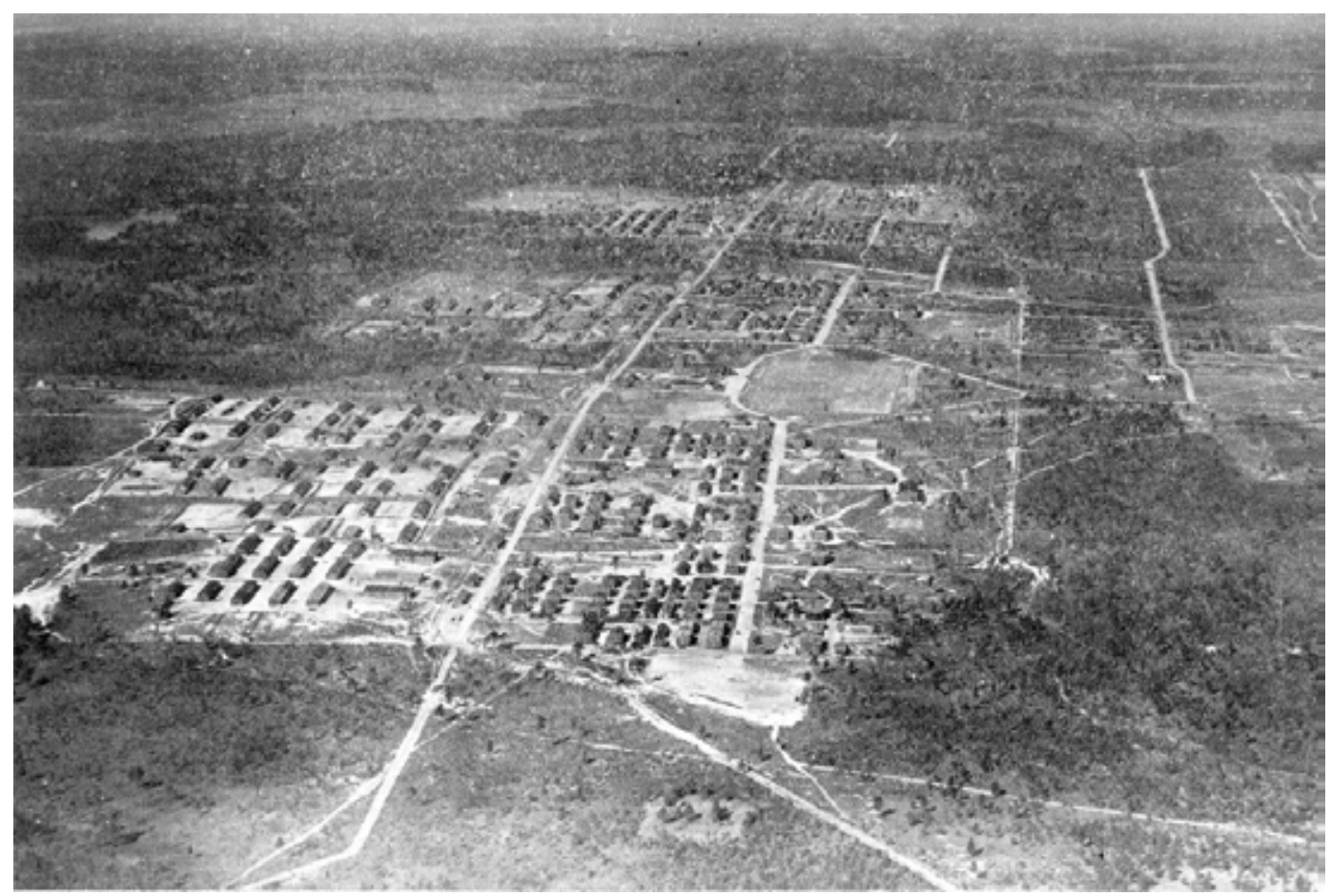

Figure 56. Aerial view of the original layout of the OPHD looking north, 1920s (Fort Bragg Cultural Resources).

The open spaces are important to the suburban and park-like character of the historic district. Ceremonial and recreational areas have retained their purposes remaining open and unobstructed. The streets in the OPHD are framed with mature trees spatially emphasizing the hierarchy of the original layout of roads. Currently the vegetation in the historic district is not of uniform type, scale, or state of maintenance. While this does detract from the intentions of the original design the following recommendations will reinforce the historic landscapes of the OPHD.

\section{Design Recommendations}

- Maintain the street trees throughout the district; if one is removed replace it with an in-kind species preserving the spacing and placement of trees. Add trees along roads within the historic district where there are currently none. Streets on the outskirts of the district should be planted with trees (Appendix B).

- Where specified, all areas should be, at least, minimally planted and well maintained. The quality and level of landscaping varies within the historic district from poor to quite good. This is not a function of hierarchy within the planting plan, but is rather due to pest and disease problems, lack of maintenance, or individual efforts. 
- The standardized planting plans from the 1930s should be consulted regarding the placement and scale of new vegetation in these areas (Appendix B). The original intent and character of the planting scheme should be retained. However, when possible replace with pest and disease free varieties or native plants (Appendix C).

- For visual continuity throughout the district, establish one or two natural mulch types and a uniform garden edging type to choose from.

- Small-scale features should be similar in their design, type, and color scheme. Examples of small-scale features include, street lighting, benches, and signage. Using a consistent array of these elements will give the district a unified appearance.

- New construction in the historic district should preserve the design intention of the original, 1920s layout for the cantonment. The fields and parks should remain open spaces and the street grid should not be altered (Figure 57). 


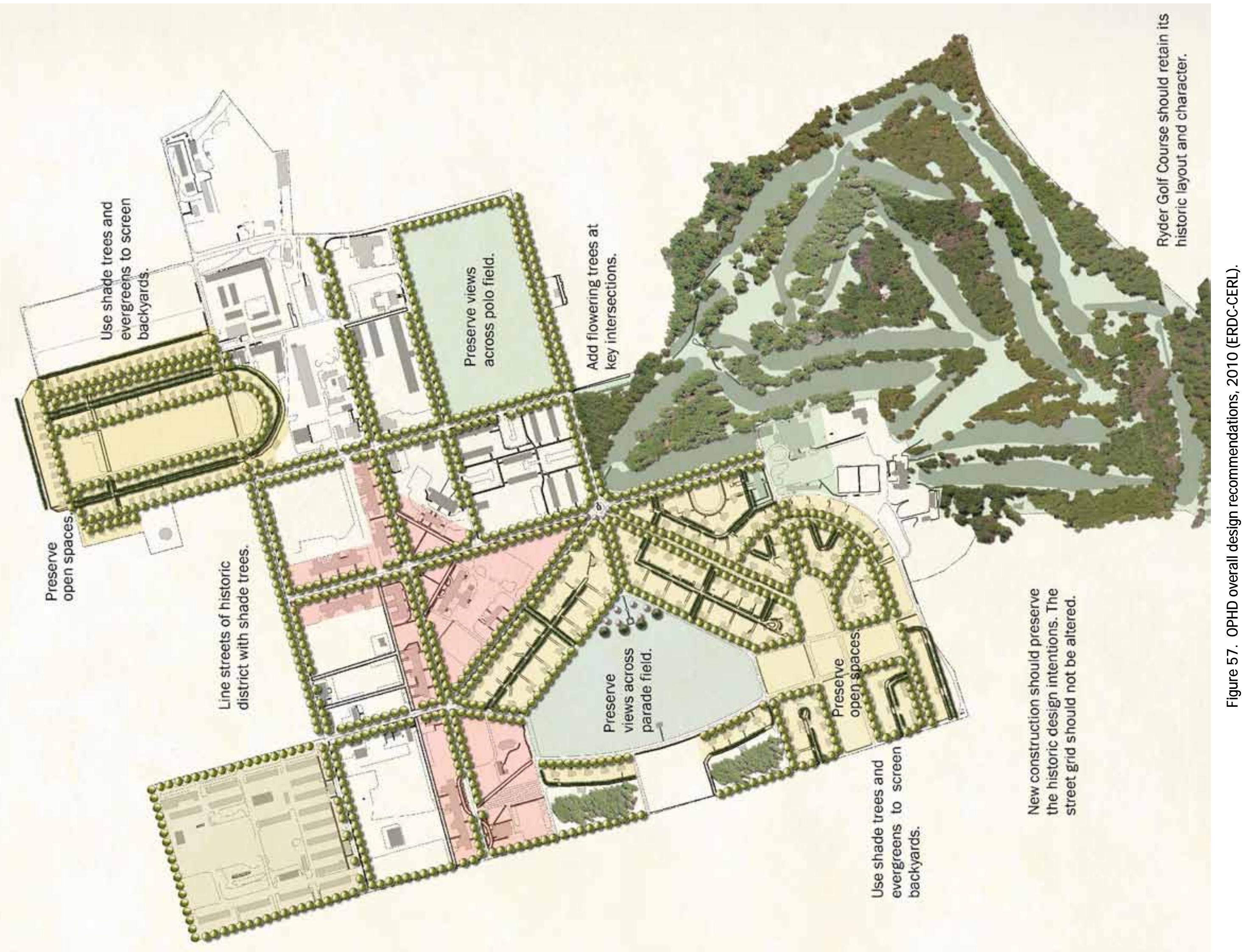





\section{Parade Field and Flagpole}

Historic Characteristics

- The parade field is centered where the two main axes of the cantonment plan intersect. In the original plan, this emphasizes the important, ceremonial function the parade field serves within a military installation.

- The parade field and flagpole are bounded by the chevron layout of the Normandy Heights neighborhood.

- The parade field was planned according to the 1920s Quartermaster Corps Construction Division's cantonment layout, which was based on the incorporation of open space to encourage healthy lifestyles.

- The parade field and the flagpole areas were originally formal, ceremonial spaces (Figure 58).

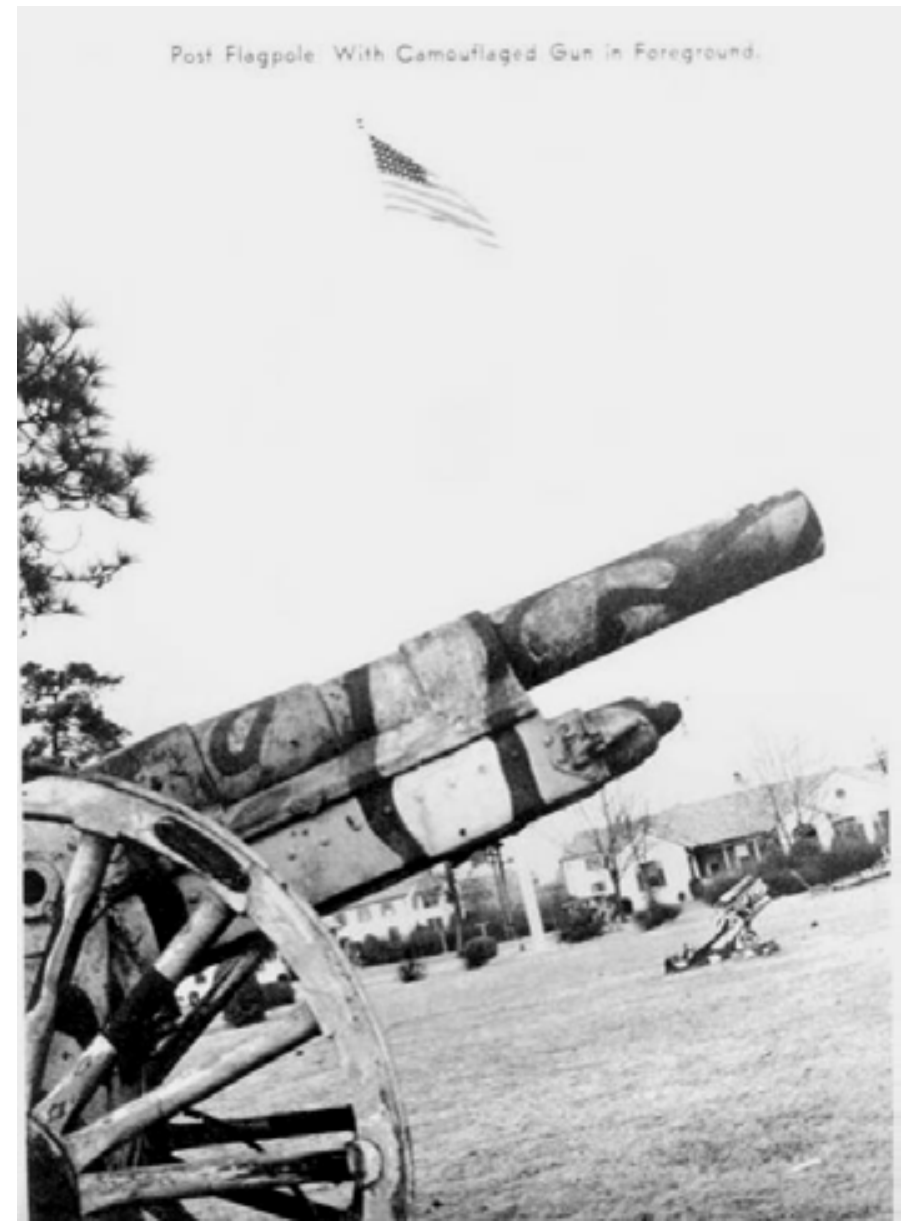

Figure 58. Parade field looking toward the Post Flagpole, 1941 (Fort Bragg Cultural Resources). 


\section{Existing Conditions}

The parade field at Fort Bragg lies at the center of the OPHD. The field is bounded on the east by the chevron layout of the Normandy Heights neighborhood and to the west by Capron Street. The perimeter is lined with deciduous trees and the space used for ceremonies is turf grass running north to south. At the north end of the field is the installation's chapel, serving as a focal point for the area. The flagpole is in the point of the chevron, surrounded by memorials. This space is separated from the parade field by a row of irregular, evergreen shrubs and is further enclosed with deciduous and pine trees.

The parade field retains its historic integrity. Unlike other military installations Fort Bragg has left the parade field an open ceremonial space and few changes have been made to the field or to the areas adjacent to the grounds. Although a review stand was built on the western edge in the 1970s (Figure 59), it is compatible with the parade field's use. The parade field is much like it was when it was first constructed and conveys the original design intentions of the area.

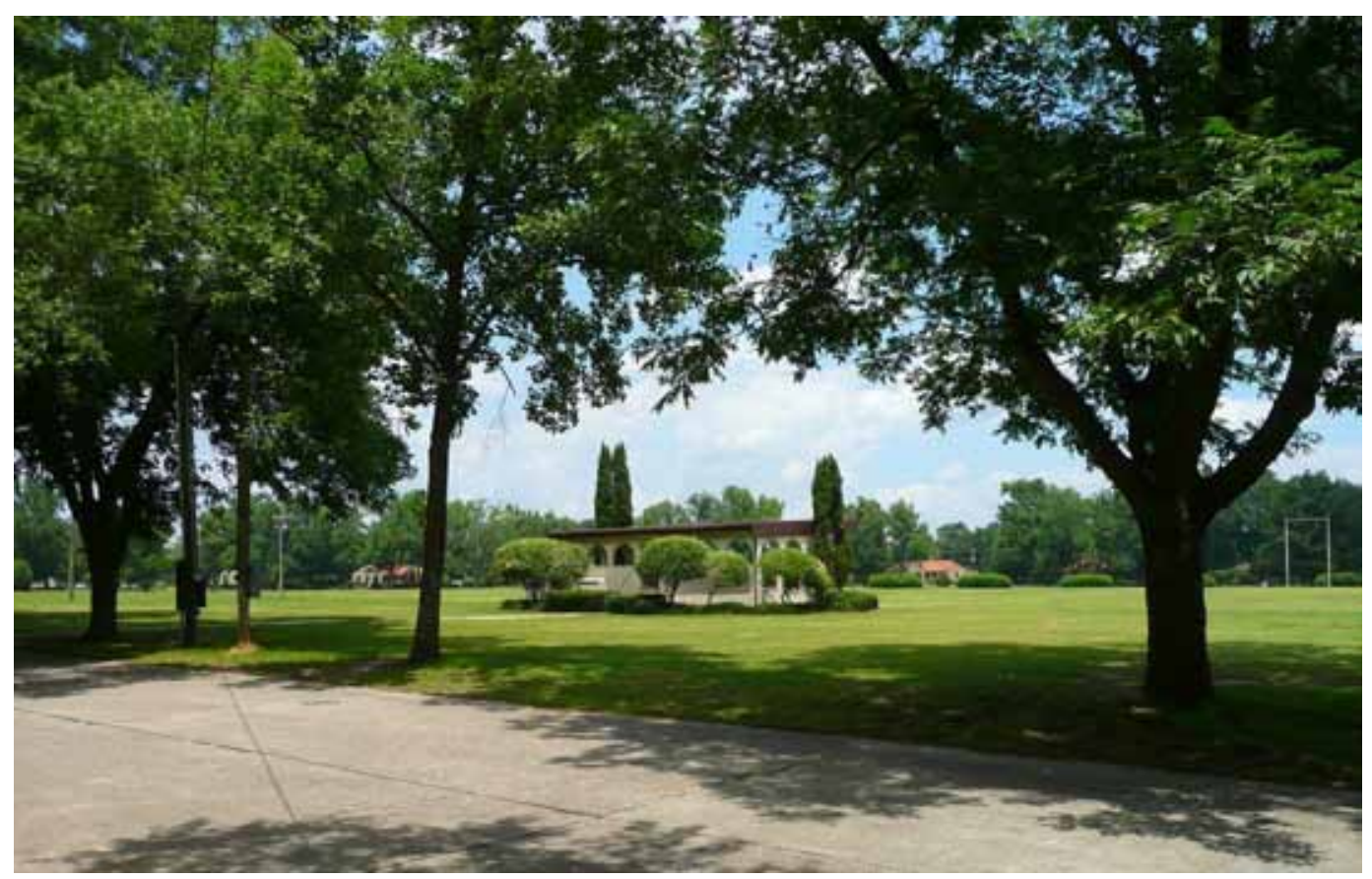

Figure 59. Parade field review stand looking northeast, 2009 (ERDC-CERL). 


\section{Design Recommendations}

- Maintain the parade field as an important ceremonial open space within the cantonment. Keep the open views across the parade field, especially toward the chapel.

- The vegetation in the flag pole area should be well groomed and should accentuate, but not overpower, the memorials (Figures 60-62).

- The trees surrounding the parade field should be maintained and replaced in-kind when needed.

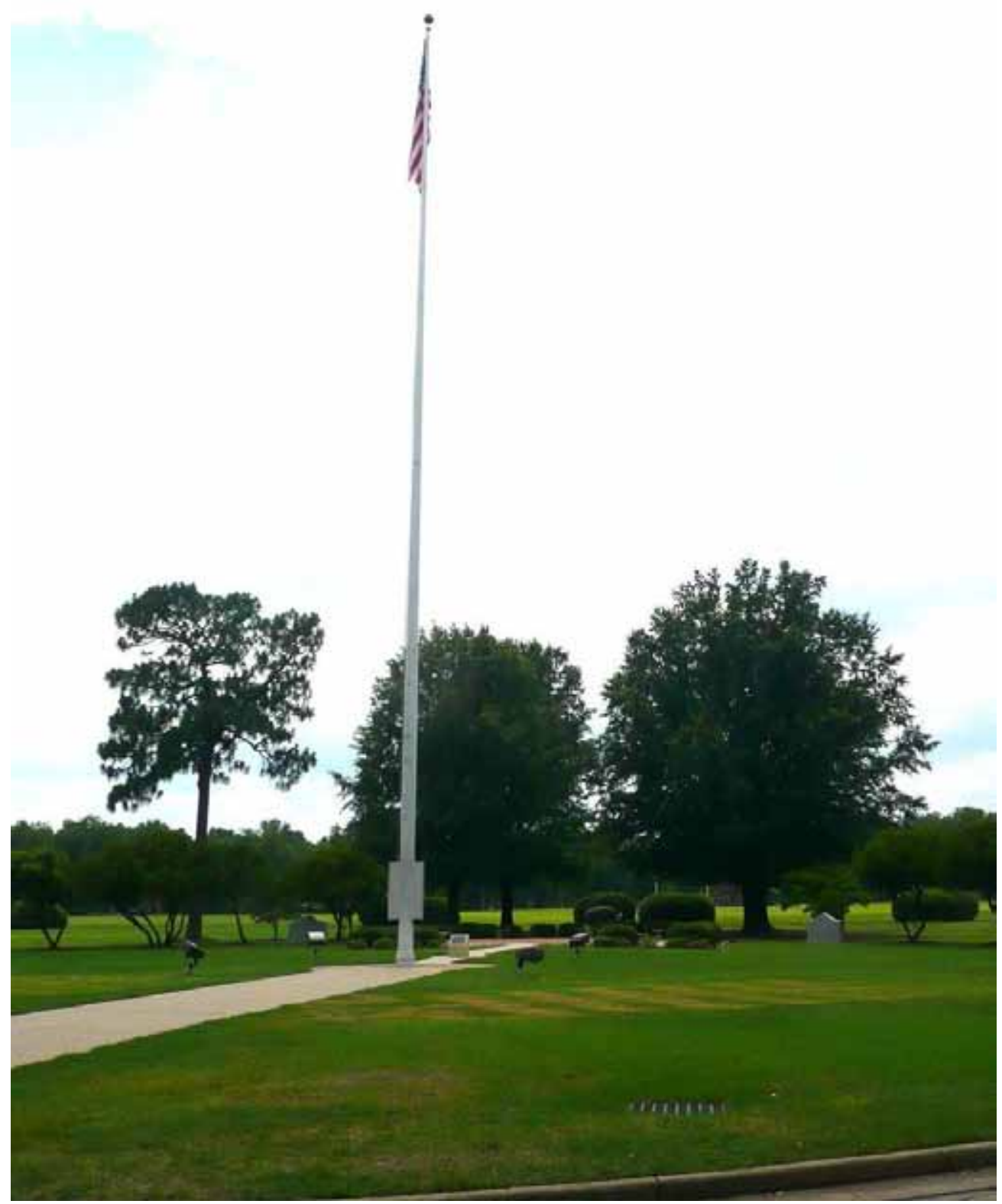

Figure 60. Flagpole area with parade field in the background, 2009 (ERDC-CERL). 


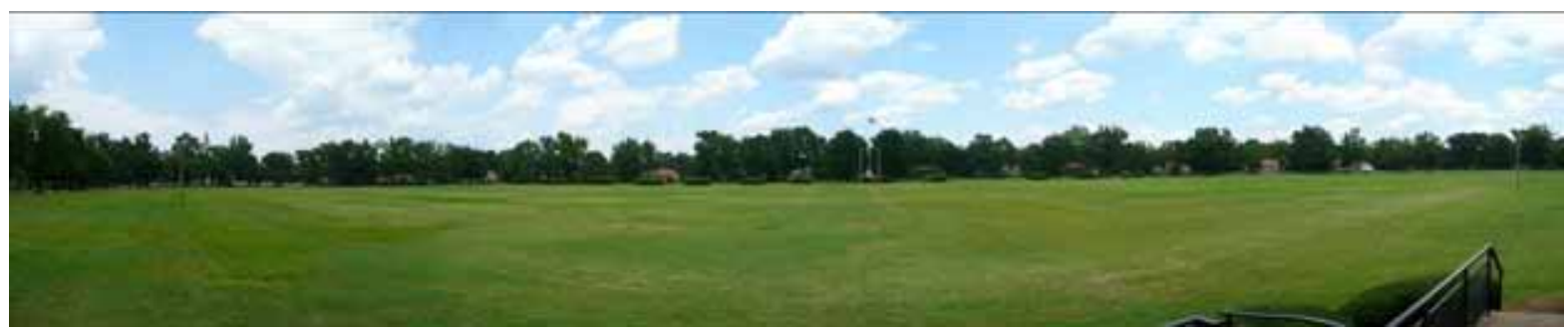

Figure 61. Parade field looking east toward the flagpole showing the perimeter framed in trees and the chapel on the left side, 2009 (ERDC-CERL).

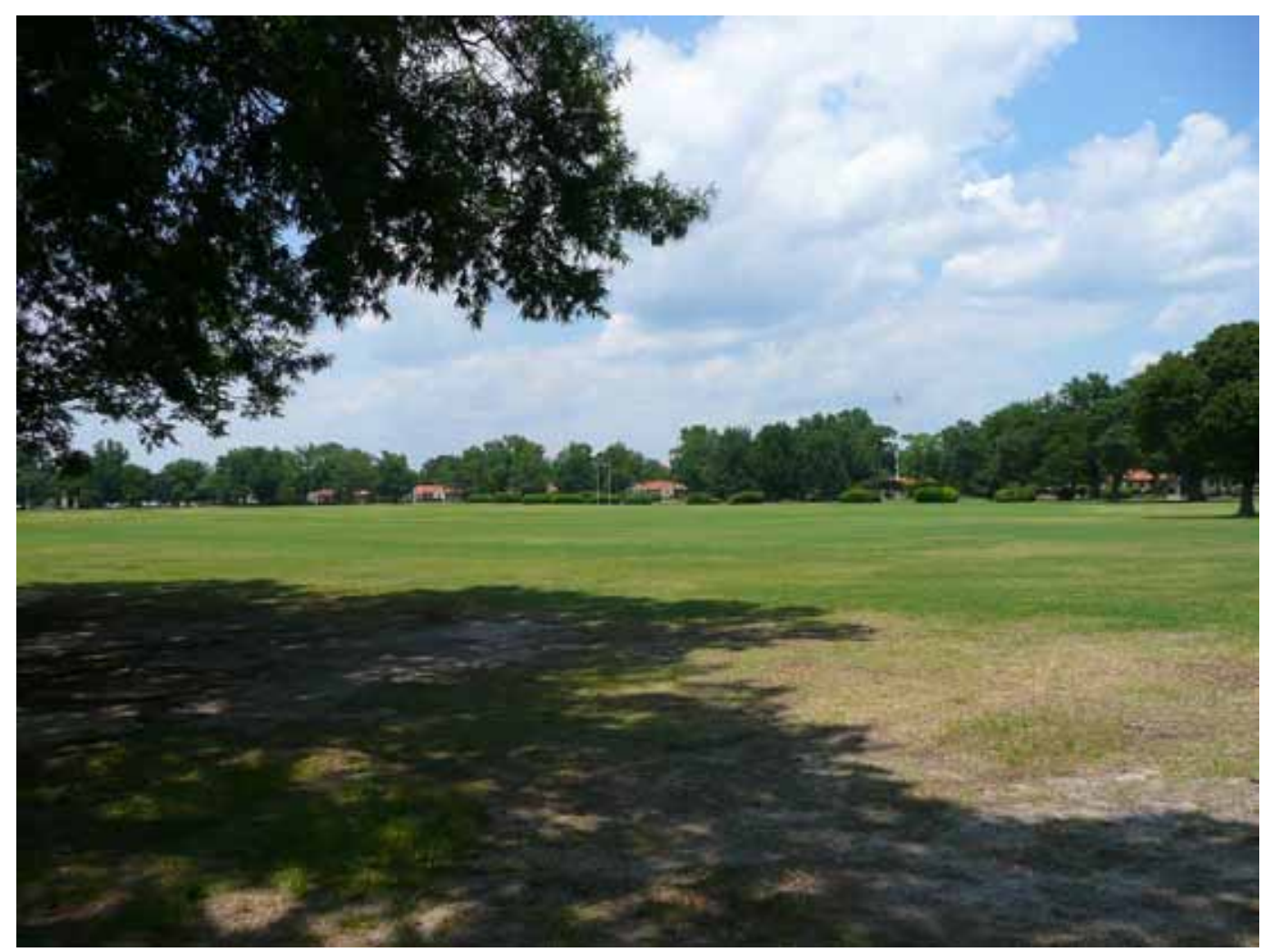

Figure 62. Parade field with the flagpole area on the right, 2009 (ERDC-CERL).

\section{Support Building Area}

In this report, the support buildings of the historic district are divided into two groups according to their architectural styles and their general locations. The buildings in the Georgian Revival style are the former headquarters, the old hospital, the former barracks, and the theater. The second group of buildings in the Spanish Eclectic style are the chapel, Nurses' quarters, Bachelor's Officers' Quarters, and the Officers' Club. The Georgian Revival buildings are mostly in the administrative core of the cantonment, while the Spanish Eclectic styled support buildings are near the Normandy Heights neighborhood. 
The landscapes around the support buildings include several scales of implementation, such as the buildings' context, its location in the district, and the vegetation and plantings around the specific building. First, these landscapes should be viewed in the context of how the support buildings are arranged within their physical contexts. Secondly, the hierarchy of the buildings should be considered; for example the old headquarters and hospital buildings were located in a prominent area because their functions were integral to operations. Thirdly, the vegetation patterns should be considered as a unifying feature of the buildings within the district, not as mere ornament. Understanding these elements of the landscape will preserve the continuity of the historic district.

\section{Historic Characteristics}

- In the 1920s, the administrative core of the post was along Macomb Street (Figure 63). The center of this core was the post headquarters (Figure 64) and hospital (Figure 65), which were prominently located at the intersection of Macomb and Armistead Streets. These were built in the Georgian Revival architectural style.

- Five barracks for enlisted men line Macomb Street (Figure 66); there are also two barracks on Armistead Street and one on Hamilton Street.

- The theater (Figure 67) is located on Macomb Street near Reilly Road and was in the civic center of the cantonment.

- The Spanish Eclectic-style chapel is located at the north end of the parade field and is a focal point for the administrative core and the Normandy Heights neighborhood.

- The Bachelor Officers' Quarters (BOQ) was located at the corner of Totten and Armistead Streets and is across the street from the Officers' Club (Figure 68); both buildings match the Spanish Eclectic architectural style of Normandy Heights. 


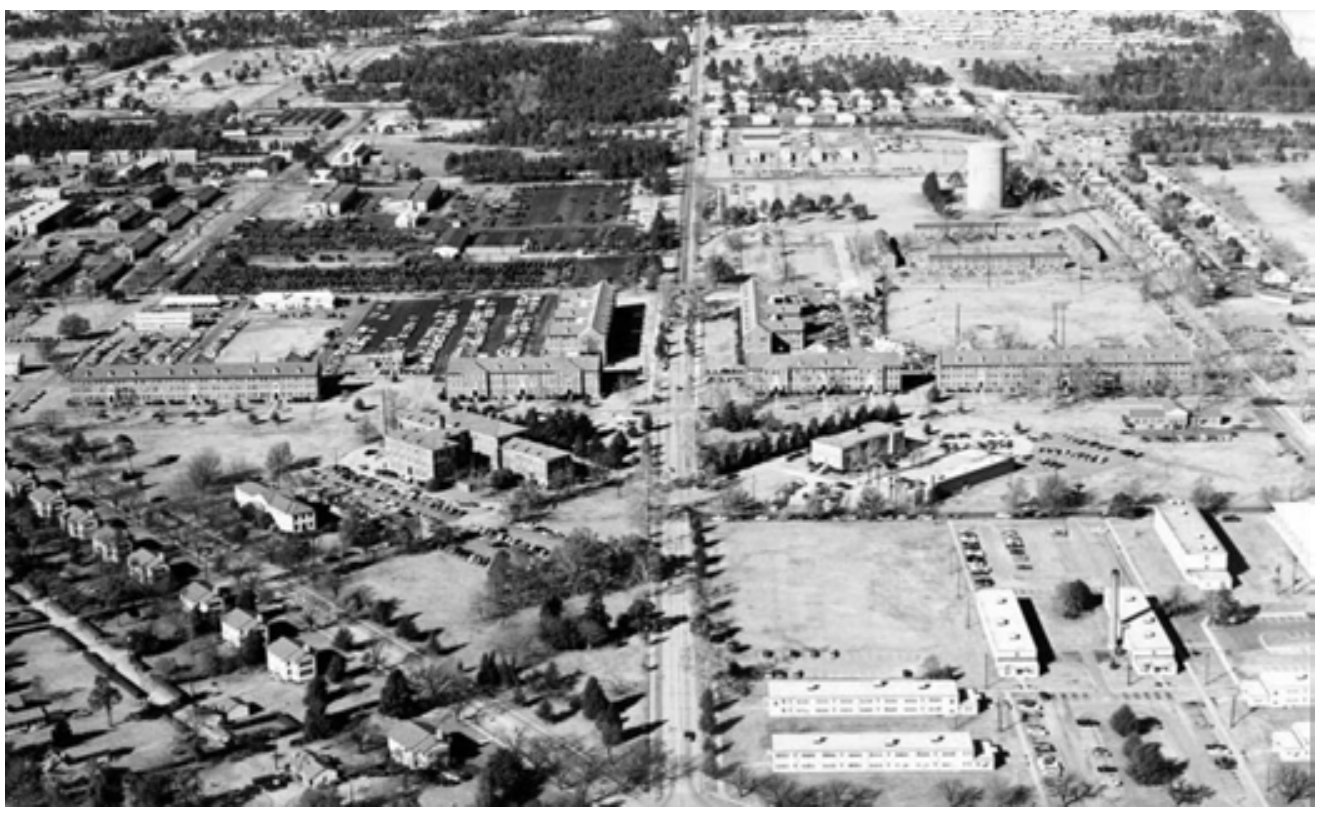

Figure 63. Aerial view showing the administrative core at the intersection of Macomb and Armistead Streets, 1960s (Fort Bragg Cultural Resources).

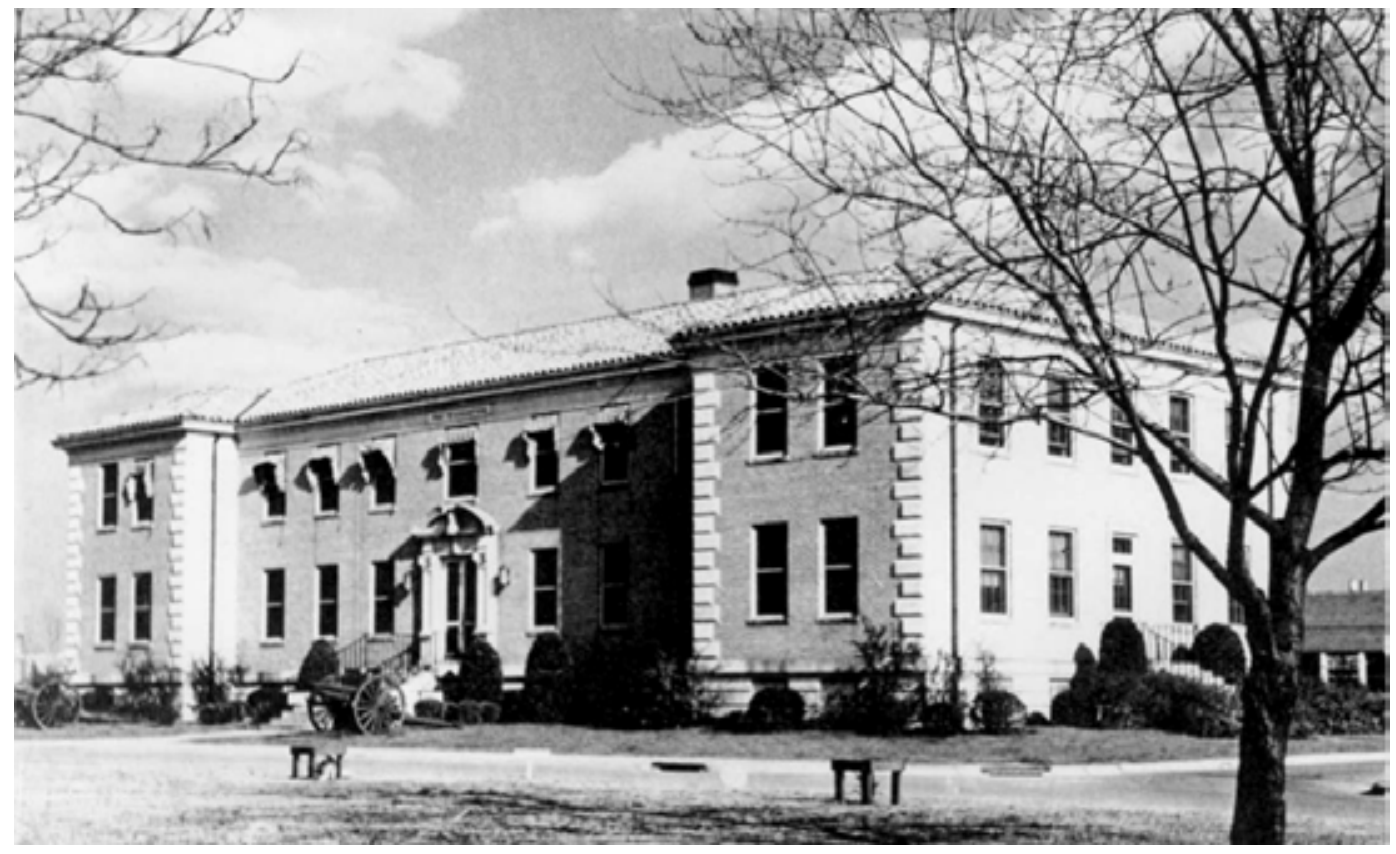

Figure 64. Post Headquarters, 1941 (Fort Bragg Cultural Resources). 


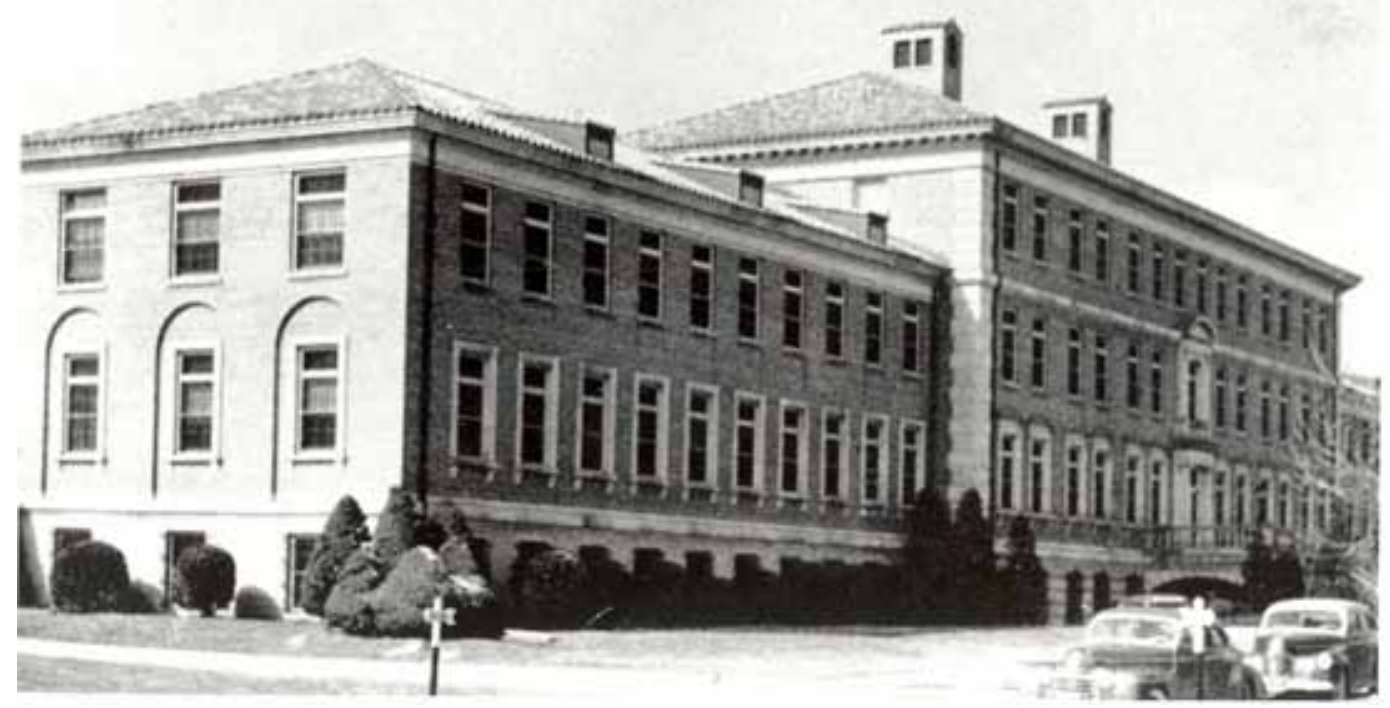

Figure 65. Station Hospital, 1941 (Fort Bragg Cultural Resources).

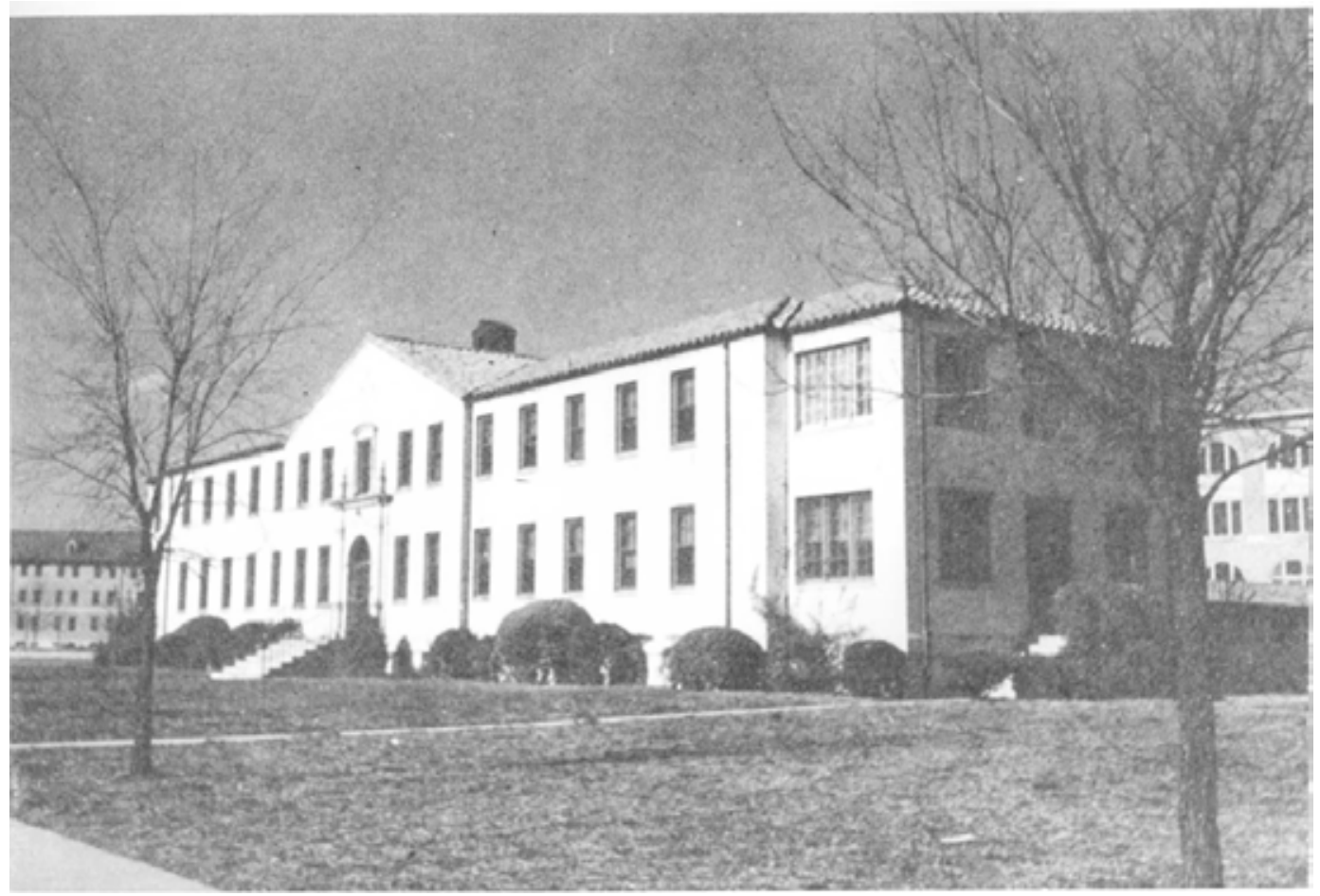

Figure 66. Nurses' Quarters, 1941 (Fort Bragg Cultural Resources). 


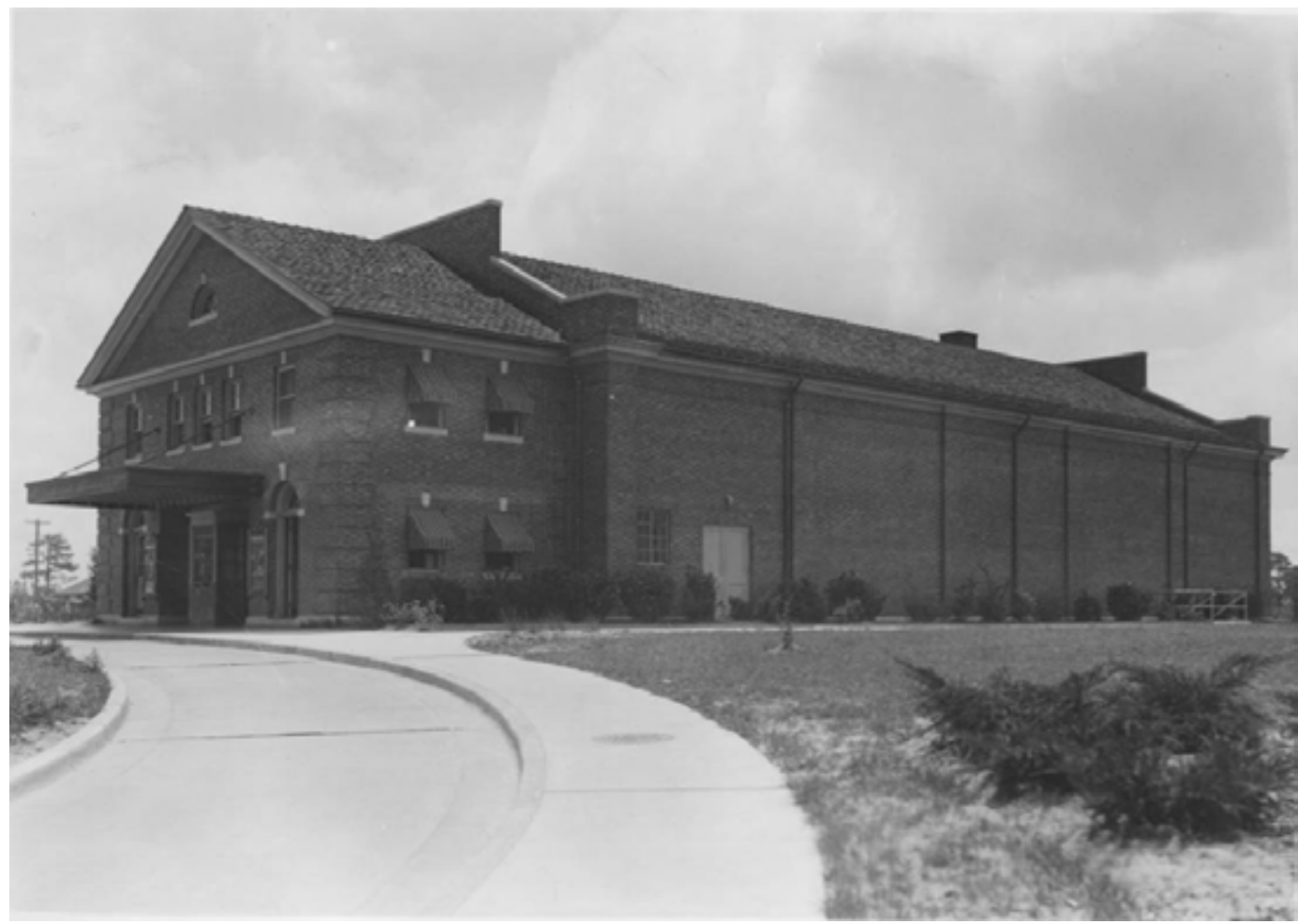

Figure 67. Theater, 1940s (NARARG-77-391 Boxes 49-52).

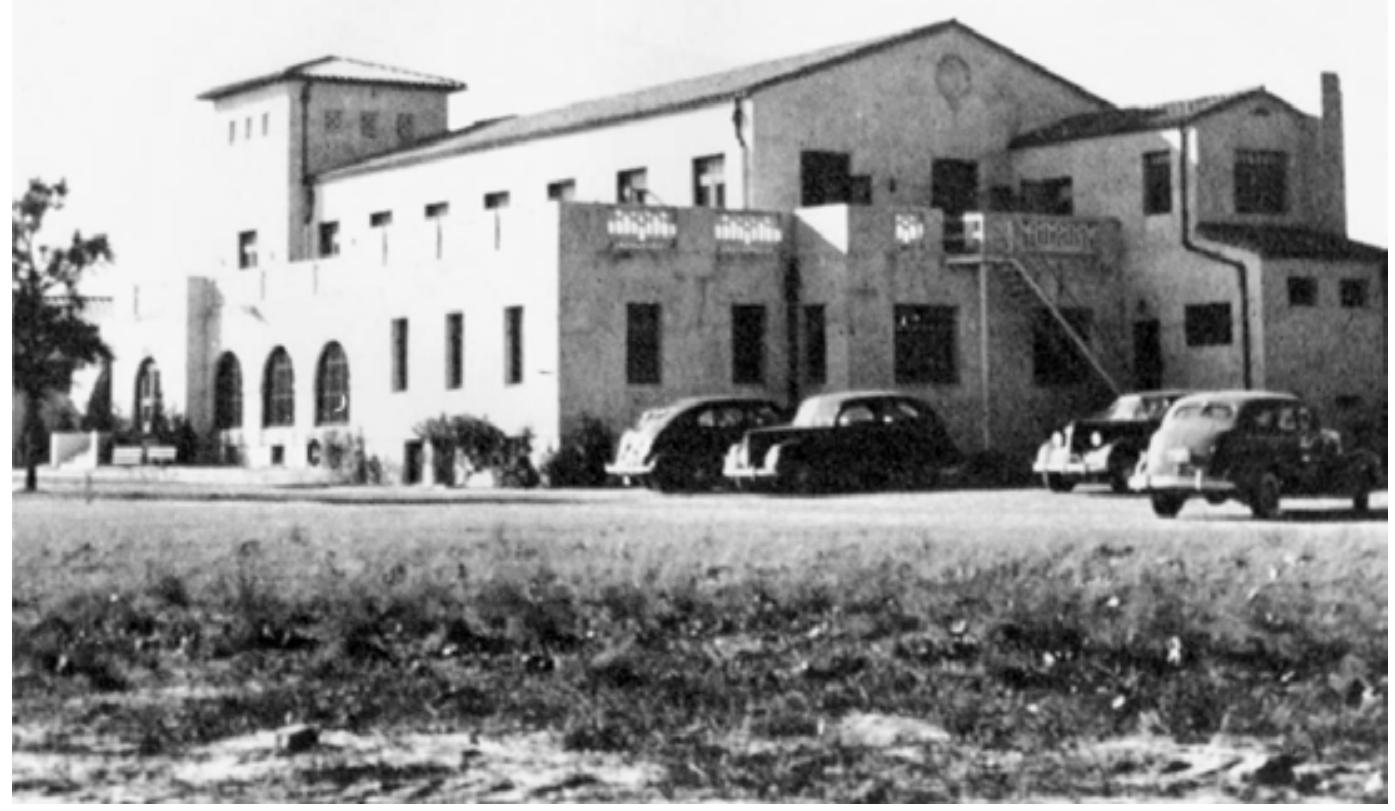

Figure 68. Officers' Qub, 1941 (Fort Bragg Cultural Resources). 


\section{Existing Conditions}

The physical context of the support building area has not changed significantly since the original layout of the cantonment. While temporary buildings have been built in the OPHD, the permanent structures from the 1930s have retained their original massing and scale. However, around some of these buildings parking lots have been added, which interrupts the park-like context of the buildings.

Several of the support buildings have been repurposed; namely the buildings that comprised the historic administrative core. The former headquarters and barracks are now used for general administrative purposes. The former hospital building (Figure 69) is currently being used as the headquarters for the XVIII Airborne Corps and Fort Bragg. New fencing has been added around the building to comply with the security with the Anti-Terrorist/ Force Protection (AT/ FP) standards. The former BOQ is now a guest house for visitors. Reappropriating the functions of these buildings negates the hierarchy of use established in the original context of the cantonment. For example, while still important, the former Headquarters and hospital buildings no longer provide same integral services for the installation; however, they are still prominently located.

The vegetation around the support buildings is quite varied in the quantity of plantings and the level of maintenance the landscaping receives. The chapel (Figure 70) and Officers' Club (Figure 71) have extensive landscaping that is well taken care of, but the vegetation around the theater (Figure 72) and former barracks is sparsely planted. However, there is a fairly consistent pattern of landscaping around the support buildings (e.g., Figure 73). The planting pattern consists of medium to large evergreen shrubs that frame the entrances and corners of buildings with smaller shrubs along the foundations. Ornamental trees are used as accents throughout the evergreens. 


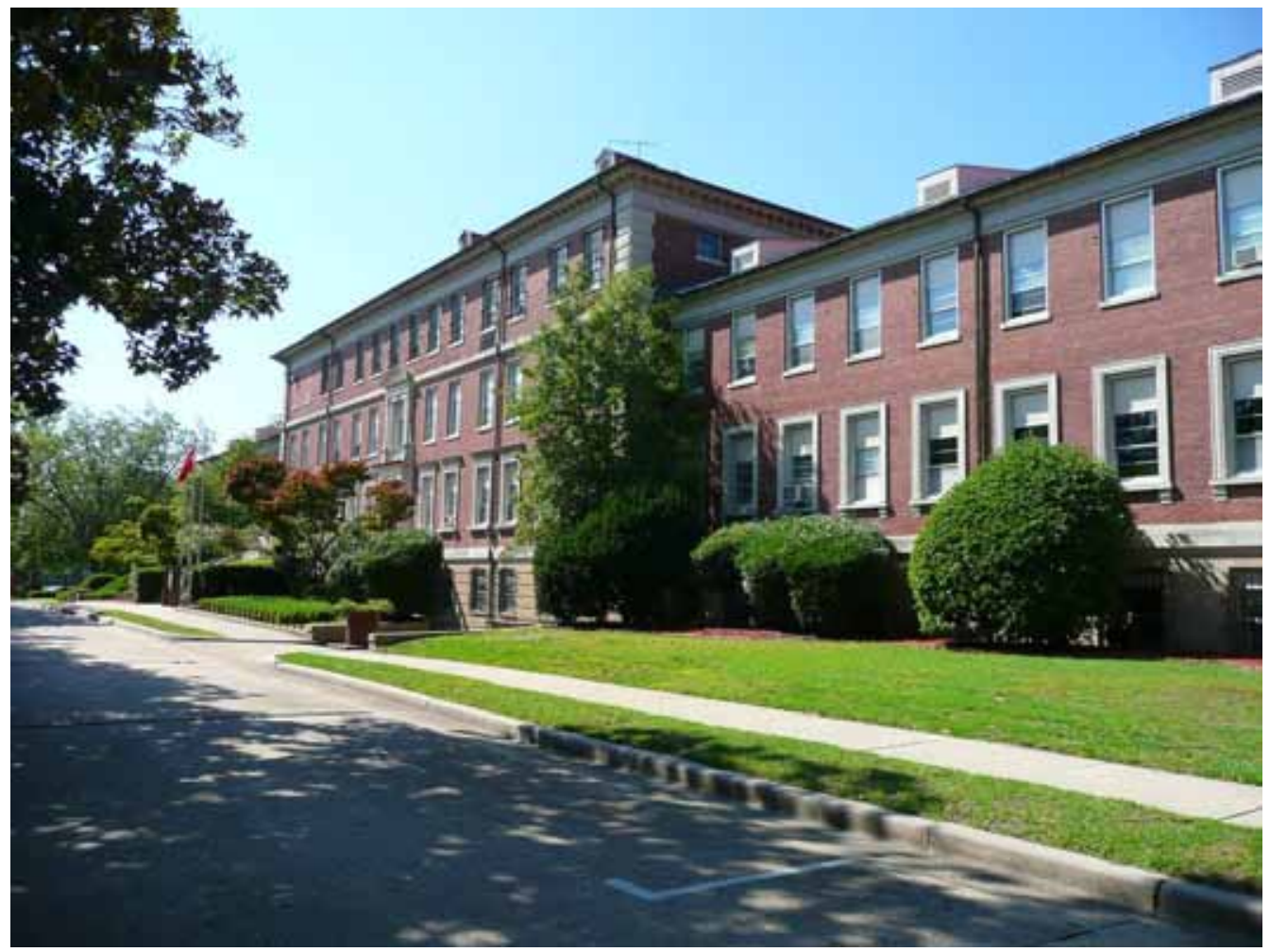

Figure 69. The old hospital, now the headquarters for the 82nd Airbome Division, 2009 (ERDC-CERL).

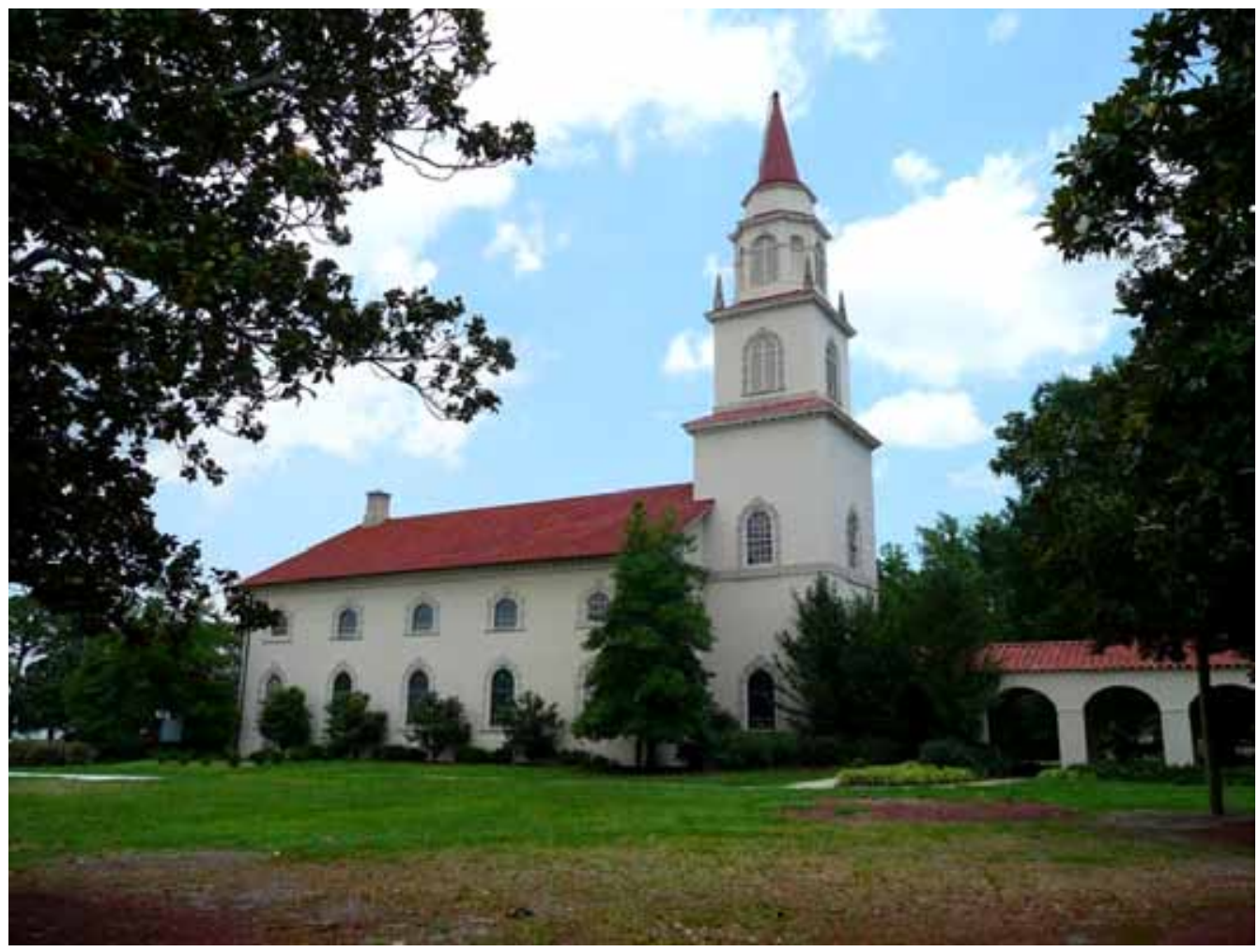

Figure 70. The chapel landscape, 2009 (ERDC-CERL). 


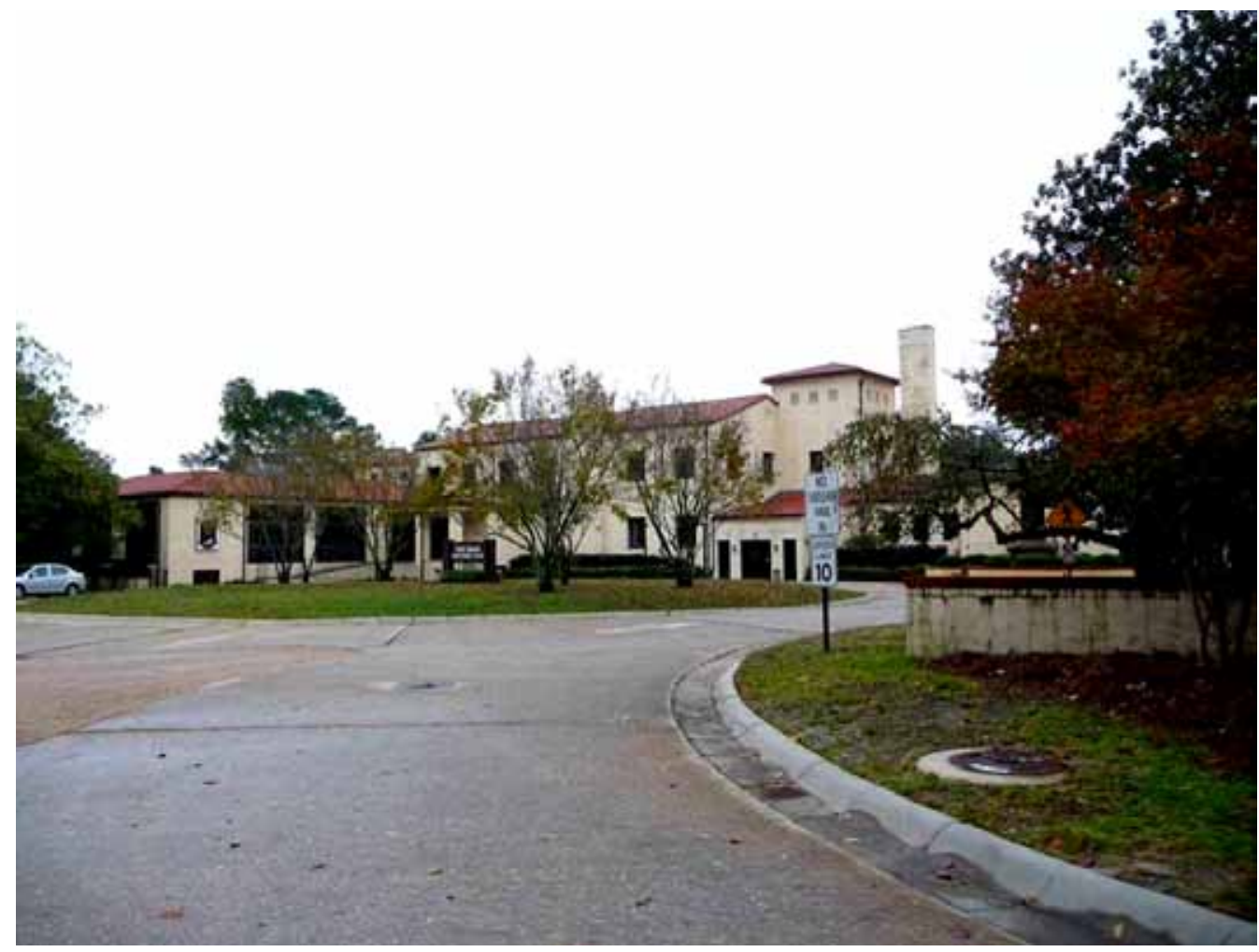

Figure 71. Former Officers' Club, 2007 (ERDC-CERL).

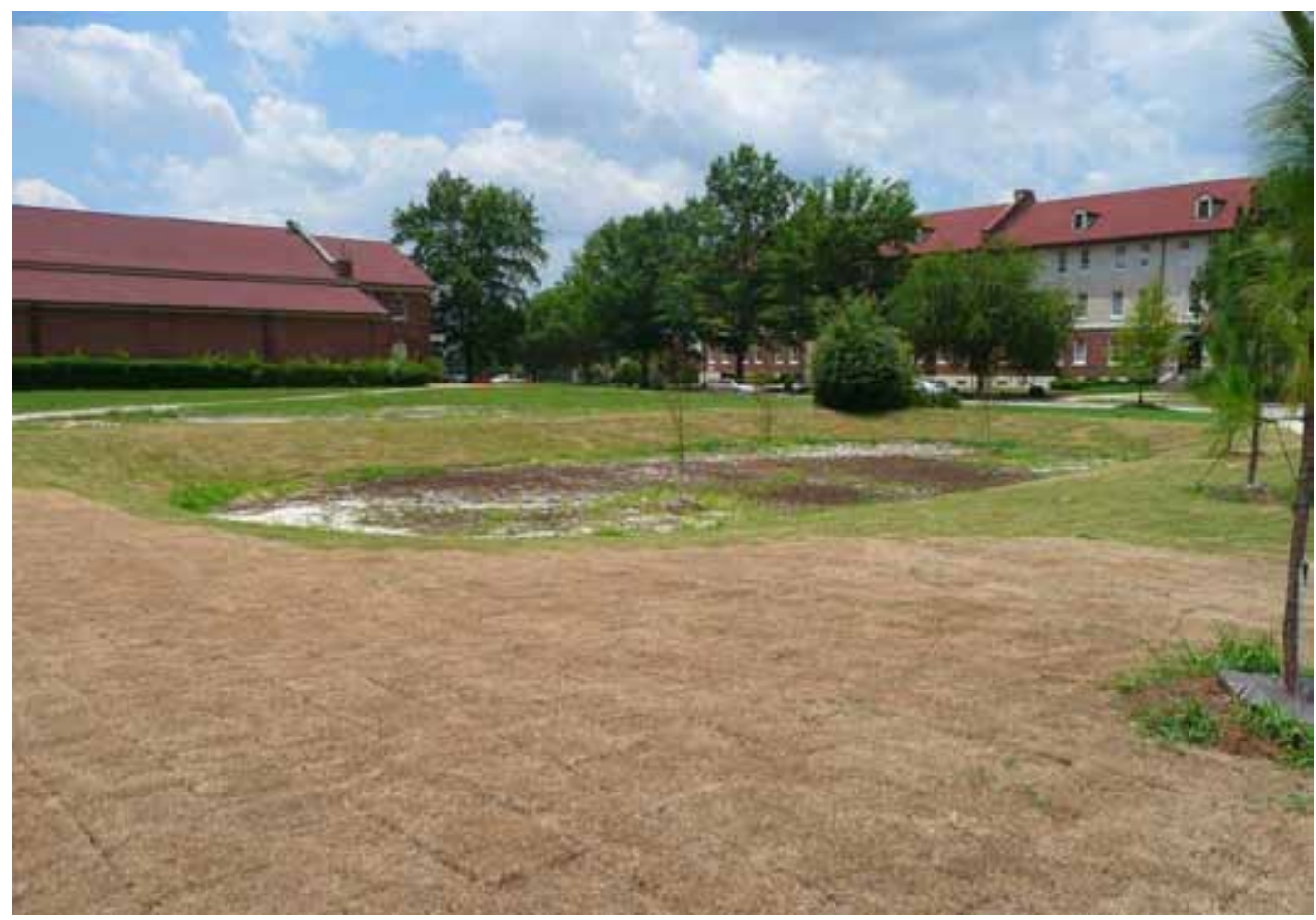

Figure 72. Theater on the left, converted barracks on the right, 2009 (ERDC-CERL). 


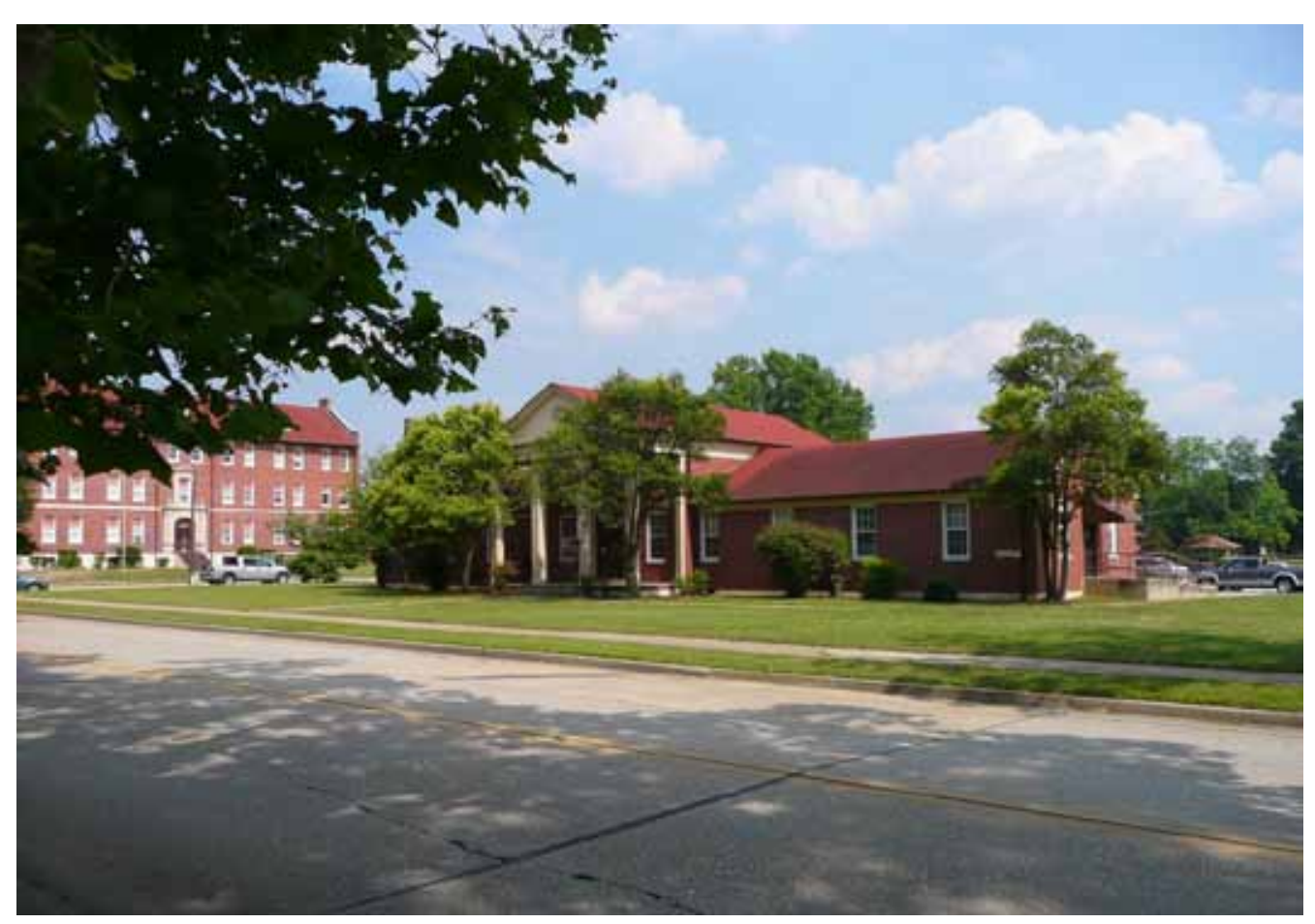

Figure 73. Red Cross Building landscape, 2009 (ERDC-CERL).

\section{Design Recommendations}

- Limit the growth of parking lots around the support buildings.

- Planting patterns should extend around the buildings and incorporate any additional entrances and views to the buildings (Appendix B).

- Create a consistent palette of plant material, mulch, and edging products throughout the historic district (Appendix C).

- Historically evergreens were most often used in foundation plantings at Fort Bragg; however, it is ideal to have a mix of deciduous and evergreen plants. Where building occupancy requires AT/ FP, consider planting a mix of flowering trees (with visible branching structure) and an evergreen ground cover bed (not to exceed a height of $12 \mathrm{in}$.). In addition, highly columnar evergreens can be used to make entrances and create form (provided they meet the AT/ FP Standards). The use of flowering plants near building entrances can give needed interest. When possible select native plants that correspond to the habit, texture, and showiness of the originally-specified plants (Appendix C).

- Using mature spread as an indicator, plant trees and shrubs several feet from the building to prevent damage to the foundation and façade.

- Discipline and order are cultural traditions of the military, therefore, select plants and cultivars with these traits and eliminate the need for trimming and additional maintenance. 
- Grouping plants is more effective at creating visual and spatial interest than a sporadically planted row. Historically, groupings of plants were used at the corners of buildings, adjacent to doorways, and to soften large areas of buildings that lacked architectural features (Appendix B).

- Modern landscaping techniques should comply with the historic aesthetics of the OPHD. For example, hedgerows should be straight and uniform (cf. Figure 74); the use of swales should be minimal and should conform to the original design of the district; planting beds should be uniform. Landscaping pavers are not an appropriate border material (cf. Figure 75).

- The buildings that comprise the administrative core should relate to one another. The fence added around the former hospital should not isolate the building. Continuity should be preserved between the administrative buildings, the streets, and the rest of the installation.

- Changes to the non-contributing areas to the northeast of the barracks and south of the former headquarters should consider the visual and spatial relationships of the administrative core with the rest of the OPHD.

Figures 76- 85 show the plan and elevation views of proposed plantings for the former headquarters, old hospital, theater, chapel, and barracks, respectively. 


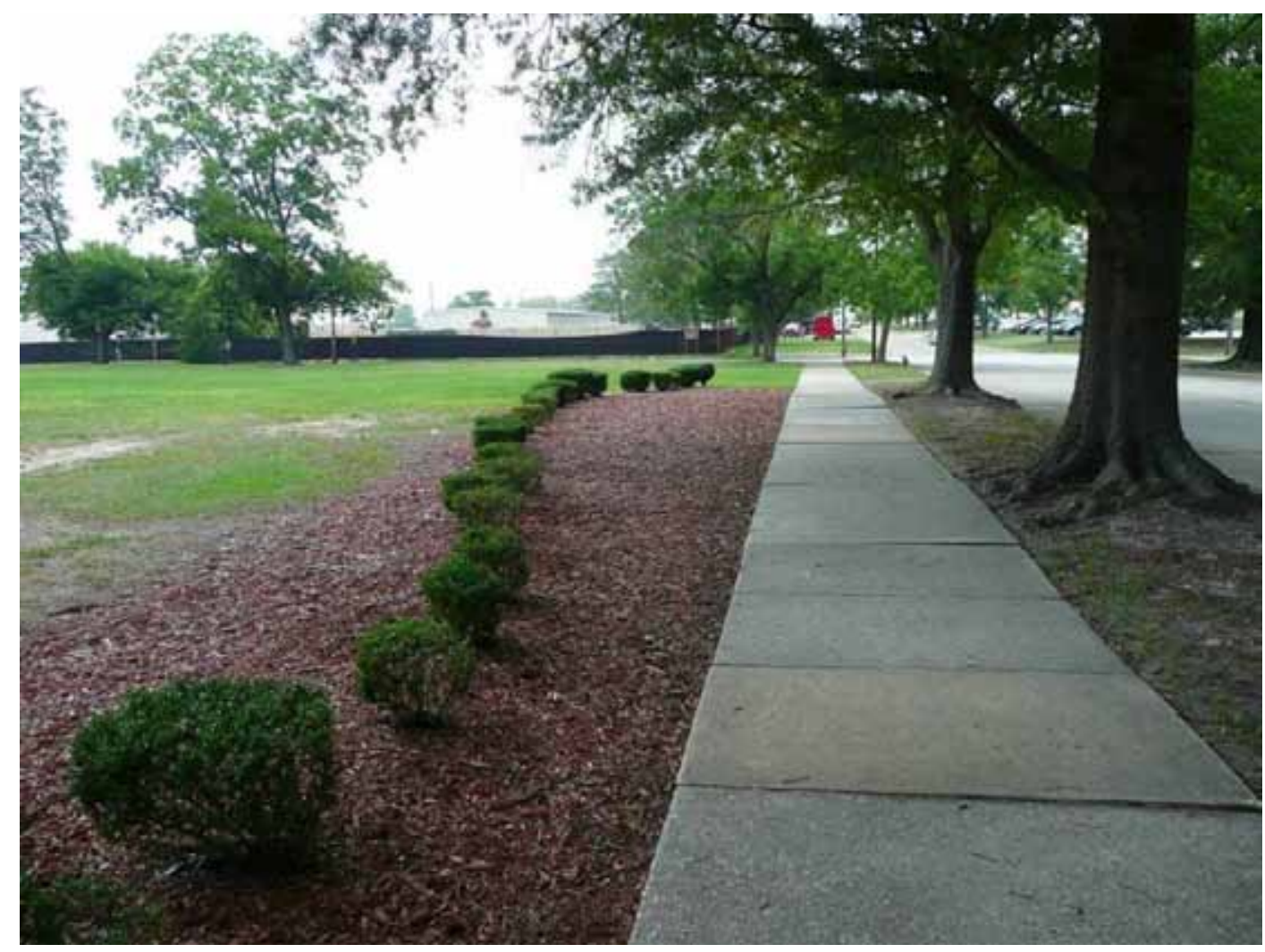

Figure 74. Imegularly planted hedgerow, 2009 (ERDC-CERL).

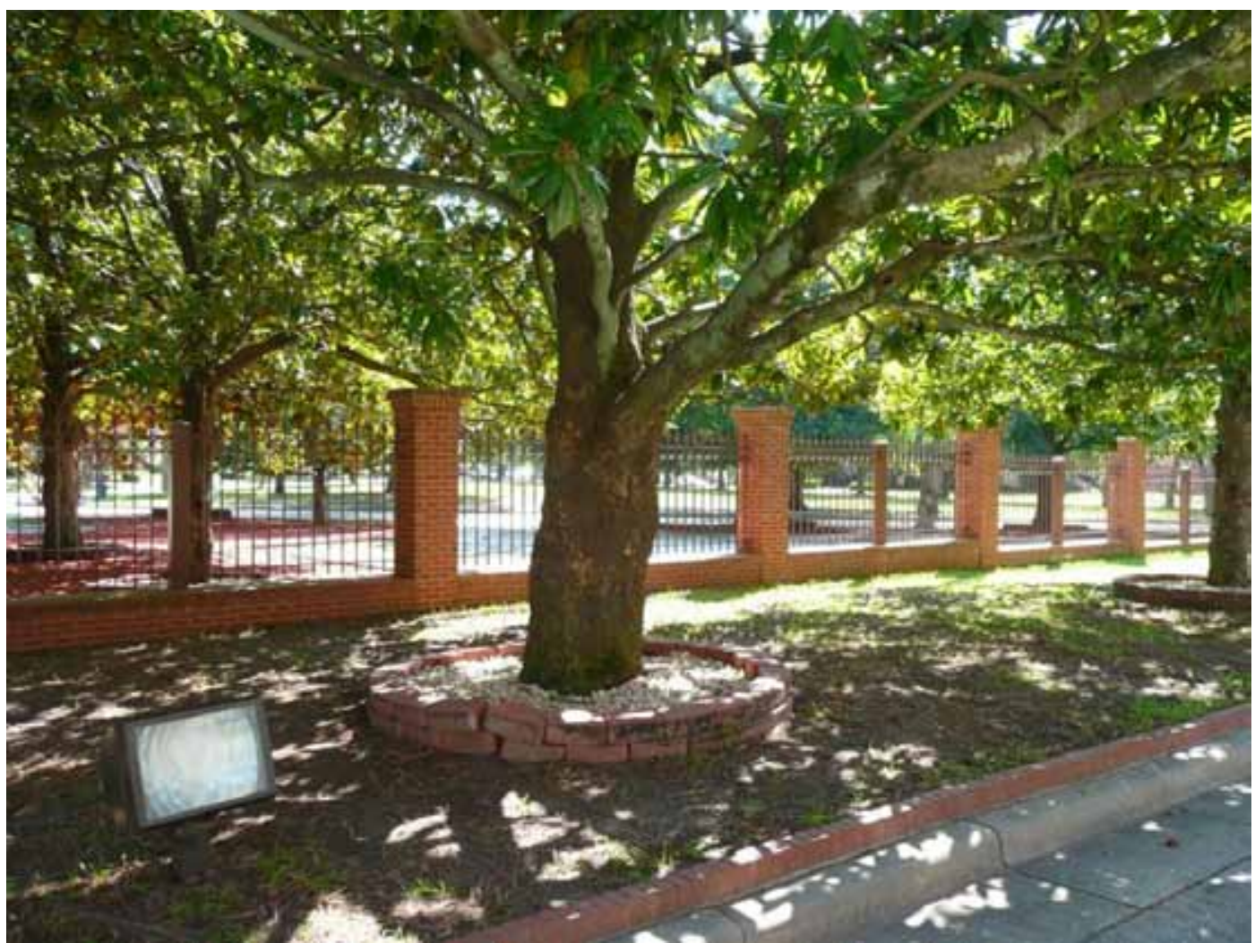

Figure 75. Modem pavers used as border, 2009 (ERDC-CERL). 


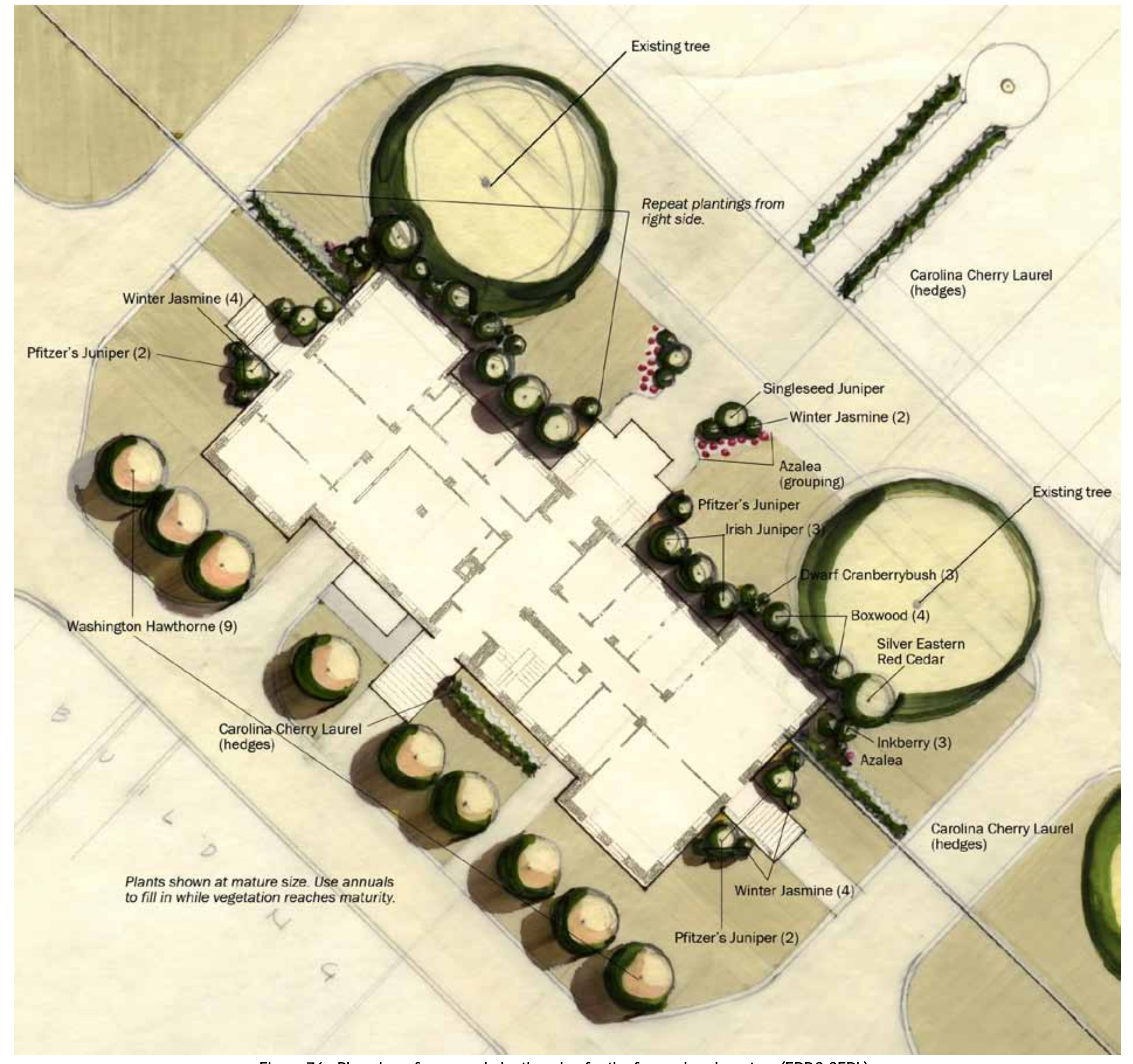

Figure 76. Plan view of proposed planting plan for the former headquarters (ERDC-CERL). 


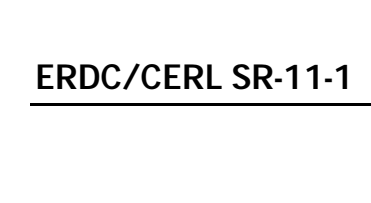




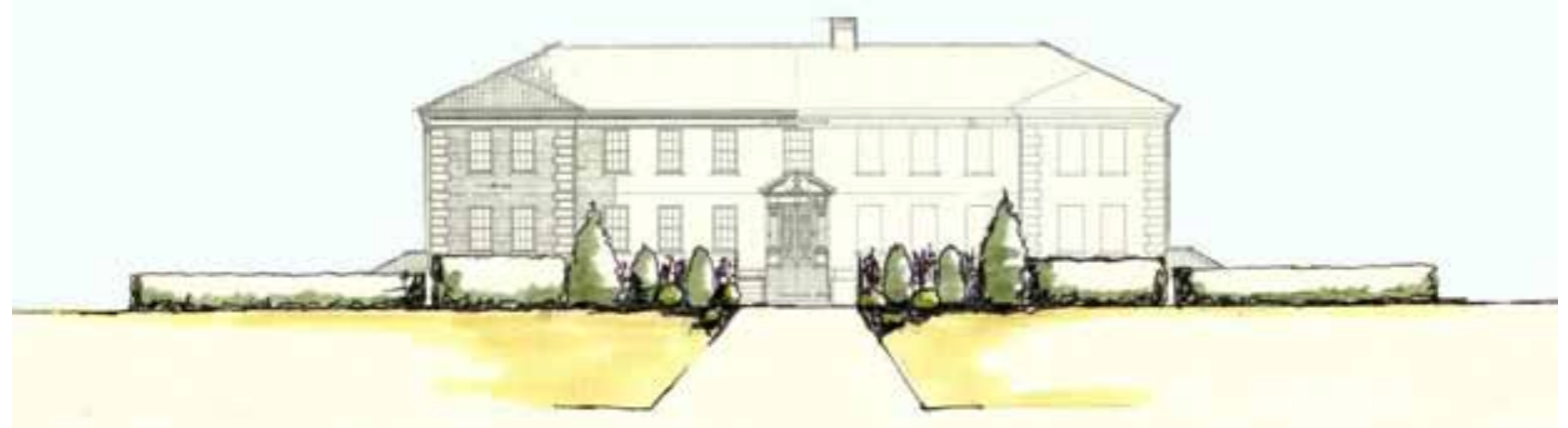

Figure 77. Elevation view of proposed planting for the former headquarters (ERDC-CERL). 


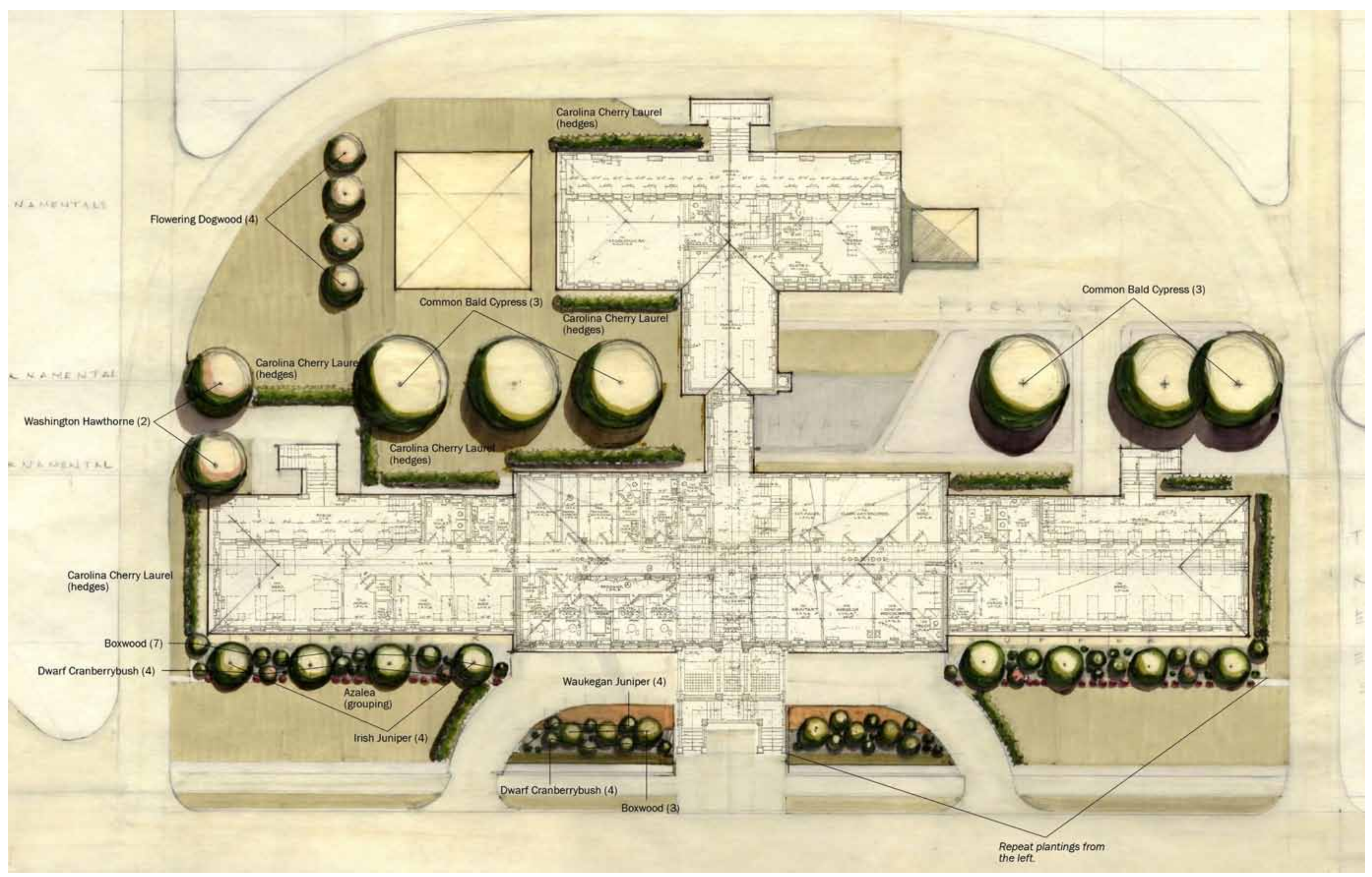

Figure 78. Plan view of proposed plantings for the old hospital (ERDC-CERL). 



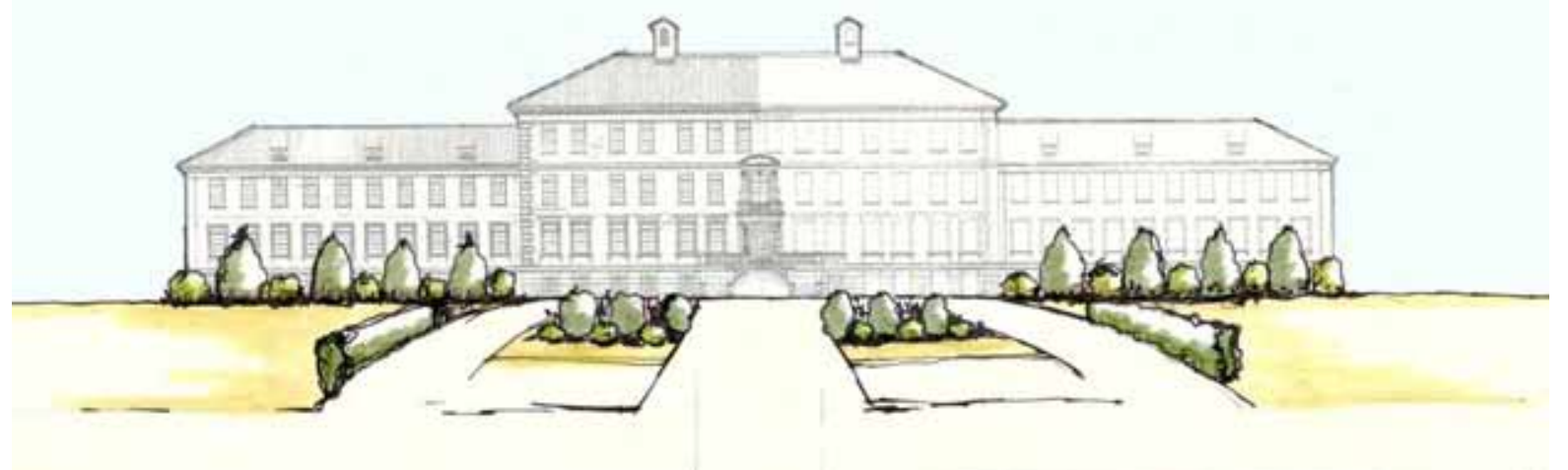

Figure 79. Elevation view of the planting plan for the old hospital (ERDC-CERL). 


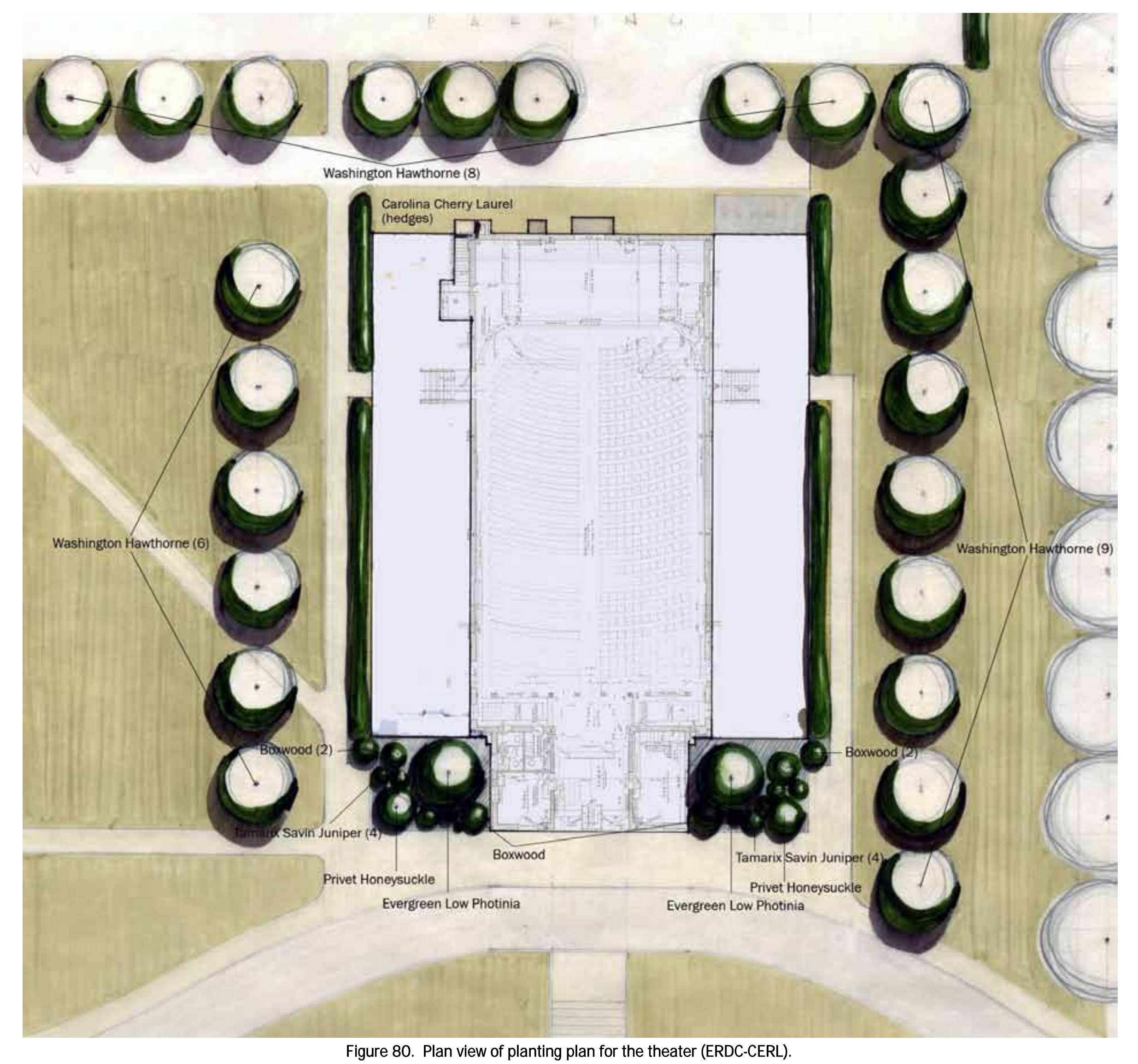

Figure 80. Plan view of planting plan for the theater (ERDC-CERL). 


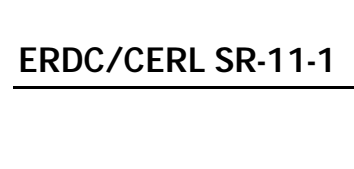




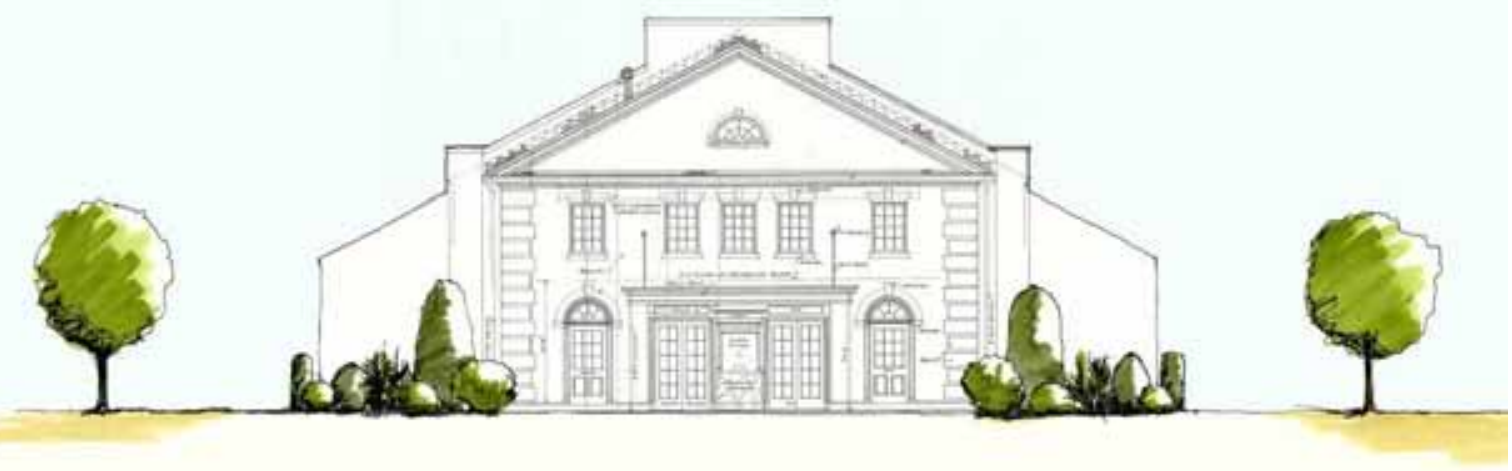

Figure 81. Elevation view of planting for the theater ERDC-CERL). 


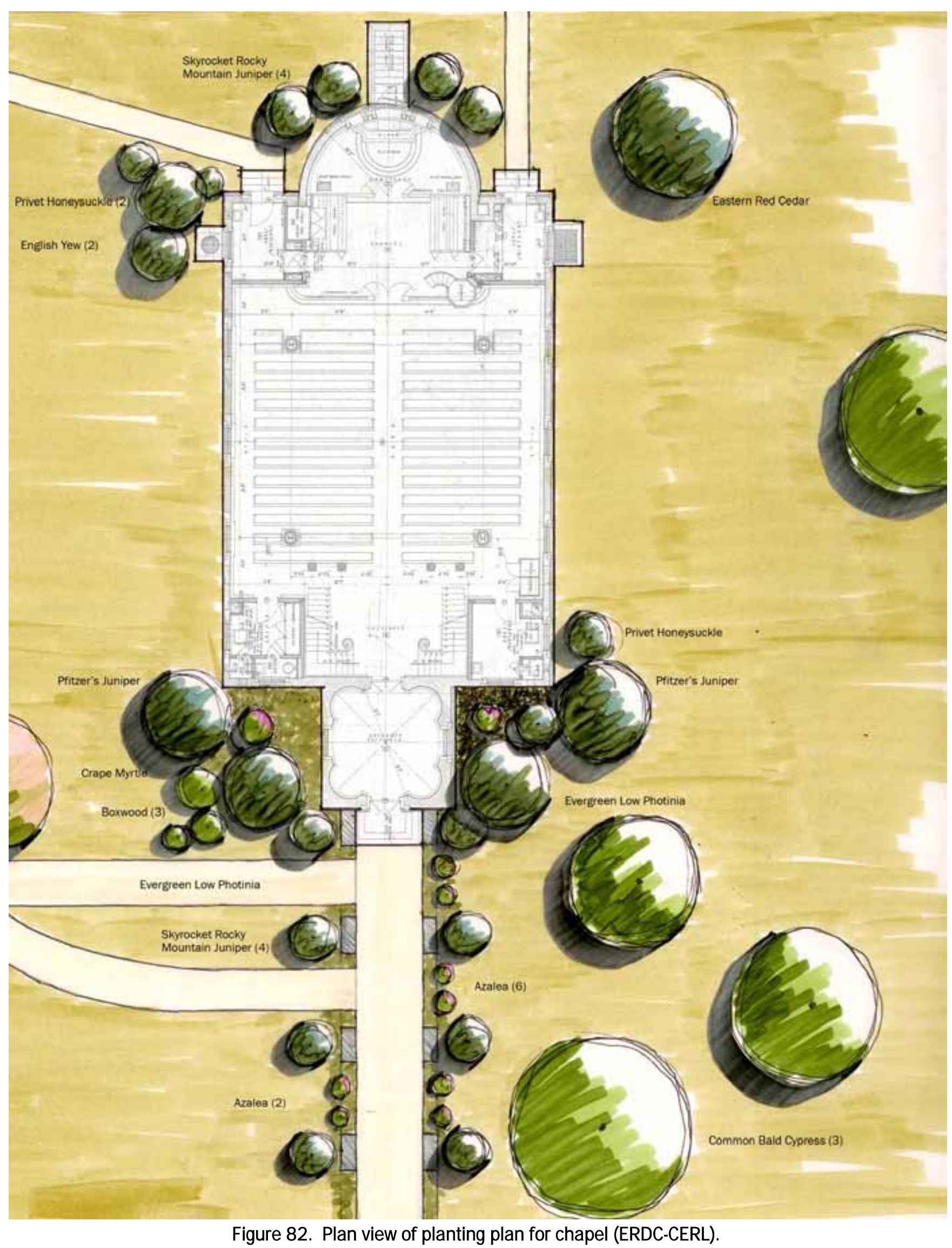




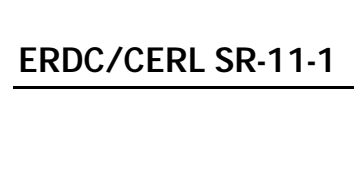




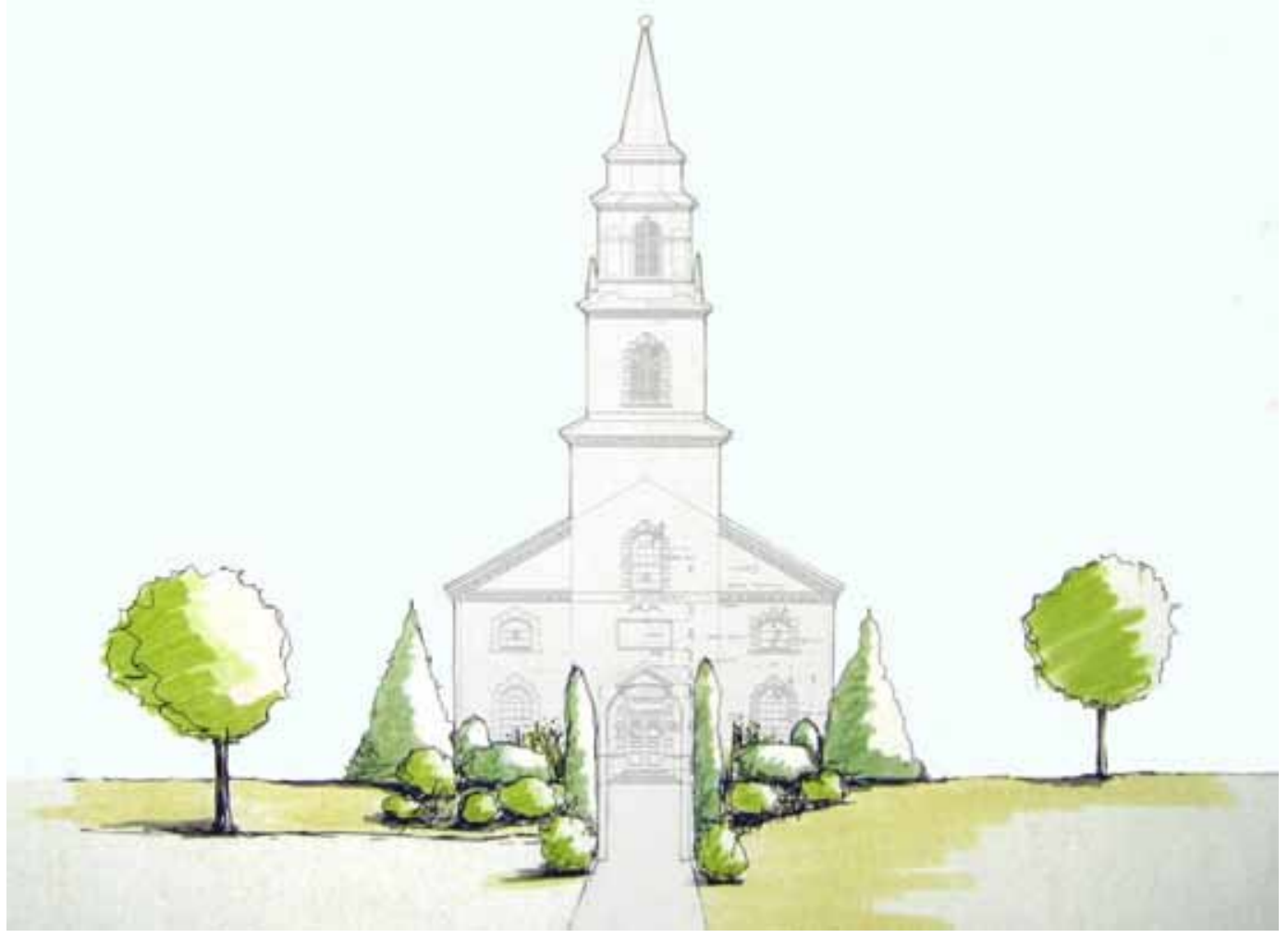

Figure 83. Elevation view of plantings for the chapel (ERDC-CERL). 


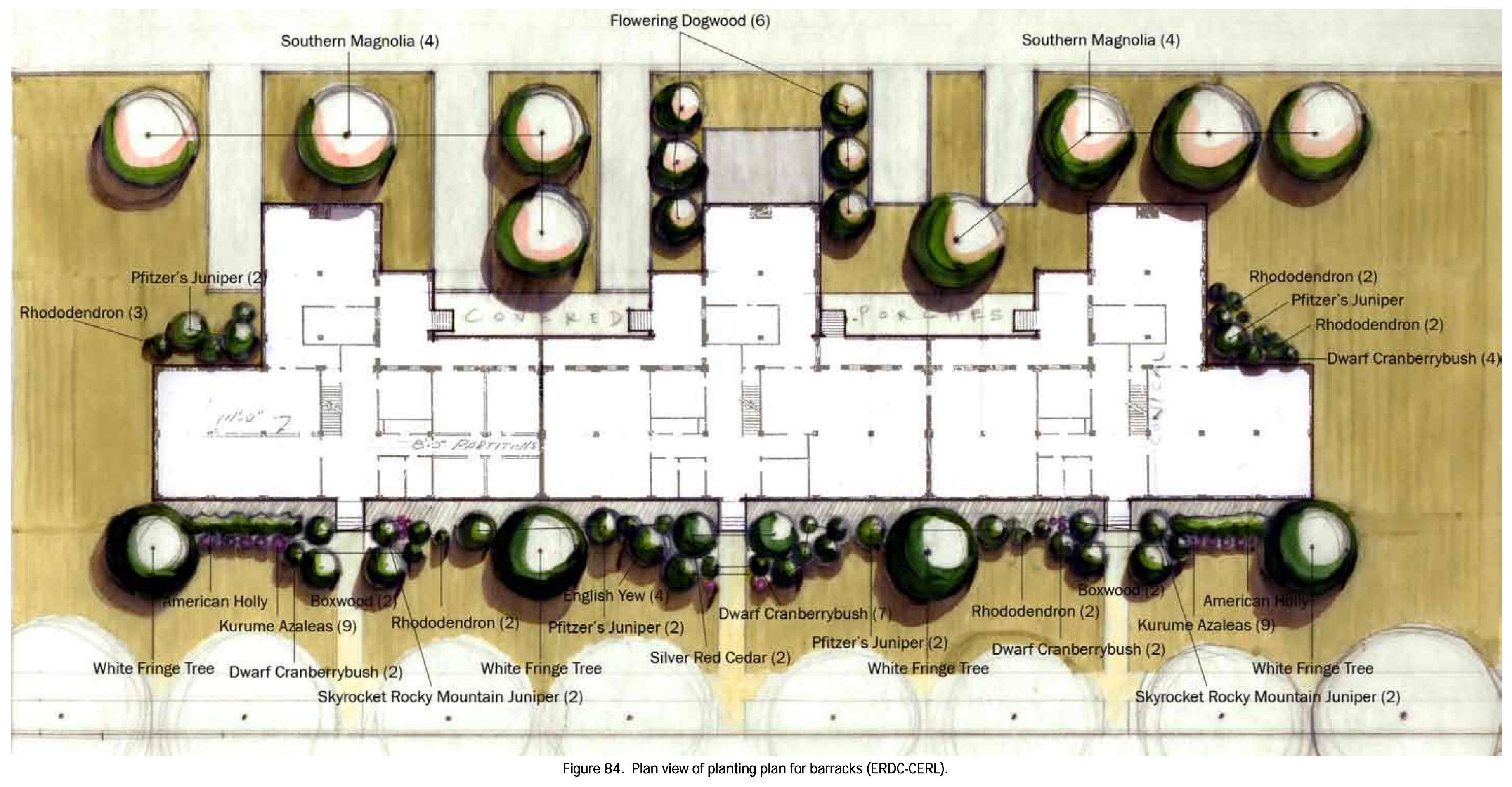




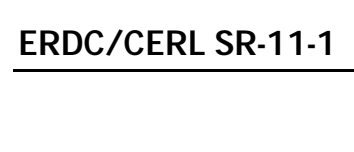




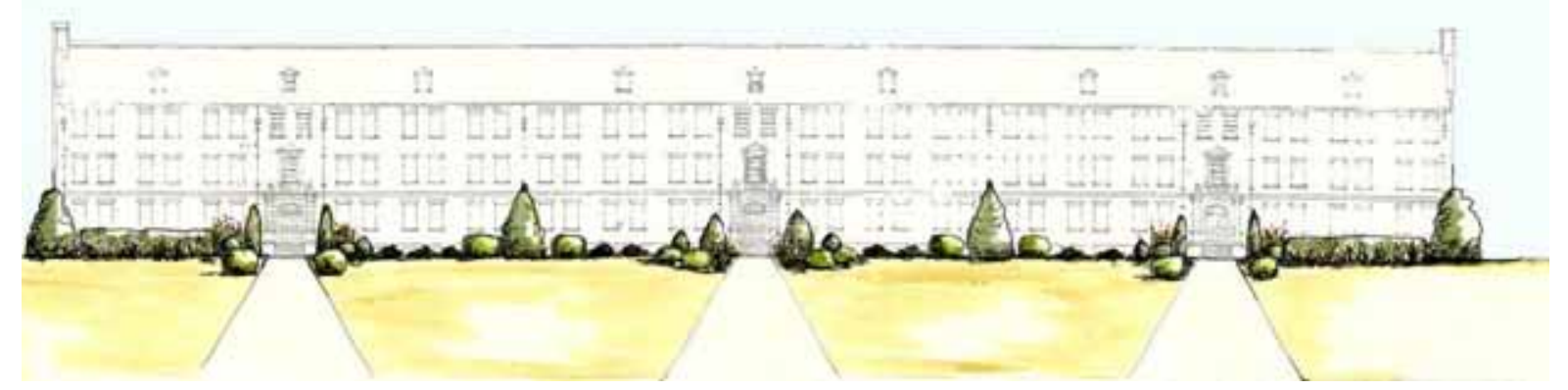

Figure 85. Elevation view of plantings for barracks (ERDC-CERL).

Mule Barn Area

Historic Characteristics

- Constructed in 1935, the mule barn area (Figure 86) was comprised of barns, stables, gun artillery sheds, and stable guard quarters. Because Fort Bragg was a field artillery training center, horses and mules were kept to transport field artillery equipment.

- The layout of the barns was on a rectilinear grid extending north from Woodruff Street. In the areas around the barns were corrals for the animals; these areas had scattered and minimal vegetation.

- The barns were converted into a motor pool and maintenance area when the Army mobilized for WWII (Figures 87 and 88). The areas around the guard houses were moderately landscaped (Figure 89). 


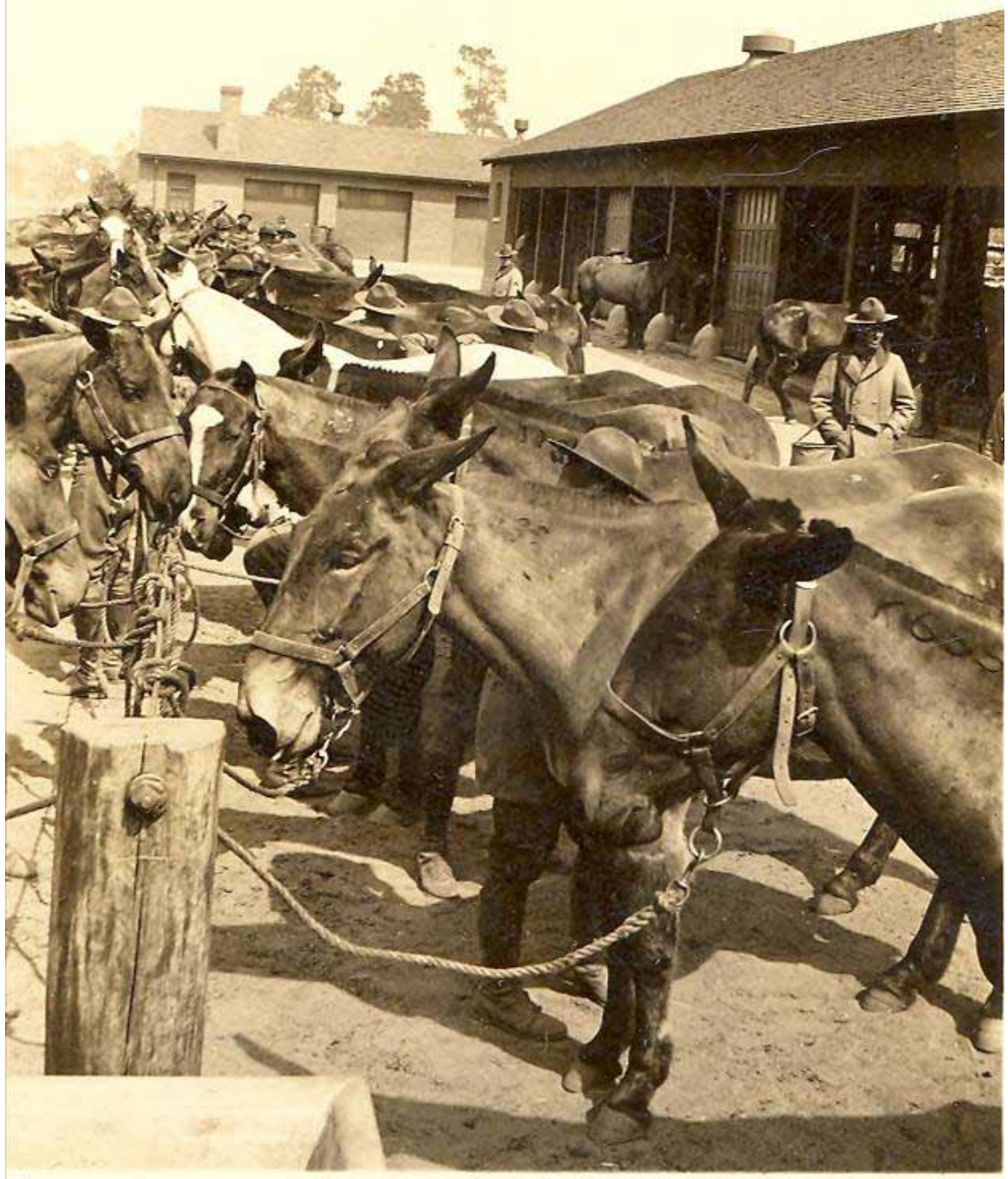

Figure 86. Horses and mules in mule bam area, undated (Fort Bragg Cultural Resources). 


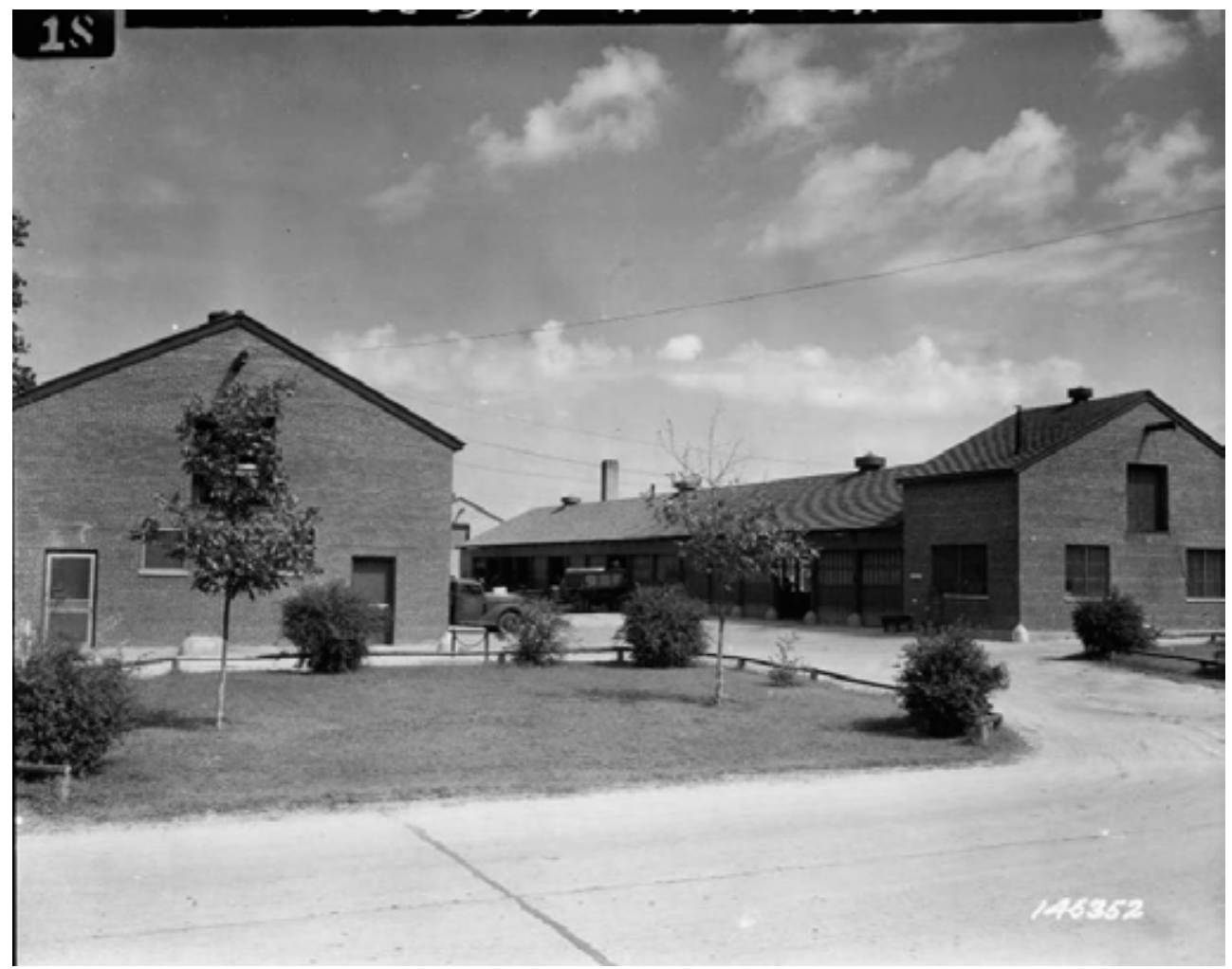

Figure 87. Former mule bams converted to the Motor Transport District, 1942 (NARA111-SC box 92 146352).

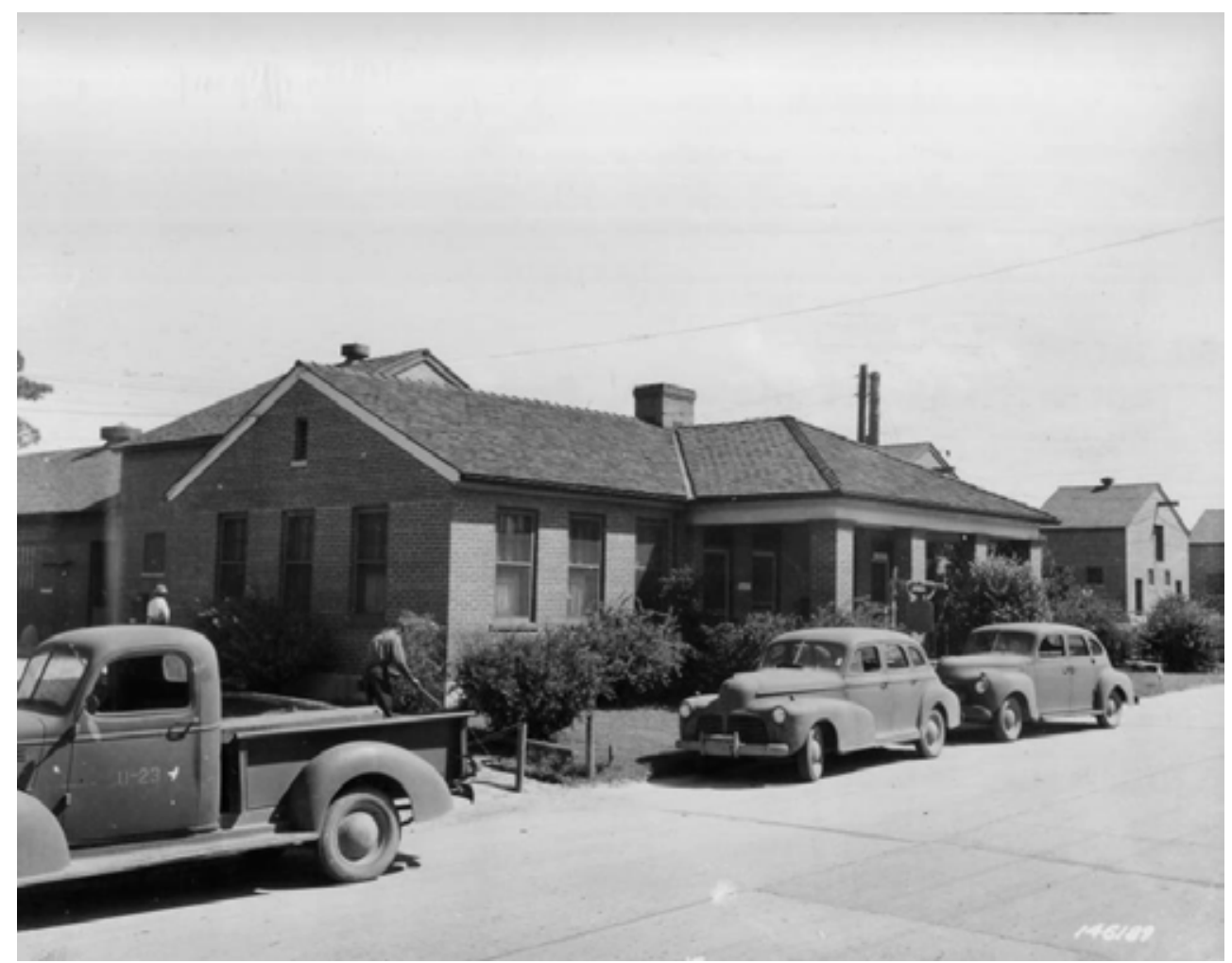

Figure 88. Former Stable Guard Quarters converted to the Motor Transport District, 1942 (NARA111-SC box 92 146189). 


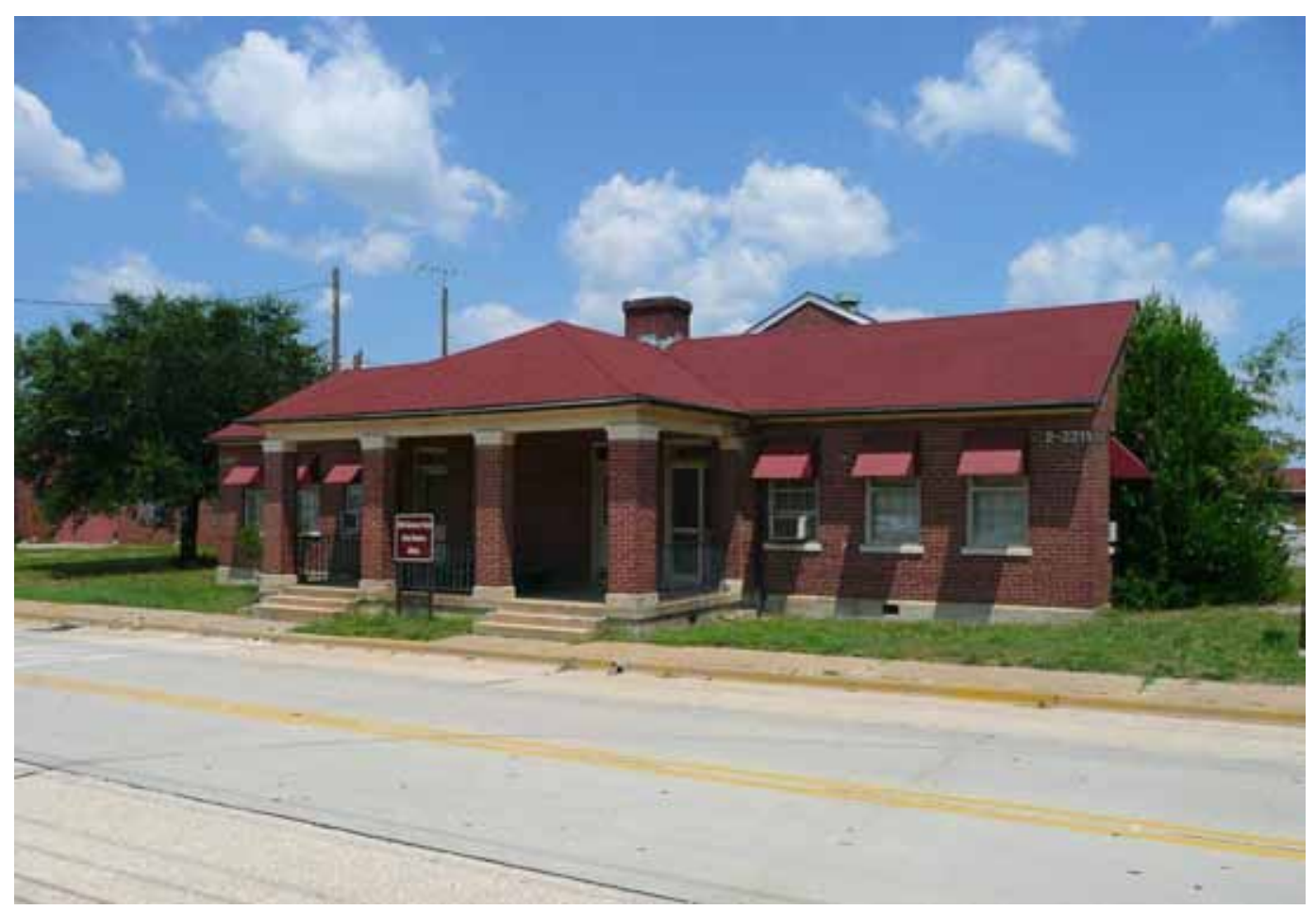

Figure 89. Former Stable Guard Quarters now administrative space, 2009 (ERDC-CERL).

\section{Existing Conditions}

The layout of the mule barns remains much as it was in the 1930s-rows of barns arranged on a grid within the block bounded by Woodruff, Reilly, Letterman, and J ackson Streets-although by the 1960s several new buildings had been constructed in the central open area. The purpose of the barns has changed from housing animals to accommodating the motor pool, general storage, and now, even retail. Because of this shift in use, the spaces between the barns have been paved for parking (Figure 90).

There is no formal landscape design around the mule barns resulting in sparse vegetation. There are some street trees lining the block on the west and along the southeast corner, while the rest of the area has trees scattered throughout, these trees are mostly unkempt, "volunteer" trees. 


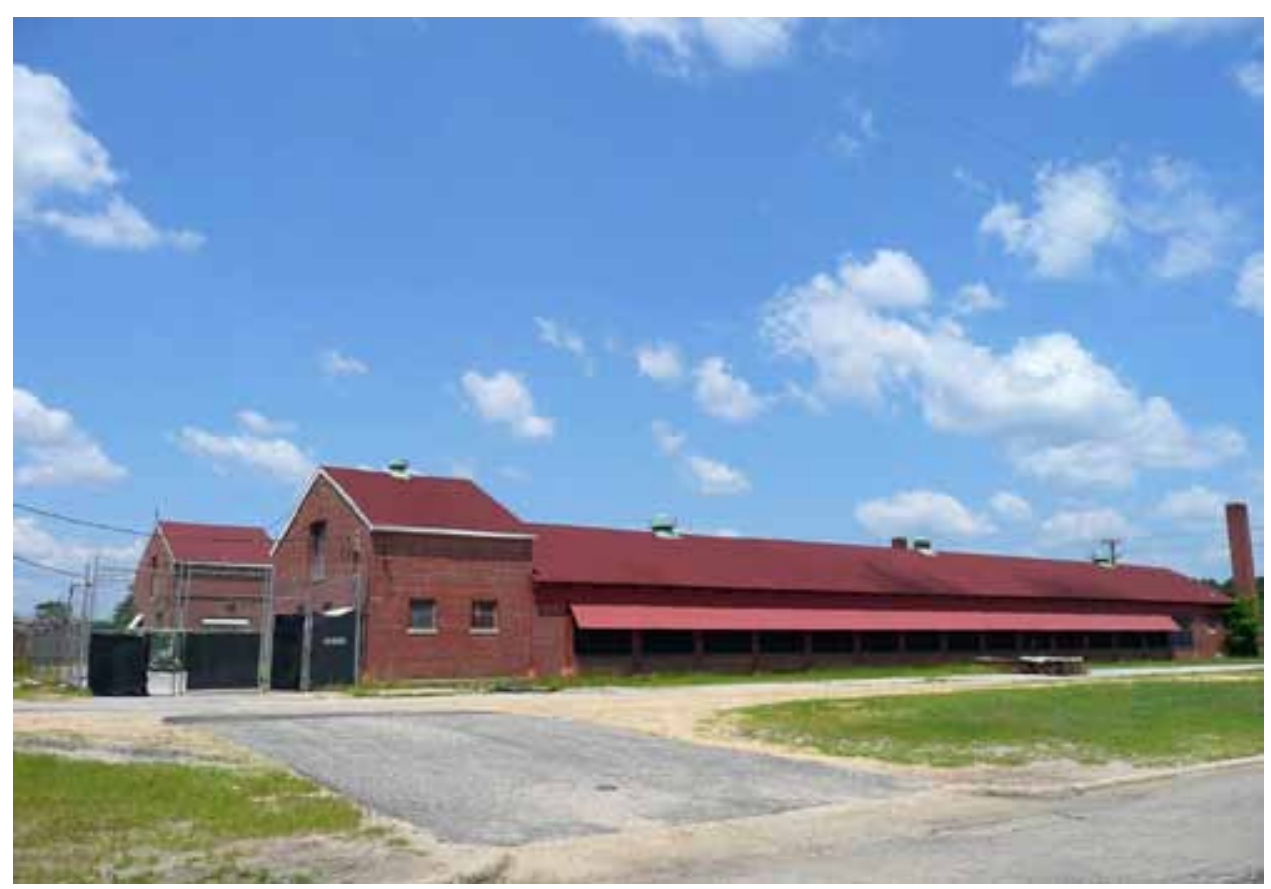

Figure 90. Example of existing landscape around the mule bams, 2009 (ERDC-CERL).

\section{Design Recommendations}

- Maintain the original organizing grid of buildings when possible.

- While there is no historic planting plan for the area, a minimal planting strategy should be implemented. The utility of the barns should be retained, but trees and shrubs can be used to delineate subareas; e.g., the quarters and the retail space can be emphasized with vegetation.

- Street trees should line the block per the overall guidelines for the historic district. See Appendix B for the 1933 standardized street tree planting guidelines.

\section{Residential Areas}

\section{Normandy Heights}

Normandy Heights was constructed in the late 1920s and into the mid1930s. Originally laid out as the Officers' housing area, it incorporated a geometric street layout surrounding the existing parade field. Planned according to Beaux Arts principles, the neighborhood has a hierarchy of streets and alleys and open spaces. In addition to Officers' housing, the area also included the Bachelor Officers' Quarters, Officers' Club, the Post Chapel, and was bounded on the southeast by Ryder Golf Course. Normandy Heights is still Officers' housing and retains its formal organization (Figure 91). 


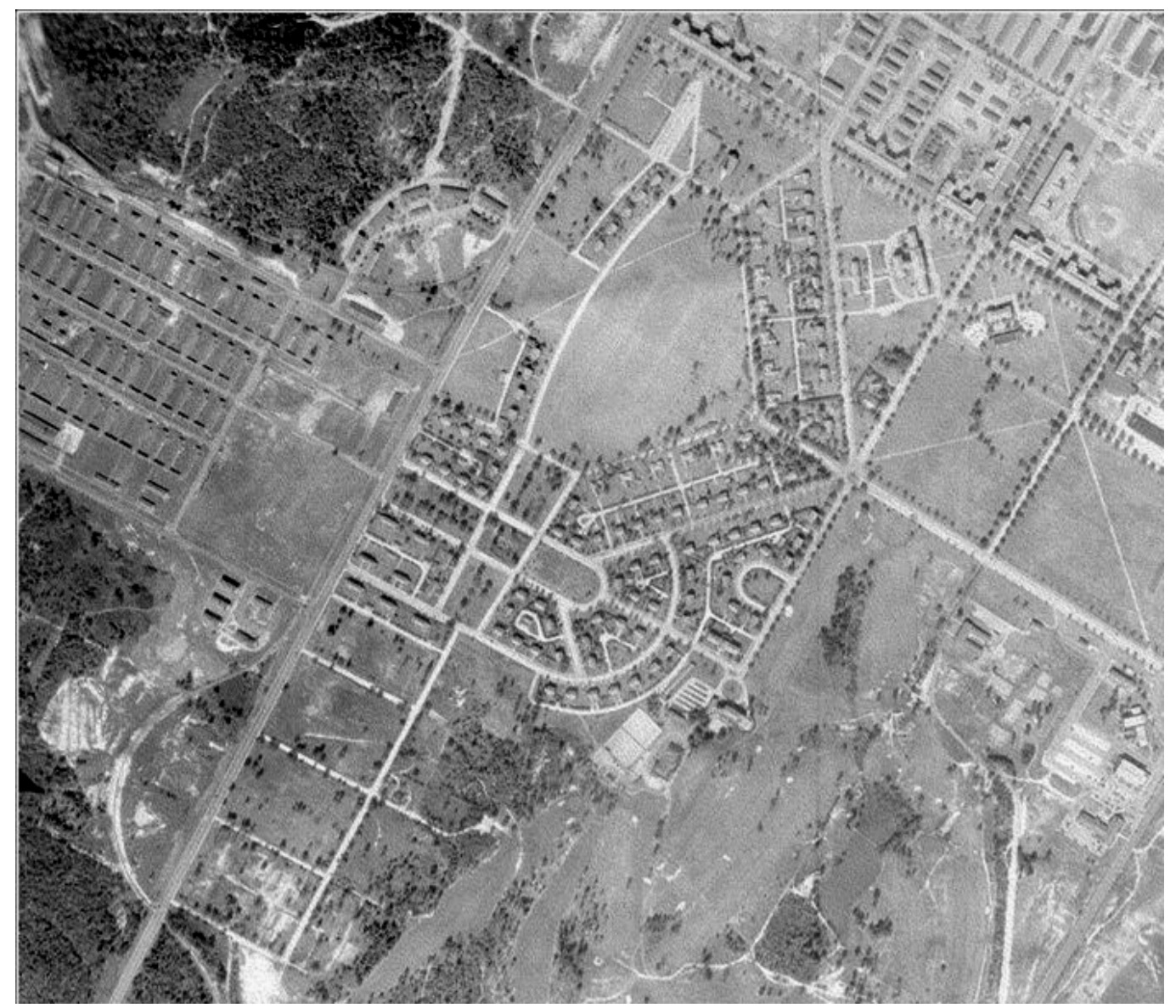

Figure 91. Normandy Heights neighborhood, 1946 (Fort Bragg Cultural Resources).

\section{Dupont Plaza}

Dupont Plaza is Normandy Heights' primary open space and park. Located south of the parade field its cruciform shape is the central feature of the southern half of Normandy Heights.

\section{Historic Characteristics}

- The formal organization of the neighborhood reflects the ideas of $1930 \mathrm{~s}$ city planning, emphasizing open spaces. The neighborhood also reflects Beaux Arts style designs with the street layout in strict geometries.

- The Officers' housing of Normandy Heights was planned for a prominent, central location in the cantonment. It is bisected by the original entrance road and surrounds the ceremonial parade field.

- The park-like setting of the original cantonment is illustrated in the neighborhood's wide, tree lined streets, low housing densities, and the use of alleyways for vehicle parking. 
- The architectural style of the neighborhood is Spanish Eclectic. Although there are three different house plans, they all have stucco exteriors and red terra cotta tile roofs, which add to the cohesiveness of the housing area. (For lists of architectural features of each housing type see the Fort Bragg Old Post Historic District Design Guidelines (Fort Bragg, NC, Directorate of Public Works 2007).

- The vegetation around the houses was fairly uniform, reflecting the standardized planting plans of the 1930s (Figure 92). Evergreen shrubs are the dominant plant choice used as foundation plantings and hedges (Figures 93 and 94). Appendix B includes the Army's 1933 standardized planting plans.

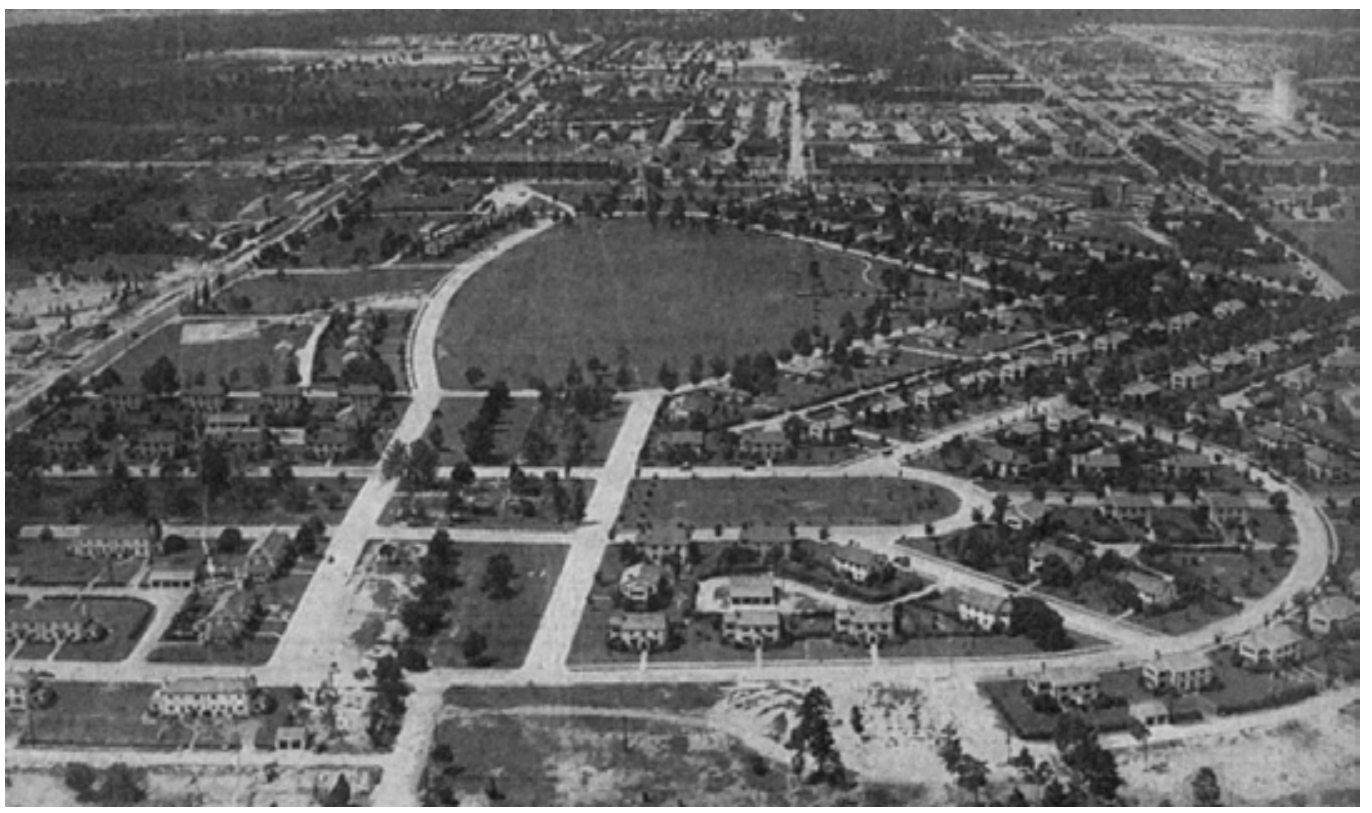

Figure 92. Aerial view of the Normandy Heights neighborhood, 1930s (Fort Bragg Cultural Resources). 


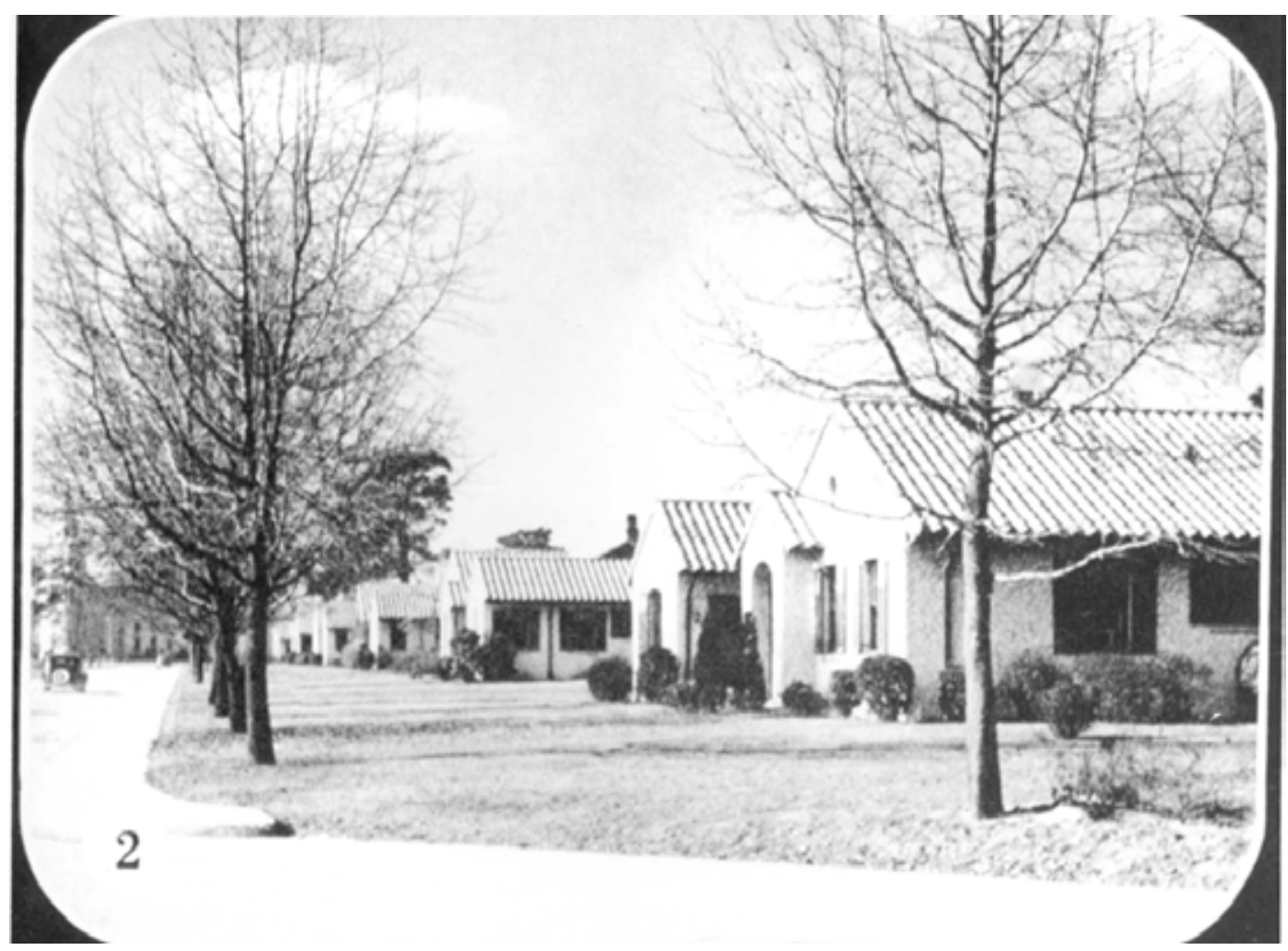

Figure 93. Ranch style housing in Normandy Heights, 1941 (Fort Bragg Cultural Resources).

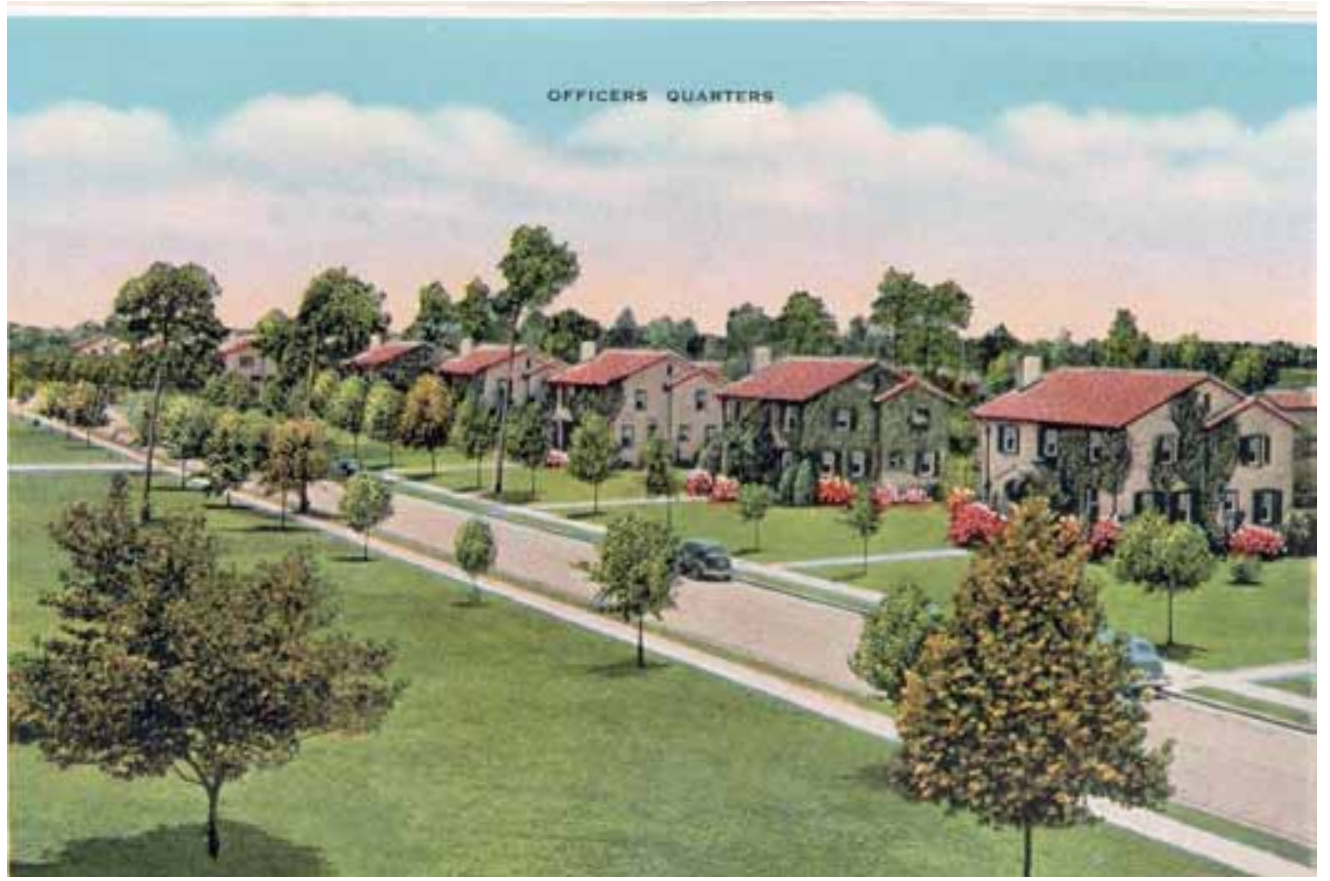

Figure 94. Postcard illustrating officers' quarters with plantings, 1940s (Fort Bragg Cultural Resources). 


\section{Existing Conditions}

Normandy Heights still functions as Officers' housing. The officers' quarters, for the most part, are in very good condition and the vegetation throughout the neighborhood is well maintained (Figures 95- 97). The area has mature street trees along the main streets and evergreen hedges lining the alleys. The open spaces in the neighborhood have trees scattered throughout in varying degrees of density. Overall, the neighborhood retains its park-like qualities.

Currently Picerne Housing provides landscape support for the residences in the historic district. Residents may make changes, but they are given responsibility guidelines at move in which details acceptable modifications to the landscape. Generally the landscaping around the houses consists of small- to medium-sized evergreen shrubs lining the foundations and turf grass lawns. Some houses have ornamental trees and some houses are separated by evergreen hedges. Most residences have fences, vegetation, or a combination of both visually separating the front and rear yards.

Dupont Plaza remains an open area and park in Normandy Heights. The cruciform form of the plaza and park divides the land use into three general sections. The east and west areas are open with scatterings of trees while the north and south areas are heavily wooded. The central area is a playground. 


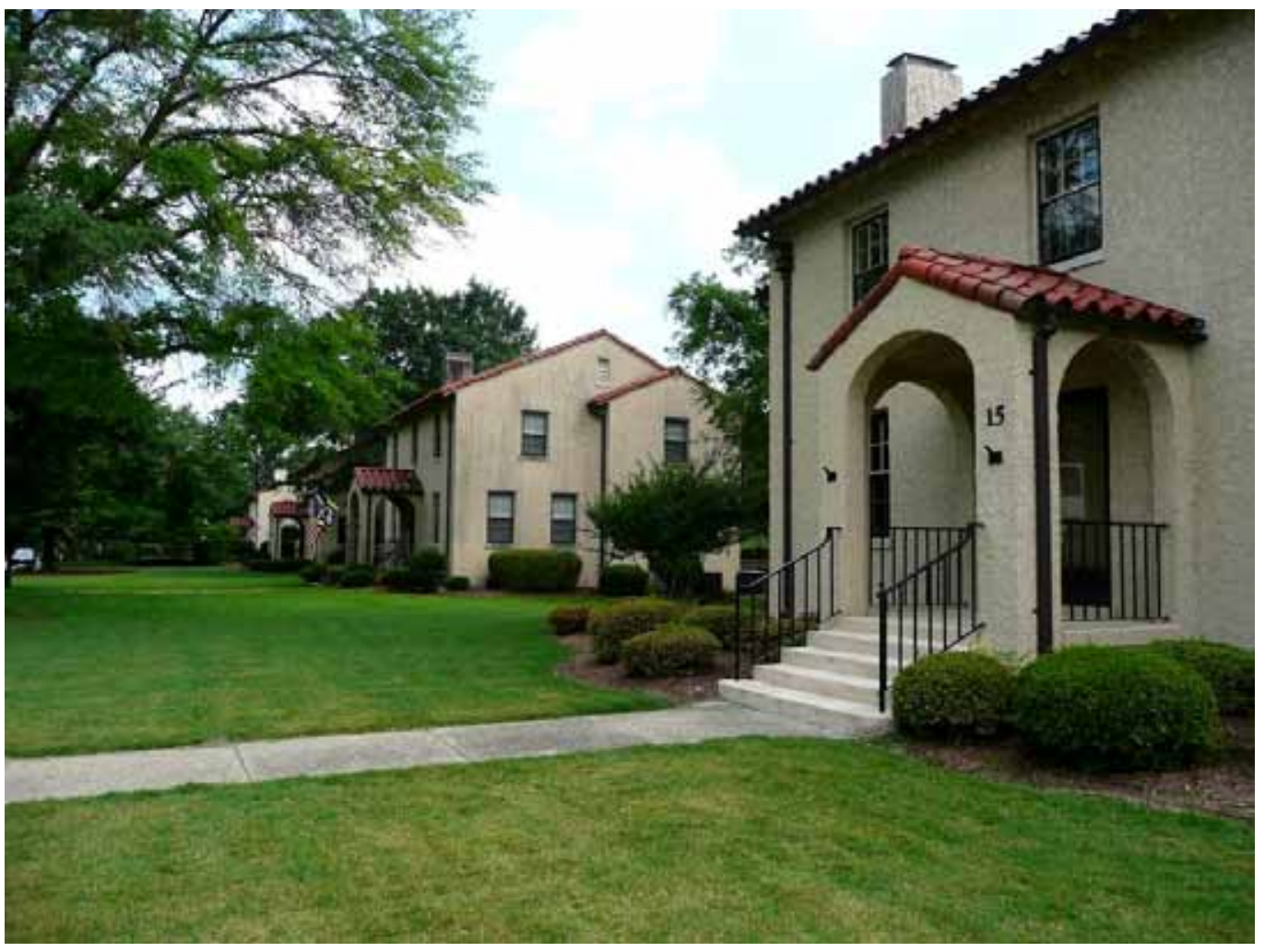

Figure 95. Normandy Heights Officers' Quarters, showing uniform, well-maintained foundation plantings and wide front lawns, 2009 (ERDC-CERL).

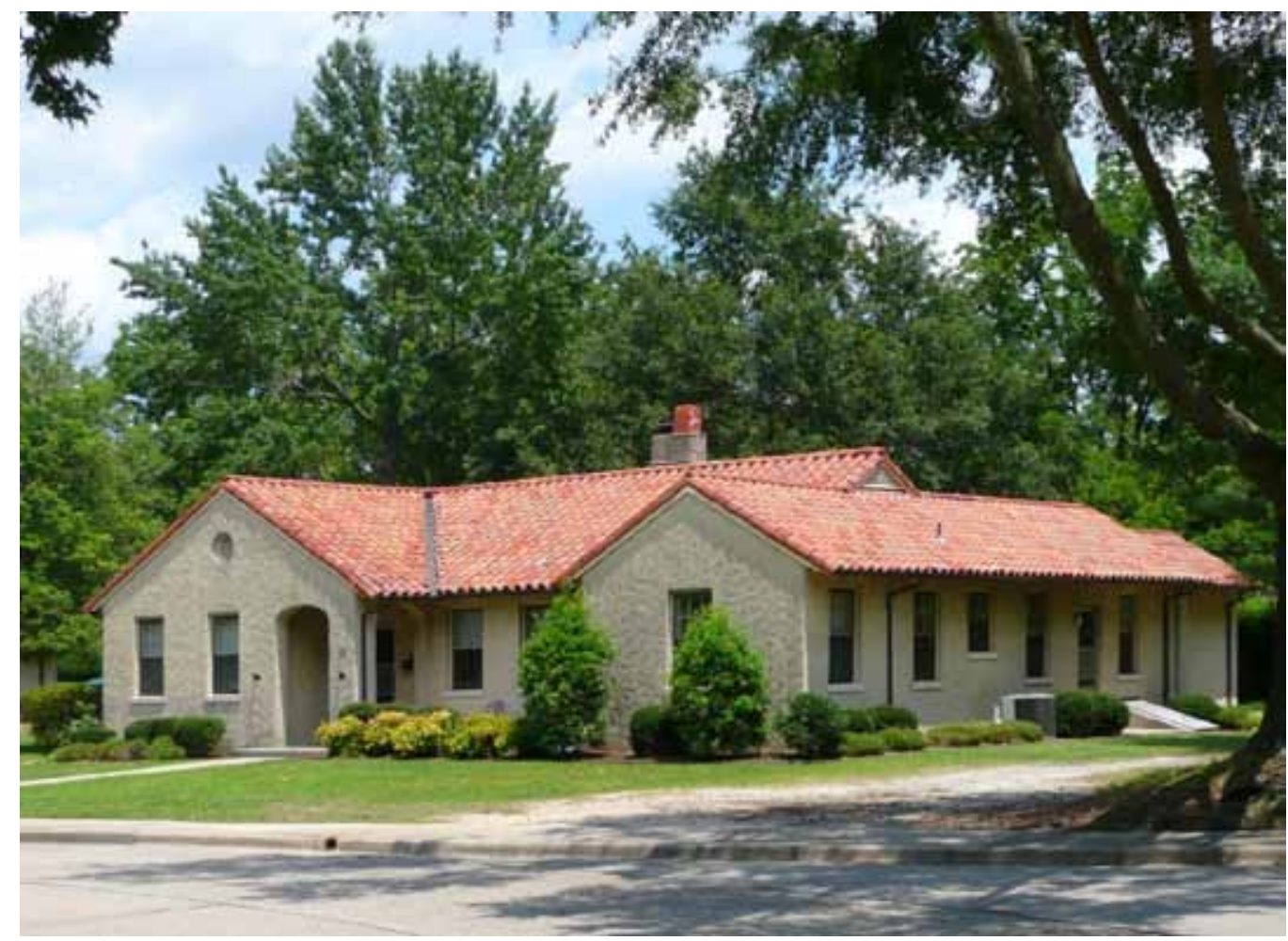

Figure 96. Nomandy Heights ranch-style house type showing orderly foundation plantings, 2009 (ERDC-CERL). 


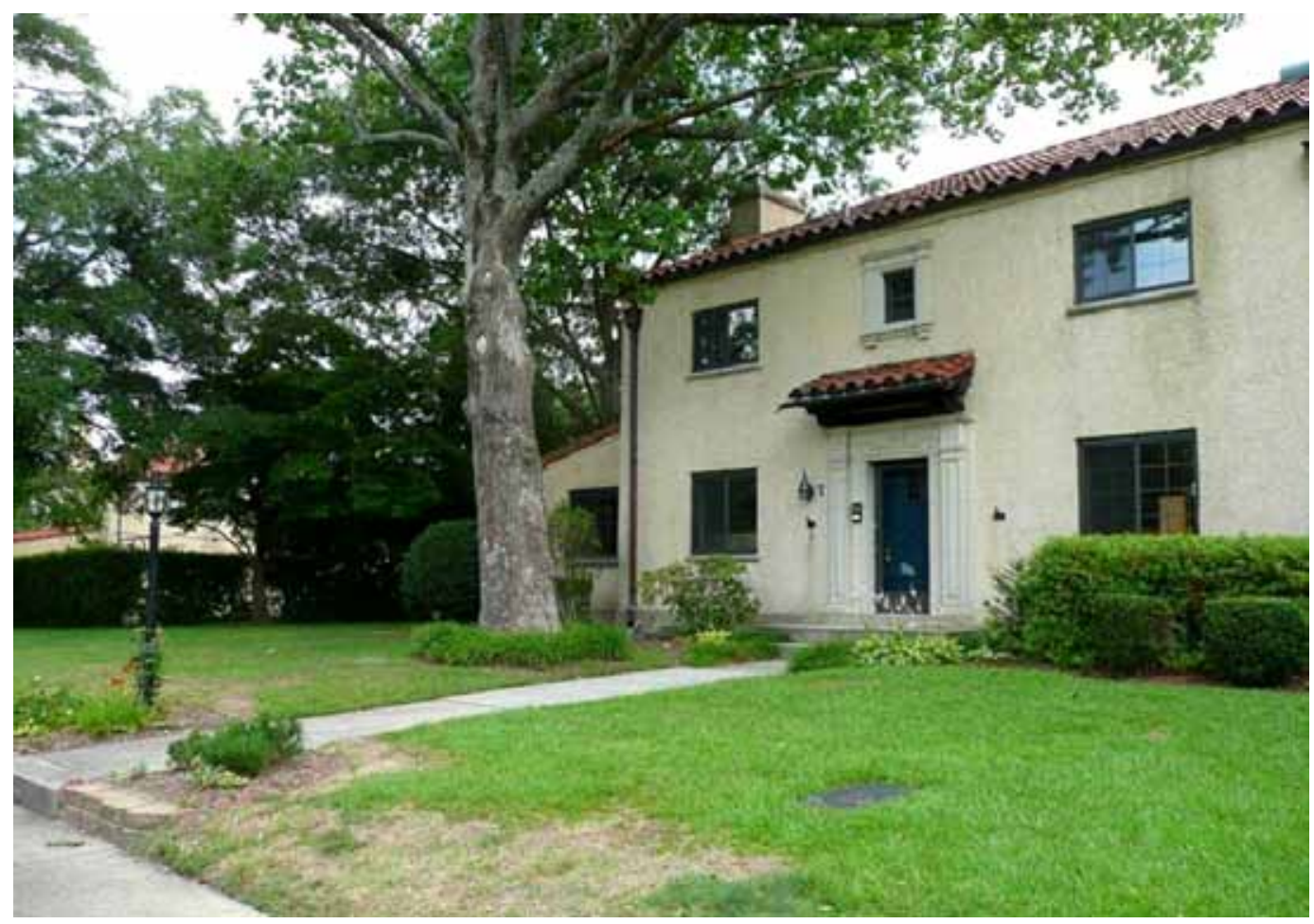

Figure 97. Normandy Heights duplex showing a variety of vegetation types, 2009 (ERDC-CERL).

\section{Design Recommendations}

- Normandy Heights' layout is a distinct element of Fort Bragg. Therefore, the spatial characteristics of the area should be maintained; this includes the network of streets and alleys, the architectural style of the buildings, street tree density, and vegetation patterns.

- Normandy Heights is prominently located. Functional spaces, such as backyards, patios and clotheslines should be screened with vegetation.

- A consistent palette of plant material, mulch, and edgings should be used. The housing privatization partner should make sure individual residential plantings are consistent with the overall character of the neighborhood. In general, the plantings should be of similar size, massing, and form (Appendix B).

- It is ideal to have a mix of deciduous and evergreen plants. Select plants that have different flowering times, plants that provide winter interest, and a variety of textures and habits. See Appendix C for the 1933 standardized plant list.

- Plants should be planted far enough from the building to ensure their mature size will not damage the façade or foundation. The mature size of a plant should also be considered in regard to the scale of the house; 
larger houses can accept larger plants, while smaller houses are overwhelmed by out of scale vegetation.

- Vegetation should be selected that requires minimal maintenance. When possible choose varieties native to the region. Groundcovers should be used to control weeds under larger plants (Appendix C).

- Dupont Plaza and park should remain as an open area in Normandy Heights.

Figures 98- 113 show examples of possible planting designs for the varying house types in the Normandy Heights neighborhood. The 2010 proposed planting diagrams are based on the Army's 1933 standardized residential planting plans. Although the proposed plans are based on the 1933 planting plans, the new examples incorporate the design recommendations for the Normandy Heights neighborhood outlined in this report. The proposed plans are merely guidelines illustrating possible, historically grounded planting solutions for the residences. The 2010 plans should be consulted if landscaping is to be undertaken; then the designs can guide plant choices and placement. Furthermore, when implementing landscaping changes, it is of primary importance to consider the continuity of the historic neighborhood as well as the context of the residence's existing vegetation. While continuity of style and plant material within each neighborhood is desired, it is not intended that every house be planted using the exact same plants and designs. Although order and uniformity are characteristics of military landscapes, diversified planting designs increase visual interest and highlight the residential area. 


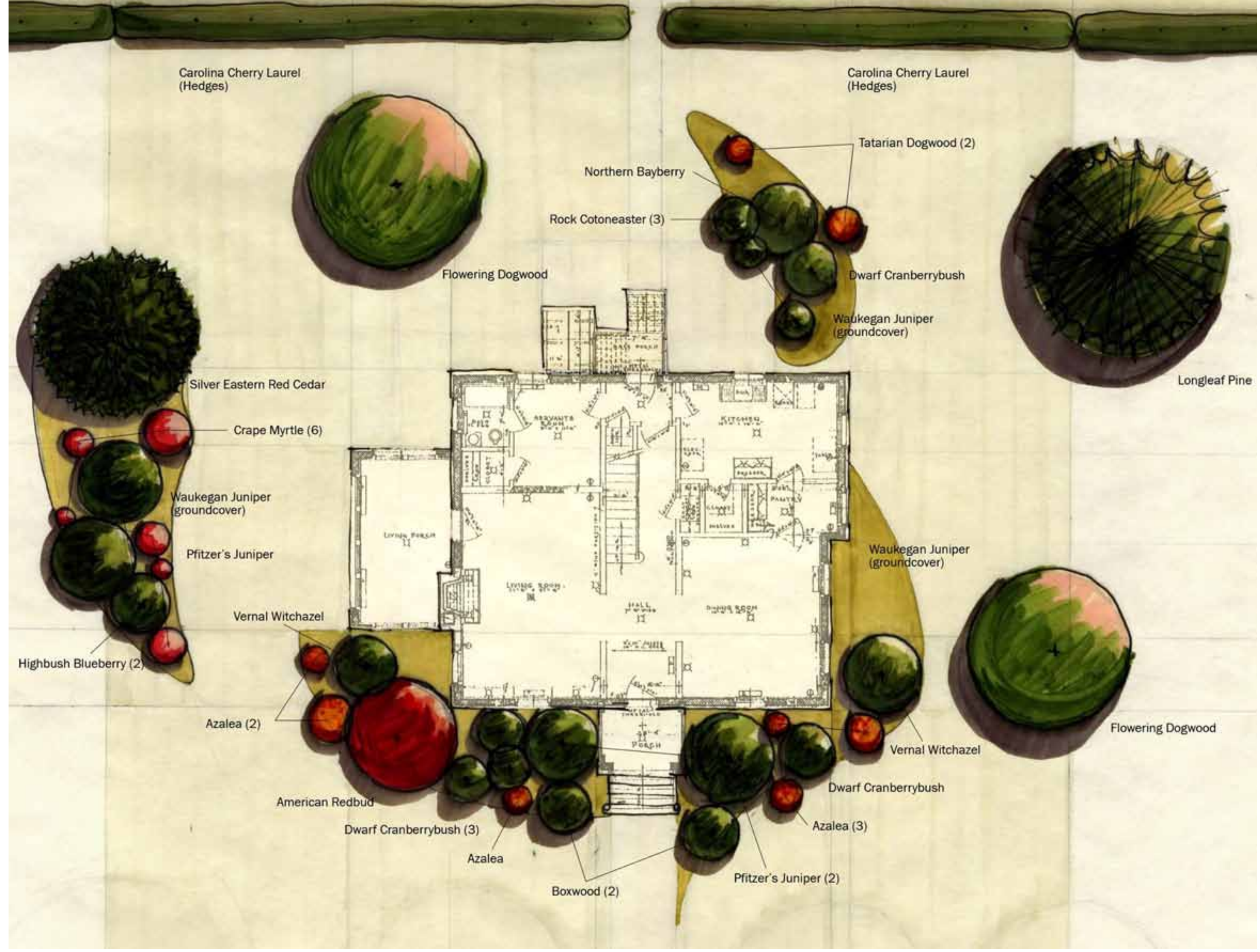

Figure 98. Plan view of proposed planting plan for two-story quarters in Normandy Heights neighborhood, 2010 (ERDC-CERL). 


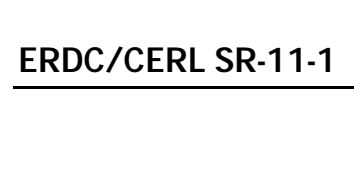




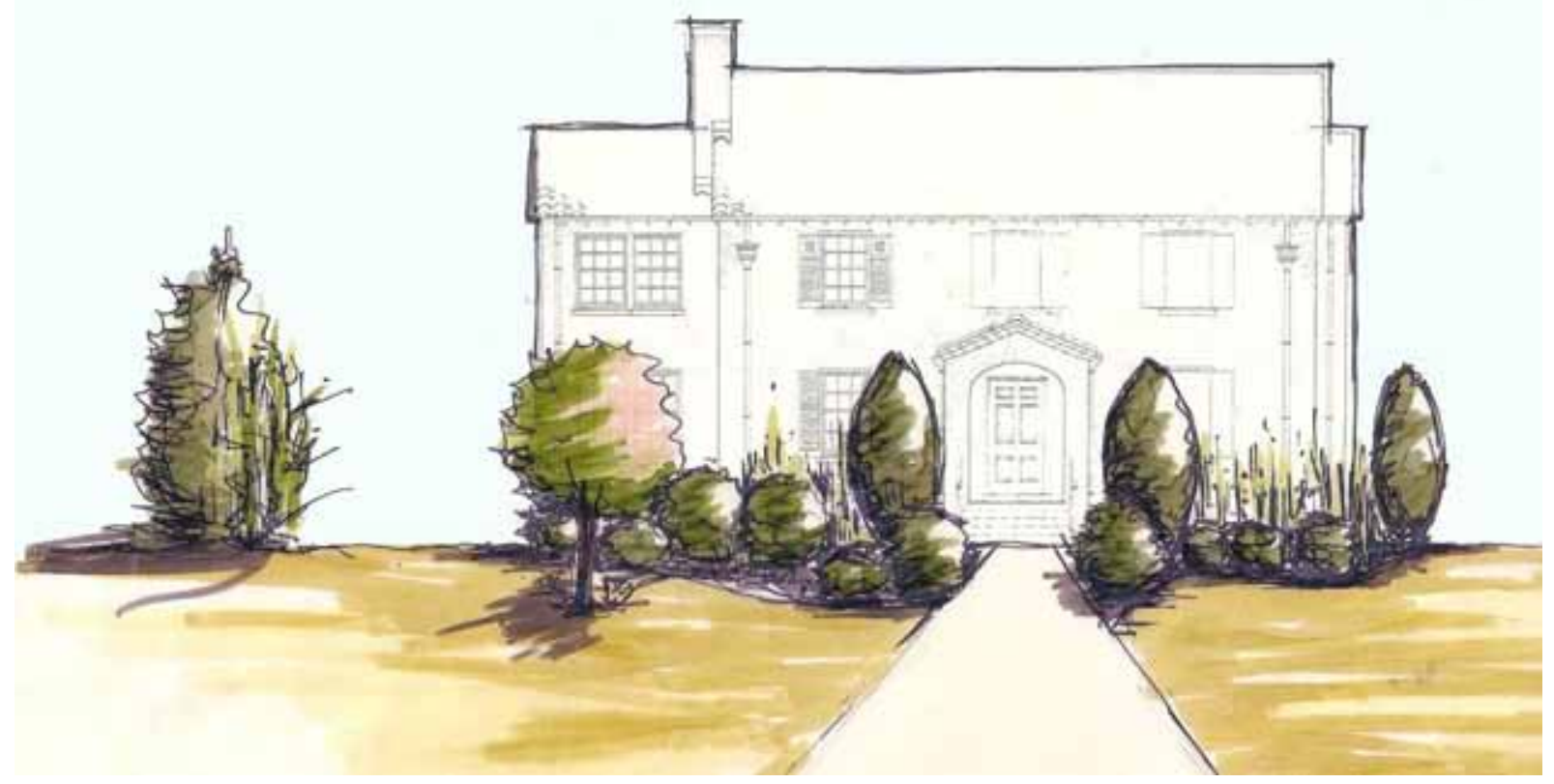

Figure 99. Elevation view of proposed planting plan for two-story quarters in Normandy Heights (ERDC-CERL). 


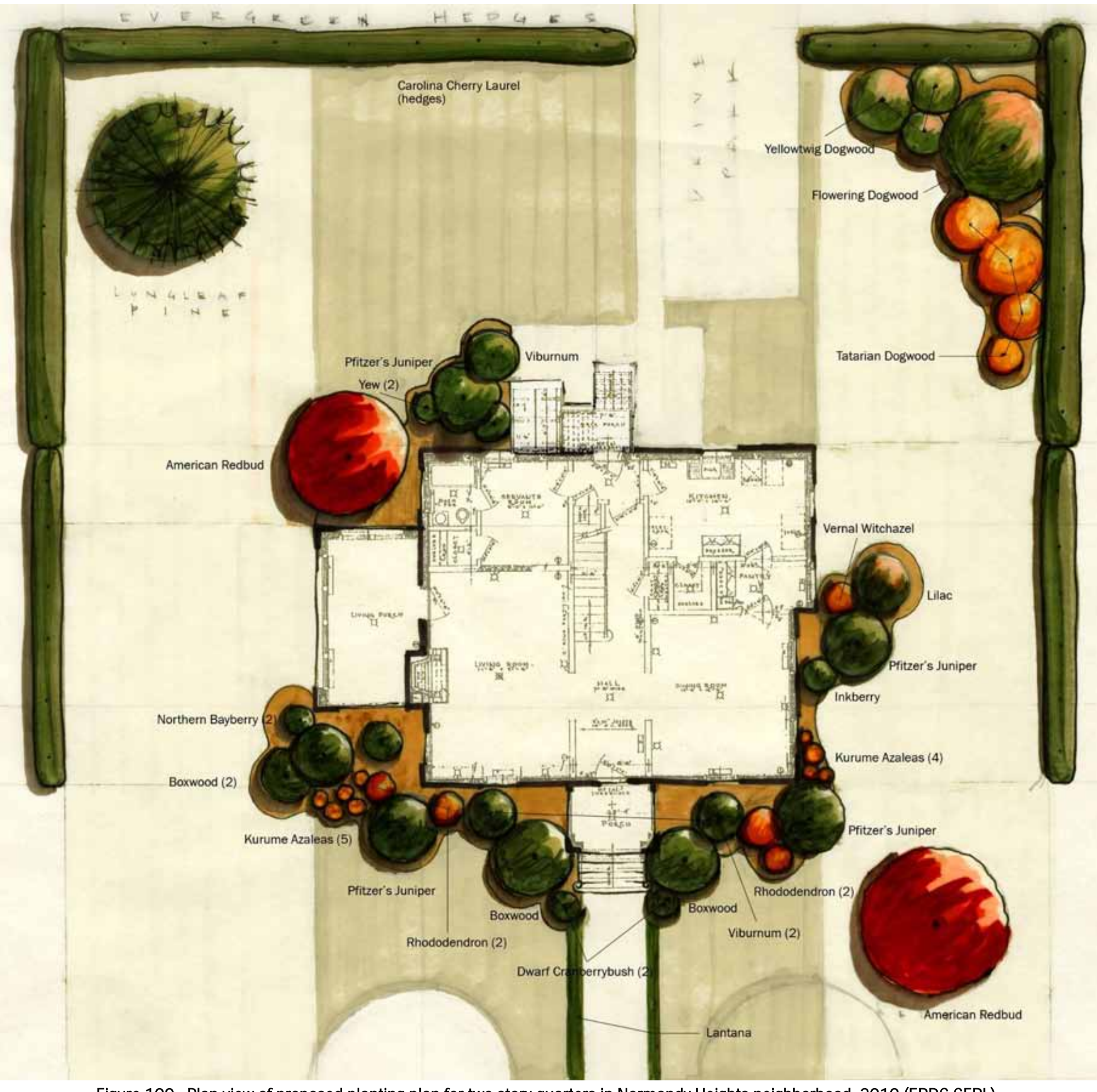

Figure 100. Plan view of proposed planting plan for two-story quarters in Normandy Heights neighborhood, 2010 (ERDC-CERL). 


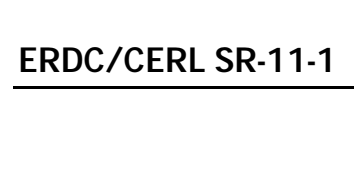




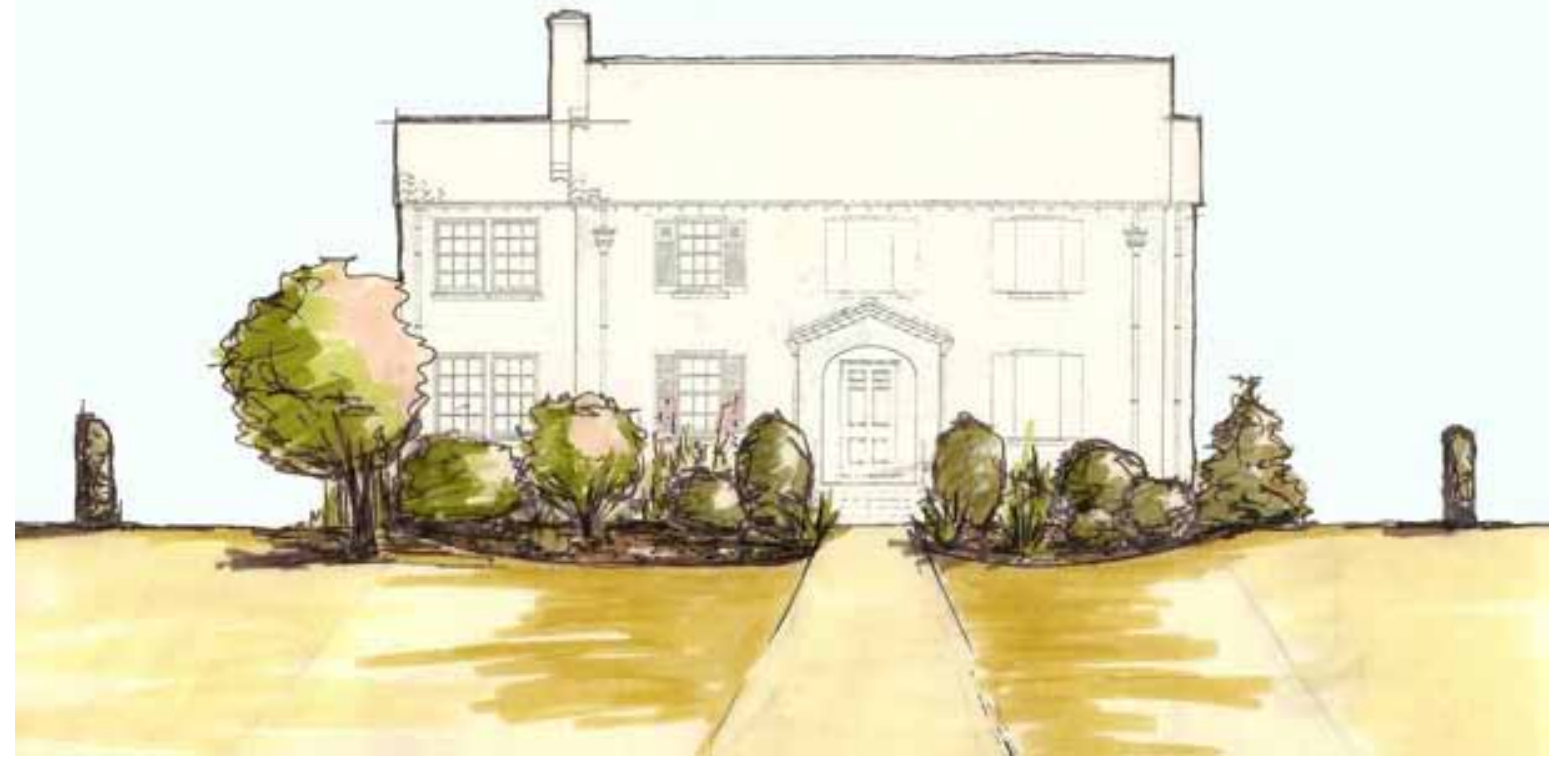

Figure 101. Elevation view of proposed planting plan for two-story quarters in Normandy Heights (ERDC-CERL). 


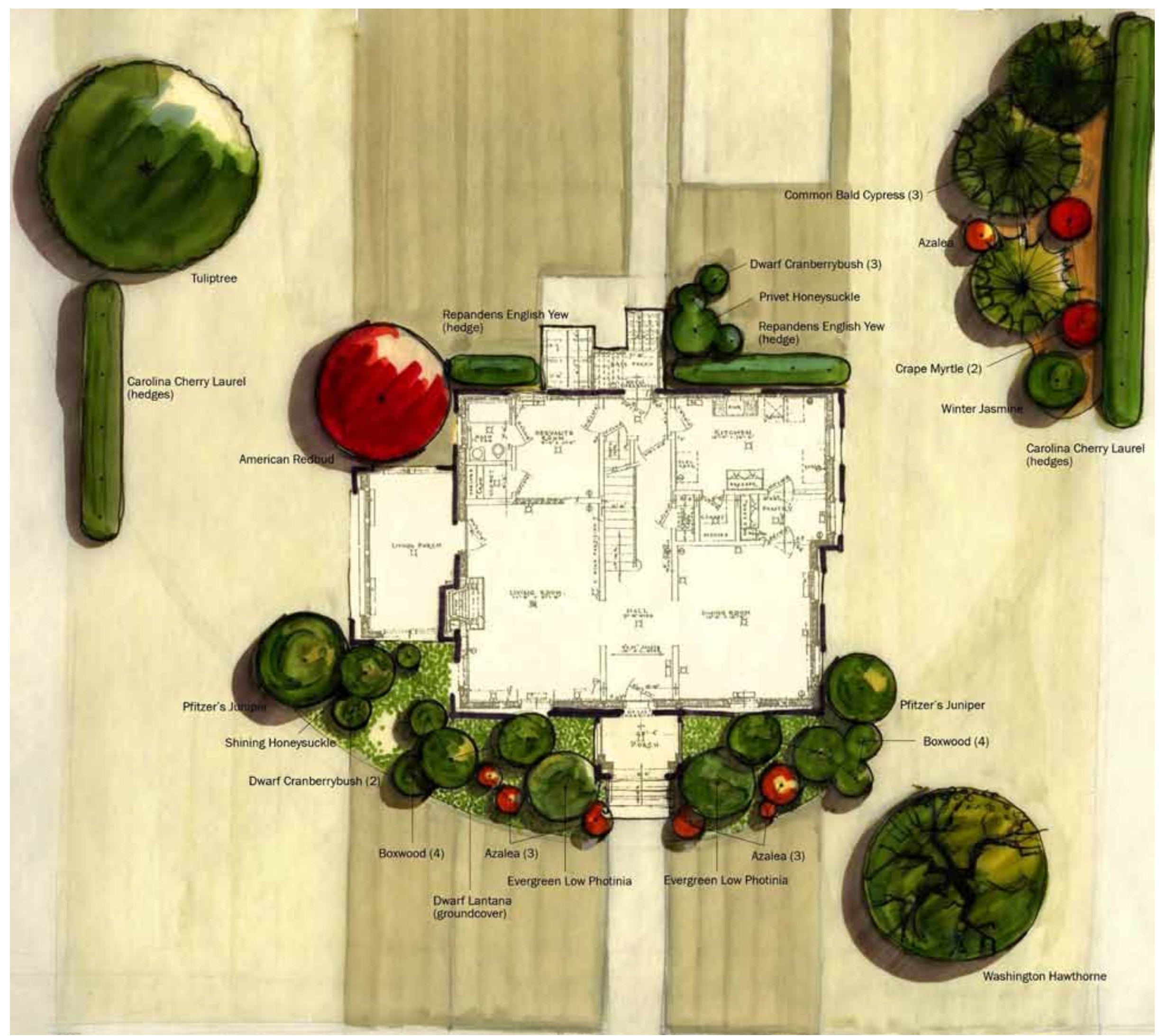

Figure 102. Plan view of proposed planting plan for two-story quarters in Normandy Heights neighborhood, 2010 (ERDC-CERL). 


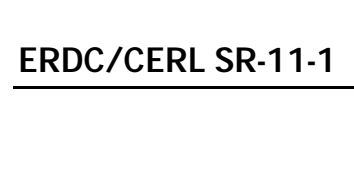




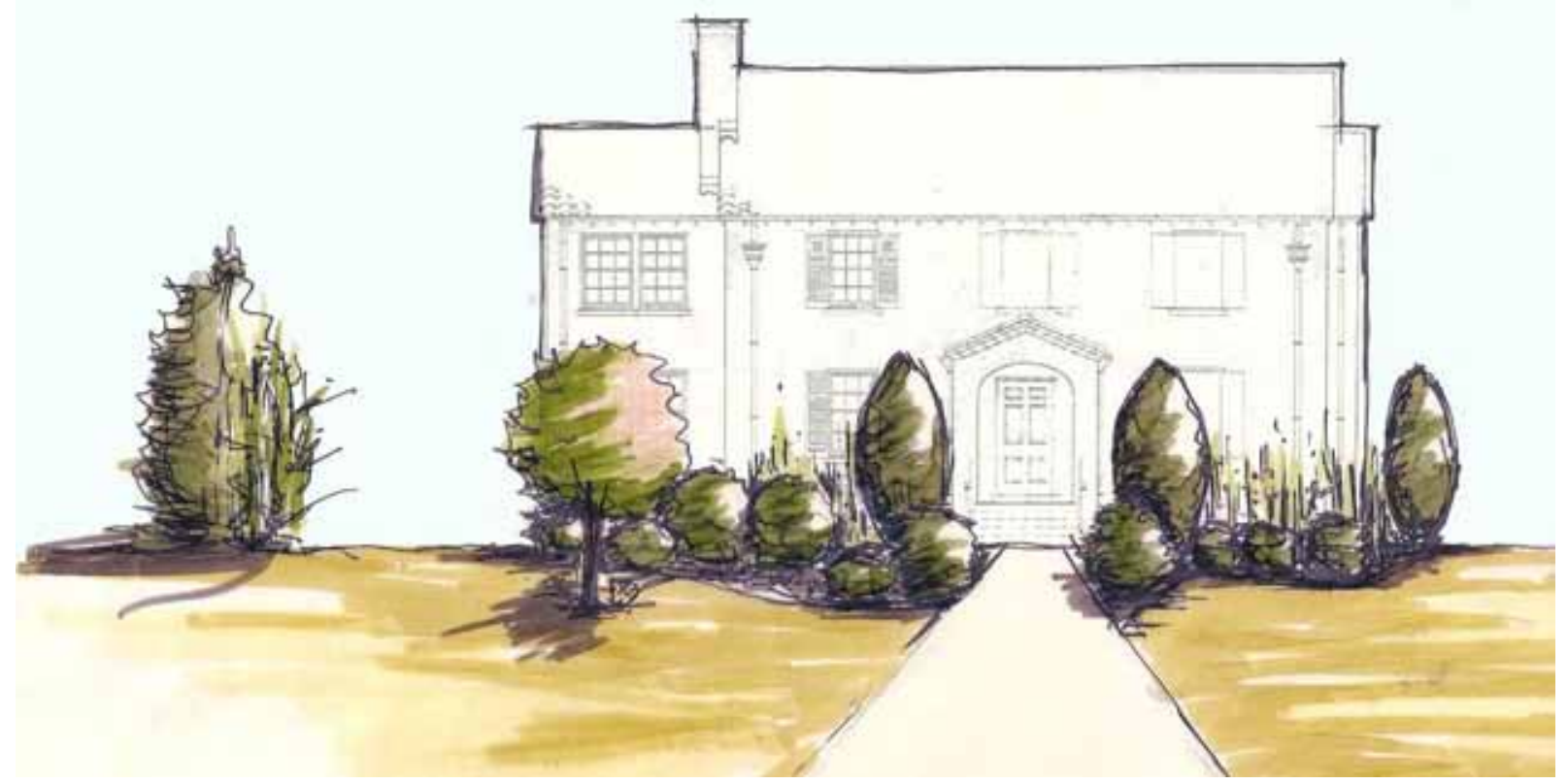

Figure 103. Elevation view of proposed planting plan for two-story quarters in Normandy Heights (ERDC-CERL). 


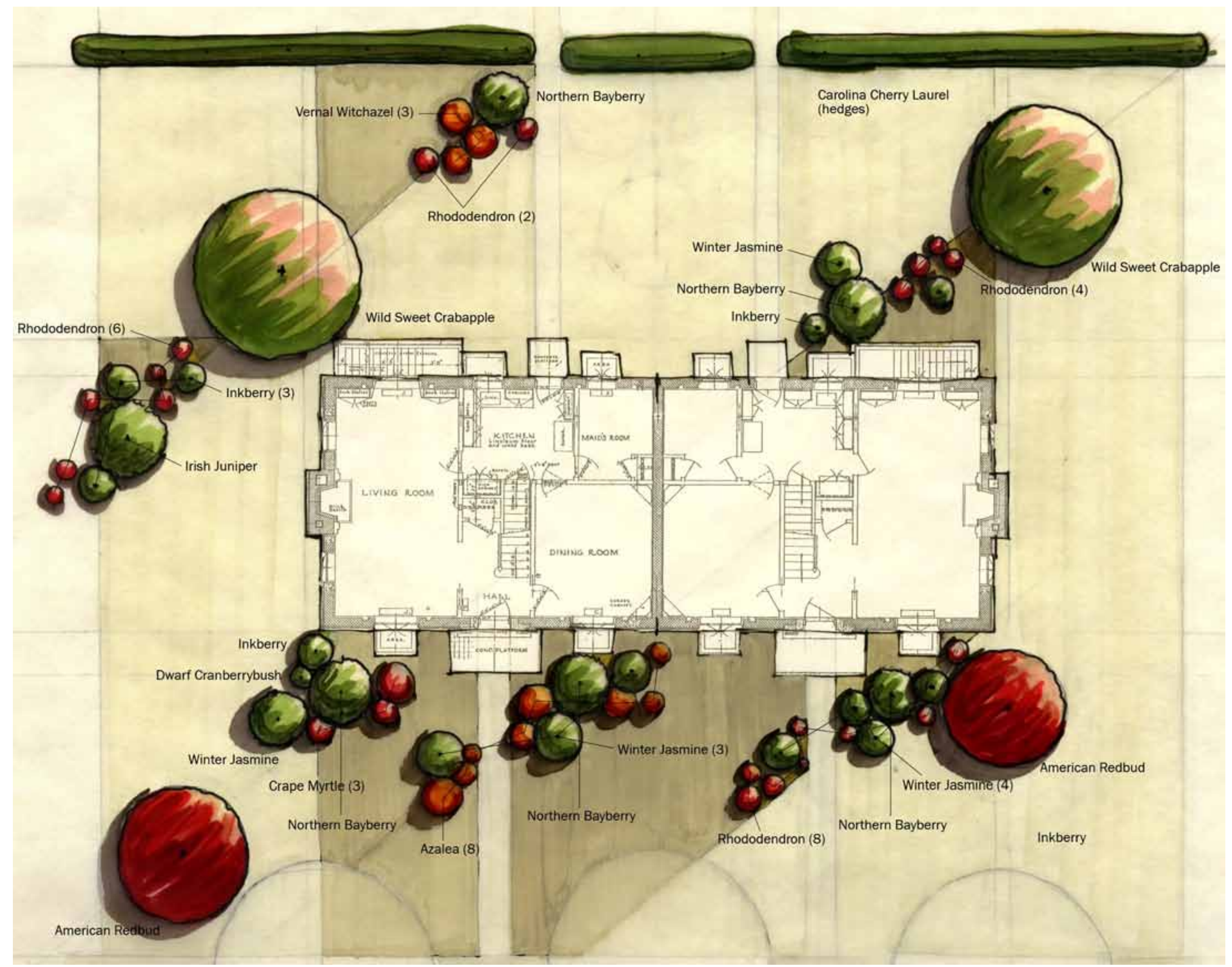

Figure 104. Plan view of proposed planting plan for duplex quarters in Normandy Heights neighborhood, 2010 (ERDC-CERL). 


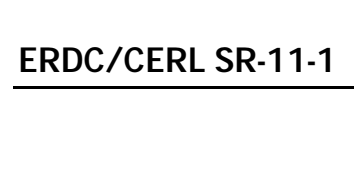




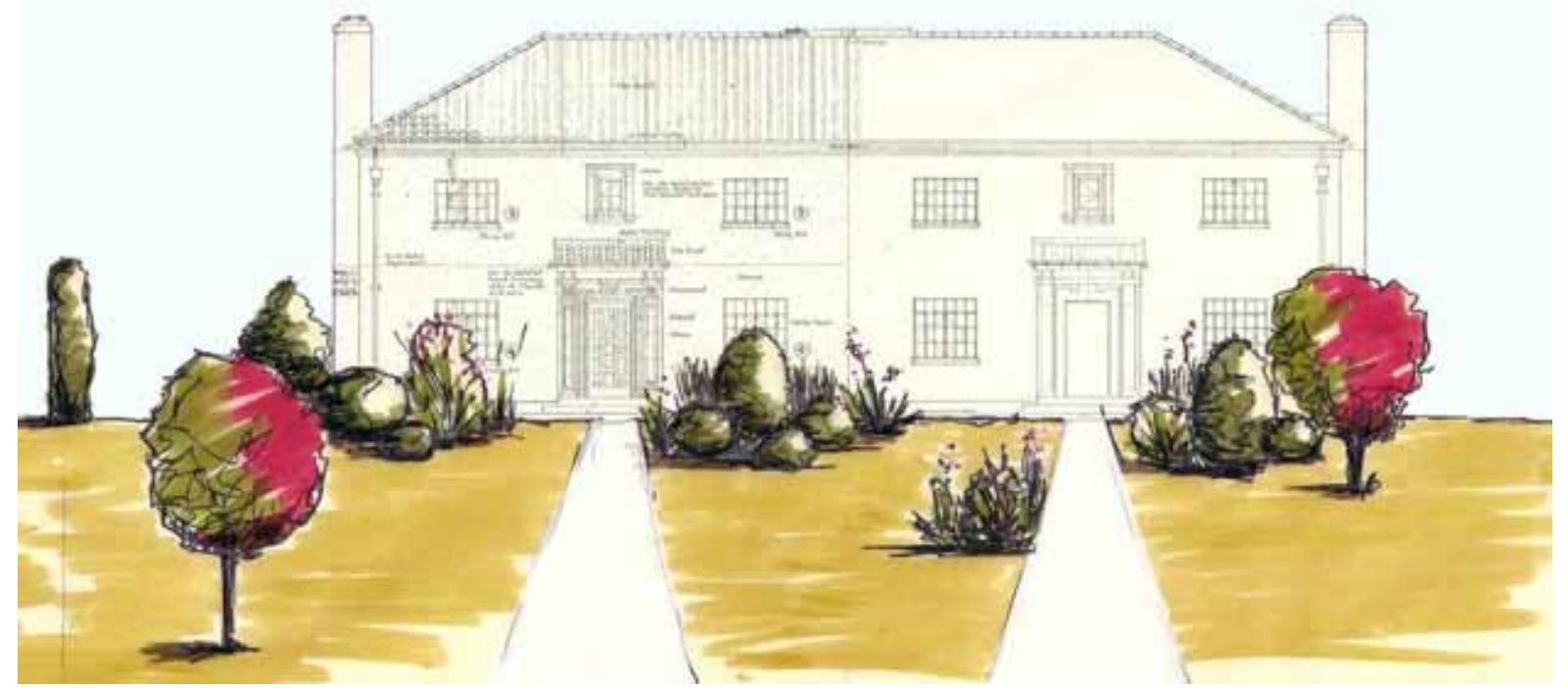

Figure 105. Elevation view of proposed planting plan for duplex quarters in Normandy Heights (ERDC-CERL). 


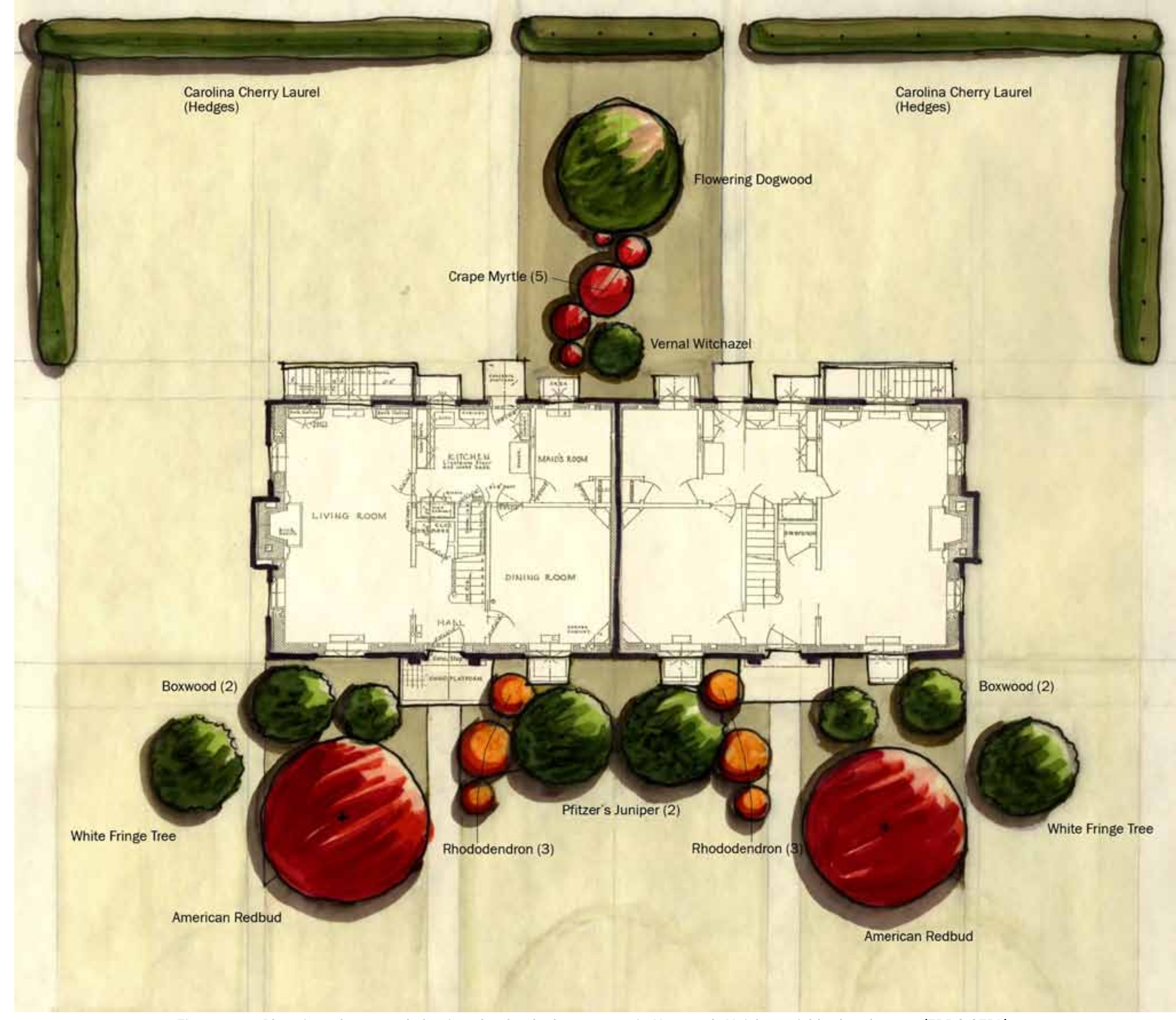

Figure 106. Plan view of proposed planting plan for duplex quarters in Normandy Heights neighborhood, 2010 (ERDC-CERL). 



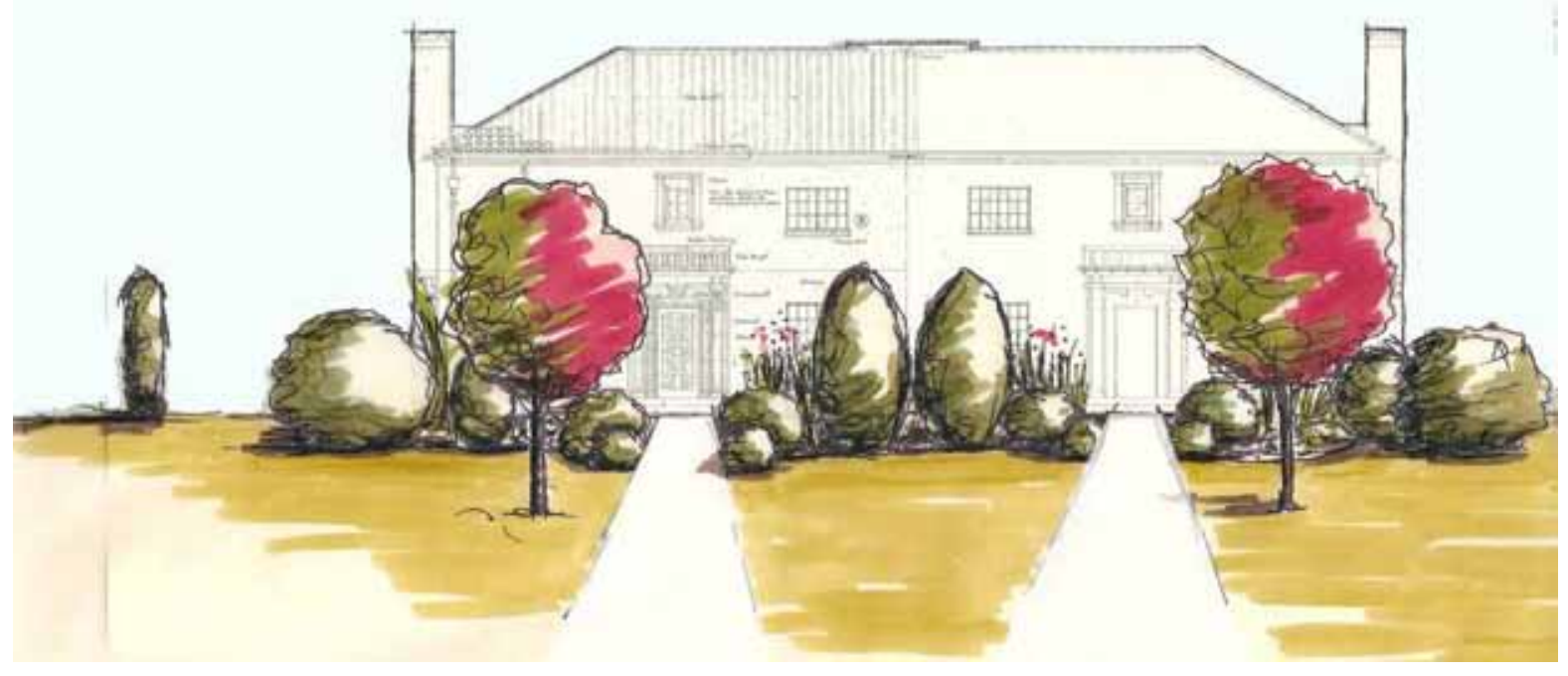

Figure 107. Elevation view of proposed planting plan for duplex quarters in Normandy Heights (ERDC-CERL). 


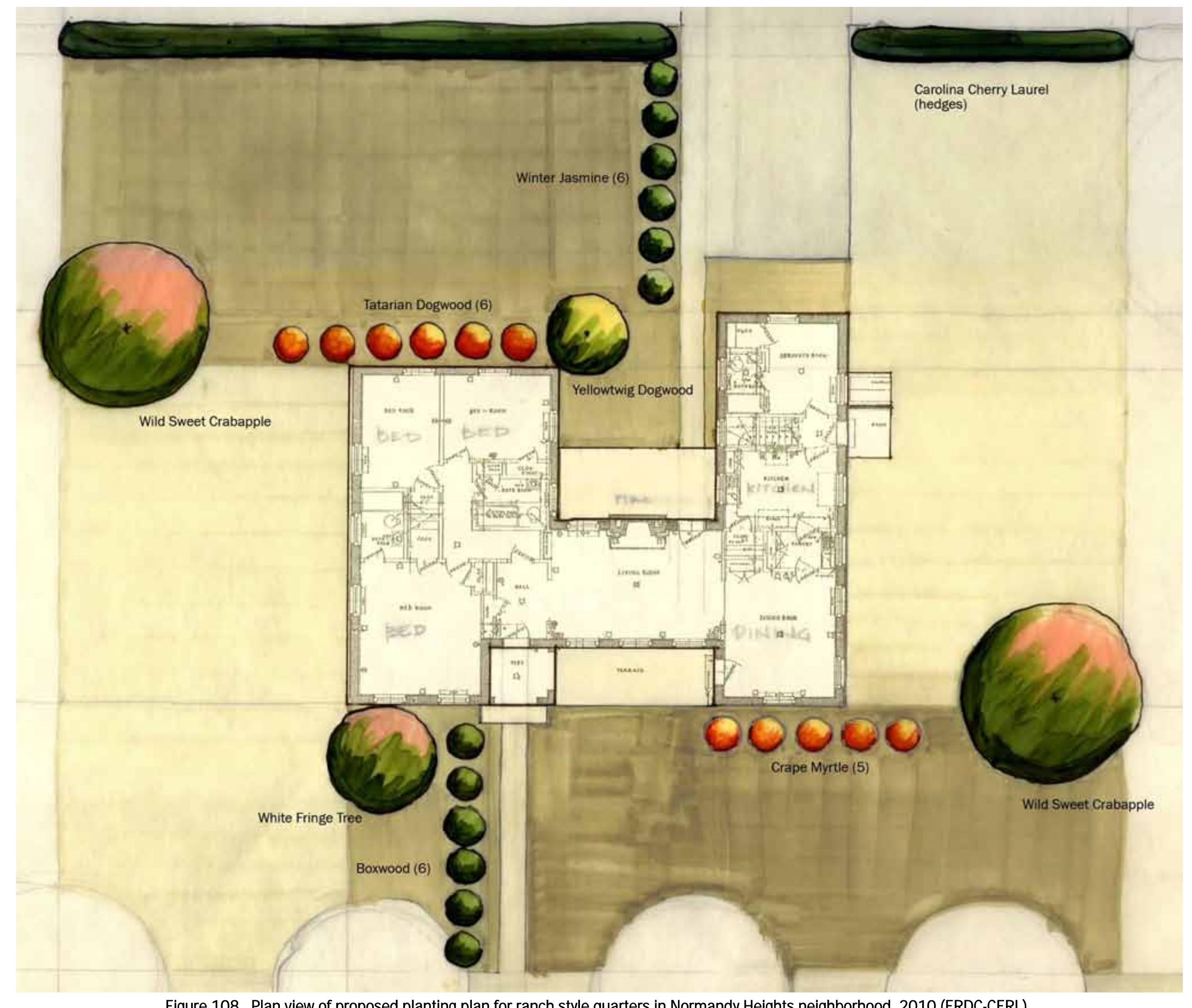

Figure 108. Plan view of proposed planting plan for ranch style quarters in Normandy Heights neighborhood, 2010 (ERDC-CERL). 



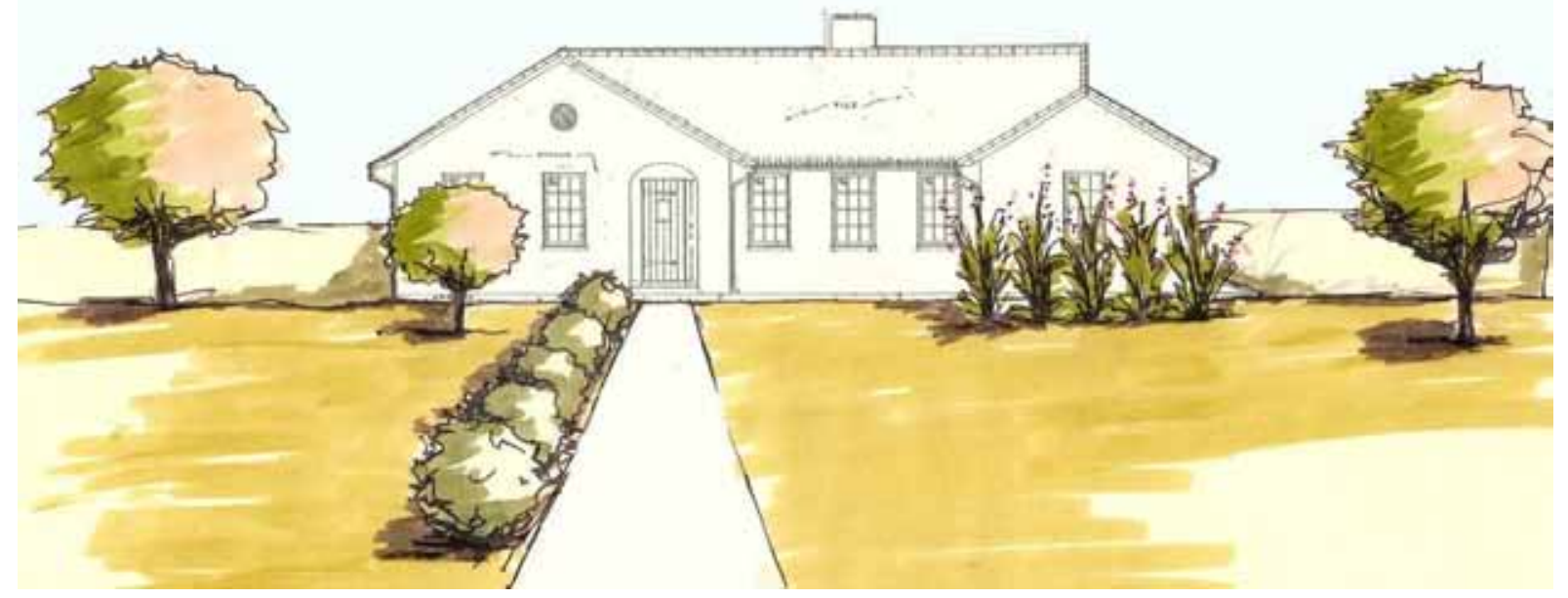

Figure 109. Elevation view of proposed planting plan for ranch-style quarters in Normandy Heights (ERDC-CERL). 


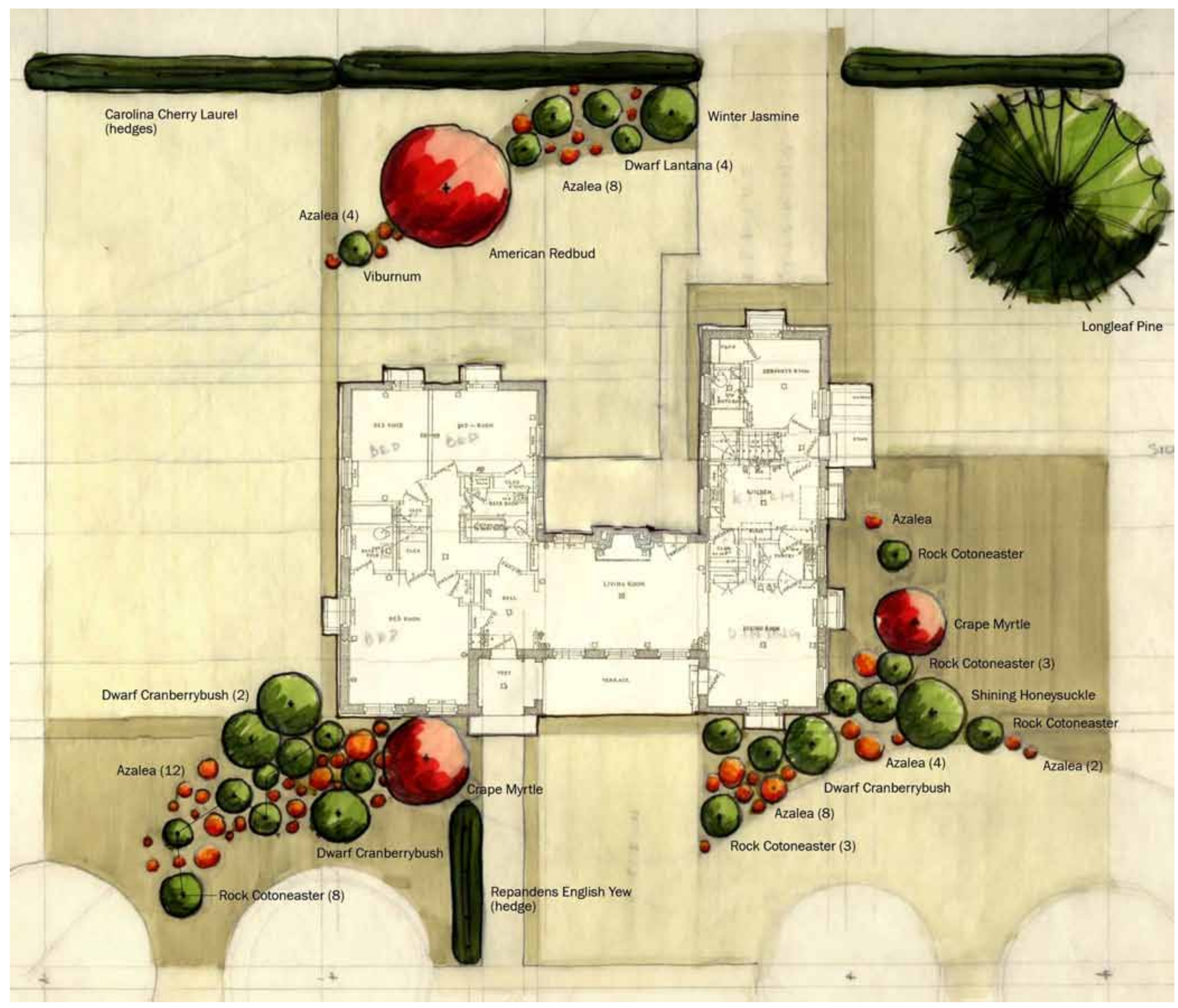

Figure 110. Plan view of proposed planting plan for ranch-style quarters in Normandy Heights neighborhood, 2010 (ERDC-CERL). 


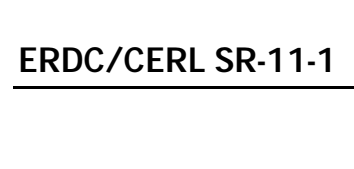




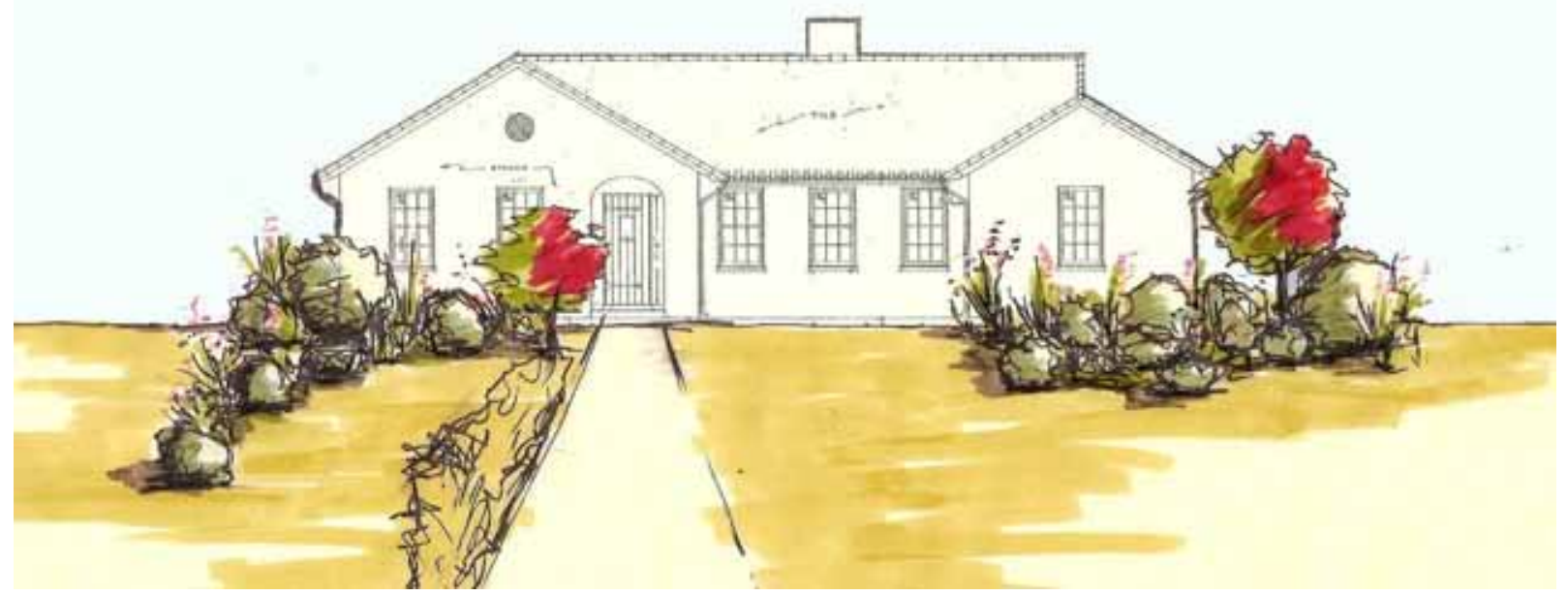

Figure 111. Elevation view of proposed planting plan for ranch-style quarters in Normandy Heights (ERDC-CERL). 


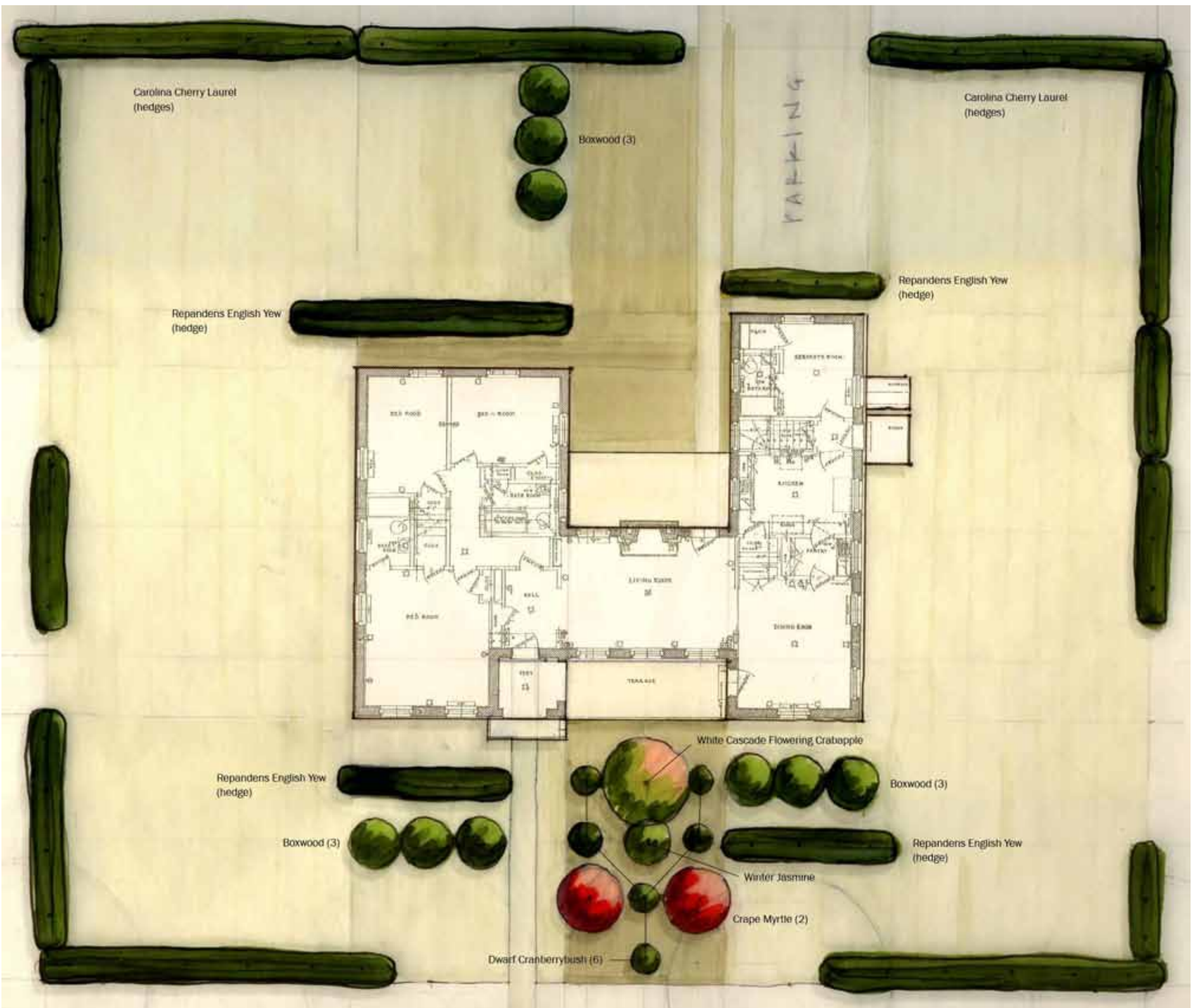

Figure 112. Plan view of proposed planting plan for ranch-style quarters in Normandy Heights neighborhood, 2010 (ERDC-CERL). 


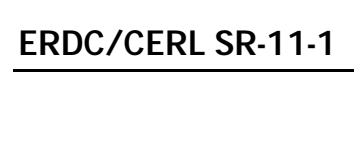




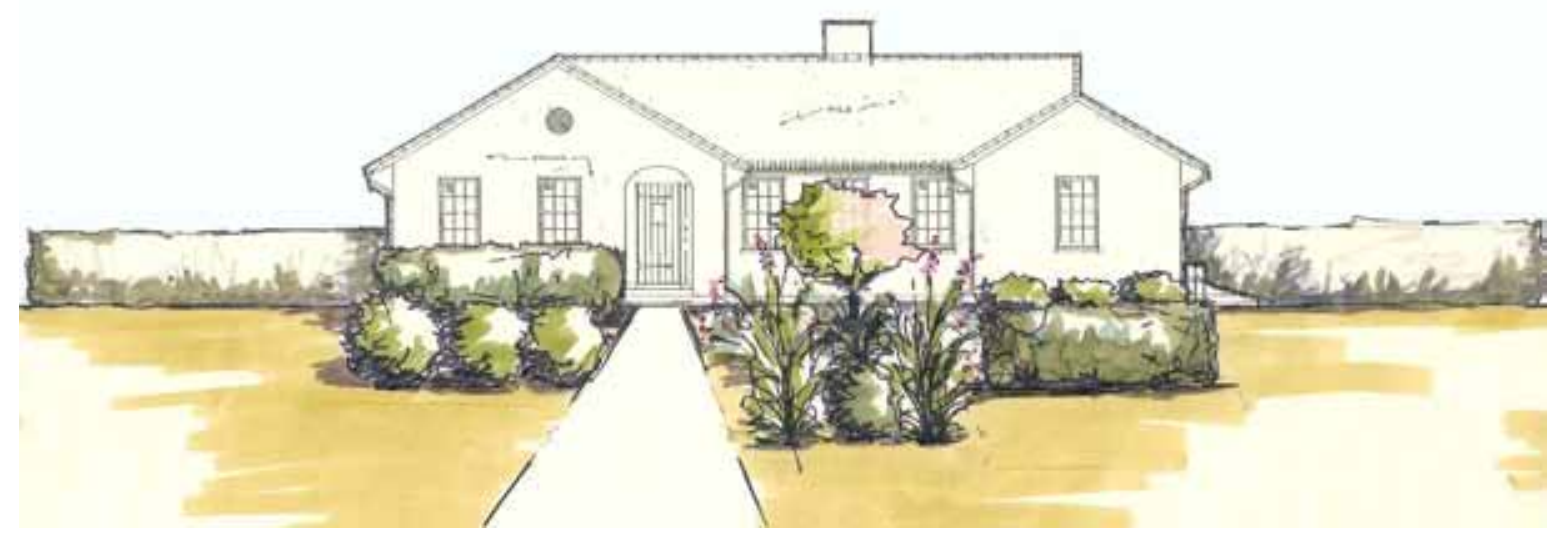

Figure 113. Elevation view of proposed planting plan for ranch-style quarters in Normandy Heights (ERDC-CERL).

\section{Bastogne Gables}

Bastogne Gables was constructed between 1928 and 1939. The neighborhood was built as family housing for Non-Commissioned Officers and consists of 96 bungalows organized around Humphrey Plaza, a central, rectangular park. The neighborhood has a system of primary streets and secondary, back alleys where the houses' detached garages are located. Bastogne Gables still serves as NCO housing, retaining its original layout and organization.

Humphrey Plaza

Humphrey Plaza is the open space and park in the Bastogne Gables neighborhood. The plaza was integrated into the neighborhood to promote the healthy lifestyles of the residents (Figure 114). 


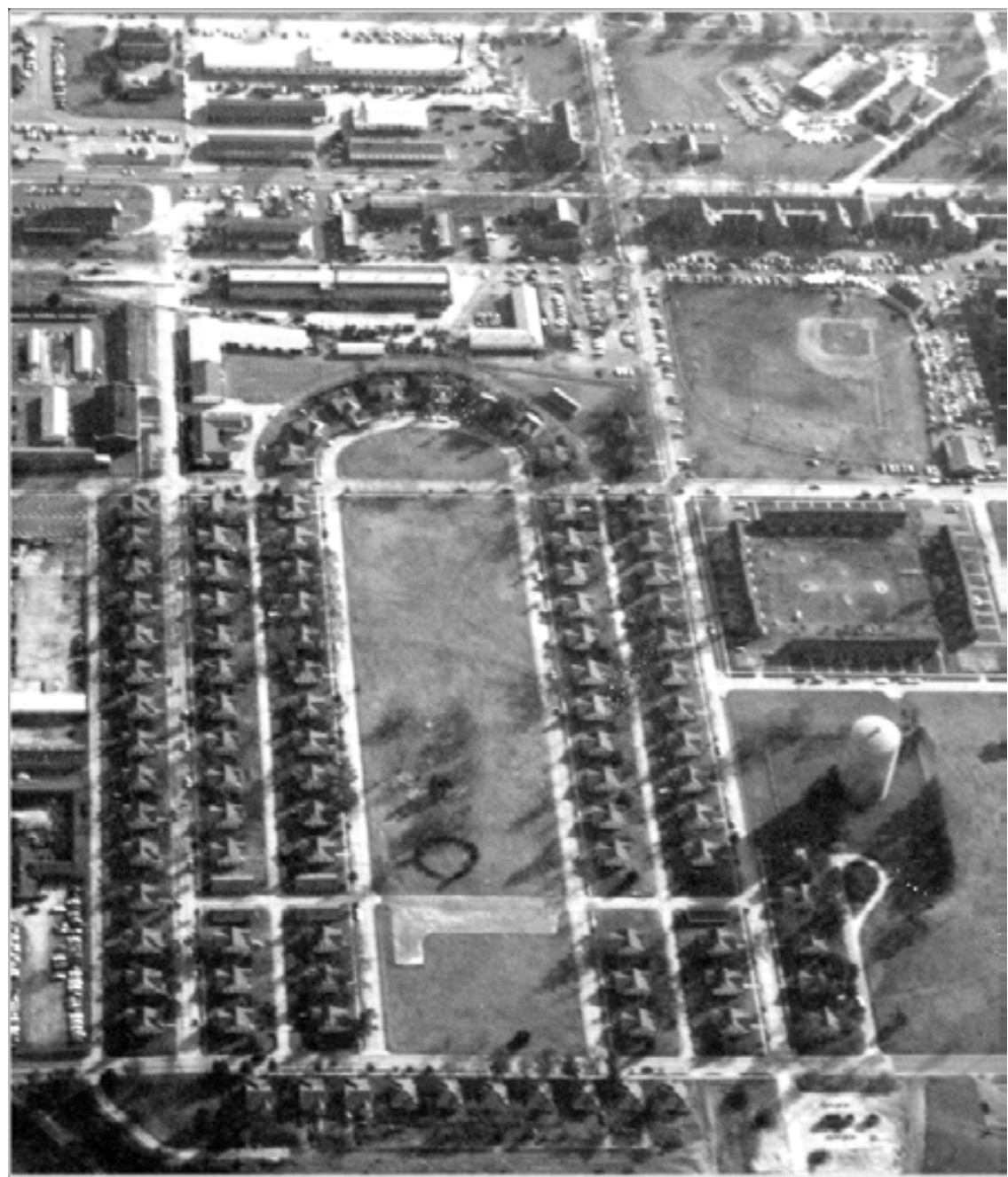

Figure 114. Aerial, looking south, of Bastogne Gables and Humphrey Plaza, 1968 (Fort Bragg Cultural Resources).

Historic Characteristics

- The neighborhood is organized around a central open space with rows of regularly spaced houses on all sides. The neighborhood was built as family housing for Non-Commissioned Officers (Figure 115).

- The network of streets and back alleys combined with street trees emphasizes the cantonment's park-like setting.

- The architectural style of the houses is Spanish Eclectic, mirroring the Normandy Heights neighborhood. The houses are all one-story and have sitting porches in the front; detached garages are located in the alleys. 


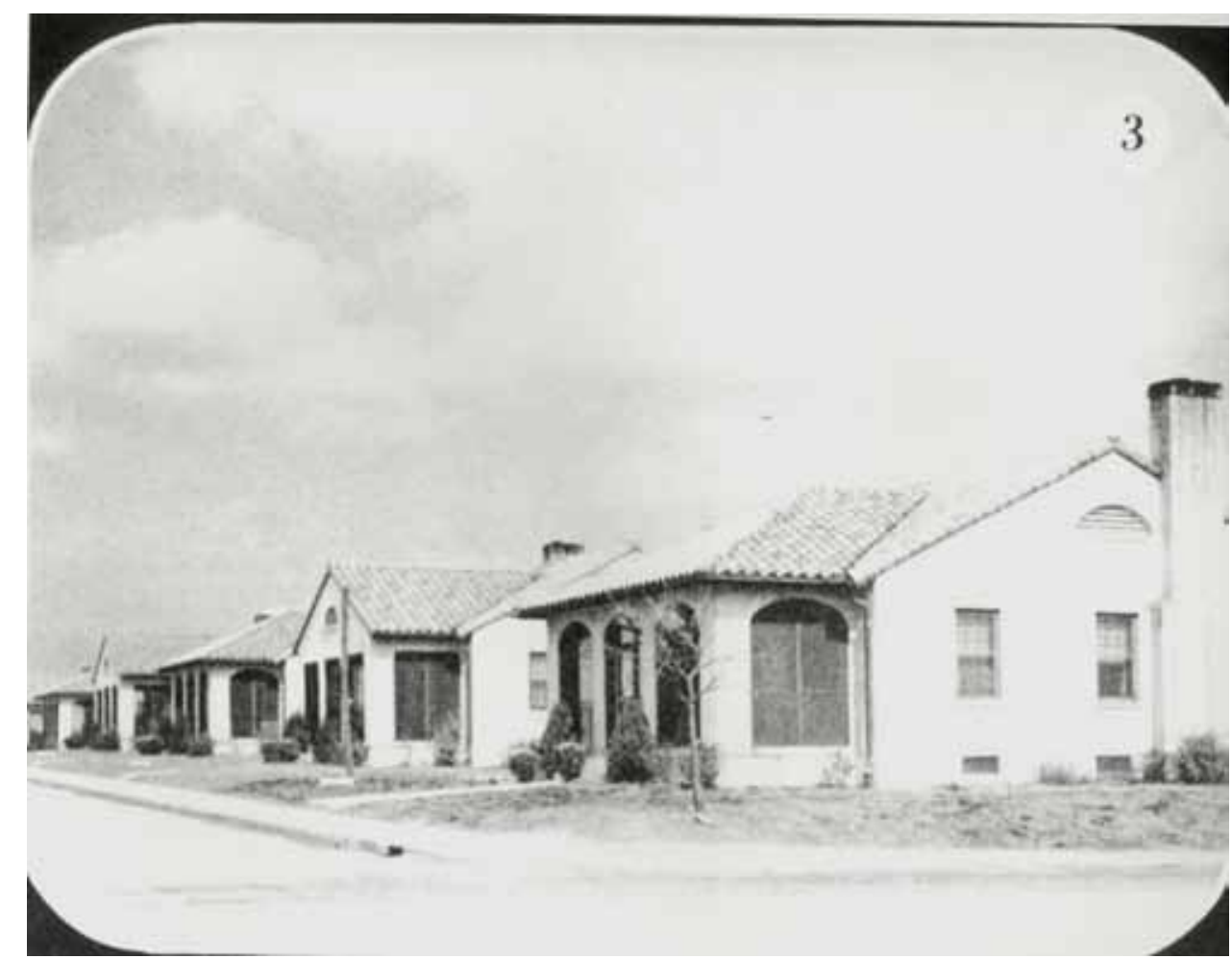

Figure 115. Non Commissioned Officers' Housing, Bastogne Gables, 1941 (Fort Bragg Cultural Resources).

\section{Existing Conditions}

Bastogne Gables retains much of its original layout with the symmetrical arrangement of houses around the central open space. The network of roads is still used and the houses are in good condition, although a few of the garages have been removed. Playground equipment and a basketball court have been added to the park and open space (Figure 116).

The vegetation of the neighborhood is either sparse or overgrown and unkempt. The yards are turf grass, but there are large areas of bare sandy soil. The street trees in the neighborhood are planted along the northern edge and there is no hierarchy of plantings to delineate the streets from the alleys (Figure 117). Landscaping around the houses is minimal and mainly consists of small evergreen shrubs around the foundations (Figure 118). Humphrey Plaza remains an open space in the neighborhood. The addition of playground equipment and a basketball court have not detracted from the open vistas. 


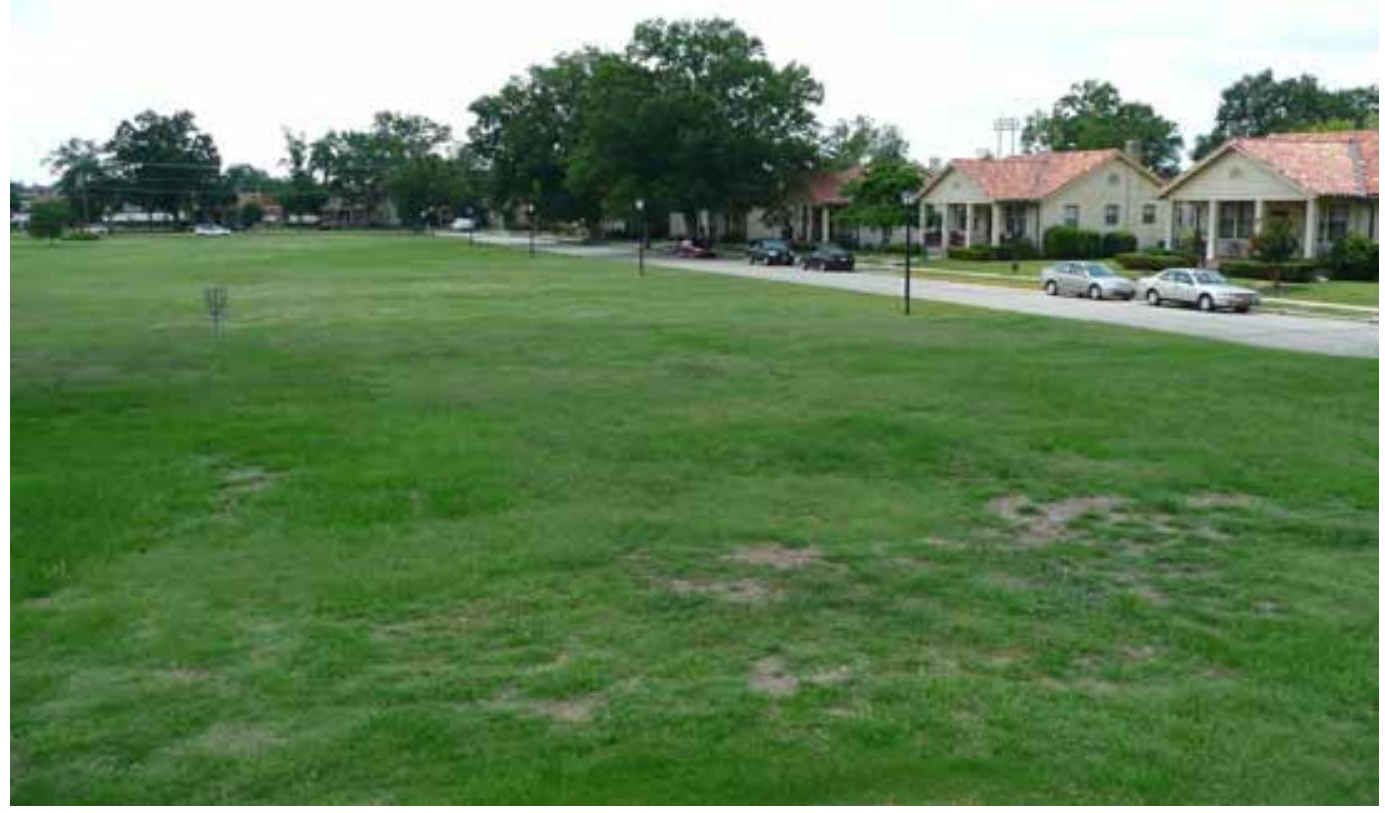

Figure 116. Bastogne Gables houses and open space, 2009 (ERDC-CERL).

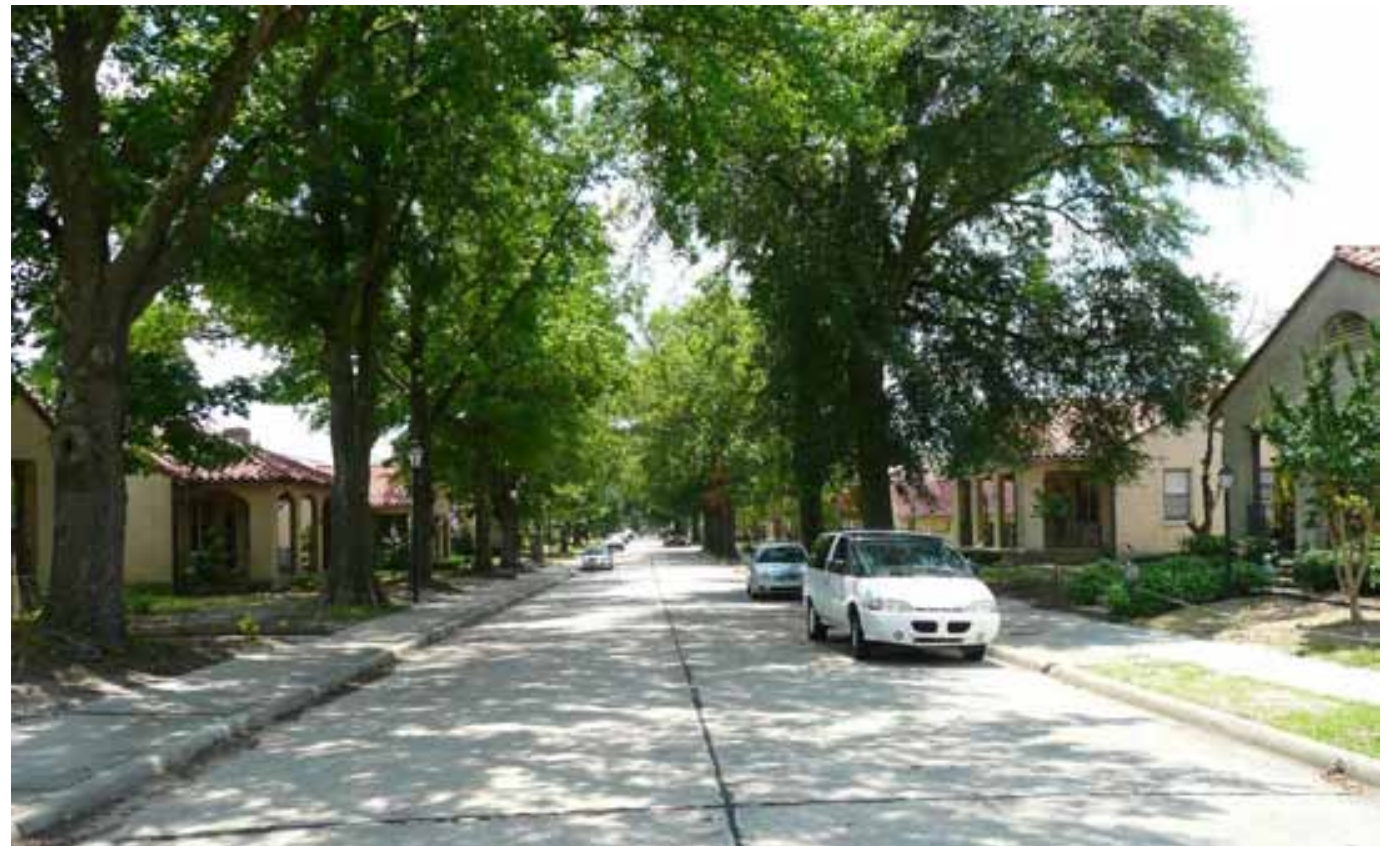

Figure 117. Bastogne Gables streetscape, 2009 (ERDC-CERL). 


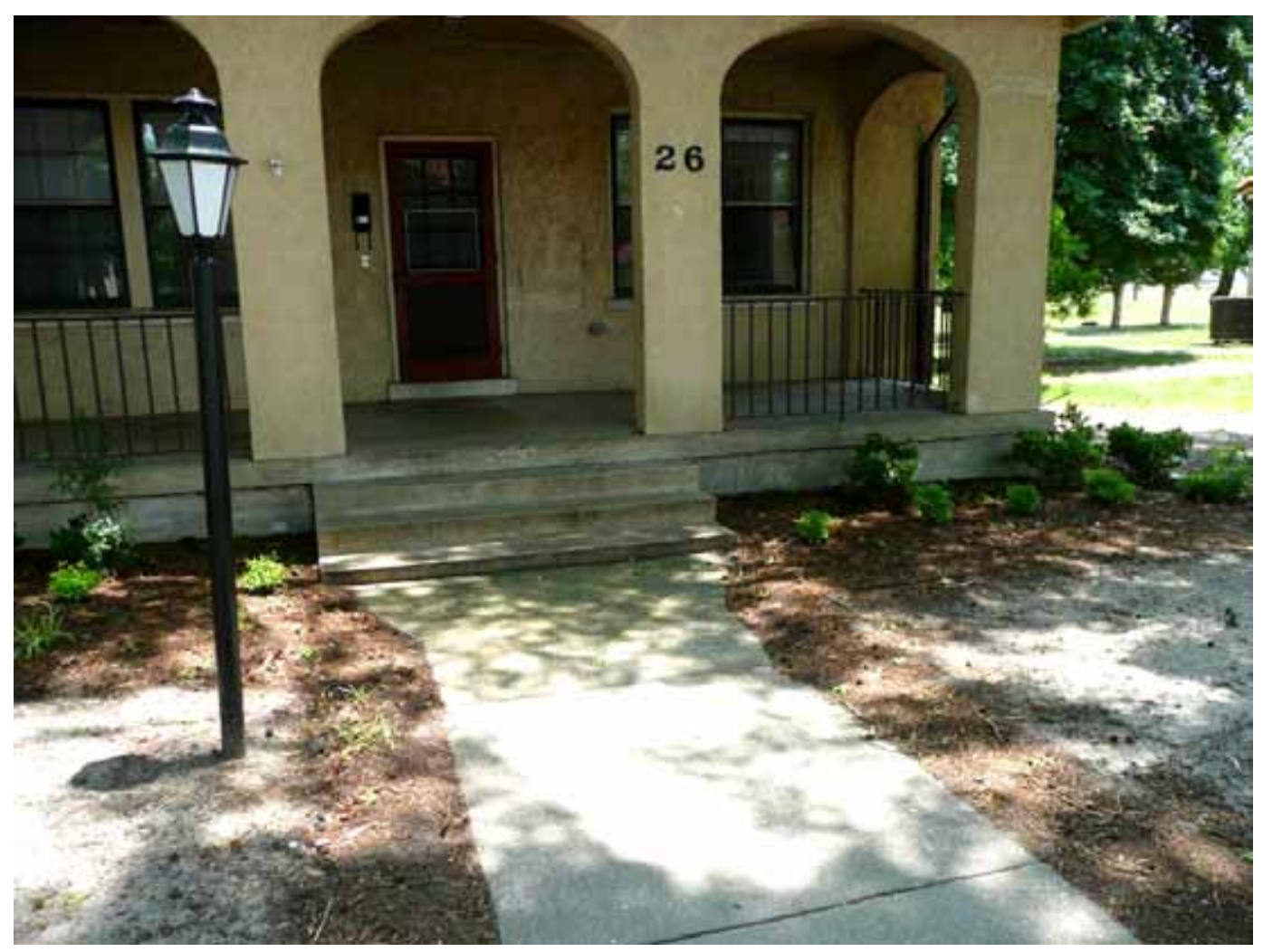

Figure 118. Bastogne Gables front plantings, 2009 (ERDC-CERL).

\section{Design Recommendations}

- The organization of the neighborhood should be maintained, including the hierarchy of streets and the housing organization.

- Humphrey Plaza should remain as an open space in Bastogne Gables.

- Appropriate shade trees could be added around play areas.

- Plant street trees along all main streets, the only exception is along Woodruff Street to retain the flow of the central park with the semicircle of houses to the south. See Appendix B for the 1933 standardized plans for planting street trees.

- Functional spaces, like the alleys, parking spaces, and backyards should be screened with vegetation.

- Plants should be planted far enough from the building to ensure their mature size will not damage the façade or foundation. The mature size of a plant should also be considered in regard to the scale of the house; larger houses can accept larger plants, while smaller houses are overwhelmed by out of scale vegetation.

- Vegetation should be selected that requires minimal maintenance. When possible choose varieties native to the region. Groundcovers should be used to control weeds under larger plants (Appendix C). 
Figures 119-122 show examples of possible planting designs for the varying house types in the Bastogne Gables neighborhood. The 2010 proposed planting diagrams are based on the Army's 1933 standardized residential planting plans. Although the proposed plans are based on the 1933 planting plans, the new examples incorporate the design recommendations for the Bastogne Gables neighborhood outlined in this report. The proposed plans are merely guidelines illustrating possible, historically grounded planting solutions for the residences. The 2010 plans should be consulted if landscaping is to be undertaken; then the designs can guide plant choices and placement. Furthermore, when implementing landscaping changes, it is of primary importance to consider the continuity of the historic neighborhood as well as the context of the residence's existing vegetation. While continuity of style and plant material within each neighborhood is desired, it is not intended that every house be planted using the exact same plants and designs. Although order and uniformity are characteristics of military landscapes, diversified planting designs increase visual interest and highlight the residential area. 


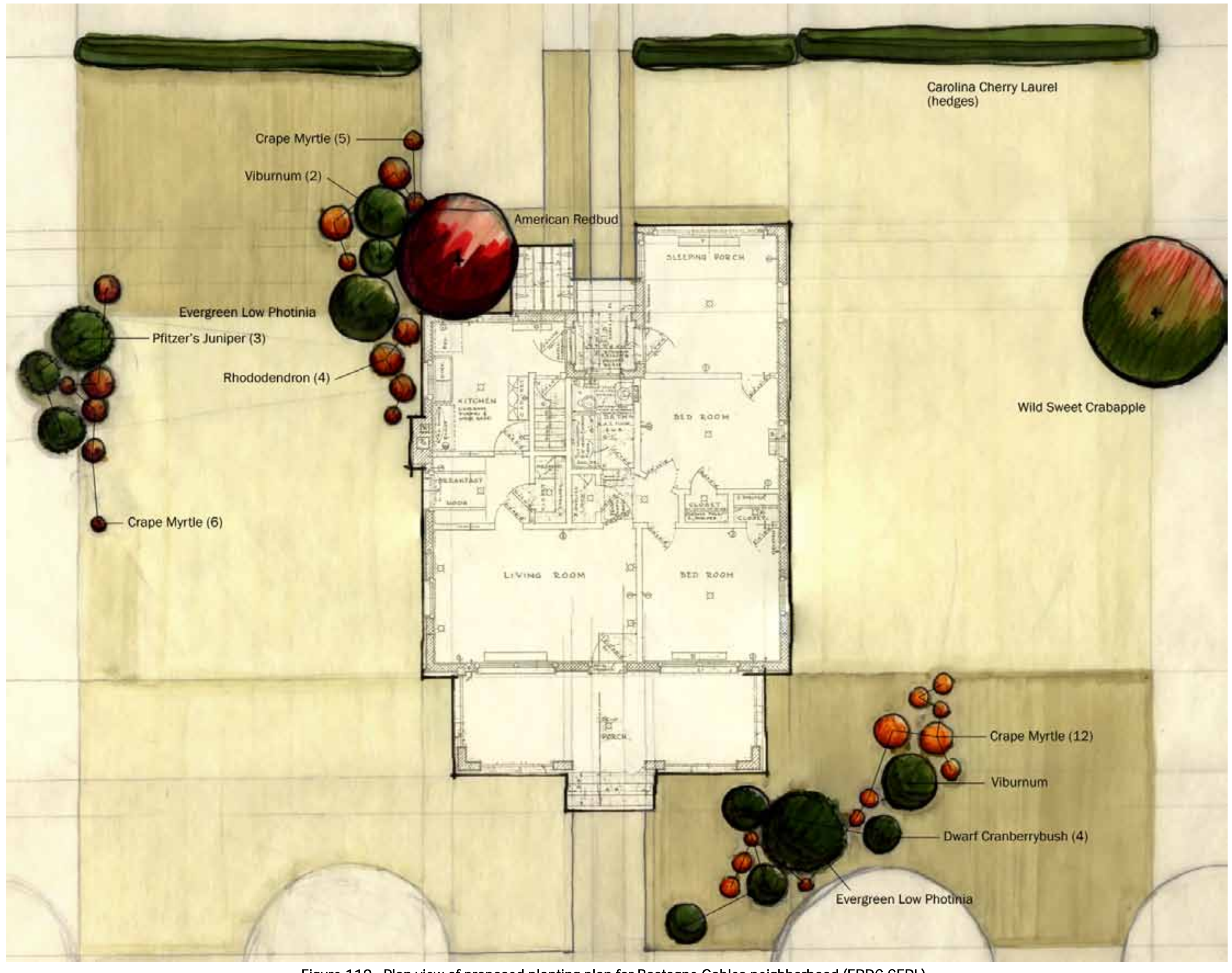

Figure 119. Plan view of proposed planting plan for Bastogne Gables neighborhood (ERDC-CERL). 



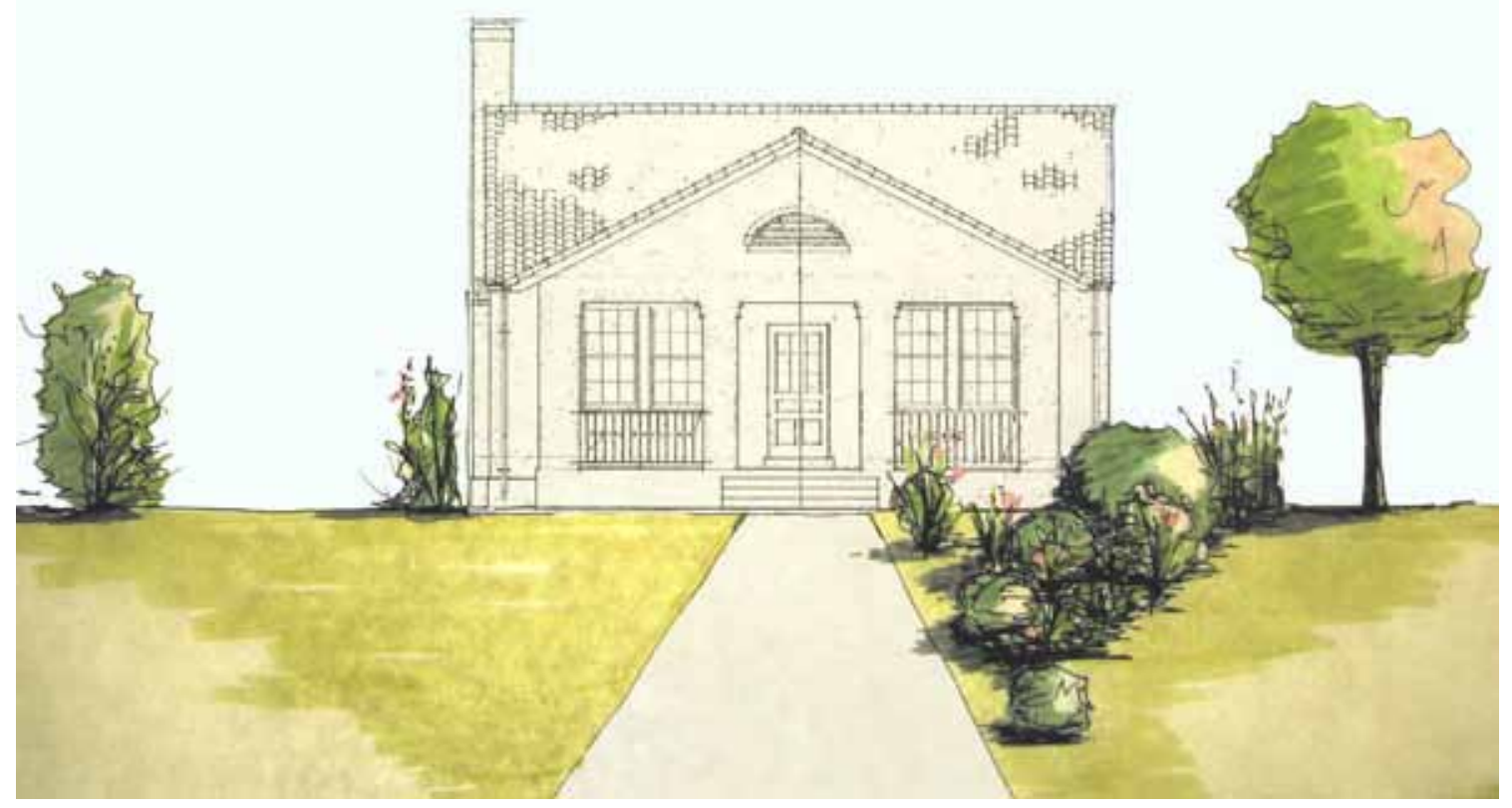

Figure 120. Elevation view of proposed planting for Bastogne Gables neighborhood (ERDC-CERL). 


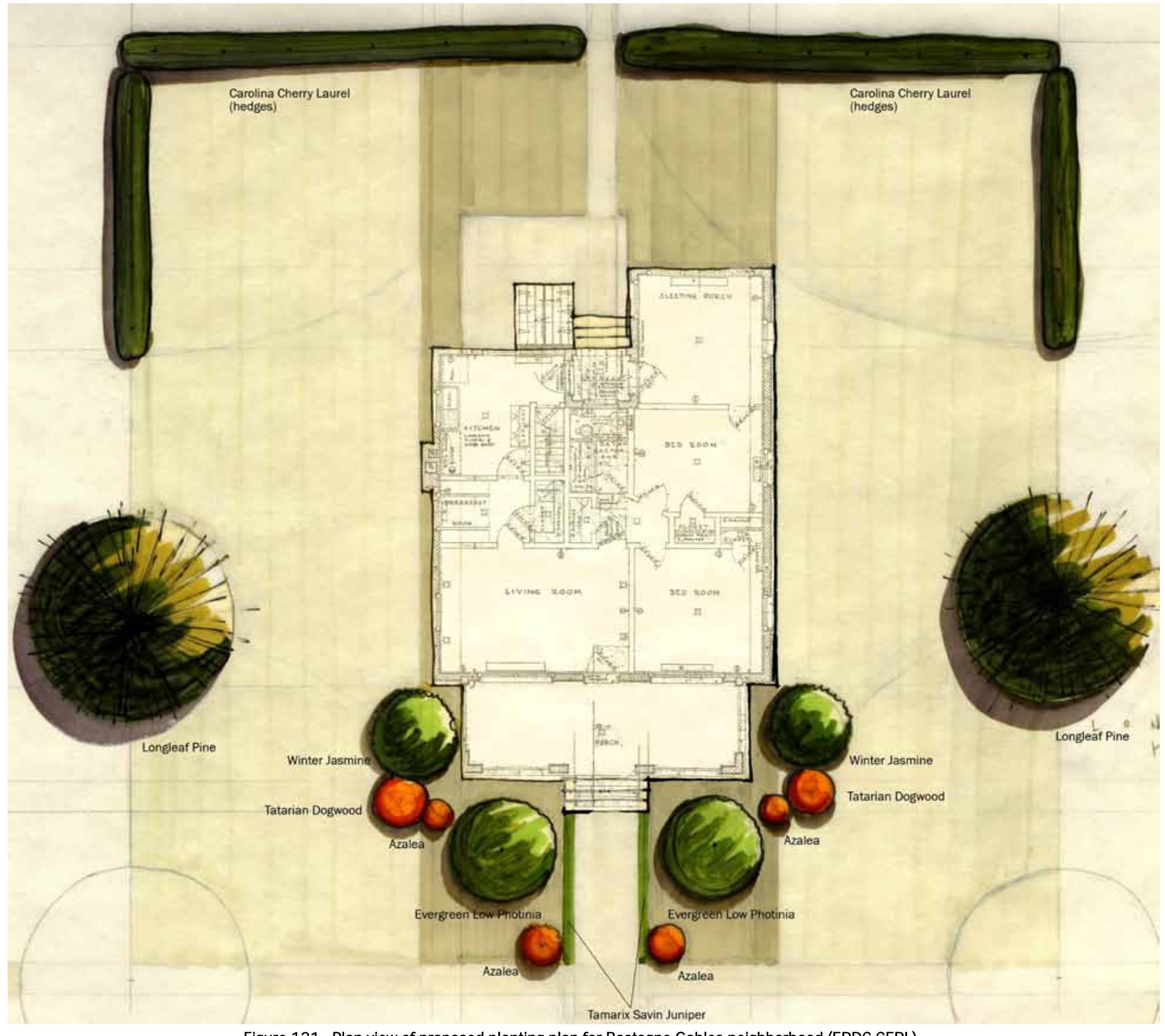

Figure 121. Plan view of proposed planting plan for Bastogne Gables neighborhood (ERDC-CERL). 



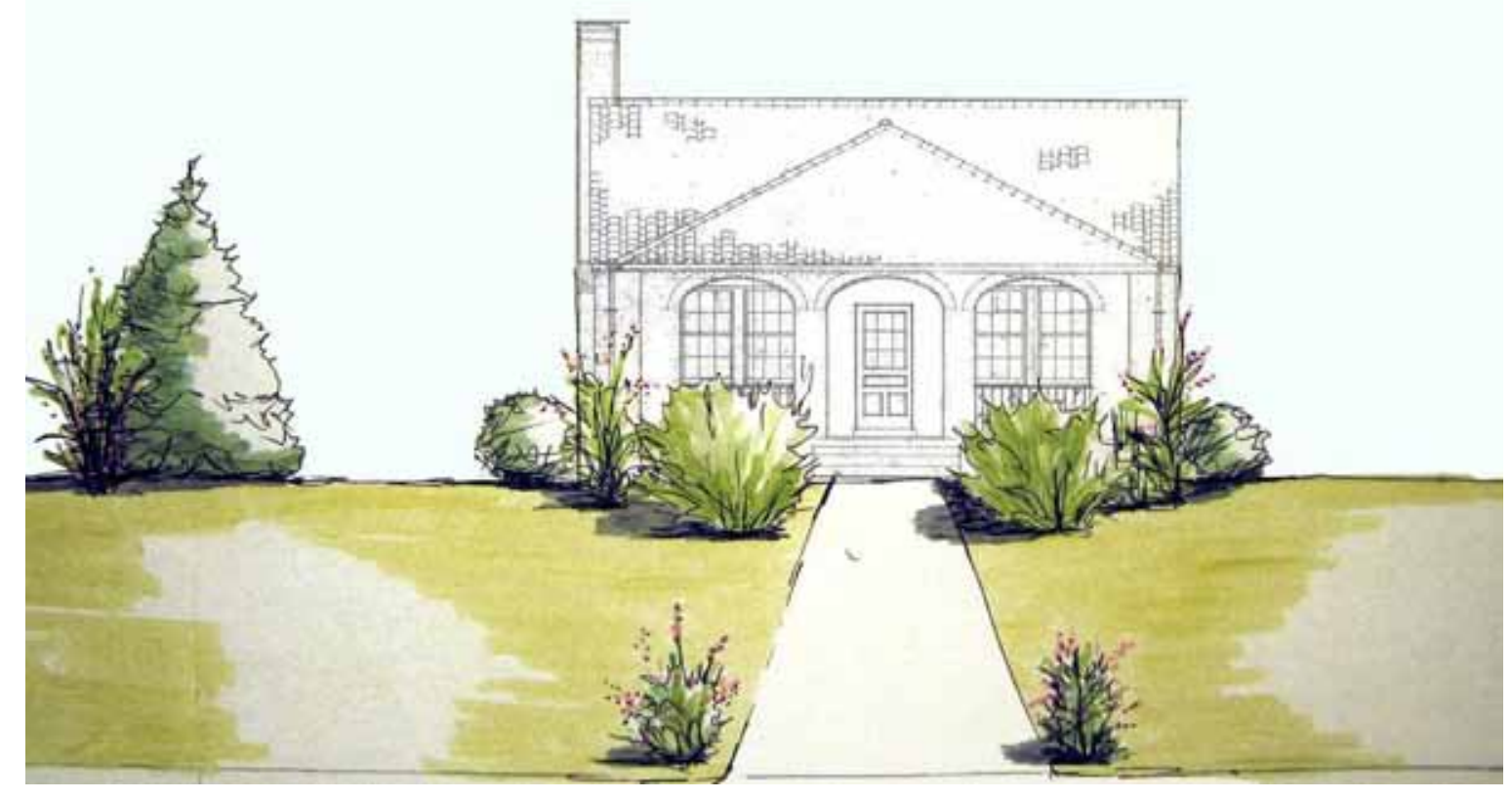

Figure 122. Elevation view of proposed plantings in Bastogne Gables neighborhood (ERDC-CERL). 


\section{Recreational Areas}

\section{Polo Field}

\section{Historic Characteristics}

- The polo field was an important recreational and open space within the original cantonment (Figure 123).

- The field has always been dedicated to recreational purposes.

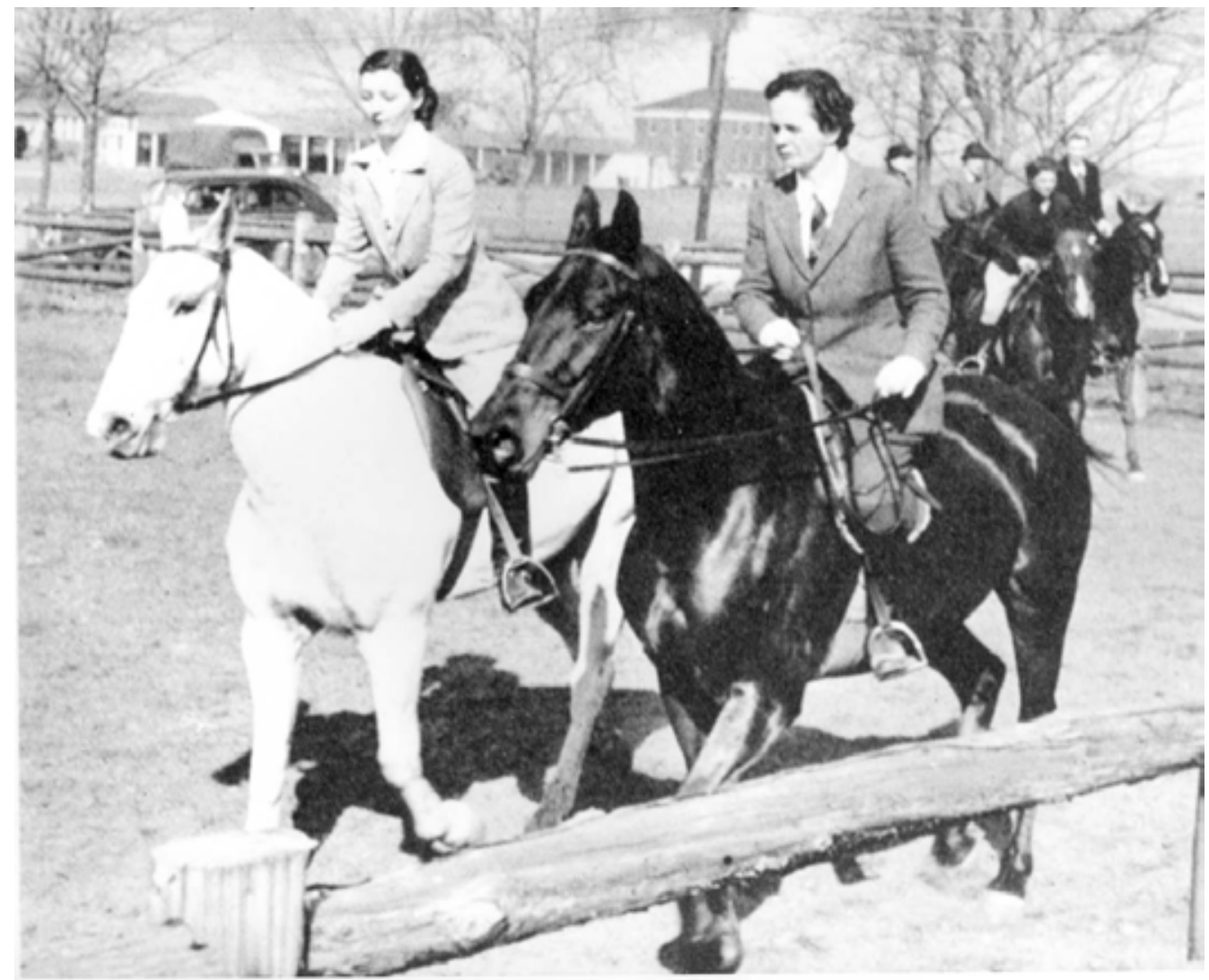

Figure 123. Polo field, 1941 (Fort Bragg Cultural Resources). 


\section{Existing Conditions}

The polo field remains in good condition and, while no longer used for polo, it is still a highly used recreational area (Figures 124-126). The field is bounded on the south and west sides by irregularly spaced trees. The perimeter of the field has an asphalt track and movable bleachers and goals are kept on the field for events. The grass has been worn down in areas where activities are concentrated.

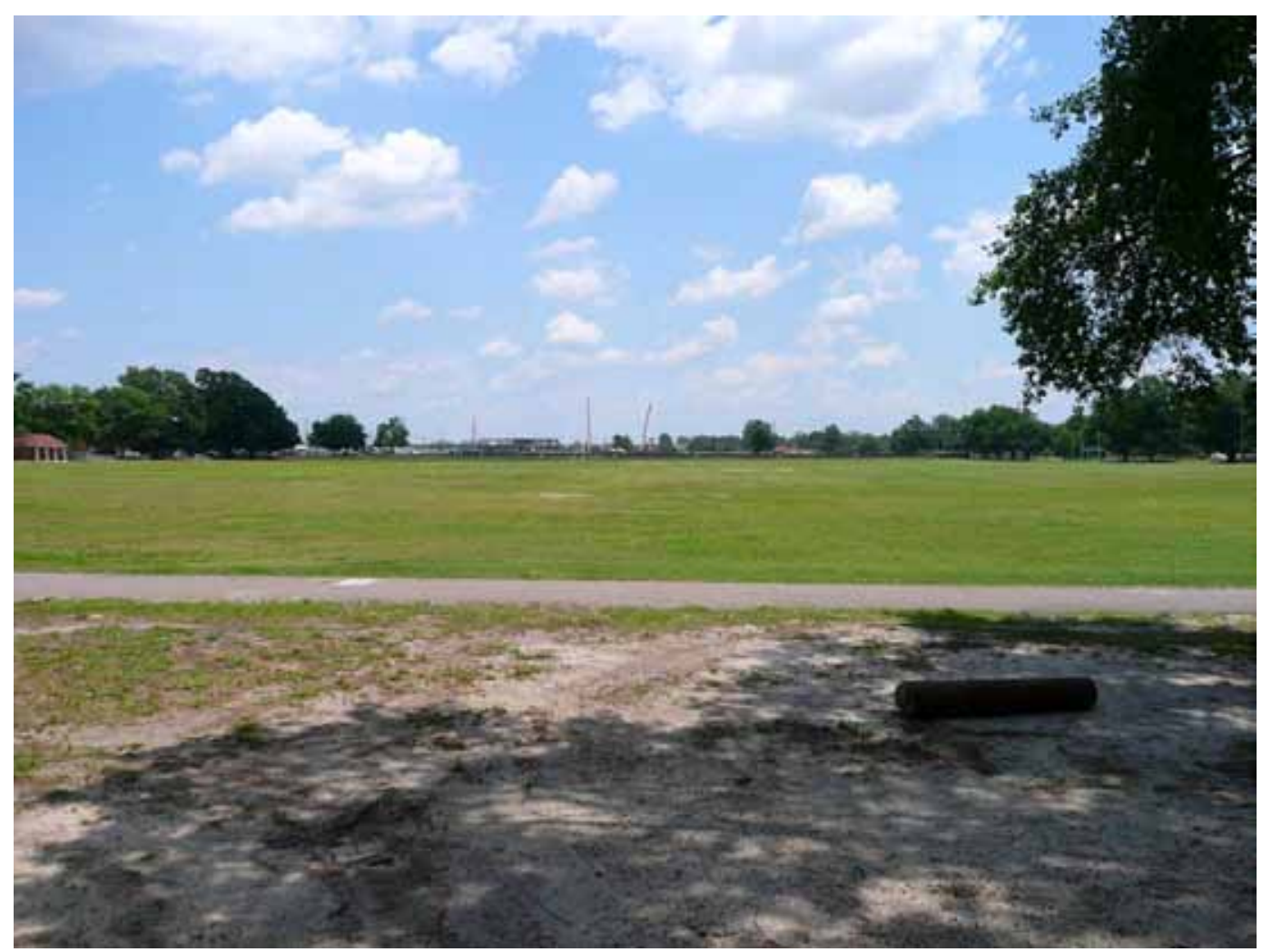

Figure 124. Looking west across the polo field, 2009 (ERDC-CERL). 


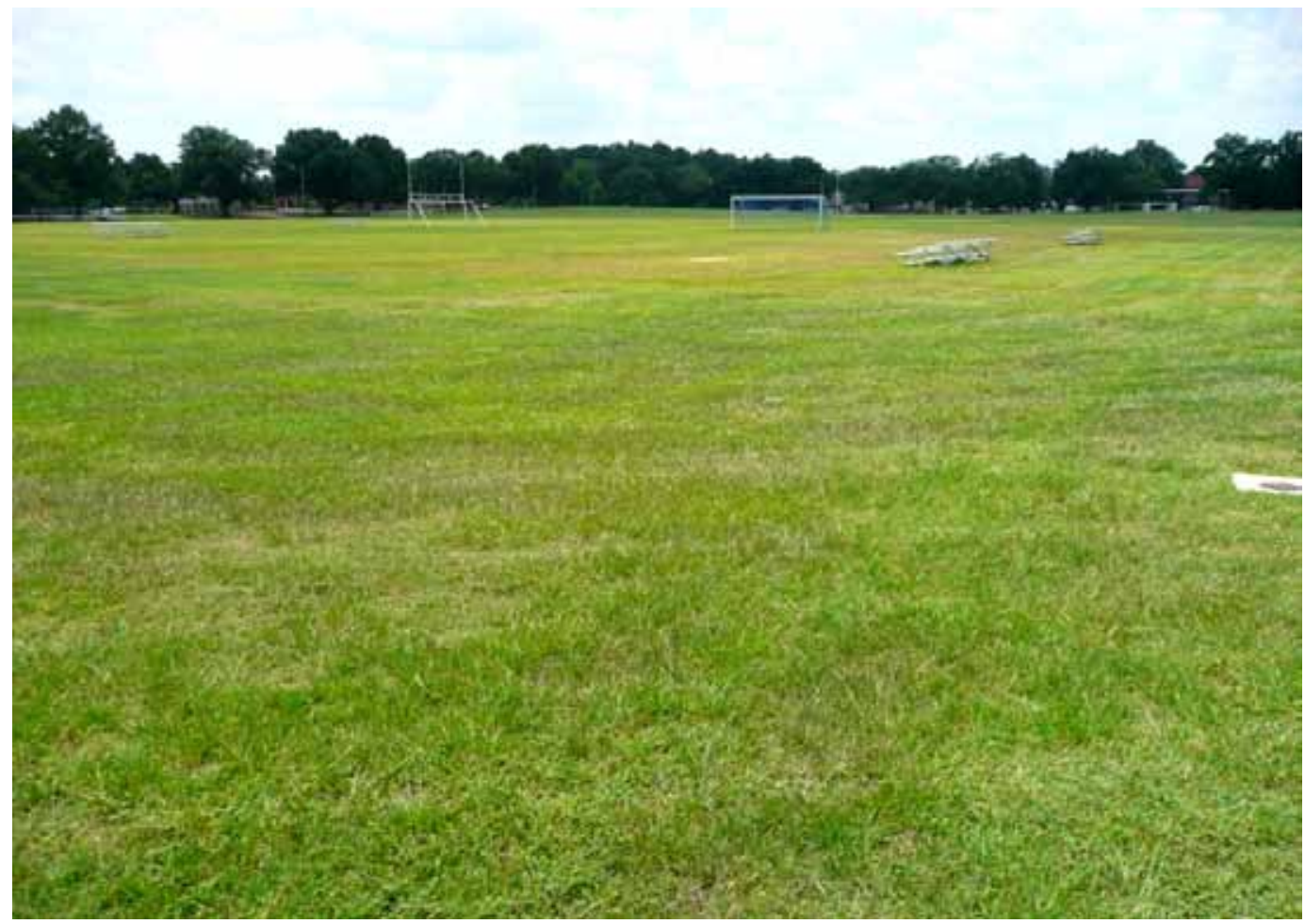

Figure 125. Polo field is now used for other sports, 2009 (ERDC-CERL).

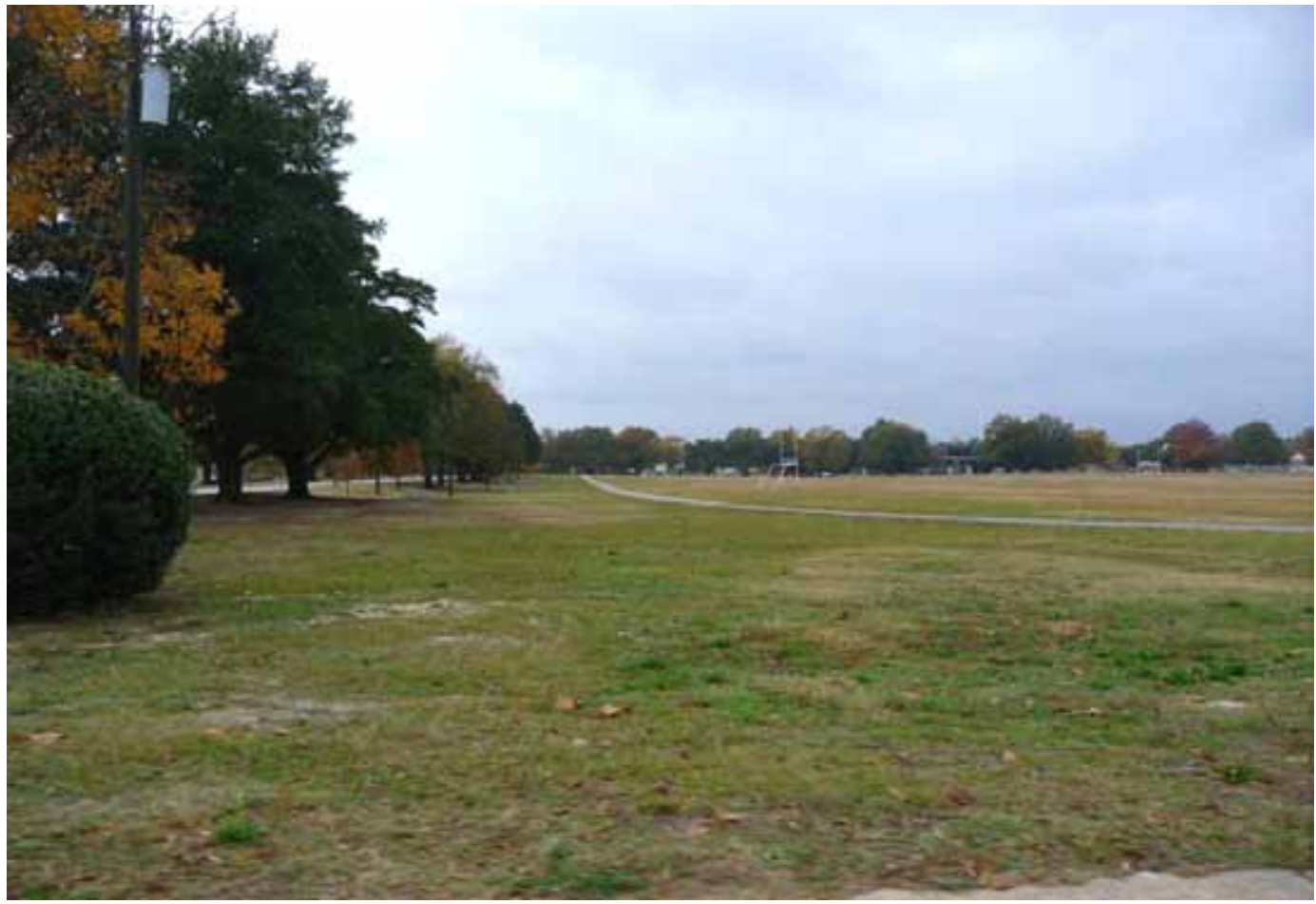

Figure 126. Polo field bounded with trees and showing the perimeter track, 2007 (ERDC-CERL). 


\section{Design Recommendations}

- The polo field should remain an open space within the historic district.

- While the field can accommodate multiple uses, its main purpose should remain as a recreational area in the cantonment. Therefore, the track and field should be maintained as such.

- Street trees should bound the entire field. More need to be added on the north and east sides. Ideally a variety of trees should be used, examples are, oak, pecan, and maple. See Appendix B for the 1933 standardized plan for street tree planting.

- Changes to the non-contributing area to the west of the polo field should consider the visual and spatial relationship of the polo field with the rest of the OPHD.*

\section{Ryder Golf Course}

Ryder Golf Course is located at the southeast corner of the historic district, east of the Normandy Heights neighborhood. Historically the "officers' golf course" at Fort Bragg, the course abuts the Fort Bragg Officers' Club. According to the Ryder Golf Course website, the course opened in 1930 with 27 holes (Fort Bragg Ryder Golf Course 2007). The Officers' Club was constructed after the course in 1939. First aerials of the course are dated 1933 (Figure 127), but Fayetteville Observer articles from 1924 mention a match between the Fort Bragg Officers' Team and the Carolina Country Club at Fort Bragg. The course is described as "sandy" (Fayetteville Observer, 1 March 1924). However, there is no mention of the location of the course or the number of holes. C.C. McCusion is credited as the course architect. ${ }^{\dagger}$ The Ryder club house was built in the 1950s. In the early 1990s, the course was opened to all eligible military users and renamed Ryder Golf Course.

\section{Historic Characteristics}

- Opened in 1930 with the original 27 holes.

- During the early 1960s nine holes were removed for new housing.

\footnotetext{
* The area bounded by Scott, Hamilton, Randolph, and Armistead streets.

+ Athough there are onlya few references to the golf course architect, there is some confusion over the spelling of his last name. Some sources list McCusion and others cite McCuiston. McCusion is the variation used on the Ryder Golf Course website and in a number of newspaper articles and so it is used in this report.
} 


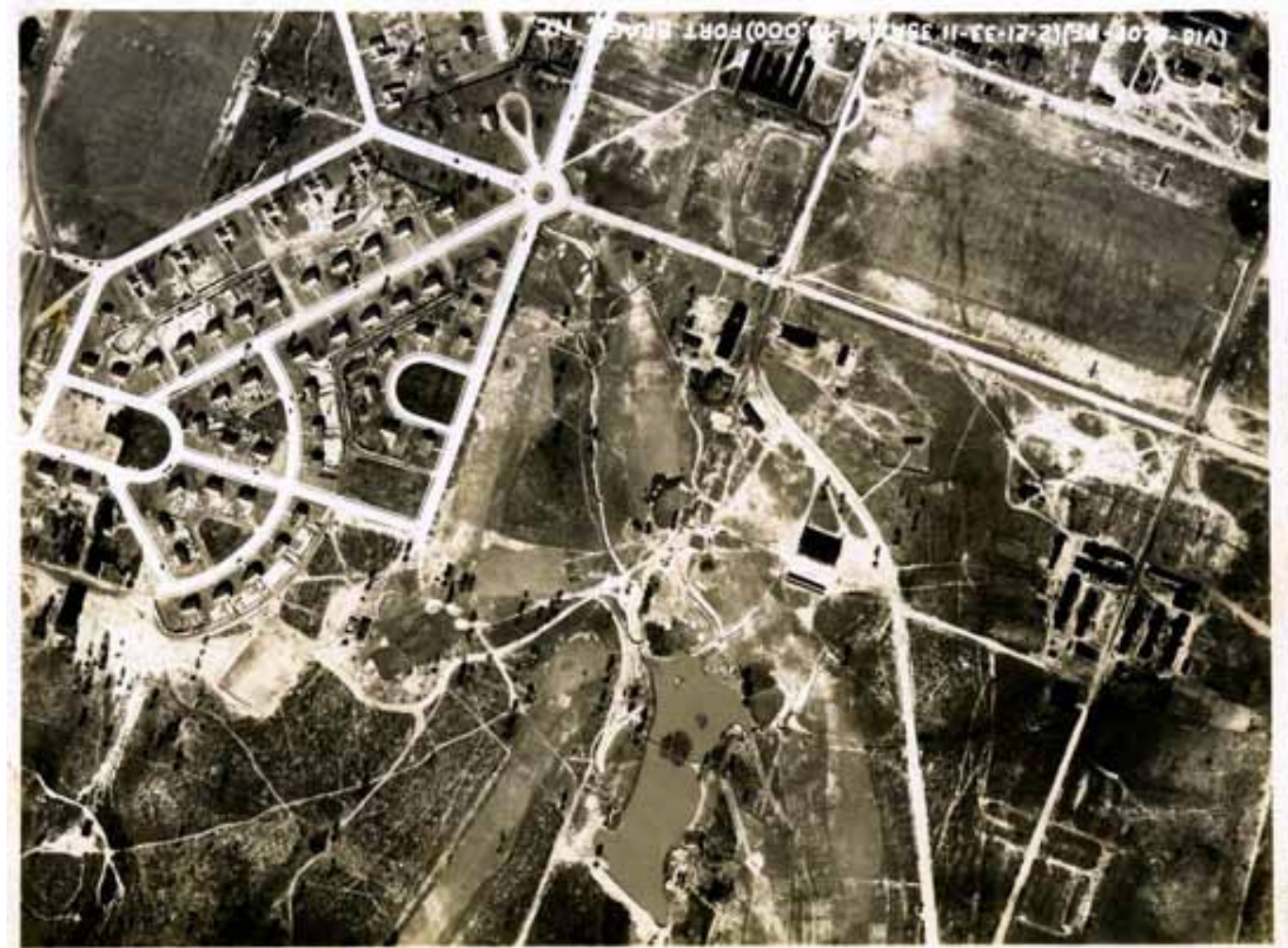

Figure 127. Aerial view of officers' golf course, 1933 (Fort Bragg Cultural Resources).

\section{Existing Conditions}

Ryder Golf Course is an 18-hole course. The course has several water features, the greens are small and rolling, and the fairways are tree lined and hilly (Figures 128-130). In 1999-2000 the course was renovated with a new irrigation system and bunkers.

A large parking lot is located west of the clubhouse and pool. Tennis courts were formerly located here, but have been converted to parking spaces. 


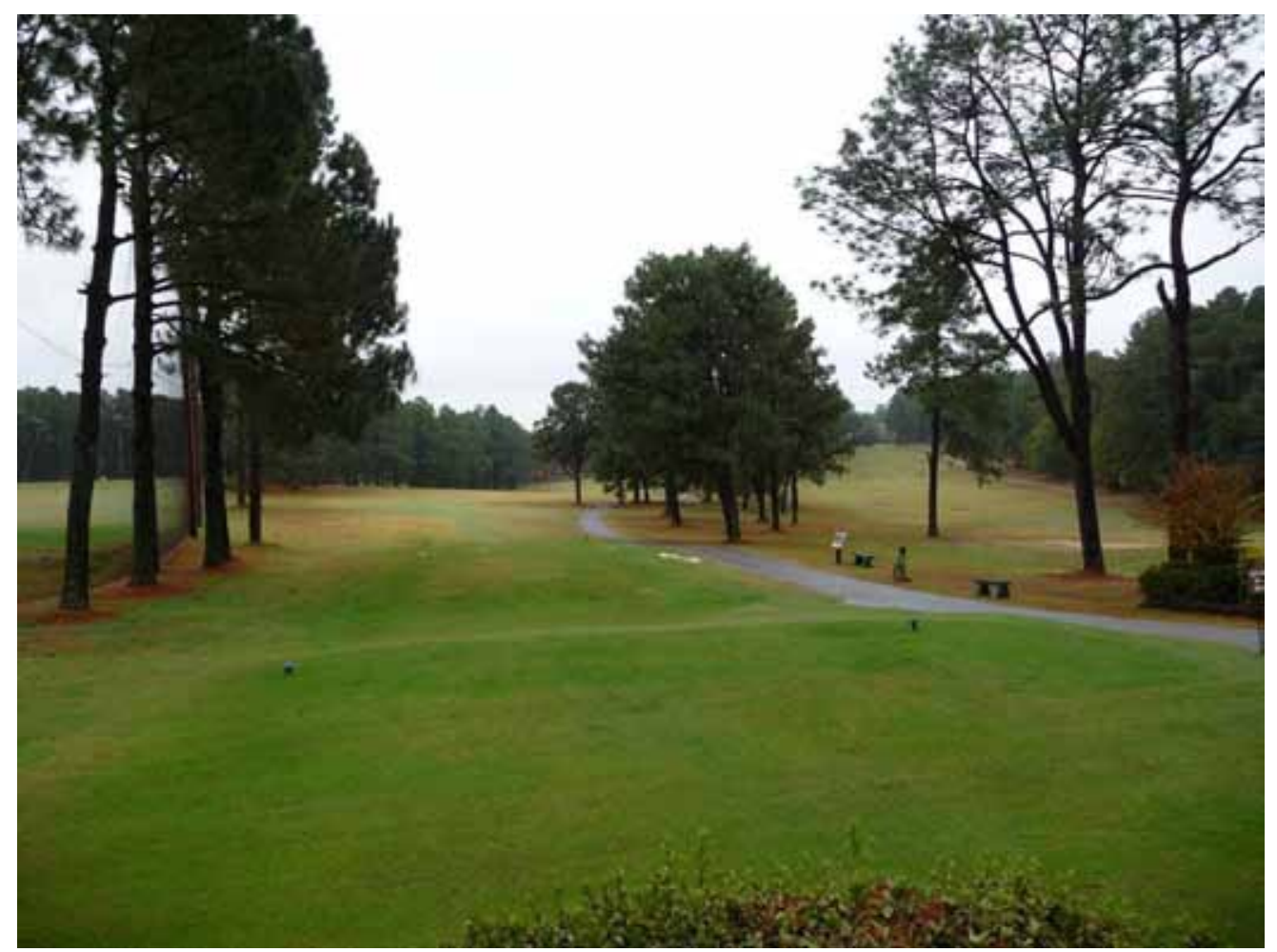

Figure 128. Ryder Golf Course 2007 (ERDC-CERL).

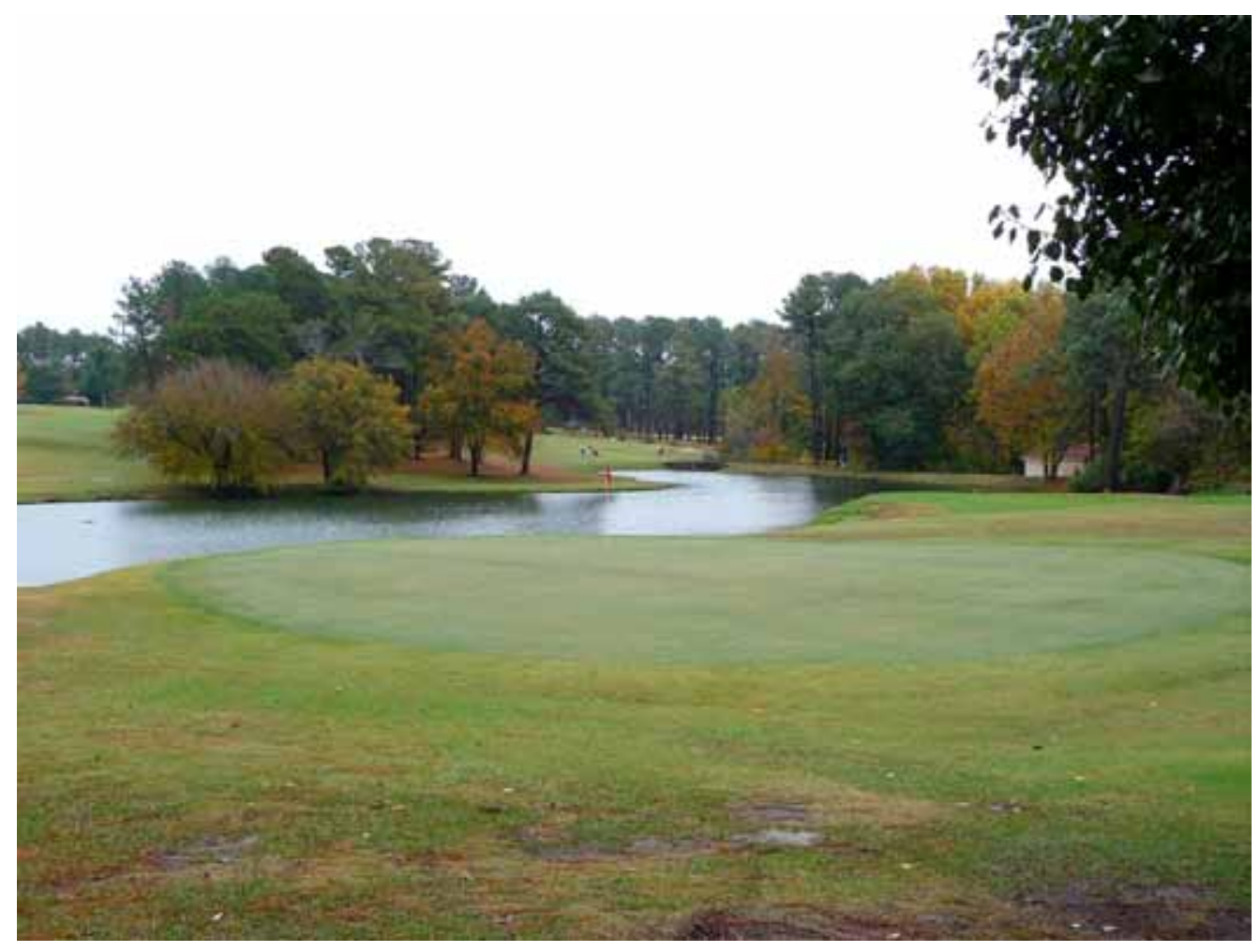

Figure 129. Ryder Golf Course, 2007 (ERDC-CERL). 


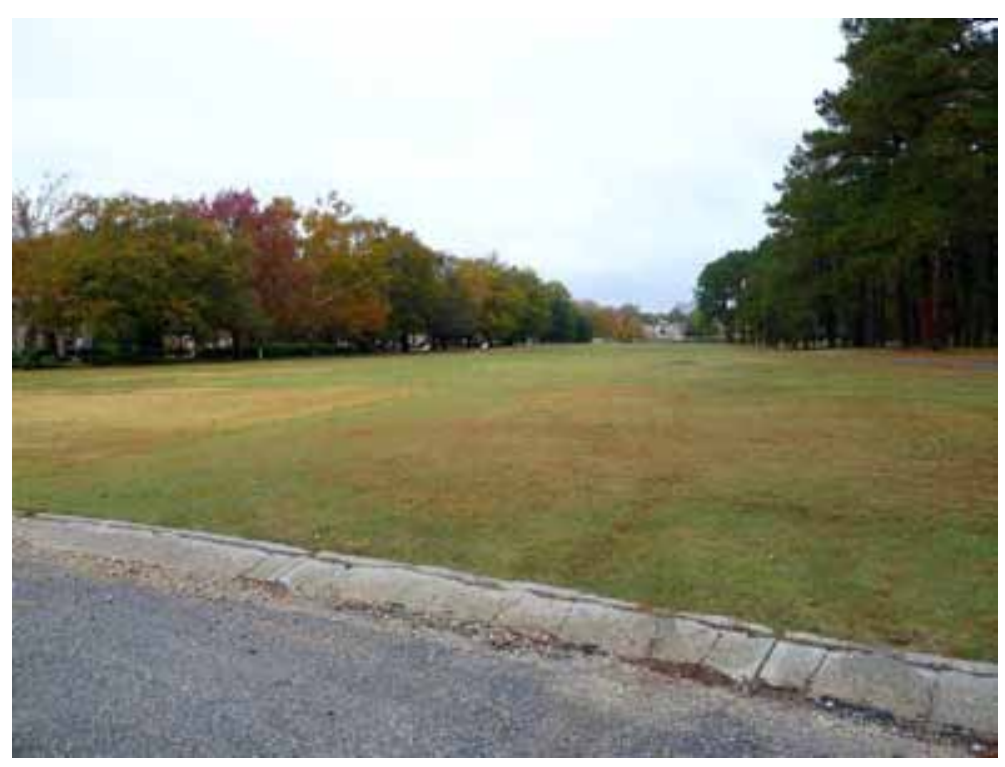

Figure 130. Normandy Heights neighborhood from Ryder Golf Course, 2007 (ERDC-CERL).

\section{Design Recommendations}

- Ryder Golf Course is an important recreational area within the historic district and is a significant open space in the installation.

- The golf course and Fort Bragg Officers' Club are historically associated and care should be taken to preserve this relationship.

- The parking area west of the clubhouse and pool should not obstruct the original recreational intention of the area.

\section{Baseball Fields}

\section{Historic Characteristics}

- The baseball fields were important recreational and open spaces in the barracks complex.

- Bowley Field, to the east, was named for General Albert J. Bowley.

- Ruth Field, to the west, was supposedly named for Babe Ruth because of his connections with Fayetteville, NC.

- The fields have always been dedicated to recreational purposes.

\section{Existing Conditions}

The baseball fields remain in good condition and are still recreational areas in the OPHD (Figures 131- 135). The fields have dugouts, fences, and lighting, but they are currently surrounded by parking lots. The grass has been worn down where activities are concentrated. 


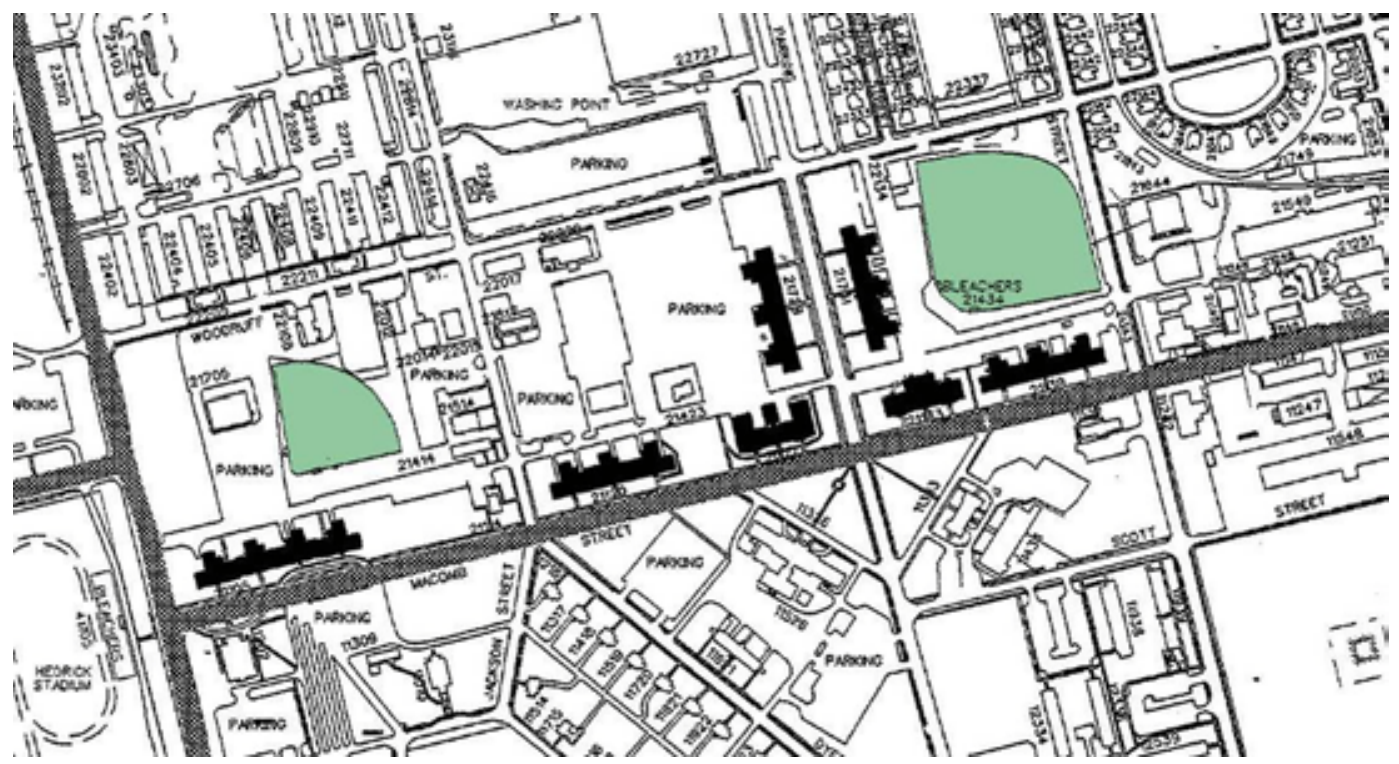

Figure 131. Map showing baseball fields north of barracks, 1993 (Fort Bragg Cultural Resources).

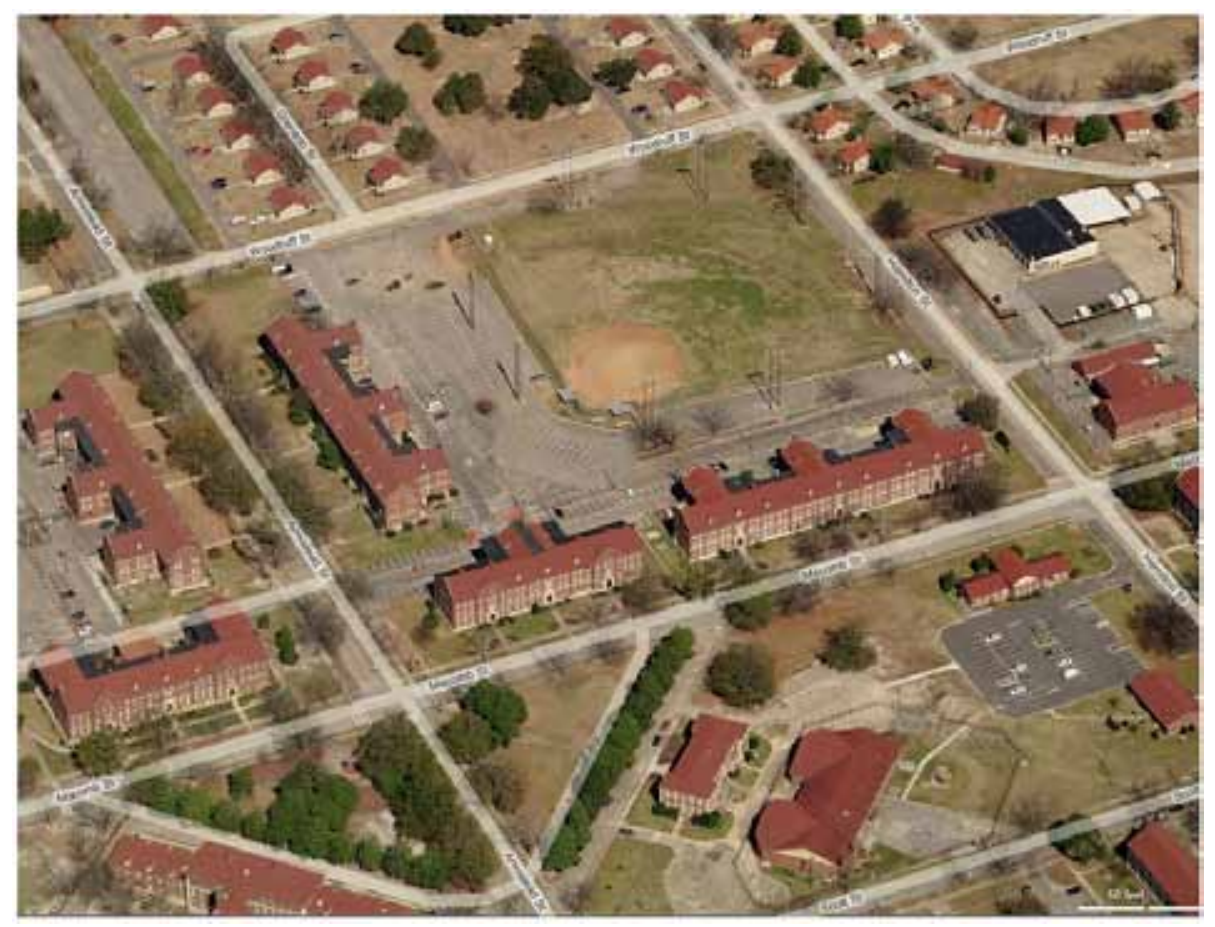

Figure 132. Aerial view of Bowley baseball field north of barracks, southwest of Bastogne Gables, 2010 (Pictometry Intemational Corporation). 


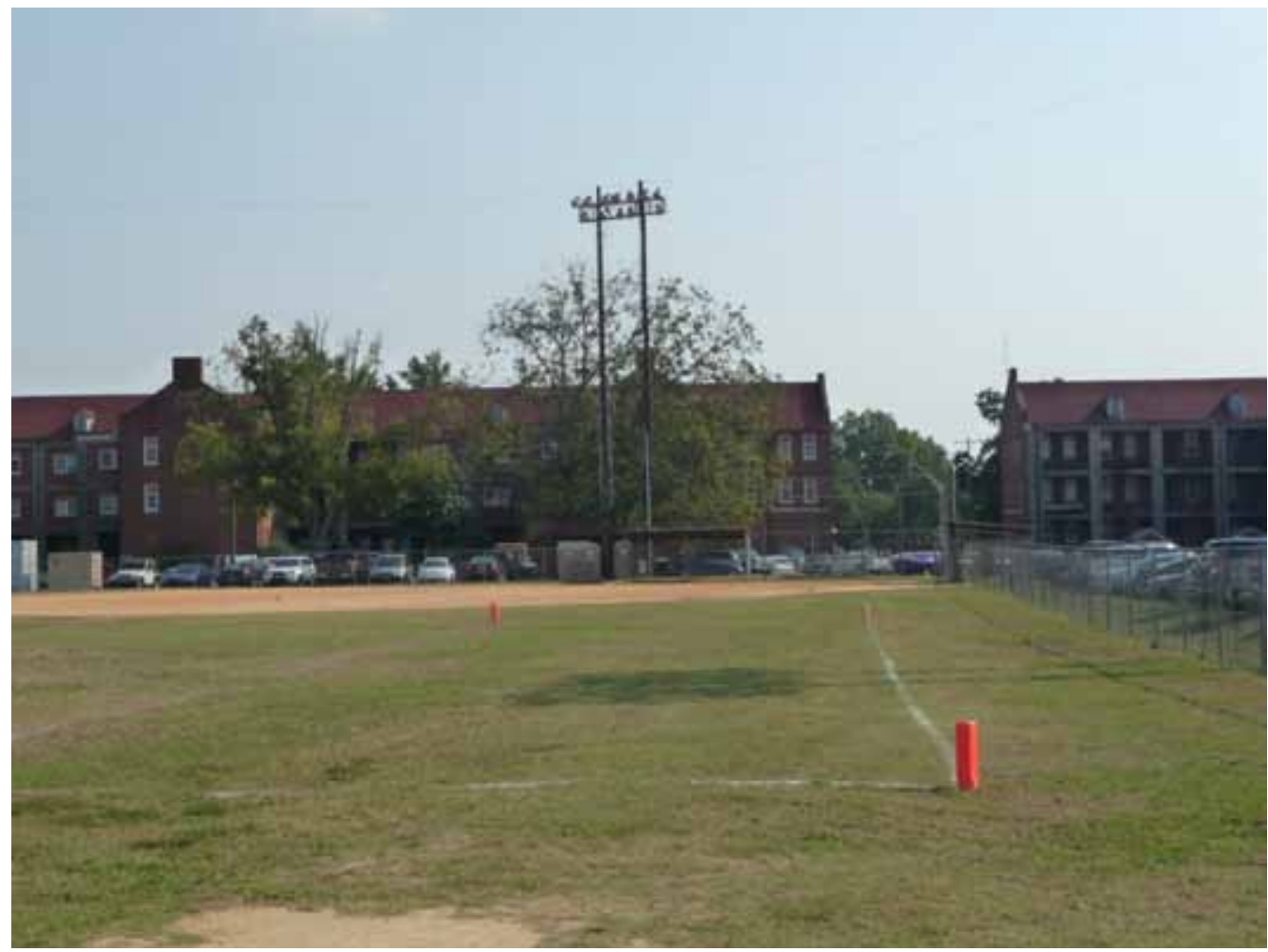

Figure 133. Bowley Field, 2010 (ERDC-CERL).

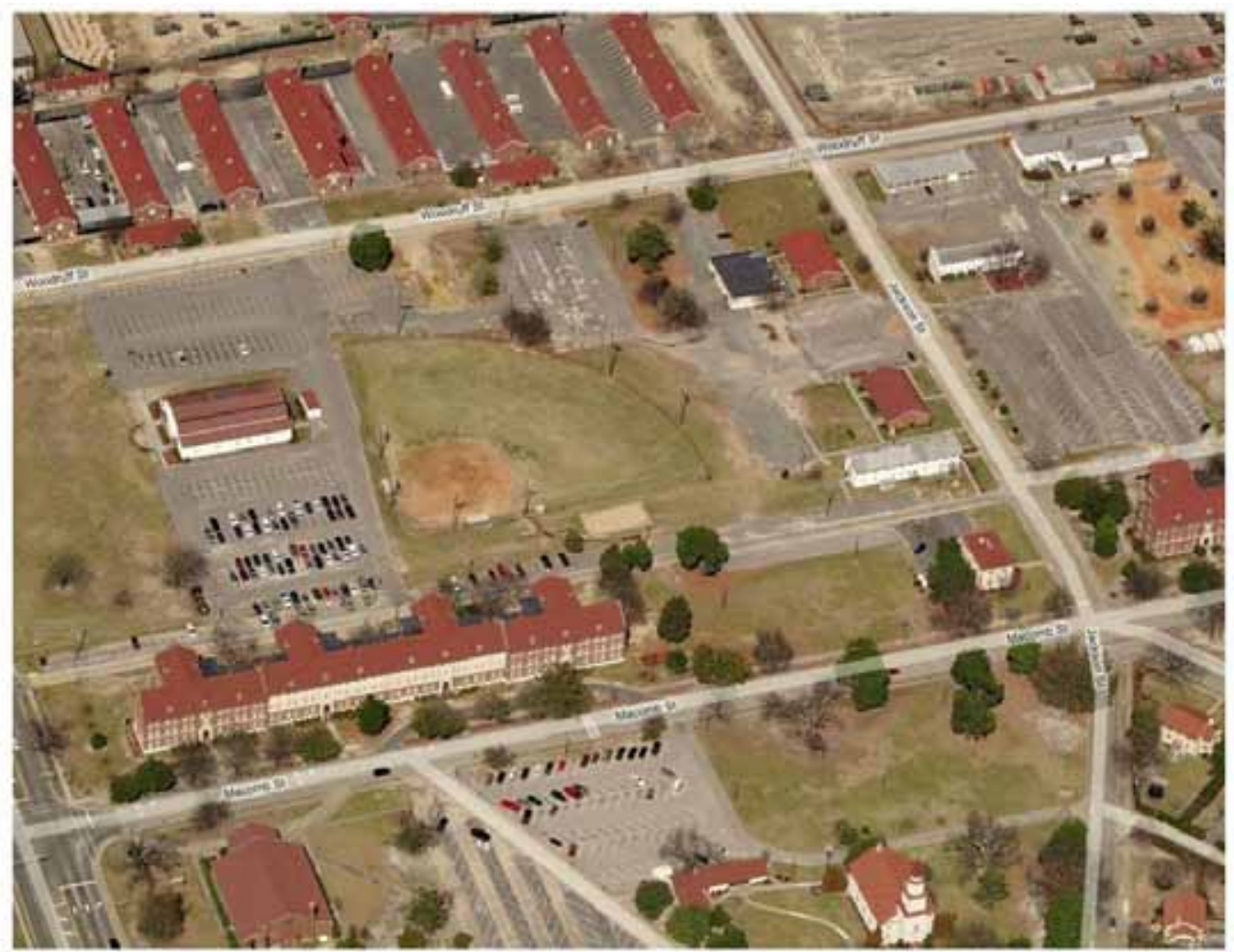

Figure 134. Aerial view of Ruth baseball field north of barracks south of mule bams, 2010 (Pictometry Intemational Corporation). 


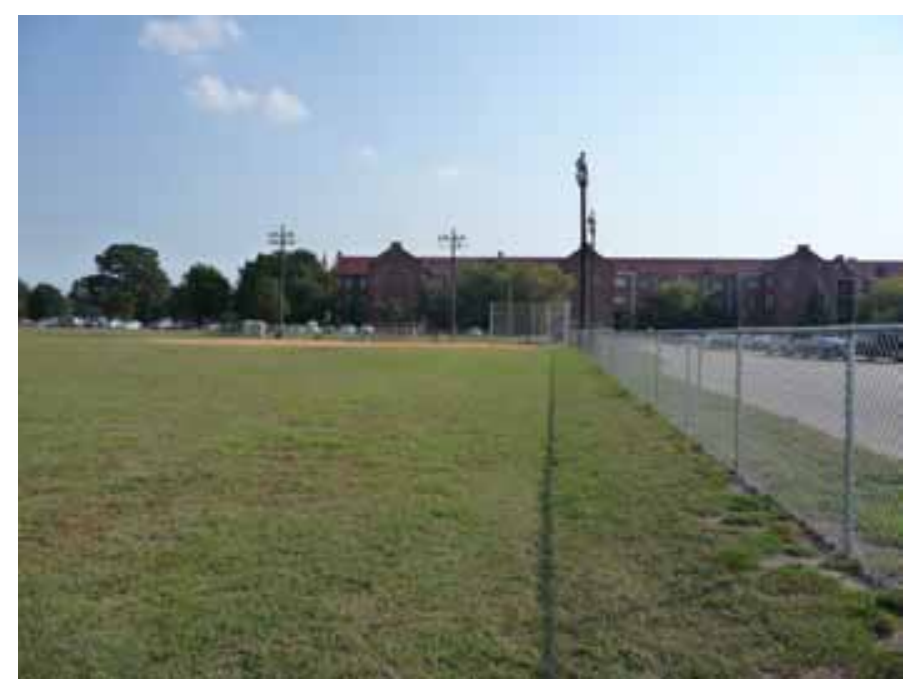

Figure 135. Ruth Field, 2010 (ERDC-CERL).

\section{Design Recommendations}

- The baseball fields should remain as open space in the historic district.

- The main purpose of the fields should remain as a recreational area in the cantonment; the diamonds should be maintained as such.

- Maintain the baseball fields as part of the historic barracks complex.

- Changes to the non-contributing area on both sides of J ackson Street east of the Ruth field should consider the visual and spatial relationship of the field with the rest of the OPHD.

\section{Industrial Area}

Historic Characteristics

- The industrial area on the northeast side of the OPHD has efficient connections to the existing Cape Fear rail network (Figure 136).

- The orientation of the buildings in the industrial area relates to the layout of the railroad tracks.

- The buildings in this area (Figures 137-140) were predominantly used for manufacturing and storage, consequently the architecture of the area is utilitarian.

\section{Existing Conditions}

The industrial area of the OPHD currently contains warehouses and storage facilities and retains much of its interwar era character. There is no formal landscape design for the industrial area resulting in sparse vegetation. There are some trees along Macomb and Scott Streets. 


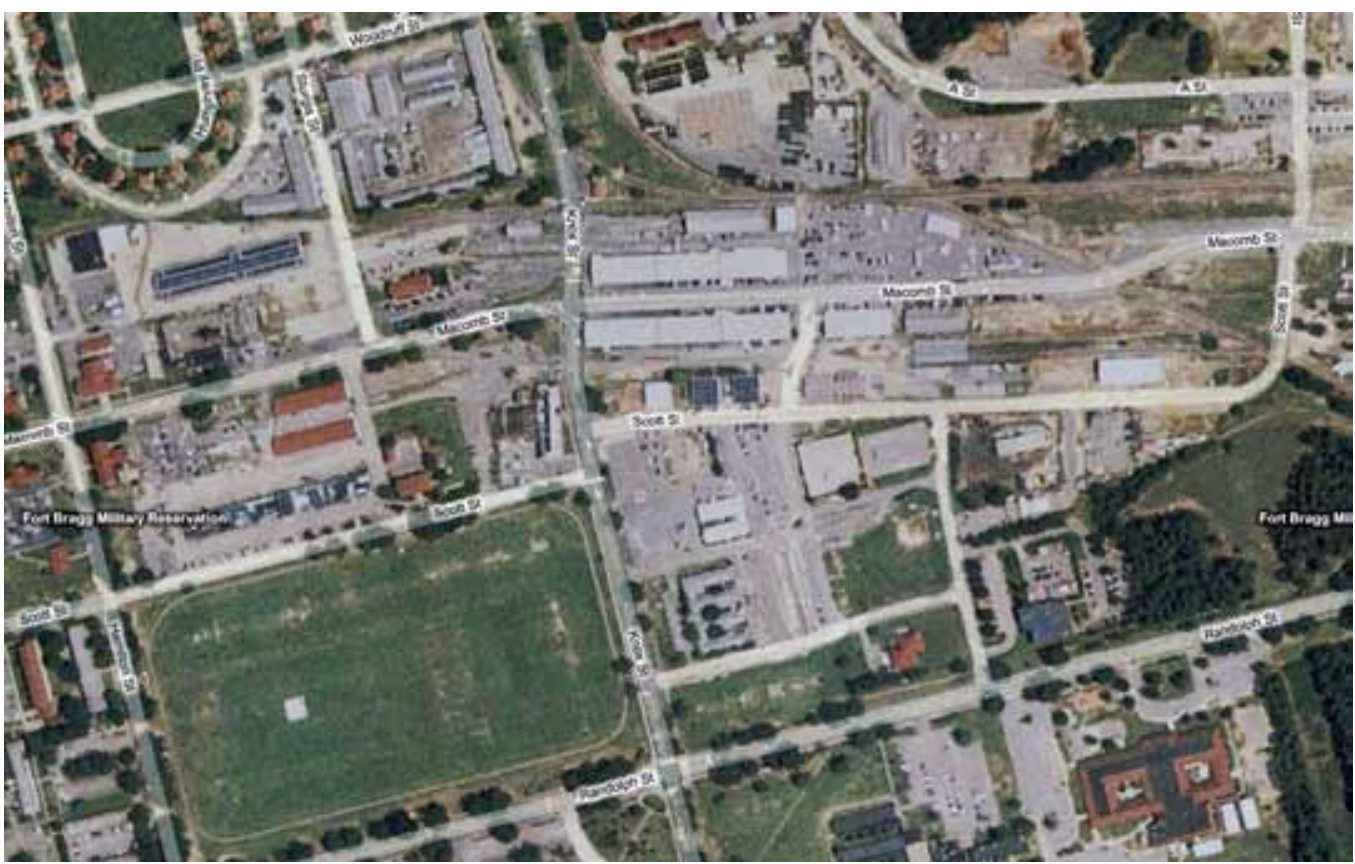

Figure 136. Aerial view of the OPHD industrial area, 2010 (Microsoft Corp, NAVTEQ, USGS).

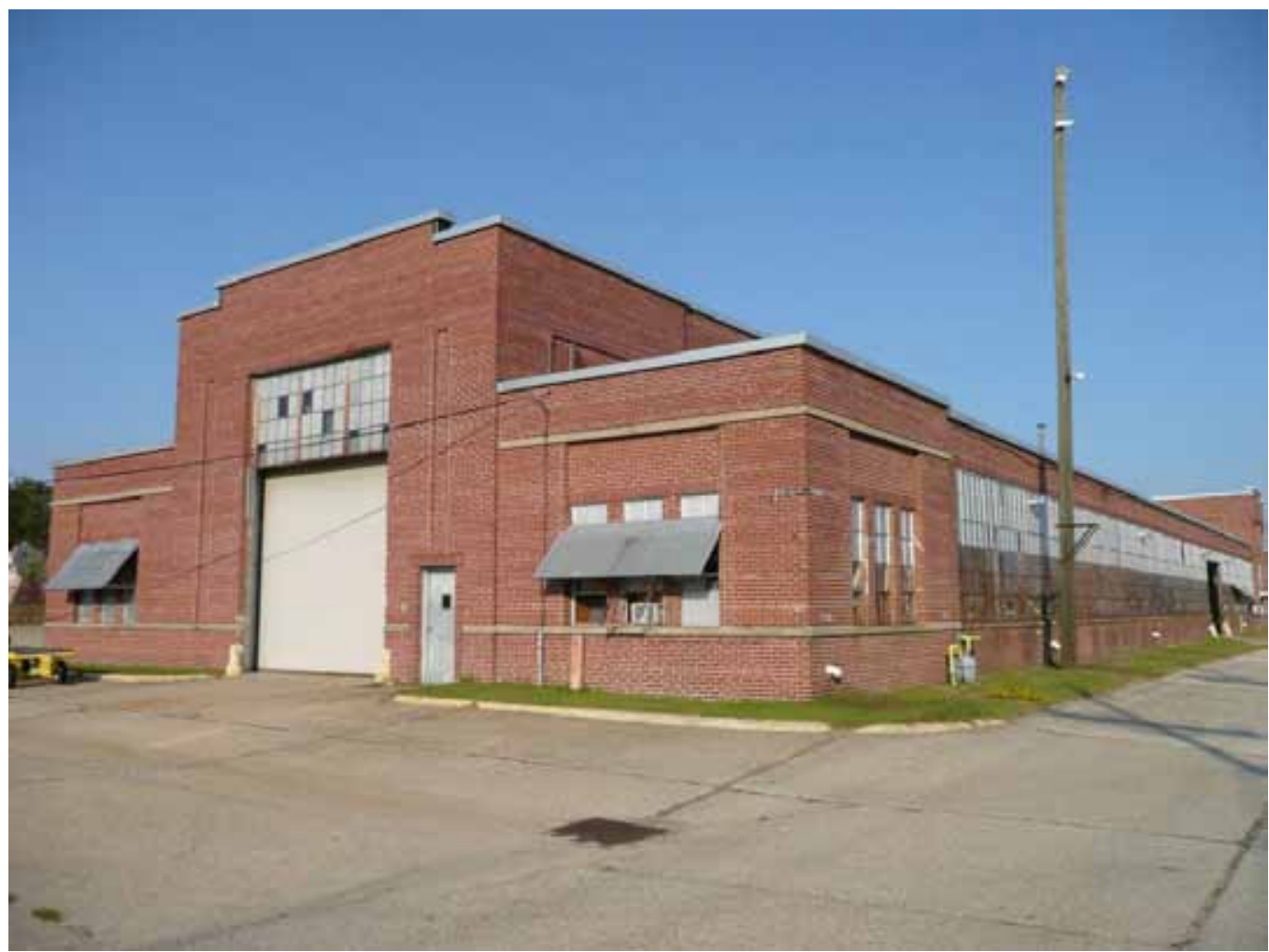

Figure 137. Former ordnance manufacturing building in the industrial area, 2007 (ERDC-CERL). 


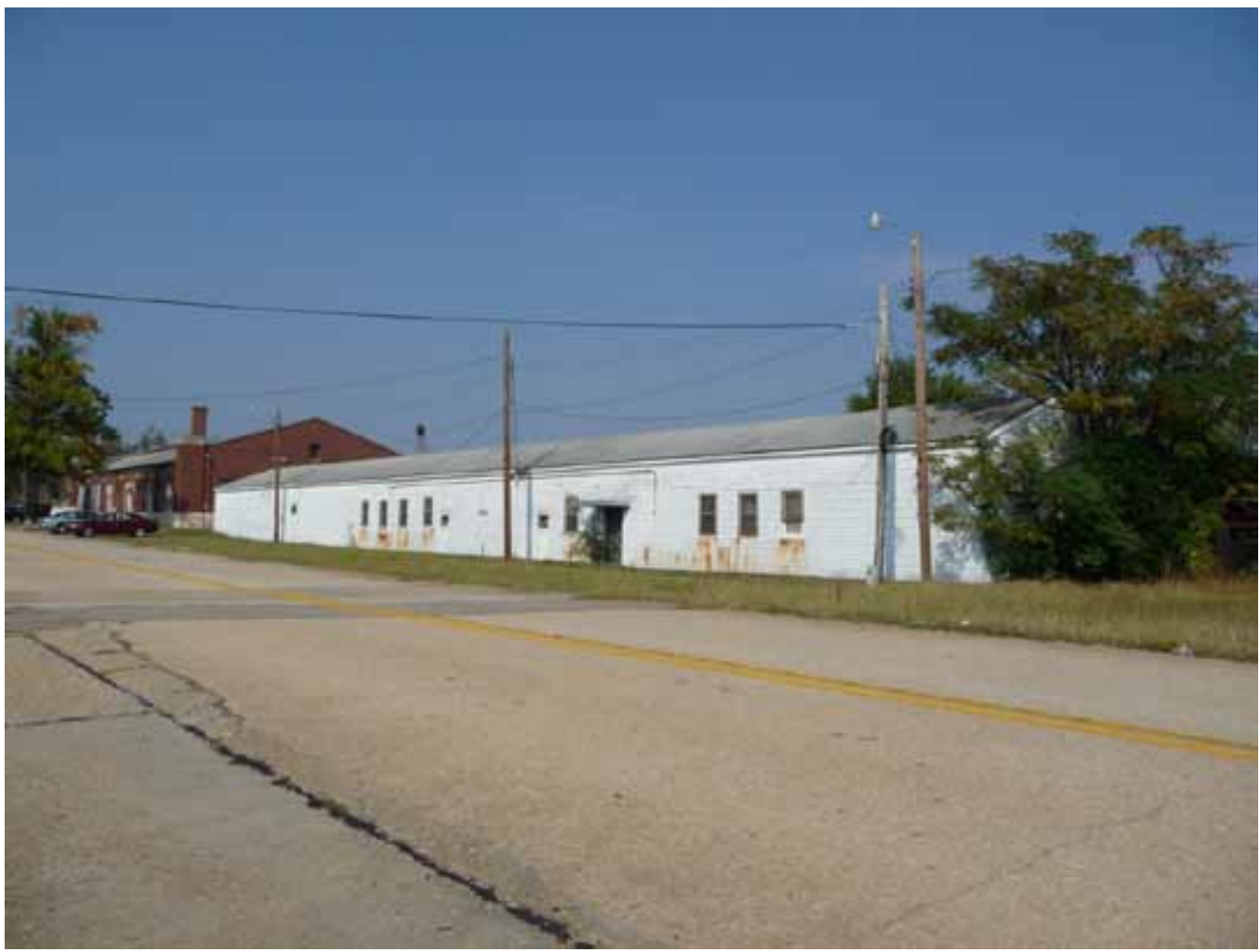

Figure 138. Former warehouse in the industrial area, 2010 (ERDC-CERL).

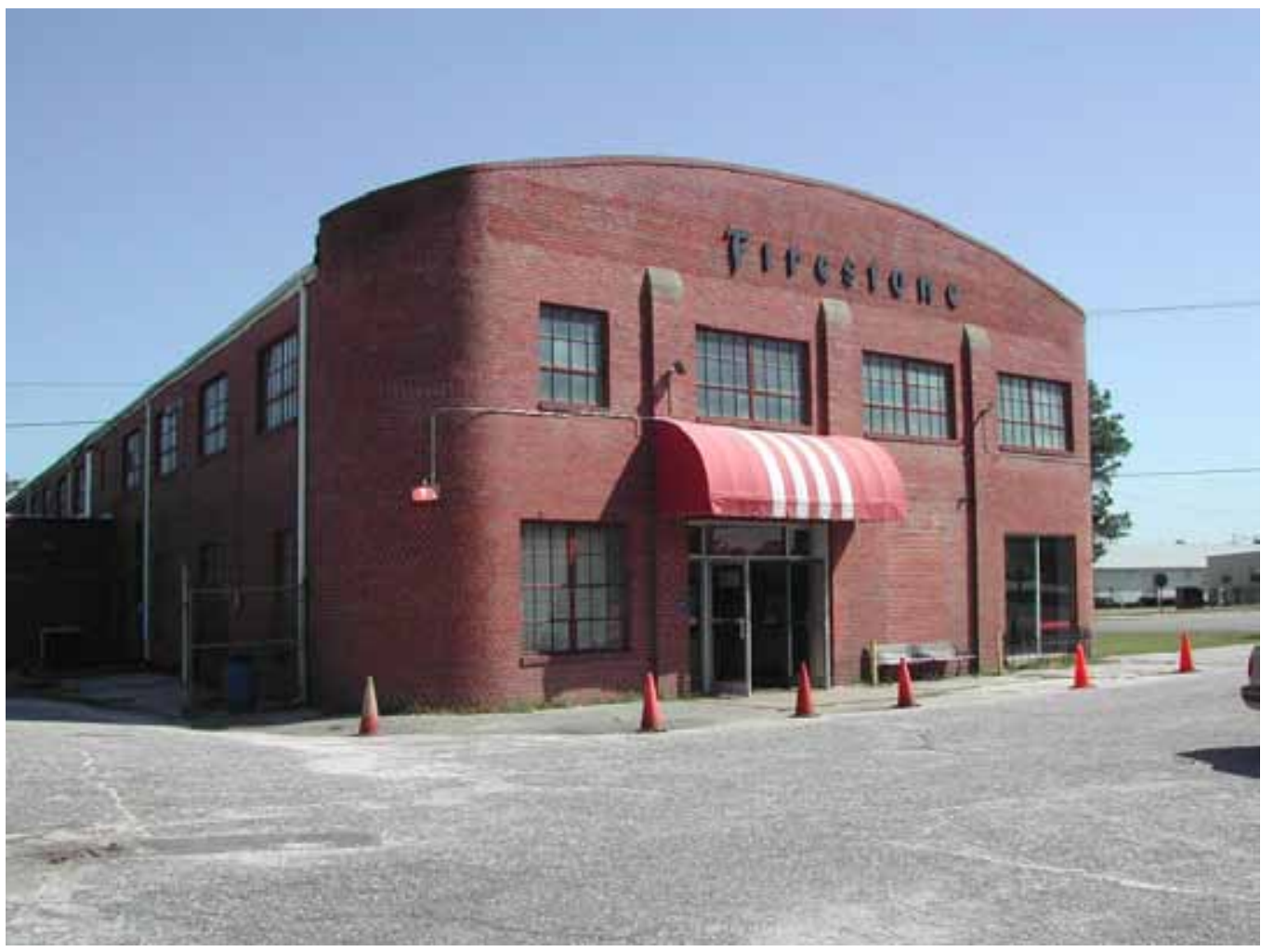

Figure 139. Former Firestone building in the industrial area, 2007 (Fort Bragg Cultural Resources). 


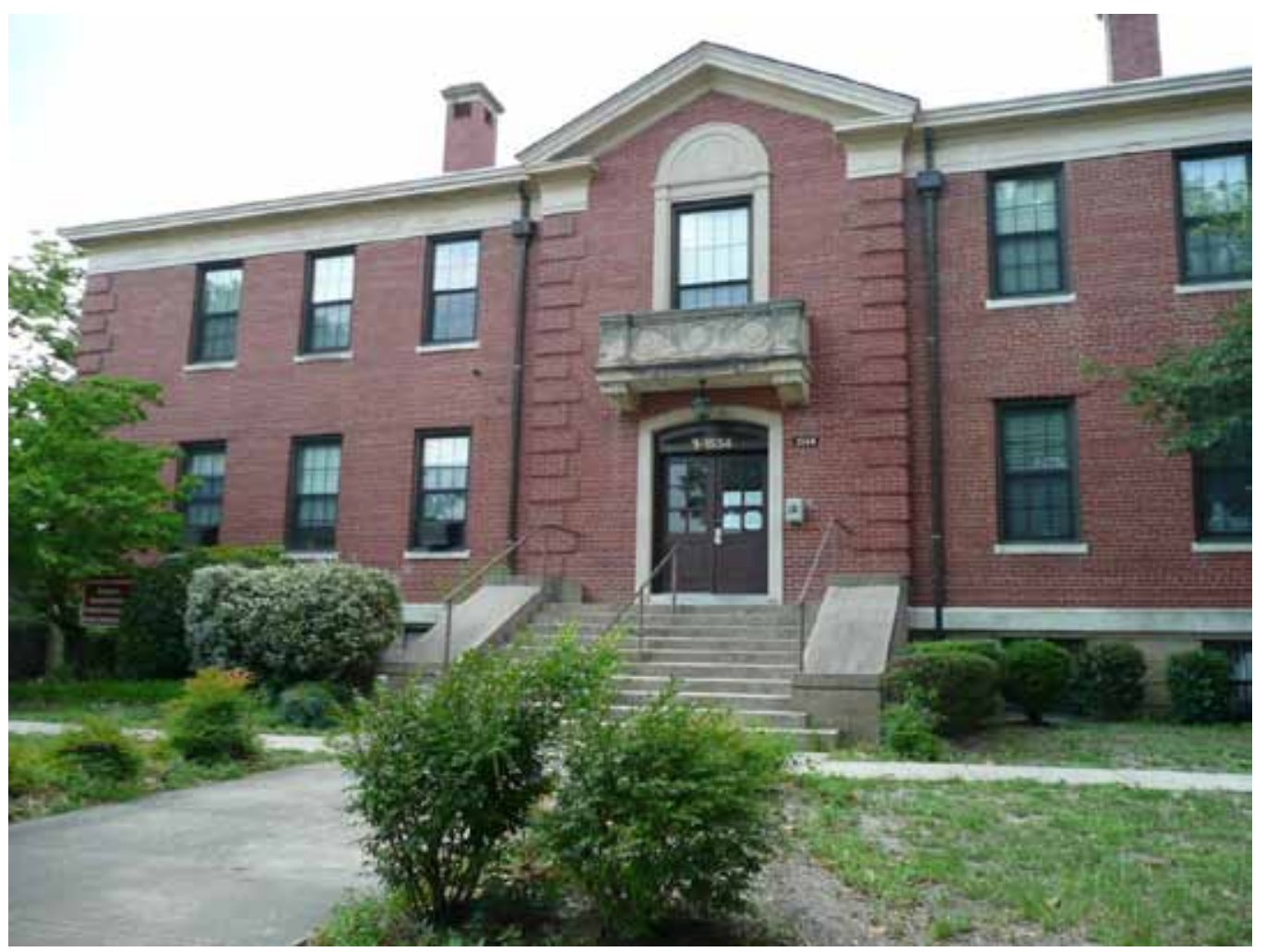

Figure 140. Administrative building, former Field Atillery Board Headquarters, in industrial area, 2009 (ERDC-CERL).

\section{Design Recommendations}

- Maintain the original organization of buildings, if possible preserving the visual and spatial relationships of the industrial area with the rest of the OPHD.

- While there is no historic planting plan for the area, a minimal planting strategy should be implemented. The utility of the buildings should be retained.

- Street trees should line the block per the overall guidelines for the historic district. See Appendix B for the 1933 standardized street tree planting guidelines.

- Planting plans similar to the former headquarters and hospital buildings should be followed for the administrative building (1-1554) in this area. 


\section{Plant List}

Preserving the historic character of the OPHD is a priority. As the installation grows, changes to the historic district should emphasize the historic landscape. As mentioned in Chapter 5, a method for preserving the historic landscape involves construction in ways compatible with the interwar era layout of the district. Moreover, using historical planting designs and palettes are an effective way of emphasizing the historic character of the district. Fort Bragg is the first Army installation to use long-term planning that incorporates sustainability principles. The methods used to preserve the historic qualities of the OPHD should complement the installation's sustainability initiatives.

During the interwar years, the layout of the OPHD was formalized and the majority of the permanent buildings were constructed. At Fort Bragg, the development of the historic district is documented through maps and aerial photographs, but records of the planting plans from this era are hard to find. Several sources do exist, but determining the plantings used during the interwar years at Fort Bragg involves interpolating between planting plans, historical photographs, existing vegetation, and general trends for landscapes and gardens at the time.

In 1933, the Army developed standardized planting plans as well as standardized building plans. These documents include a plant list, exemplary plans, and elevations of major building types illustrating planting strategies (See Appendix B for drawings). These standardized plans were circulated as Fort Bragg was beginning its permanent construction, so it is highly likely these were seen and possibly used by Fort Bragg. However, there is no recorded instance of their use. The 1933 standardized plans are the only record of possible design intent, character, and formality that the Quartermaster Corps and the Army desired for permanent posts at the time Fort Bragg was being constructed.

Most of the completion photographs available for Fort Bragg were taken either prior to the addition of landscape material, or afterward in photographs in which the landscape material is so small that the types and varieties are not identifiable. (Completion photographs are taken at the end 
of construction to close and document the contract process.) Later photographs do show vegetation patterns, but determining species from these is difficult. A 1966 tree and planting legend for Quarters 1 provide species, but not placement. Using these sources the following historical planting strategies for Fort Bragg were constructed:

- Street trees were prominent throughout the Old Post, especially prevalent in the residential areas, along significant streets, and around the parade and polo fields and the open spaces in the neighborhoods.

- The administrative buildings share similar planting patterns. Because the buildings are long, the front façades had groupings of mediumsized evergreen shrubs, usually junipers, at the buildings' corners and medium-sized shrubs were used around main entrances. Along the foundations were regularly spaced evergreen shrubs, either junipers or boxwoods.

- Civic buildings, such as the Chapel, Officers' Club, and Theater were surrounded with larger evergreen shrubs grouped at the corners, and small ornamental trees near entrances. These areas also used dwarf shrubs as accents along walkways.

- Neighborhoods exhibited a wider variety of plant materials including large trees, evergreen and flowering shrubs, small ornamental trees, and vines.

- In open areas such as the parade field, polo field, and the neighborhood parks, shrubs were used to accent and delineate spaces. For example, on the parade field, the flagpole area is defined by large, regularly spaced evergreen shrubs.

The Army has adopted the Leadership in Energy and Environmental Design (LEED) standards to use as a model in becoming more sustainable. Based on LEED standards, Fort Bragg has developed the Installation Design Guide for a Sustainable Fort Bragg (IDG), which provides guidance for the installation's future growth and development. The IDG can serve as a guide in selecting planting materials that are sustainable (Fort Bragg, NC 2009).The IDG guidelines should be used for future considerations within the OPHD. The IDG specifies a Practical Plantings list, which is a reference of native plants to be used at Fort Bragg. To effectively retain the character of the OPHD while also incorporating sustainability principles, one should consider a few issues when making changes:

- Replace plants in-kind unless the historical variety is an invasive or non-native species. When replacing plants, make sure the plant's size, 
texture, massing, and placement in the landscape is consistent with what it is replacing. Also check the availability of cultivars. Cultivars can provide disease-free and lower maintenance options to the original species.

- Many of the historical planting recommendations are not native to the Fort Bragg region. Plants native to a region have many advantages over introduced plants. When choosing new plants consider selecting native plants that have the same characteristics as the historic varieties; native plants require relatively little upkeep, are drought tolerant, and can help attract a diversity of wildlife (Moorman et al 1992).

- Plant species that have been classified as invasive only if they are historically accurate and only with the approval of the Arbor Board (Appendix $\mathrm{C}$ ). If replacing a historically accurate invasive with a native alternative, choose a specimen sharing similar qualities in size, habit, and characteristics, such as fall color, flowering times, and texture.

Although not invasive, the Red Tip Photinia (Photinia x fraseri), is a problem plant in the OPHD. They are susceptible to a fungal leaf spot, which results in plant death over time. The photinia has been used extensively in the historic district as a hedge plant. Although the photinia is a historical species at Fort Bragg it should be replaced as needed when die-off occurs. There are several native substitutes with similar characteristics as the Red Tip Photinia. They include: Carolina Cherry Laurel (Prunus caroliniana) (Figure 141), many types of viburnums, Wax myrtle (Myrica cerifera) (Figure 142), or taller varieties of the Yaupon holly (Ilex vomitoria) (Figure 143) (Moorman et al 1992; Slater, Russ, and Blake 2007). 


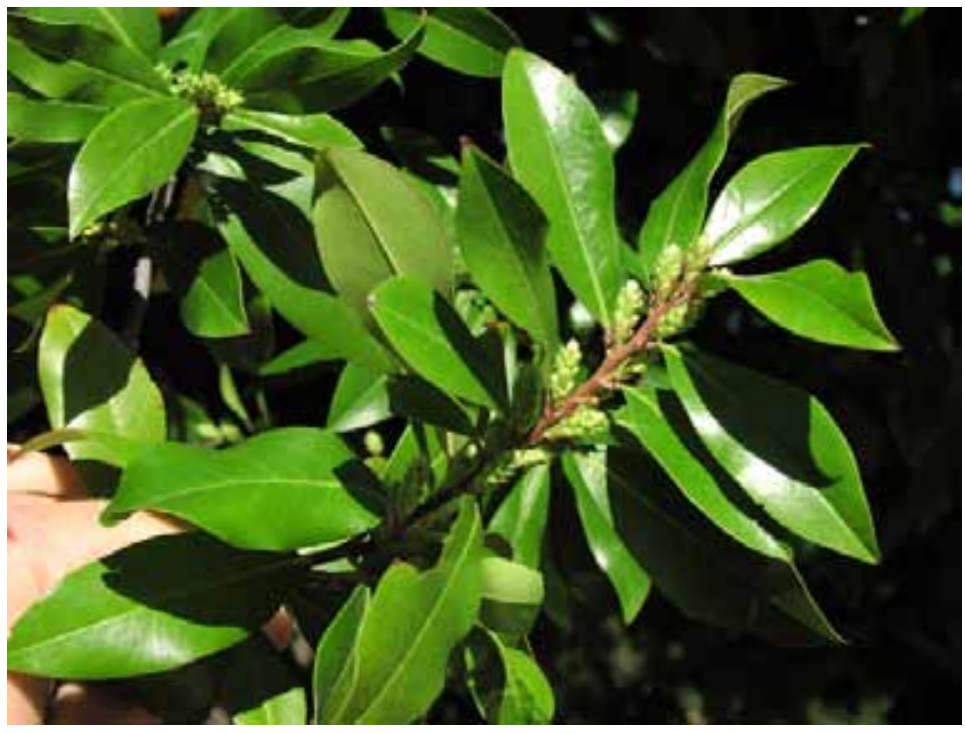

Figure 141. Leaf structure of the Carolina Chemy Laurel, 2005 (University of Texas at Austin).

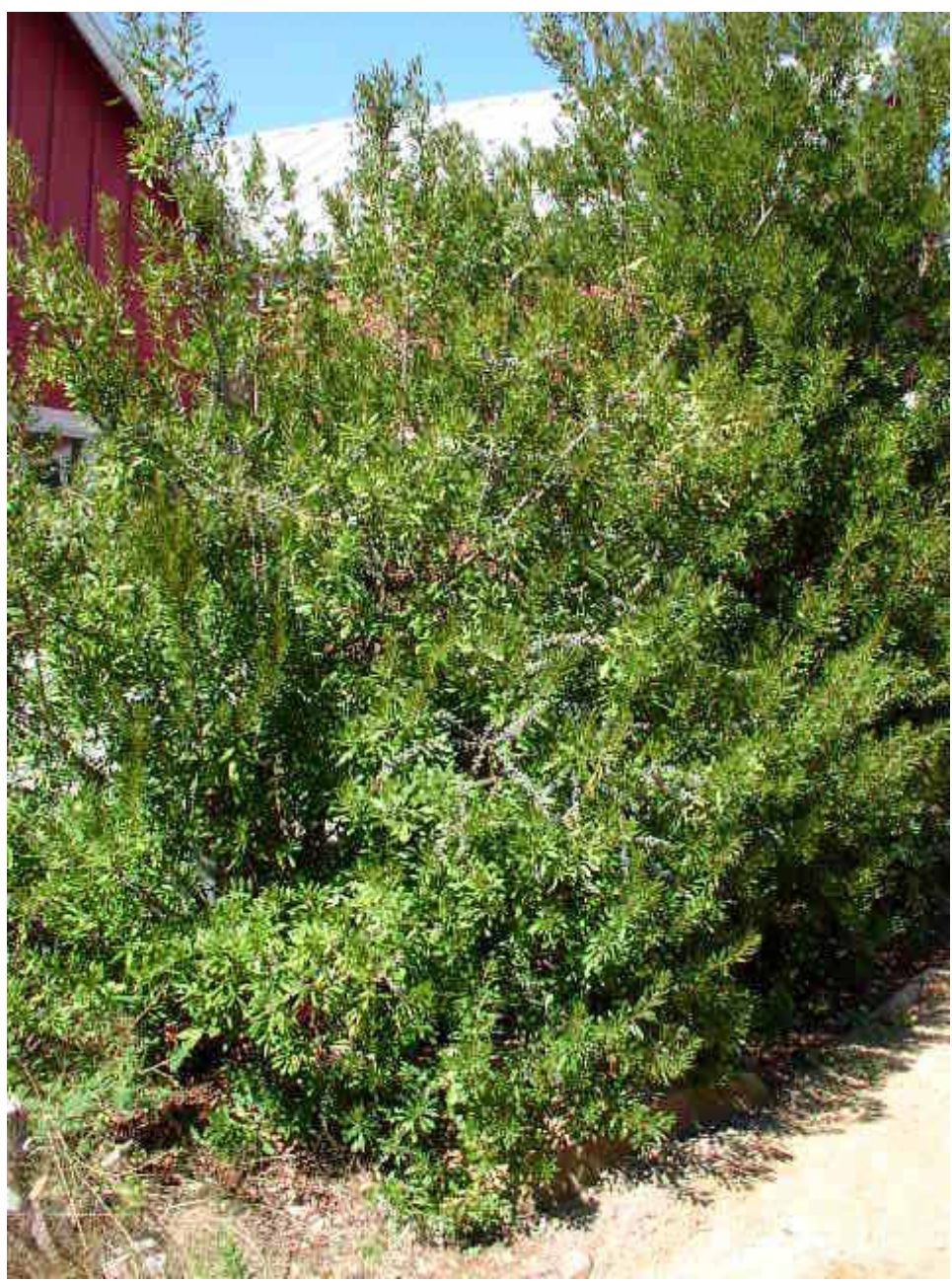

Figure 142. Wax Myrtle, 2005 (University of Texas at Austin). 


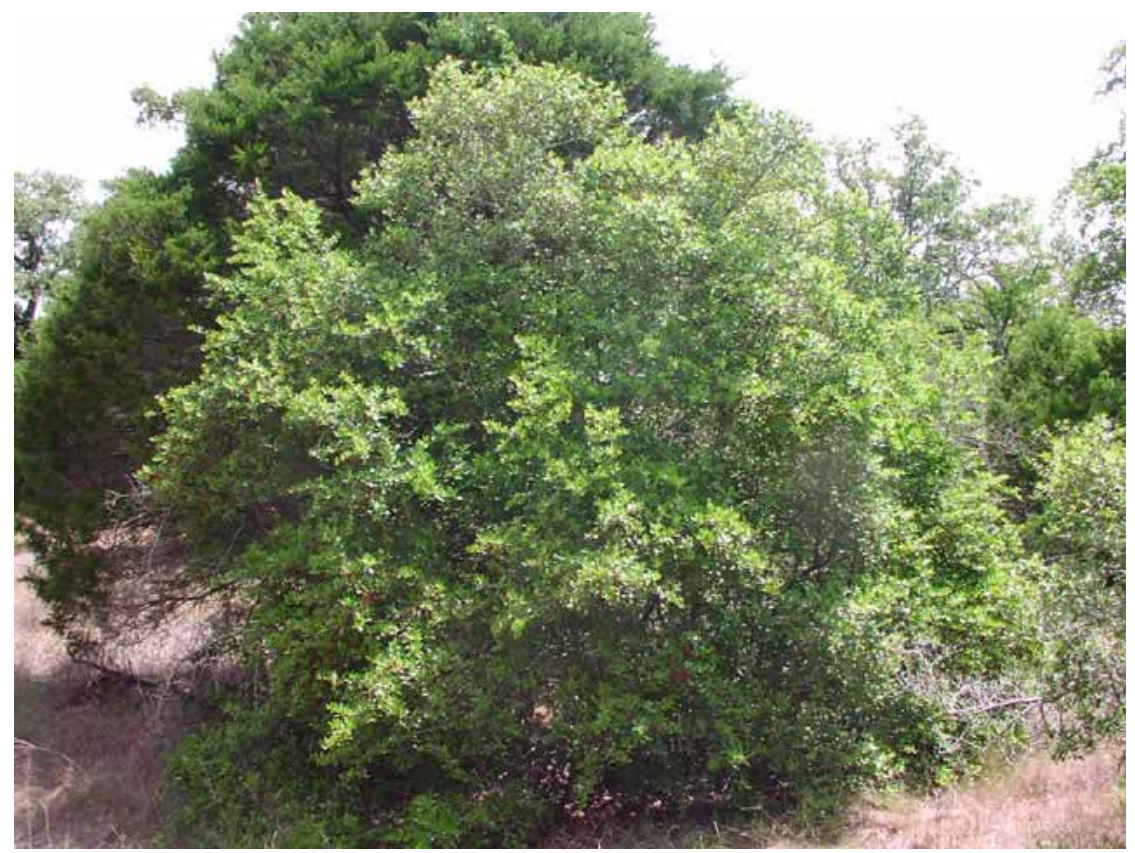

Figure 143. Yaupon Holly, 2005 (University of Texas at Austin).

The plants used in the 2010 design recommendations for the OPHD were chosen from the Army's 1933 standardized planting plan and Fort Bragg's 2009 IDG Practical Planting lists. Because the historical landscape characteristics of the OPHD are being preserved, the 1933 plant list serves as the basis for vegetation options. However since Fort Bragg is working toward being a sustainable installation, for plant choices, the 1933 list is supplemented with recommendations from the most recent IDG Practical Planting guide. The following three tables should be used for choosing plants for the OPHD. Table 2 lists plants that occur on both the 1933 standardized list and the 2009 IDG Practical Planting list. These plants are most historically and regionally appropriate. Table 3 lists additional plants from the 1933 standardized planting list that are historically appropriate and will work in the Fort Bragg region. Table 4 lists additional plants from the 2009 IDG Practical Plantings list that are regionally appropriate, but might not be as historically accurate. Using these lists can aid in selecting appropriate plants for the OPHD.

Appendix C includes the comprehensive plant list from the 1933 standardized planting plan, to which species characteristics have been added. Appendix D includes the complete IDG Practical Planting list, a table of species native to North Carolina, and for a list of plants never to be planted at Fort Bragg. 


\section{List of Historically and Regionally Appropriate Plants}

Table 2. Plants used in the 2010 design recommendations occuring on both the 1933 standardized planting plans for the OPHD and the Fort Bragg 2009 IDG Practical Plantings list (ERDC-CERL).

\begin{tabular}{|c|c|c|c|}
\hline & Native & Scientific Name & Common Name \\
\hline \multicolumn{4}{|l|}{ Large Trees } \\
\hline 1933/IDG 2009 & Native & Acer rubrum & Red (Swamp) Maple \\
\hline 1933/IDG 2009 & Native & Liriodendron tulipifera & Tuliptree \\
\hline 1933/IDG 2009 & Native & Magnolia grandiflora & Southern Magnolia \\
\hline 1933/IDG 2009 & Native & Pinus palustris & Longleaf Pine \\
\hline 1933/IDG 2009 & Native & Quercus alba & White Oak \\
\hline \multicolumn{4}{|c|}{ Large Evergreen Trees } \\
\hline 1933/IDG 2009 & Native & Magnolia grandiflora & Southern Magnolia \\
\hline \multicolumn{4}{|c|}{ Medium Evergreen Trees } \\
\hline 1933/IDG 2009 & Native & Ilex opaca & American Holly \\
\hline \multicolumn{4}{|l|}{ Omamental Trees } \\
\hline 1933/IDG 2009 & Native & Cercis canadensis & American Redbud \\
\hline 1933/IDG 2009 & Native & Cornus florida & Flowering Dogwood \\
\hline \multicolumn{4}{|l|}{ Small Trees } \\
\hline 1933/IDG 2009 & Native & Oxydendrum arboretum & Sourwood \\
\hline \multicolumn{4}{|c|}{ Large Shrubs/Small Trees (rounded habit) } \\
\hline 1933/IDG 2009 & & Lagerstroemia indica & Crape Myrtle \\
\hline 1933/IDG 2009 & & Rhododendrons & Rhododendrons \\
\hline \multicolumn{4}{|c|}{ Large Shrubs/Small Trees (evergreen) } \\
\hline 1933/IDG 2009 & & Camellia japonica & Common Camellia \\
\hline \multicolumn{4}{|l|}{ Medium Shrubs } \\
\hline 1933/IDG 2009 & & Azalea kurume-in variety & Kunume Azaleas \\
\hline
\end{tabular}




\section{List of Historically Appropriate Plants}

Table 3. List of plants from the 1933 standardized planting plan that are historically appropriate as well as regionally acceptable to use in the OPHD at Fort Bragg (ERDC-CERL).

\begin{tabular}{|c|c|c|c|}
\hline & Native & Scientific Name & Common Name \\
\hline \multicolumn{4}{|c|}{ Large Trees } \\
\hline 1933 & Native & $\begin{array}{l}\text { Platanus } \\
\text { occidentalis }\end{array}$ & American Plane Tree or Sycamore \\
\hline 1933 & & Quercus rubra & Red Oak \\
\hline 1933 & Native & Ulmus americana & American Elm \\
\hline \multicolumn{4}{|c|}{ Large Evergreen Trees } \\
\hline 1933 & & Abies-in variety & White, Frazer, Nordmann \& Douglas Fir \\
\hline 1933 & & Cedrus atlantica & Atlas Cedar \\
\hline 1933 & & Cedrus deodara & Deodar \\
\hline 1933 & & Picea-in variety & White, Norway, Oriental, Colorado Spruce \\
\hline 1933 & & Pinus nigra & Austrian Pine \\
\hline 1933 & & Pinus resinosa & Red Pine \\
\hline 1933 & Native & Pinus strobus & White Pine \\
\hline 1933 & & Pinus sylvestris & Scotch Pine \\
\hline 1933 & Native & Taxodium distichum & Common Bald Cypress \\
\hline 1933 & & $\begin{array}{l}\text { Tsuga } \\
\text { canadensis }\end{array}$ & Canadian Hemlock \\
\hline \multicolumn{4}{|c|}{ Large Evergreen Trees (columnar habit) } \\
\hline 1933 & Native & Juniperus virginiana & Red Cedar \\
\hline 1933 & Native & J uniperus virginiana 'Canaertii' & $\begin{array}{l}\text { Cannart Eastem Red Cedar (now Canaert } \\
\text { Red Cedar) }\end{array}$ \\
\hline 1933 & Native & Juniperus virginiana ‘Glauca’ & Silver Eastem Red Cedar \\
\hline 1933 & & Thuja occ. Pyramidalis & American Pyramidal Arbonitae \\
\hline \multicolumn{4}{|c|}{ Small/ Medium Evergreen Trees (columnar habit) } \\
\hline 1933 & & Juniperus hibernica & Irish Juniper \\
\hline 1933 & & Juniperus suecica & Swedish J uniper \\
\hline 1933 & & Taxus baccata hibernica & Irish Yew \\
\hline \multicolumn{4}{|c|}{ Omamental Trees } \\
\hline 1933 & Native & Chionanthus virginica & White Fringe Tree \\
\hline 1933 & Native & Crataegus phaenopyrum & Washington Hawthome \\
\hline 1933 & Native & Malus coronaria-etc. & Wild Sweet Crabapple \\
\hline \multicolumn{4}{|c|}{ Small Trees } \\
\hline 1933 & & Euonymus bungeanus & WinterbernyEuonymus \\
\hline \multicolumn{4}{|c|}{ Large Shrubs/Small Trees (rounded habit) } \\
\hline 1933 & & Buxus sempenvirens & Common American Boxwood \\
\hline 1933 & Native & Laurocerasus-in variety & Carolina Chemy Laurel \\
\hline 1933 & & Photinia serrulata & Evergreen Low Photinia \\
\hline 1933 & & Syringa-in variety & Lilacs \\
\hline 1933 & Native & Vaccinium corymbosum & Highbush Blueberry \\
\hline 1933 & Native & Vibumum-in variety & Vibumums \\
\hline
\end{tabular}




\begin{tabular}{|c|c|c|c|}
\hline \multicolumn{2}{|c|}{ Native } & Scientific Name & Common Name \\
\hline \multicolumn{4}{|c|}{ Large Shrubs/Small Trees (evergreen) } \\
\hline 1933 & & Berberis julianae & Wintergreen Barberry \\
\hline 1933 & & Buxus suffruticosa & English or Truedwarf Boxwood \\
\hline 1933 & Native & Ilexglabra & Inkberry \\
\hline 1933 & & Lonicera nitida & Shining Honeysuckle \\
\hline 1933 & Native & Myrica carolinensis & Northem Bayberry \\
\hline \multicolumn{4}{|c|}{ Medium Shrubs } \\
\hline 1933 & & Jasminum nudiflorum & Winter Jasmine \\
\hline 1933 & & Juniperus pfitzeriana & Pfitzer's J uniper \\
\hline \multicolumn{4}{|c|}{ Small Shrubs } \\
\hline 1933 & & Berberis verruculosa & Warty Barberry \\
\hline 1933 & & Cotoneaster horizontalis & Rock Cotoneaster \\
\hline 1933 & & Lonicera pileata & Privet Honeysuckle \\
\hline 1933 & & Vibumum opulus Nanum & Dwarf Cranberrybush \\
\hline \multicolumn{4}{|c|}{ Groundcovers } \\
\hline 1933 & & Juniperus horizontalis Douglasii & Waukegan Juniper \\
\hline 1933 & & Juniperus squamata & Singleseed J uniper \\
\hline 1933 & & Lantana & Dwarf Lantana \\
\hline 1933 & & Taxus baccata ‘Repandens' & Repandens English Yew \\
\hline
\end{tabular}




\section{List of Regionally Appropriate Plants}

Table 4. List of plants from the 2009 Installation Design Guidelines that are acceptable to use in the OPHD at Fort Bragg (ERDC-CERL).

\begin{tabular}{|c|c|c|c|}
\hline & Native & Scientific Name & Common Name \\
\hline \multicolumn{4}{|c|}{ Large Trees } \\
\hline IDG 2009 & & Chamaecyparis thyoides & Atlantic White Cedar \\
\hline IDG 2009 & & Quercus laurifolia & Darlington Oak \\
\hline IDG 2009 & & Quercus phellos & Willow Oak \\
\hline IDG 2009 & & Quercus virginiana & Live Oak \\
\hline \multicolumn{4}{|c|}{ Omamental Trees } \\
\hline IDG 2009 & & Prunus angustifolia & Chickasaw Plum \\
\hline \multicolumn{4}{|c|}{ Small Trees } \\
\hline IDG 2009 & & Ilex vomitoria & Yaupon Tree \\
\hline \multicolumn{4}{|c|}{ Large Shrubs/Small Trees (rounded habit) } \\
\hline IDG 2009 & & Amelanchier arborea & Senviceberny \\
\hline IDG 2009 & & Kalmia latifolia & Kalmia \\
\hline IDG 2009 & & Hydrangea quercifolia & Oakleaf Hydrangea \\
\hline IDG 2009 & & Myrica cerifera & Wax Myrtle \\
\hline IDG 2009 & & Nerium oleander & Oleander \\
\hline \multicolumn{4}{|c|}{ Medium Shrubs } \\
\hline IDG 2009 & & Clethra alnifolia & Sweet Pepperbush \\
\hline IDG 2009 & & Gardenia spp. & Gardenia \\
\hline IDG 2009 & & Euonymus americanus & StrawberryBush \\
\hline \multicolumn{4}{|c|}{ Small Shrubs } \\
\hline IDG 2009 & & Crataegus spp. & Hawthome \\
\hline IDG 2009 & & Gardenia spp. & Dwarf Gardenia \\
\hline IDG 2009 & & Hosta lancifolia & Big Hosta \\
\hline IDG 2009 & & Ilex vomitoria 'Nana' & Dwarf Yaupon \\
\hline IDG 2009 & & Nandina domestica & Dwarf Nandina \\
\hline \multicolumn{4}{|c|}{ Groundcovers } \\
\hline IDG 2009 & & Phloxspp. & Phlox \\
\hline IDG 2009 & & Vinca major & Periwinkle spp. \\
\hline IDG 2009 & & Vinca minor & Periwinkle spp. \\
\hline
\end{tabular}




\section{Conclusion}

Fort Bragg's OPHD is well maintained and its historic developments are clearly seen in the physical landscape of the district. Although the historic district has seen changes, the overall quality and characteristics of the area remain consistent as the cantonment has grown. The OPHD is a good example of the military's execution of Beaux Arts style planning principles and interwar era standardized architectural design.

This report documents the historic landscapes of the OPHD and evaluates them for their military significance and integrity. This report identified several landscapes that are significant to military history, history of Fort Bragg, as well as to the history of urban planning in the United States. These landscapes include the parade ground, Normandy Heights and Bastogne Gables Housing Areas, Ryder Golf Course, polo field, the mule barn area, and support buildings' contextual areas, such as around the chapel, theater, headquarters, BOQ, Officers' Club, and the former hospital and nurses' quarters and barracks. In addition, recommendations have been made to help preserve the historic characteristics of the district as well as to allow Fort Bragg to meet mission requirements and continue to grow. Planting plans are included for several of the prominent support buildings and the residential types and styles. A plant list has been generated based on the historic planting plans from the 1930s and pest and disease-free sustainable plant material. 


\section{Acronyms and Abbreviations}

$\begin{array}{ll}\text { Term } & \text { Spellout } \\ \text { AEC } & \text { Army Environmental Command } \\ \text { ANSI } & \text { American National Standards Institute } \\ \text { AT/FP } & \text { Antiterrorism Force Protection } \\ \text { BOQ } & \text { Bachelor Officers' Quarters } \\ \text { CERL } & \text { Construction Engineering Research Laboratory } \\ \text { COQ } & \text { Commanding Officer's Quarters } \\ \text { ERDC } & \text { Engineer Research and Development Center } \\ \text { GIS } & \text { geographic information system } \\ \text { HGIC } & \text { Home \& Garden Information Center } \\ \text { IDG } & \text { Installation Design Guide } \\ \text { LEED } & \text { Leadership in Energy and Environmental Design } \\ \text { MIPR } & \text { Military Interdepartmental Purchase Request } \\ \text { NARA } & \text { National Archives and Records Administration } \\ \text { NCO } & \text { non-commissioned officer } \\ \text { NHPA } & \text { National Historic Preservation Act of 1966 } \\ \text { NRHP } & \text { National Register of Historic Places } \\ \text { NSN } & \text { National Supply Number } \\ \text { OMB } & \text { Office of Management and Budget } \\ \text { OPHD } & \text { Old Post Historic District } \\ \text { SAR } & \text { SAME as Reportk } \\ \text { TR } & \text { Technical Report } \\ \text { URL } & \text { Universal Resource Locator } \\ \text { USASOC } & \text { U.S. Army Special Operations Command } \\ \text { USGS } & \text { U.S. Geological Survey } \\ \text { WM } & \text { World War I } \\ \text { WMI } & \text { World War II } \\ & \end{array}$




\section{References}

Army Navy Register. 12 April 1941, vol. 6.

Ashe, Samuel A. 1971. History of North Carolina, Vol. II (1783- 1925). Reprint of 1925 edition. Spartanburg, SC: Reprint Company.

Assistant Chief of Staff (Acofs), Office of, G-3, Headquarters, XVIII Airborne Corps and Fort Bragg, NC.1967. History of Ft. Bragg 1918-1967, MS on file at Environmental Office, Fort Bragg, NC.

Bartlett, Charles S., J r. 1967. Geology of the Southern Pines Quadrangle North Carolina. Unpublished Master's thesis, Department of Geology. Chapel Hill, NC: University of North Carolina.

Belew, Kenneth, and Douglas D. Scott. 1997. Cavalry Clash in the Sandhills: The Battle of Monroe's Crossroads, North Carolina, 10 March 1865. Lincoln, NE: National Park Service, Midwest Archeological Center; and Tallahassee, FL: Southeast Archeological Center, http:// www.nps.gov/seac/cavclash.htm

Birnbaum, Charles A. 1994. National Park Service Preservation Brief \#36; "Protecting Cultural Landscapes Planning, Treatment and Management of Historic Landscapes." Washington, DC: National Park Service.

Cannan, Deborah, et al. 1995. National Historic Context for Department of Defense Installations, 1790-1940, vol 1. Frederick, MD: R. Christopher Goodwin and Associates, prepared for U.S. Army Corps of Engineers, Baltimore District, August 1995.

Cheatham, Maj. Gen B.F. 1926. Quartermaster General U.S. Army, U.S. House Committee on Military Affairs, "Housing Program of the Army" (69-2), 1926, H454, 23-25.

Evans, W. McKee. 1967. Ballots and Fence Rails: Reconstruction on the Lower Cape Fear. Chapel Hill, NC: University of North Carolina Press.

Ford, George B. 1909. The Technical Phases of City Planning, in Benjamin Clarke Marshe. An Introduction to City Planning: Democracy's Challenge to the American City. New York: Privately Published.

— 1929. “New Army Posts for Old,” The Quartermaster Review. Nov.-Dec. 1929.

Fort Bragg, NC, Directorate of Public Works. 2007. Fort Bragg Old Post Historic District Design Guidelines. rev. 2009. Cultural Resources Management Program, Environmental Sustainment Division, Fort Bragg, NC.

Fort Bragg, NC. 2009. Installation Design Guide for a Sustainable Fort Bragg (IDG), website, accessed 07 March 2010, http:// www.bragg.army.mil/dpw/idg/html/ex_fr1.htm 
Fort Bragg Cultural Resources. 2010. Old Post Virtual Tour. website, accessed 07 March 2010, http:// uwwbragg.army.mil/ culturalresources/ pages/ old_posthtm

Fort Bragg Public Works and Environment. November 1995. Historical Display at Directorate Public Works and Environment, Fort Bragg.

Fort Bragg Directorate of Public Works. 2007. Rev. 2009. Fort Bragg Old Post Historic District Design Guidelines. Cultural Resources Management Program, Environmental Sustainment Division, Fort Bragg, NC.

Fort Bragg Ryder Golf Course. 2007. Website, accessed April 2010, http:// wuw.fortbraggmwr.com/ sportsred/golf/ nyder/ RyderWkbsite2006/ RyderMain.htm/

Grandine, Katherine. 2010. Fort Monmouth Cantonment Historic District National Register Nomination. In R. Christopher Goodwin and Associates, Inc. 1995. National Historic Context for Department of Defense Installations, 1790- 1940, Vol IV. Prepared for U.S. Army Corps of Engineers Baltimore District, Baltimore, MD, http:/ / aec.army.mil/ usaec/ cultural/ nhc 04.pdf

Hallauer, E. Mack. 1939. “Landscaping the Army Post,” The Quartermaster Review. J ulyAug 1939, pp 28-31.

Haynes, William. 1916. Sandhills Sketches. New York: D.O. Haynes.

Hill, Daniel H. 1926. Bethel to Sharpsburg, vol. I. Raleigh, NC: Edwards Broughton.

“Housing the Army.” 1931. Quartermaster Review, vol 10 (March-April 1931), pp 11-13.

Idol, Bruce S. 1999. Fort Bragg Delivery Order One: Phase I Archaeological Survey of 2,774 Acres (1,123 Hectares), Fort Bragg, Cumberland and Hoke Counties, North Carolina. Revised Draft Report. Submitted to National Park Service, Atlanta, GA by TRC Garrow Associates, Inc., Chapel Hill, North Carolina, Contract No. 144CX509097025.

J ohnson, F. Roy. 1977. Riverboating in Lower Carolina. Murfreesboro, NC: J ohnson Publishing.

King Collection (Henry T. King). 1902b. Notes from Martin's Letters: The History of the State Troops. Copy of original from The Charlotte Observer, 16 February 1902. Collection No. 625. East Carolina Manuscript Collection, J.Y. J oyner Library, Greenville, NC: East Carolina University.

Lawson, J ohn. 1967. A New Voyage to Carolina, Chapel Hill, NC: University of North Carolina Press.

Lee, E. Lawrence. 1963. Indian Wars in North Carolina, 1663- 1763. Raleigh, NC: Carolina Charter Tercentenary Commission.

1965. The Lower Cape Fear in Colonial Days. Chapel Hill, NC: University of North Carolina Press.

Lefler, Hugh T., and William S. Powell. 1973. Colonial North Carolina: A History. New York: Charles Scribner's Sons. 
Little, Ruth M. 2001. Historic Architectural Resources Eligibility Report, Fort Bragg Military Reservation. Raleigh, NC: Longleaf Resources. prepared for Public Works Business Center, Fort Bragg, NC.

Loechl, Suzanne Keith, Samuel A. Batzli, and Susan I. Enscore. 1996. Guidelines for Documenting and Evaluating Historic Military Landscapes: An Integrated Landscape Approach. Army Environmental Command (AEC) Technical Guideline. Champaign, IL: Construction Engineering Research Laboratory, http:// aec.army.mil/ usaec/ cultural/ milland.pdf

Loftfield, Thomas C. 1979. Cultural Resource Reconnaissance of Fort Bragg, Camp Mackall, and Simmons Army Airfield, North Carolina. Coastal Zone Resources Division Ocean Data Systems, Inc., Wilmington. Report submitted to the U.S. Army Corps of Engineers, Savannah District, Contract No. DACA21-77-0139.

McDonald, Heather, and Michelle Michael. 2008. Design Guidelines for Department of Defense Historic Buildings and Districts. Department of Defense Legacy Resource Management Program, Project 07-382., http:/ / wuw.denixosd.mil/ ar/ upload/ 07-382_FNALpdf

Merrens, Harry R. 1964. Colonial North Carolina in the Eighteenth Century: A Study in Historical Geography. Chapel Hill, NC: University of North Carolina Press.

Meyer, D. 1961. The Highland Scots of North Carolina, 1732- 1776. Chapel Hill: University of North Carolina Press.

Moorman, Chris, MarkJ ohns, Liessa Thomas Bowen, Richard Braham, J ohn Connors, J esse Perry, J ohnny Randall, and Rebecca Vidra. 2002. Landscaping for Wildlife with Native Plants, North Carolina Cooperative Extension Service, Greensboro, NC, http:// wuw.ncsu.edu/ goingnative/ ag636 03.pdf

Nakata Planning Group and Rust Environment and Infrastructure. 1994.

Nakata Planning Group and Rust Environment and Infrastructure. 1995.

National Park Service. Undated. National Register Bulletin \#18, How To Evaluate and Nominate Designed Historic Landscapes, Washington, DC: U.S. Department of the Interior, National Park Service.

. 1991. National Register Bulletin \#15, How To Apply the National Register Criteria for Evaluation, Washington, DC: U.S. Department of the Interior, National Park Service.

. 1992. National Register Bulletin \#30, Guidelines for Evaluating and Documenting Rural Historic Landscapes, Washington, DC: U.S. Department of the Interior, National Park Service.

. 1992a. The Secretary of the Interior's Standards for the Treatment of Historic Properties. Washington, DC: U.S. Department of the Interior, National Park Service.

North Carolina Collection. 1919. Camp Bragg and Fayetteville NC. Chapel Hill. NC: University of North Carolina. 
Nurse, 1st Lt. H.B. 1928. “The Planning of Army Posts,” The Quartermaster Review, Sept.-Oct. 1928, pp 14-16.

Nye, W.S. Undated. A History of Fort Bragg. Unpublished manuscript on file, Directorate of Engineering and Housing, Fort Bragg.

Oates, J ohn A. 1950. The Story of Fayetteville, and The Upper Cape Fear. Charlotte, NC: Dowd Press Inc.

Office of Public Relations, Fort Bragg. 1941. Typescript. Collection of Main Post Library, Fort Bragg, NC.

Parramore, Thomas C. 1982. "The Tuscarora Ascendancy." North Carolina Historical Review. 59:307- 326.

— 1987. "With Tuscarora J ack on the Back Path to Bath." North Carolina Historical Review. 64:115- 138.

Ray, Muriel Zimm. 1994. "The Well Planned Post.” George Washington University Master's Thesis.

Scott, Douglas D., and William J . Hunt. 1997. The Civil War Battle at Monroe's Crossroads, Fort Bragg, North Carolina: A Historical Archaeological Perspective. Tallahassee, FL: U.S. Department of the Interior, Southeast Archeological Center, National Park Service.

Simonds, J ohn Ormsbee. 1961. Landscape Architecture: The Shaping of Man's Natural Environment. New York: McGraw-Hill Book Company, Inc.

Slater, Rebecca, Karen Russ, and J ames H. Blake. 2007. “Photinia (Red Tip) HGIC 1081,” Home \& Garden Information Center, Clemson, SC: The Clemson University Cooperative Extension Service, http:/ / unu.demson.edu/ extension/ hgic

Thompson, J ohn K. 1919. Plan - Camp Bragg, Fayetteville, NC, Thompson, J ohn K., Constructing Quartermaster. 1919 plan of Camp Bragg. RG 77, NARA, College Park.

Tullos, Allen. 1989. Habits of Industry: White Culture and the Transformation of the Carolina Piedmont. Chapel Hill, NC: University of North Carolina Press.

U.S. Army Corps of Engineers Seattle District. 1997. Context Study of the United States Quartermaster General Standardized Plans 1866-1942. Aberdeen Proving Ground, MD: U.S. Army Environmental Center.

Ward, Trawick H., and R. P. Stephen Davis, J r. 1993. Indian Communities on the North Carolina Piedmont A.D. 1000 to 1700. Research Laboratories of Anthropology Monograph No. 2. Chapel Hill: University of North Carolina. 


\section{Appendix A: Characteristics, Features, and Landscape Elements Historically Significant in Fort Bragg's Old Post Historic District}

Table A1 lists the characteristics, features, and landscape elements historically significant in Fort Bragg's OPHD. The table is derived from National Register Bulletin \#30: Guidelines for Evaluating and Documenting Rural Historic Landscapes (National Park Service 1992, pp 15-18).

Table A1. Characteristics, features, and documentation used for landscape evaluation, 2010 (ERDC-CERL).

\begin{tabular}{|c|c|c|}
\hline Characteristics & Features & Documentation \\
\hline Site and Layout & $\begin{array}{l}\text { Overall layout of canton- } \\
\text { ment based on site condi- } \\
\text { tions, pre-existing natural } \\
\text { features, and the needs of } \\
\text { the military mission }\end{array}$ & $\begin{array}{l}\text { - Interwar Beaux Arts cantonment layout in } \\
\text { response to } 1918 \text { camp layout } \\
\text { - Layout in response to main circulation } \\
\text { routes like Randolph Street and Reilly Street } \\
\text { - Normandy Heights and Bastogne Gables } \\
\text { neighborhoods organized around central } \\
\text { parks and open space } \\
\text { - Centrally located, chevron-shaped parade } \\
\text { field }\end{array}$ \\
\hline Land Use & $\begin{array}{l}\text { Mission-based organiza- } \\
\text { tion of buildings and land- } \\
\text { scapes }\end{array}$ & $\begin{array}{l}\text { - Officers' housing located prominently along } \\
\text { parade field } \\
\text { - Non-Commissioned Officers' housing less } \\
\text { prominently located } \\
\text { - Barracks located near mission related build- } \\
\text { ing } \\
\text { - Civic buildings centrally located in the dis- } \\
\text { trict } \\
\text { - Recreational areas, such as golf course } \\
\text { located on edges of the district } \\
\text { - Mule bams located at edge of the district } \\
\text { with access to training ranges } \\
\text { - Industrial area near access to national rail } \\
\text { network }\end{array}$ \\
\hline
\end{tabular}




\begin{tabular}{|c|c|c|}
\hline Characteristics & Features & Documentation \\
\hline $\begin{array}{l}\text { Expression of Mili- } \\
\text { tary Cultural Tradi- } \\
\text { tions }\end{array}$ & $\begin{array}{l}\text { Military organization and } \\
\text { aesthetics in layout, land } \\
\text { use, and building design }\end{array}$ & $\begin{array}{l}\text { - Hierarchy visible in location of officers' } \\
\text { quarters, headquarters, barracks, recrea- } \\
\text { tional and industrial spaces } \\
\text { - Centrally located parade field } \\
\text { - Uniformity and repetition in building design } \\
\text { and organization } \\
\text { - Important buildings have more architectural } \\
\text { ornamentation } \\
\text { - Location and minimal aesthetics in utilita- } \\
\text { rian buildings }\end{array}$ \\
\hline $\begin{array}{l}\text { Transportation } \\
\text { Networks }\end{array}$ & $\begin{array}{l}\text { Streets, alleys, or paths, } \\
\text { highways, railways, and } \\
\text { waterways }\end{array}$ & $\begin{array}{l}\text { - Access to railways (1918-1940s) } \\
\text { - Main road Randolph Street to parade field } \\
\text { - Bragg Boulevard the historic connector to } \\
\text { Fayetteville, NC } \\
\text { - } 1918 \text { rectilinear layout based on street grid }\end{array}$ \\
\hline Viewsheds & $\begin{array}{l}\text { Views toward significant } \\
\text { buildings or elements in } \\
\text { the historic district }\end{array}$ & $\begin{array}{l}\text { - Steeple of the Main Post Chapel visible from } \\
\text { many points in the district } \\
\text { - View down Randolph Street toward flagpole } \\
\text { and Iron Mike sculpture } \\
\text { - View of barracks, headquarters, and old } \\
\text { hospital along Amistead Street } \\
\text { - Scenic views like polo field, parade field, } \\
\text { Dupont Plaza, and Humphrey Plaza }\end{array}$ \\
\hline $\begin{array}{l}\text { Custers of Build- } \\
\text { ings and Struc- } \\
\text { tures }\end{array}$ & $\begin{array}{l}\text { Administrative center, Civ- } \\
\text { ic center, barracks, neigh- } \\
\text { borhoods, mule bams. }\end{array}$ & $\begin{array}{l}\text { - Administrative buildings, barracks, and } \\
\text { theater architecturally Georgian Revival in } \\
\text { style } \\
\text { - Residential areas, chapel, and officers' } \\
\text { clubs Spanish Eclectic style } \\
\text { - Normandy Heights and Bastogne Gables } \\
\text { organized according to Beaux Arts planning } \\
\text { principles: rows of buildings surrounding } \\
\text { open space } \\
\text { - The Headquarters and Hospital angled to- } \\
\text { ward the intersection of Armistead Street } \\
\text { and Macomb Street } \\
\text { - Barracks (Building \#s:1-1242, 2-1120, 2- } \\
\text { 1105, 2-1127, 2-1133, 2-1138, 2-1728, 2- } \\
\text { 1731) } \\
\text { - Administrative Buildings: Headquarters } \\
\text { 11333; Hospital 11326; Nurses Quarters } \\
\text { 11621; Bachelor Officers' Quarters 14428 } \\
\text { - Civic Buildings: Chapel 1-1510; Red Cross } \\
\text { Building 1-1139; Theater 1-1202 }\end{array}$ \\
\hline
\end{tabular}




\begin{tabular}{|c|c|c|}
\hline Characteristics & Features & Documentation \\
\hline $\begin{array}{l}\text { Custers of Build- } \\
\text { ings and Struc- } \\
\text { tures (cont'd) }\end{array}$ & $\begin{array}{l}\text { Administrative center, Civ- } \\
\text { ic center, barracks, neigh- } \\
\text { borhoods, mule bams } \\
\text { (cont'd). }\end{array}$ & $\begin{array}{l}\text { - Mule Bams/ Field Artillery Stables: Stable } \\
\text { Guard Quarters 2-2205, 2-2211, 8-4807; } \\
\text { Stables 2-2402, 2-2404, 2-2405, 2-2406, } \\
\text { 2-2408, 2-2409, 2-2411, 2-2412, 2-2414, } \\
\text { 2-2706, 2-2711, 2-2802, 2-2809, 2-2814, } \\
\text { 2-3202, 2-3212, 2-3214, 2-3602, 2-3612, } \\
\text { 2-3614, 8-3710, 8-4003, 8-4608 } \\
\text { - Normandy Heights houses and garages } \\
\text { - Bastogne Gables houses and garages }\end{array}$ \\
\hline Vegetation & $\begin{array}{l}\text { Functional and ornamen- } \\
\text { tal trees and shrubs, tree- } \\
\text { lines along walls and } \\
\text { streets, gardens, allée, } \\
\text { and native vegetation }\end{array}$ & $\begin{array}{l}\text { - Longleaf pine is a significant species in the } \\
\text { region } \\
\text { - Vegetation pattems have remained similar } \\
\text { to historical plantings } \\
\text { - Residential areas planted with omamentals } \\
\text { and species requiring more maintenance } \\
\text { - Administrative and support areas planted } \\
\text { with species requiring less maintenance } \\
\text { and more formal in appearance } \\
\text { - Street trees along Macomb Street, Armis- } \\
\text { tead Street, Randolph Street, Capron Street, } \\
\text { the streets of Normandy Heights, and } \\
\text { Humphrey Plaza, Sturgis Street in Bastogne } \\
\text { Gables neighborhood }\end{array}$ \\
\hline $\begin{array}{l}\text { Small-scale Fea- } \\
\text { tures }\end{array}$ & $\begin{array}{l}\text { Monuments, light poles, } \\
\text { benches, walls, fences, } \\
\text { flagpoles, and signage }\end{array}$ & $\begin{array}{l}\text { - Flagpole area on the eastem edge of the } \\
\text { parade ground ringed with monuments and } \\
\text { memorials } \\
\text { - Iron Mike statue located in traffic circle at } \\
\text { the intersection of Armistead Street, Dyer } \\
\text { Street, and Adams Street }\end{array}$ \\
\hline
\end{tabular}




\section{Appendix B: Army's Standardized Planting Plans from 1933}

Figures B1- B4 show drawings of the Army's standardized planting plans from 1933. These plans should serve as a general guide for planting selection and design within the OPHD. 


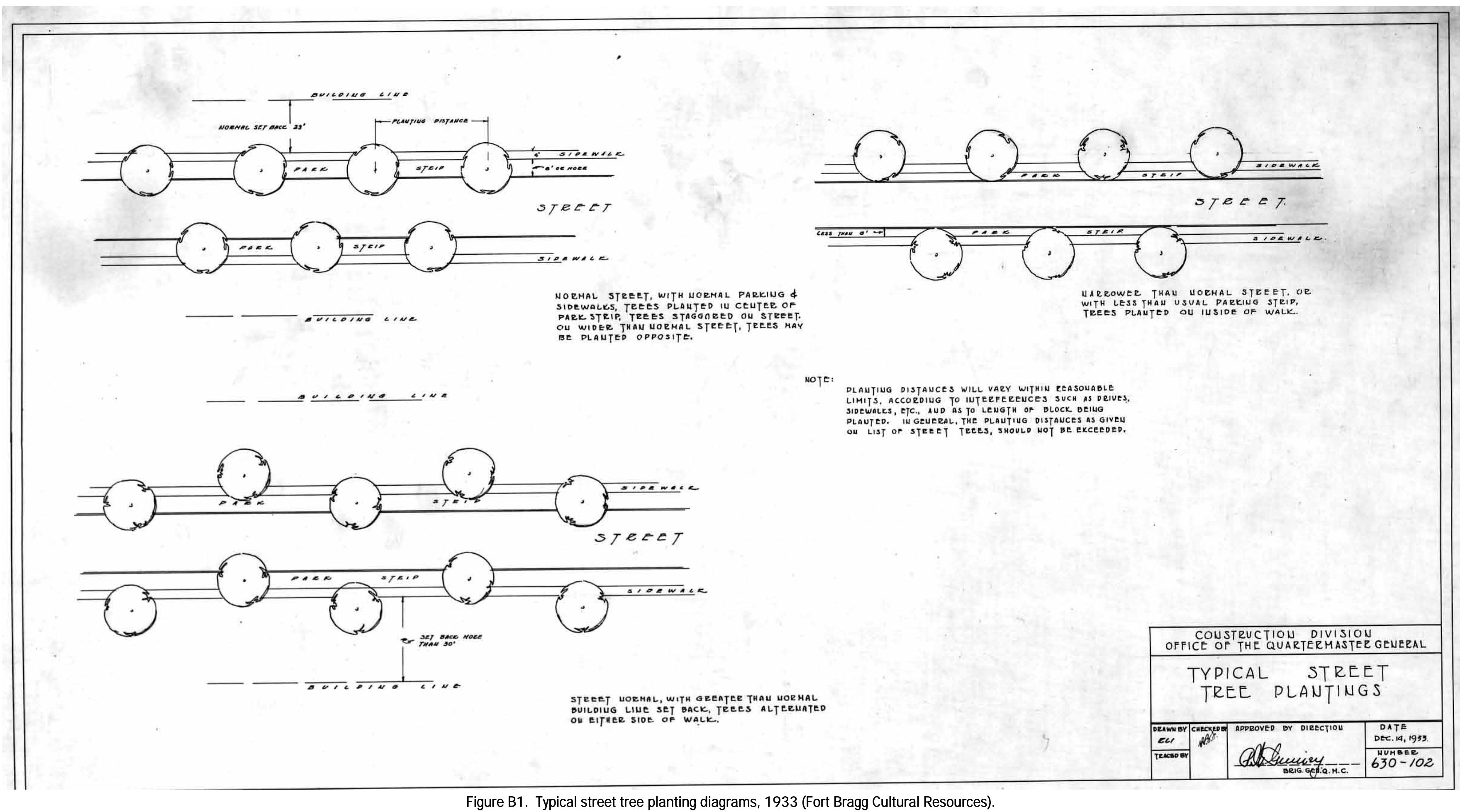

Figure B1. Typical street tree planting diagrams, 1933 (Fort Bragg Cultural Resources). 



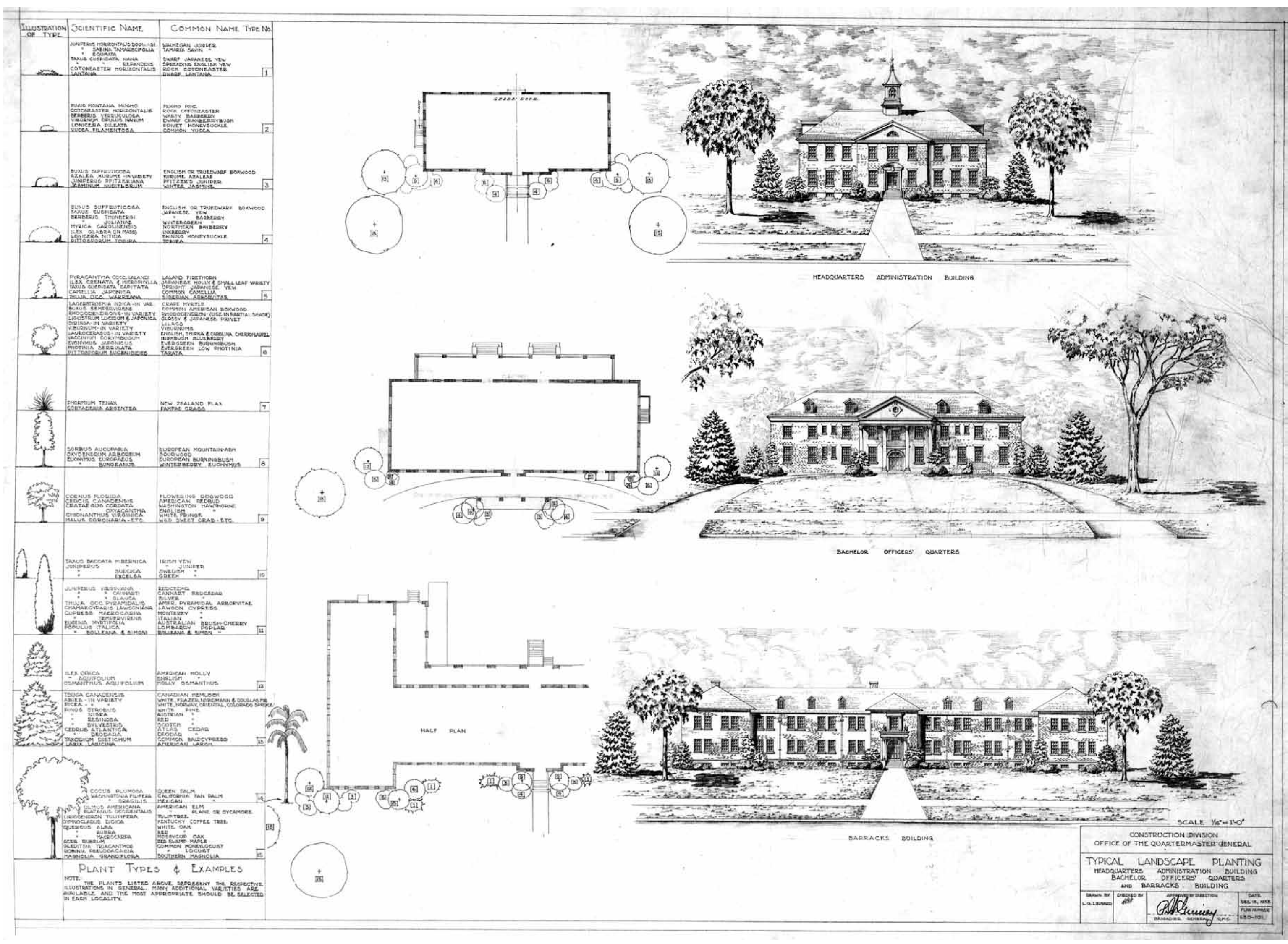

Figure B2. 1933 standardized planting plans for headquarters, BOQ, and barracks (Fort Bragg Cultural Resources). 


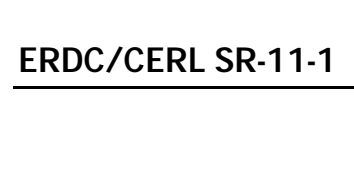




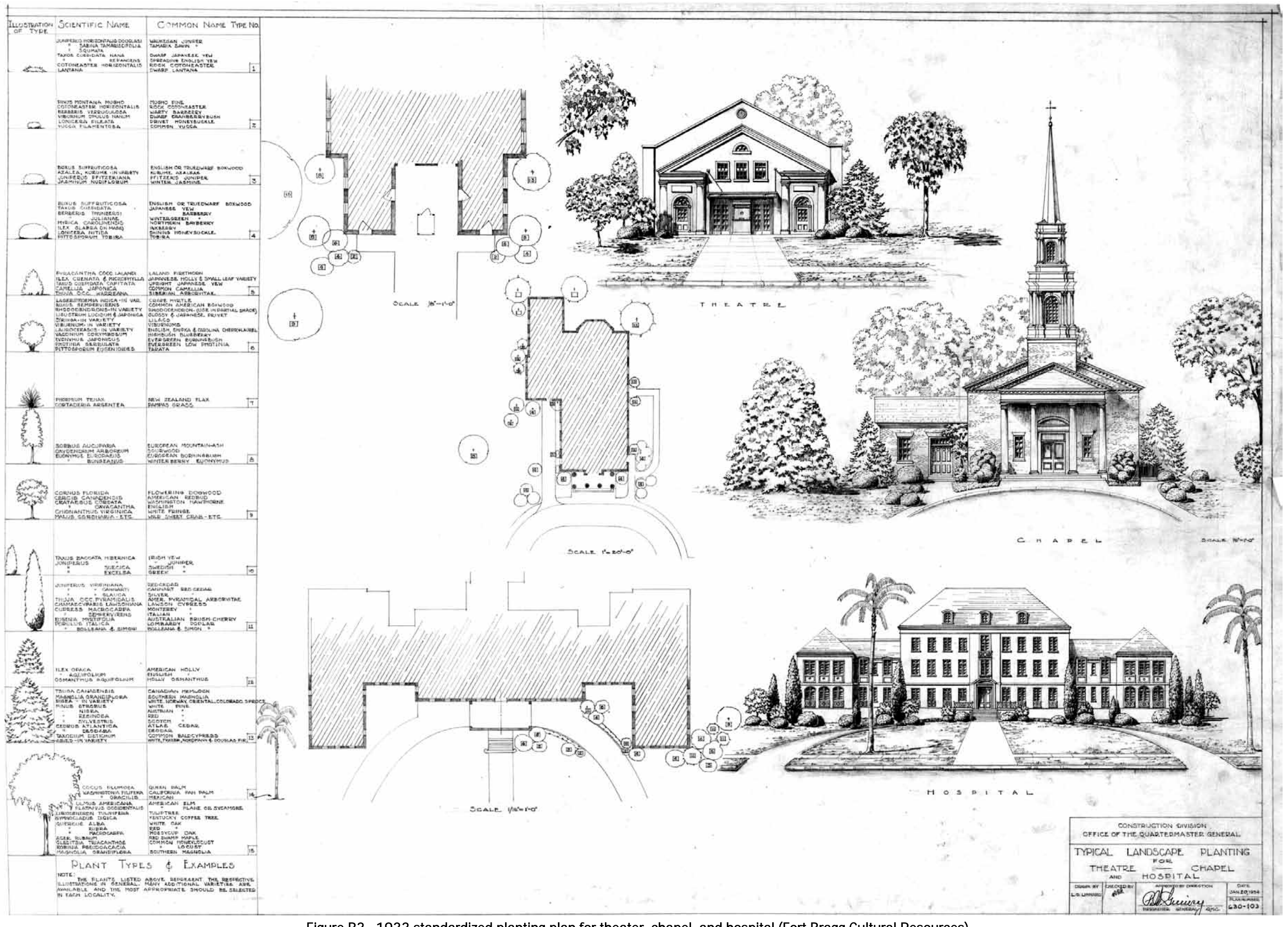

Figure B3. 1933 standardized planting plan for theater, chapel, and hospital (Fort Bragg Cultural Resources). 



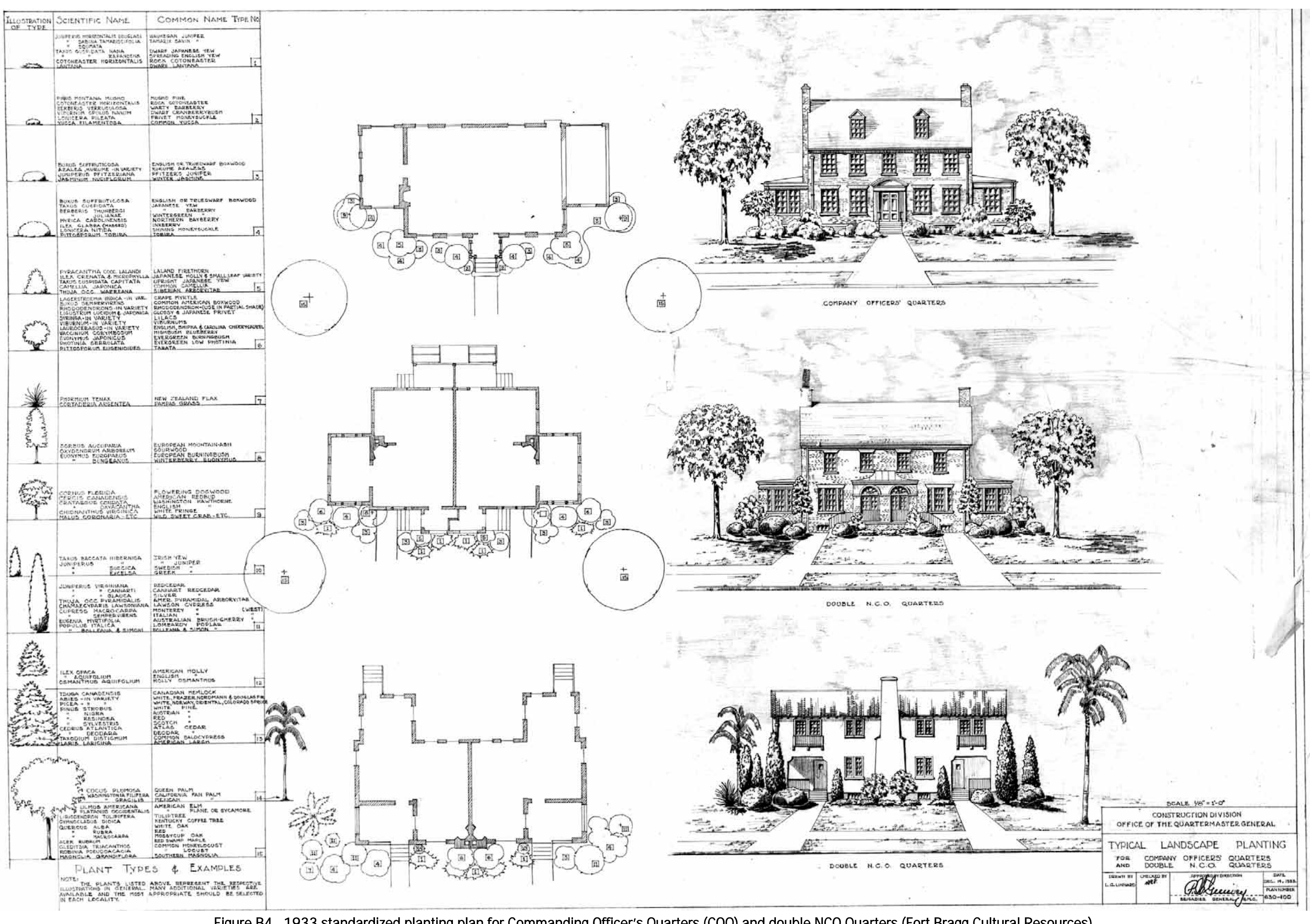

Figure B4. 1933 standardized planting plan for Commanding Officer's Quarters (COQ) and double NCO Quarters (Fort Bragg Cultural Resources). 



\section{Appendix C: Plant List Taken from the Army's 1933 Standardized Planting Plans}

Table C1 lists plants taken from the Army's 1933 standardized planting plans. As per the Army's list, the plants are sorted according to type. Table C1 specifies size, habit, and distinguishing characteristics. Noted in the left column are if the plants are native or invasive in the Fort Bragg region. Native and invasive plants are highlighted in green and red respectively, species without a designation are not native or regionally inappropriate. 
Table C1. Planting list from the Amys 1933 standardized planting plans (ERDC-CERL).

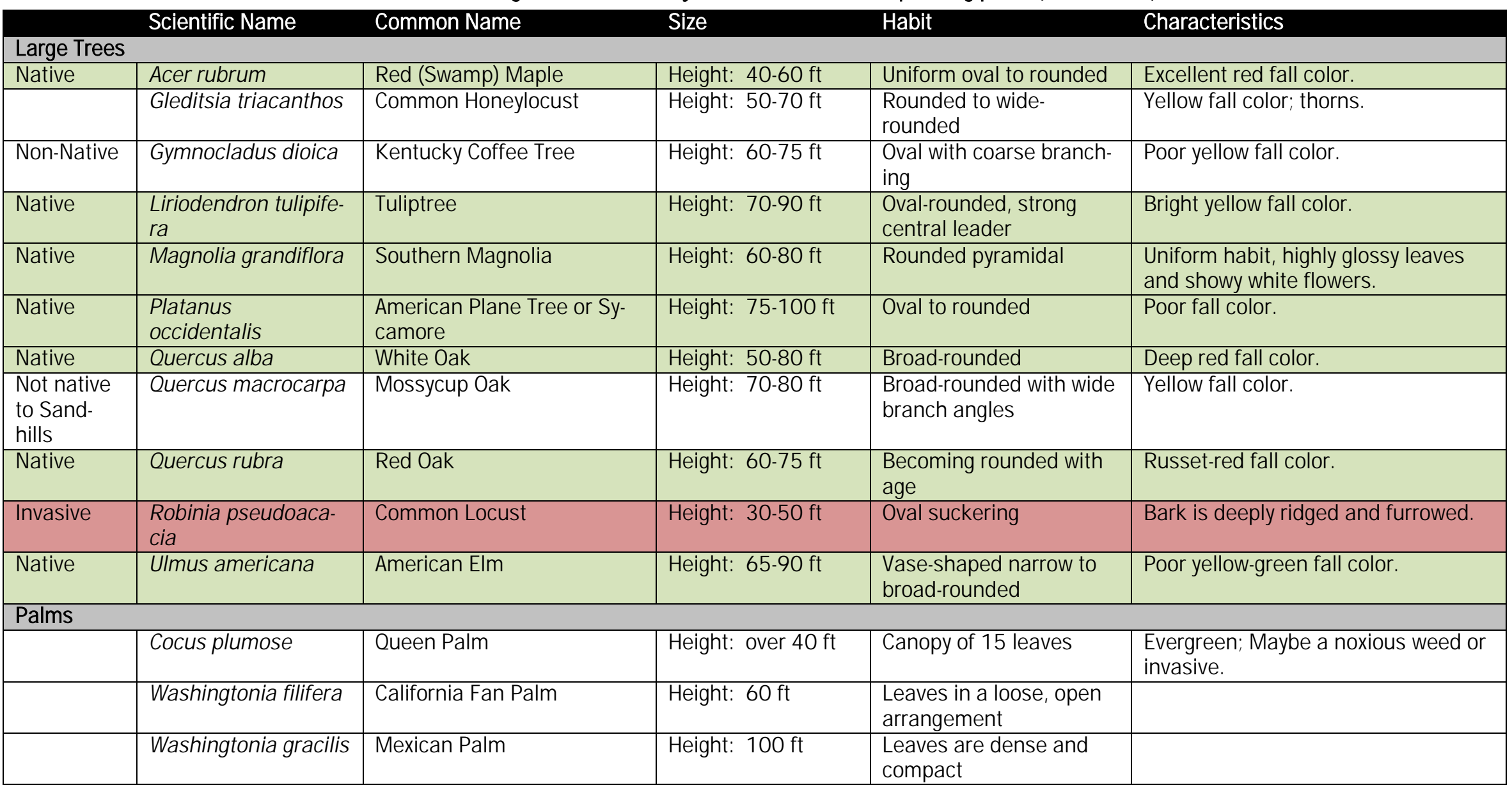




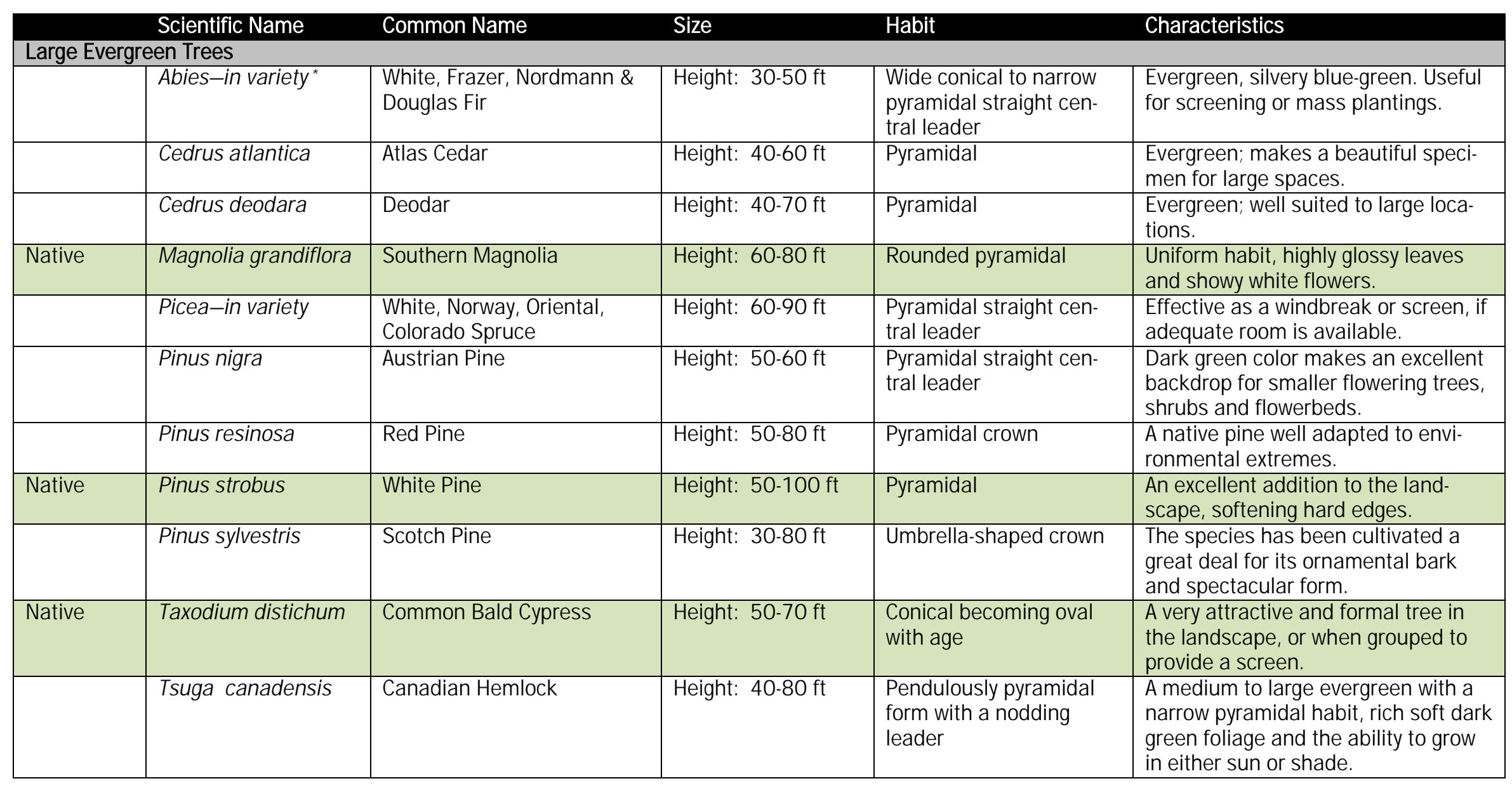

* In variety designates there are several varieties of the species that can be used. 


\begin{tabular}{|c|c|c|c|c|c|}
\hline \multirow{2}{*}{\multicolumn{2}{|c|}{$\begin{array}{l}\text { Scientific Name } \\
\text { Medium Everareen Trees }\end{array}$}} & Common Name & Size & \multirow{2}{*}{\multicolumn{2}{|c|}{ Characteristics }} \\
\hline & & & & \\
\hline & llex aquifolium & English Holly & Height: $15-50 \mathrm{ft}$ & $\begin{array}{l}\text { Dense pyramidal; heavily } \\
\text { branched }\end{array}$ & $\begin{array}{l}\text { Foliage is dense, dark-green leaves; } \\
\text { smooth and glossy with spines } \\
\text { around the edges. Berries are bright } \\
\text { red. }\end{array}$ \\
\hline \multirow[t]{2}{*}{ Native } & llex opaca & $\begin{array}{l}\text { American } \\
\text { Holly }\end{array}$ & Height: $20-40 \mathrm{ft}$ & Pyramidal habit & $\begin{array}{l}\text { A medium-sized evergreen tree with } \\
\text { a formal, pyramidal habit is often } \\
\text { grown for its foliage and persistent } \\
\text { red fruit. }\end{array}$ \\
\hline & $\begin{array}{l}\text { Osmanthus aquifo- } \\
\text { lium }\end{array}$ & Holly Osmanthus & Height: $4-6 \mathrm{ft}$ & shrubby habit & $\begin{array}{l}\text { Evergreen, similar characteristics as } \\
\text { llex. }\end{array}$ \\
\hline \multicolumn{6}{|c|}{ Large Evergreen Trees (columnar habit) } \\
\hline & $\begin{array}{l}\text { Chamaecyparis law- } \\
\text { soniana }\end{array}$ & Lawson Cypress & Height: $40-60 \mathrm{ft}$ & Columnar & $\begin{array}{l}\text { Evergreen foliage in flat sprays, } \\
\text { somewhat glacous blue-green. Not } \\
\text { well adapted to most landscapes. }\end{array}$ \\
\hline & Cypress macrocarpa & Monterey Cypress & Height: $70-90 \mathrm{ft}$ & $\begin{array}{l}\text { Narrow pyramidal } \\
\text { spreading with age }\end{array}$ & $\begin{array}{l}\text { Evergreen; only grown in the westem } \\
\text { states. }\end{array}$ \\
\hline & $\begin{array}{l}\text { Cypress sempervi- } \\
\text { rens }\end{array}$ & Italian Cypress & Height: $40-60 \mathrm{ft}$ & Narrow columnar & $\begin{array}{l}\text { Often used for framing around build- } \\
\text { ings, does not lend itself to residen- } \\
\text { tial landscapes. }\end{array}$ \\
\hline & Eugenia myrtifolia & Australian Brush-Cherry & Height: $15-20 \mathrm{ft}$ & Columnar & $\begin{array}{l}\text { Evergreen, the leaves will develop } \\
\text { red highlights. }\end{array}$ \\
\hline Native & Juniperus virginiana & $\begin{array}{l}\text { Cannart Eastern Red Cedar } \\
\text { (now Canaert Red Cedar) }\end{array}$ & Height: $40-50 \mathrm{ft}$ & $\begin{array}{l}\text { Pyramidal habit with ho- } \\
\text { rizontally spreading } \\
\text { branches }\end{array}$ & $\begin{array}{l}\text { Especially useful in windbreaks, shel- } \\
\text { ter belts, hedges, and mass plant- } \\
\text { ings. }\end{array}$ \\
\hline Native & $\begin{array}{l}\text { Juniperus virginiana } \\
\text { 'Canaertii' }\end{array}$ & Cannart Eastern Red Cedar & Height: $25-35 \mathrm{ft}$ & Compact and pyramidal & $\begin{array}{l}\text { Glossy dark green foliage displayed } \\
\text { in a very bunchy appearance and a } \\
\text { good light blue fruit display. }\end{array}$ \\
\hline \multirow[t]{2}{*}{ Native } & $\begin{array}{l}\text { Juniperus virginiana } \\
\text { 'Glauca' }\end{array}$ & Silver Eastem Red Cedar & Height: $25 \mathrm{ft}$ & $\begin{array}{l}\text { Columnar or narrow py- } \\
\text { ramidal }\end{array}$ & $\begin{array}{l}\text { Foliage emerges silver-blue, but } \\
\text { fades to blue-green. }\end{array}$ \\
\hline & $\begin{array}{l}\text { Populus bolleana \& } \\
\text { simony }\end{array}$ & Bolleana \& Simon Poplar & Height: $50-100 \mathrm{ft}$ & Columnar & $\begin{array}{l}\text { Short lived with a rapid growth rate, } \\
\text { may tum clear yellow in fall }\end{array}$ \\
\hline
\end{tabular}




\begin{tabular}{|c|c|c|c|c|c|}
\hline & Scientific Name & Common Name & Size & Habit & Characteristics \\
\hline & $\begin{array}{l}\text { Populus italic (now: } \\
\text { Populus nigra 'Itali- } \\
\text { ca') }\end{array}$ & Lombardy Poplar & Height: $60-90 \mathrm{ft}$ & $\begin{array}{l}\text { Narrow columnar with } \\
\text { very narrow fastigiate } \\
\text { branching }\end{array}$ & $\begin{array}{l}\text { Fast growth rate and short life span } \\
\text { due to its susceptibility to a canker } \\
\text { disease. }\end{array}$ \\
\hline & $\begin{array}{l}\text { Thuja occ. pyramida- } \\
\text { lis }\end{array}$ & $\begin{array}{l}\text { American Pyramidal Arboni- } \\
\text { tae }\end{array}$ & Height: $20-30 \mathrm{ft}$ & $\begin{array}{l}\text { Pyramidal, multiple lead- } \\
\text { ers, loose branching }\end{array}$ & $\begin{array}{l}\text { A common narrow pyramidal ever- } \\
\text { green with multiple leaders. }\end{array}$ \\
\hline \multicolumn{6}{|c|}{ Small/Medium Evergreen Trees (columnar habit) } \\
\hline & Juniperus excelsa & Greek J uniper & Height: $8-12 \mathrm{ft}$ & $\begin{array}{l}\text { Columnar to slightly py- } \\
\text { ramidal }\end{array}$ & $\begin{array}{l}\text { Dense, compact blue-green foliage. } \\
\text { Good for screening. }\end{array}$ \\
\hline & Juniperus hibernica & Irish Juniper & Height: $5-15 \mathrm{ft}$ & $\begin{array}{l}\text { Narrow column, broader } \\
\text { and conical with age }\end{array}$ & $\begin{array}{l}\text { Dense, bluish-green foliage; drought } \\
\text { tolerant. }\end{array}$ \\
\hline & Juniperus suecica & Swedish Juniper & Height: $15 \mathrm{ft}$ & Narrow column & $\begin{array}{l}\text { Fine textured foliage, light green with } \\
\text { silvery blue highlights. }\end{array}$ \\
\hline & $\begin{array}{l}\text { Taxus baccata hiber- } \\
\text { nica }\end{array}$ & Irish Yew & Height: $15 \mathrm{ft}$ & $\begin{array}{l}\text { Tight columnar becoming } \\
\text { egg-shaped with age }\end{array}$ & Dark green foliage in flat sprays. \\
\hline \multicolumn{6}{|c|}{ Omamental Trees } \\
\hline Native & $\begin{array}{l}\text { Cercis } \\
\text { canadensis }\end{array}$ & American Redbud & Height: $20-35 \mathrm{ft}$ & $\begin{array}{l}\text { Broad-rounded, flat- } \\
\text { topped }\end{array}$ & $\begin{array}{l}\text { A native tree grown for its attractive } \\
\text { magenta-pink flowers in April. }\end{array}$ \\
\hline Native & $\begin{array}{l}\text { Chionanthus } \\
\text { virginica }\end{array}$ & White Fringe & Height: $12-20 \mathrm{ft}$ & $\begin{array}{l}\text { Rounded to broad- } \\
\text { rounded shrub }\end{array}$ & $\begin{array}{l}\text { This large shrub or small tree pro- } \\
\text { duces fine, lacy white flowers in late } \\
\text { May to earlyJ une. }\end{array}$ \\
\hline Native & Comus florida & Flowering Dogwood & Height: $30-40 \mathrm{ft}$ & $\begin{array}{l}\text { Broad-rounded; horizon- } \\
\text { tal branches }\end{array}$ & $\begin{array}{l}\text { One of the best native flowering } \\
\text { trees, with ornamental characteris- } \\
\text { tics in all seasons. }\end{array}$ \\
\hline \multirow[t]{2}{*}{ Native } & $\begin{array}{l}\text { Crataegus cordata } \\
\text { (now: Crataegus } \\
\text { phaenopyrum) }\end{array}$ & Washington Hawthome & Height: $30 \mathrm{ft}$ & $\begin{array}{l}\text { Rounded, vase-shaped in } \\
\text { youth }\end{array}$ & $\begin{array}{l}\text { Excellent long-persisting red fruit } \\
\text { display, has good, foliage, flowers } \\
\text { and fall color. }\end{array}$ \\
\hline & $\begin{array}{l}\text { Crataegus oxyacan- } \\
\text { tha }\end{array}$ & English Hawthorne & Height: $15-25 \mathrm{ft}$ & $\begin{array}{l}\text { Rounded with ascending } \\
\text { branches, low branched, } \\
\text { shrubby }\end{array}$ & $\begin{array}{l}\text { Widely seen in Europe, this species is } \\
\text { little used in the U.S. because of its } \\
\text { susceptibility to a variety of disease } \\
\text { problems. The pink-flowered selec- } \\
\text { tions are used. }\end{array}$ \\
\hline
\end{tabular}




\begin{tabular}{|c|c|c|c|c|c|}
\hline & Scientific Name & Common Name & Size & Habit & Characteristics \\
\hline Native & $\begin{array}{l}\text { Malus } \\
\text { coronaria-etc. }\end{array}$ & Wild Sweet Crab-etc. & Height: $20-30 \mathrm{ft}$ & $\begin{array}{l}\text { Bushy shrub with rigid, } \\
\text { contorted branches }\end{array}$ & $\begin{array}{l}\text { Has white flowers tinged with pink. } \\
\text { Flowering time is two weeks later } \\
\text { than that of the domestic apple. }\end{array}$ \\
\hline \multicolumn{6}{|c|}{ Small Trees } \\
\hline & $\begin{array}{l}\text { Euonymus bungea- } \\
\text { nus }\end{array}$ & Winterberyy Euonymus & Height: $20-25 \mathrm{ft}$ & $\begin{array}{l}\text { Rounded small tree or } \\
\text { large shrub, pendulous } \\
\text { branches, loose, open }\end{array}$ & $\begin{array}{l}\text { Asmall Asian deciduous tree grown } \\
\text { for its attractive and persistent pin- } \\
\text { kish white capsules that mature in } \\
\text { fall. }\end{array}$ \\
\hline & $\begin{array}{l}\text { Euonymus euro- } \\
\text { paeus }\end{array}$ & European Bumingbush & Height: $20-30 \mathrm{ft}$ & $\begin{array}{l}\text { Oval to rounded large } \\
\text { shrub or small tree }\end{array}$ & $\begin{array}{l}\text { Excellent fall fruit display, this small } \\
\text { deciduous species produces pink to } \\
\text { red capsules with orange seeds. }\end{array}$ \\
\hline \multirow[t]{2}{*}{ Native } & $\begin{array}{l}\text { Oxydendrum arbo- } \\
\text { reum }\end{array}$ & Sourwood & Height: $25-30 \mathrm{ft}$ & $\begin{array}{l}\text { Pyramidal in youth be- } \\
\text { coming rounded- } \\
\text { pyramidal with drooping } \\
\text { branches }\end{array}$ & $\begin{array}{l}\text { Showy white flowers and excellent } \\
\text { fall color; species requires acidic } \\
\text { soils to survive. }\end{array}$ \\
\hline & Sorbus aucuparia & European Mountainash & Height: $20-40 \mathrm{ft}$ & $\begin{array}{l}\text { Oval to rounded- } \\
\text { pyramidal }\end{array}$ & $\begin{array}{l}\text { Dark green in summer, becoming } \\
\text { yellow to reddish in autumn. }\end{array}$ \\
\hline \multicolumn{6}{|c|}{ Decorative Grasses } \\
\hline & Cortaderia argentea & Pampas Grass & $\begin{array}{l}\text { Height: } 8 \mathrm{ft} \mathrm{high} \mathrm{x} \\
8 \mathrm{ft} \text { spread }\end{array}$ & & $\begin{array}{l}\text { Evergreen; produces flowers in au- } \\
\text { tumn can be used to screen. }\end{array}$ \\
\hline & Phormium tenax & New Zealand Flax & Height: $6 \mathrm{ft}-8 \mathrm{ft}$ & & Evergreen; smooth textured. \\
\hline \multicolumn{6}{|c|}{ Large Shrubs/ Small Trees (Rounded Habit) } \\
\hline & Buxus sempervirens & Common American Boxwood & Height: $15-20 \mathrm{ft}$ & $\begin{array}{l}\text { Dense, multi-branched } \\
\text { shrub }\end{array}$ & $\begin{array}{l}\text { Evergreen shrub with fine-textured } \\
\text { small leaves, mostly grown for its } \\
\text { foliage effects. }\end{array}$ \\
\hline & Euonymus japonicus & Evergreen Bumingbush & Height: $10-15 \mathrm{ft}$ & $\begin{array}{l}\text { Dense, oval mounded, } \\
\text { stiff }\end{array}$ & $\begin{array}{l}\text { Evergreen or variegated glossy } \\
\text { leaves with pale pink flowers. }\end{array}$ \\
\hline & Lagerstroemia indica & Crape Myrtle & Height: $3-30 \mathrm{ft}$ & $\begin{array}{l}\text { Multi-stemmed small } \\
\text { tree, small to large shrub }\end{array}$ & $\begin{array}{l}\text { Outstanding flowers, handsome bark, } \\
\text { and good fall color. }\end{array}$ \\
\hline Native & $\begin{array}{l}\text { Laurocerasus-in } \\
\text { variety }\end{array}$ & $\begin{array}{l}\text { English, Shipka \& Carolina } \\
\text { ChemyLaurel }\end{array}$ & Height: $6-10 \mathrm{ft}$ & $\begin{array}{l}\text { Broad-rounded large } \\
\text { shrub to small tree }\end{array}$ & $\begin{array}{l}\text { Dense with highly glossy dark green } \\
\text { foliage and fragrant white flowers. }\end{array}$ \\
\hline
\end{tabular}




\begin{tabular}{|c|c|c|c|c|c|}
\hline & Scientific Name & Common Name & Size & Habit & Characteristics \\
\hline \multirow[t]{3}{*}{ Invasive } & $\begin{array}{l}\text { Ligustrum lucidum \& } \\
\text { japonica }\end{array}$ & Glossy\& \&apanese Privet & Height: $25-30 \mathrm{ft}$ & Round, vase-shaped & $\begin{array}{l}\text { Can be grown in areas where air pol- } \\
\text { lution, poor drainage, compacted } \\
\text { soil, and drought are common. }\end{array}$ \\
\hline & Photinia semulata & Evergreen Low Photinia & Height: $15-20 \mathrm{ft}$ & Round, vase-shaped & $\begin{array}{l}\text { Has showy flowers and bright red } \\
\text { fruit. }\end{array}$ \\
\hline & $\begin{array}{l}\text { Pittosporum euge- } \\
\text { nioides }\end{array}$ & Tarata & Height: $20-30 \mathrm{ft}$ & Mounded shrub & $\begin{array}{l}\text { Has a strong lemony smell and at- } \\
\text { tractive, showy flowers. }\end{array}$ \\
\hline \multirow[t]{2}{*}{$\begin{array}{l}\text { Some Na- } \\
\text { tive }\end{array}$} & Rhododendrons & $\begin{array}{l}\text { Rhododendrons (Use in par- } \\
\text { tial shade) }\end{array}$ & Height: $3-10 \mathrm{ft}$ & Rounded & $\begin{array}{l}\text { Dark green foliage with showy flow- } \\
\text { ers. }\end{array}$ \\
\hline & Syringa-in variety & Lilacs & Height: $6-15 \mathrm{ft}$ & $\begin{array}{l}\text { Upright leggy, rounded } \\
\text { shrub, suckering heavily }\end{array}$ & $\begin{array}{l}\text { Very showy, fragrant flowers ranging } \\
\text { from white to pink to red to blue to } \\
\text { violet. }\end{array}$ \\
\hline $\begin{array}{l}\text { Some Na- } \\
\text { tive }\end{array}$ & $\begin{array}{l}\text { Vaccinium corymbo- } \\
\text { sum }\end{array}$ & Highbush Bluebery & Height: $6-12 \mathrm{ft}$ & $\begin{array}{l}\text { Rounded, multi- } \\
\text { stemmed, fairly uniform, } \\
\text { arching, leggy at base }\end{array}$ & $\begin{array}{l}\text { Produces blueberries, this medium to } \\
\text { large deciduous shrub has glossy } \\
\text { green foliage, interesting white flow- } \\
\text { ers and excellent fall color. }\end{array}$ \\
\hline Native & Vibumum - in variety & Vibumums & Height: $6-12 \mathrm{ft}$ & $\begin{array}{l}\text { Rounded, multi- } \\
\text { stemmed, upright } \\
\text { branching, arching }\end{array}$ & $\begin{array}{l}\text { Has showy cream white flowers and } \\
\text { attractive fall color. }\end{array}$ \\
\hline \multicolumn{6}{|c|}{ Large Shrubs/Small Trees (evergreen) } \\
\hline & Camellia japonica & Common Camellia & Height: $10-15 \mathrm{ft}$ & $\begin{array}{l}\text { Upright, dense pyramidal } \\
\text { shrub; stiff and formal }\end{array}$ & $\begin{array}{l}\text { Evergreen with showy flowers that } \\
\text { range from white to pink to red, to } \\
\text { rose, to variegated. }\end{array}$ \\
\hline & $\begin{array}{l}\text { Ilex crenata \& micro- } \\
\text { phylla }\end{array}$ & $\begin{array}{l}\text { Japanese Holly \& Small Leaf } \\
\text { Variety }\end{array}$ & Height: $5-10 \mathrm{ft}$ & $\begin{array}{l}\text { Pyramidal, most cultivars } \\
\text { rounded to broad- } \\
\text { rounded }\end{array}$ & $\begin{array}{l}\text { Fine-textured, small-leaved, medium- } \\
\text { sized evergreen shrub with black } \\
\text { fruit. }\end{array}$ \\
\hline & $\begin{array}{l}\text { Pyracantha cocc. } \\
\text { Lalandei }\end{array}$ & Laland Firethorn & Height: $8-15 \mathrm{ft}$ & $\begin{array}{l}\text { road-rounded with stiff } \\
\text { irregular branching }\end{array}$ & $\begin{array}{l}\text { An orange-red fruited selection with } \\
\text { greater cold hardiness than the spe- } \\
\text { cies. }\end{array}$ \\
\hline & $\begin{array}{l}\text { Taxus cuspidate ca- } \\
\text { pitata }\end{array}$ & Upright Japanese Yew & Height: $40-50 \mathrm{ft}$ & $\begin{array}{l}\text { Pyramidal, loose and } \\
\text { open }\end{array}$ & $\begin{array}{l}\text { It is commonly sheared into a tight } \\
\text { pyramidal habit. }\end{array}$ \\
\hline & Thuja occ. Wareana & Siberian Arborvitae & Height: $20-30 \mathrm{ft}$ & $\begin{array}{l}\text { Columnar; single or mul- } \\
\text { ti-trunked }\end{array}$ & Evergreen, low-maintenance plant. \\
\hline
\end{tabular}




\begin{tabular}{|c|c|c|c|c|c|}
\hline \multirow{3}{*}{ Large Shn } & \multirow{2}{*}{ Scientific Name } & \multirow[t]{2}{*}{ Common Name } & \multirow[t]{2}{*}{ Size } & \multirow[t]{2}{*}{ Habit } & \multirow[t]{2}{*}{ Characteristics } \\
\hline & & & & & \\
\hline & Berberis julianae & Wintergreen Barberry & Height: $6-10 \mathrm{ft}$ & $\begin{array}{l}\text { Rounded with somewhat } \\
\text { loose branching }\end{array}$ & $\begin{array}{l}\text { Good specimen, hedge, or barier, as } \\
\text { it is almost impenetrable due to its } \\
\text { long spines. }\end{array}$ \\
\hline \multirow[t]{2}{*}{ Invasive } & Berberis thunbergii & Japanese Barberry & Height: $3-6 \mathrm{ft}$ & $\begin{array}{l}\text { Broad rounded and } \\
\text { slightly cascading to } \\
\text { mounded }\end{array}$ & $\begin{array}{l}\text { Grown for its fine texture, ease of } \\
\text { cultivation and persistent red berries. }\end{array}$ \\
\hline & Buxus suffruticosa & $\begin{array}{l}\text { English or Truedwarf Box- } \\
\text { wood }\end{array}$ & Height: $4-5 \mathrm{ft}$ & $\begin{array}{l}\text { Broad rounded slightly } \\
\text { shrubby }\end{array}$ & $\begin{array}{l}\text { Dense and compact, slow growing. } \\
\text { Often used for edging. }\end{array}$ \\
\hline \multirow[t]{2}{*}{ Native } & Ilex glabra (in mass) & Inkberry & Height: $6-8 \mathrm{ft}$ & $\begin{array}{l}\text { Rounded, erect, open } \\
\text { and often leggy plant }\end{array}$ & $\begin{array}{l}\text { This medium, rounded shrub with } \\
\text { evergreen leaves and black fruit is } \\
\text { often cultivated for the foliage quality } \\
\text { of its dwarf forms. }\end{array}$ \\
\hline & Lonicera nitida & Shining Honeysuckle & Height: $6-8 \mathrm{ft}$ & Mounded pyramidal & $\begin{array}{l}\text { Evergreen dense, leafy, drought tole- } \\
\text { rant with beautiful foliage and crea- } \\
\text { my white flowers. }\end{array}$ \\
\hline \multirow[t]{3}{*}{ Native } & Morella carolinensis & Southem Bayberry & Height: $10 \mathrm{ft}$ & Upright rounded, & $\begin{array}{l}\text { Grows in full sun to moderate shade; } \\
\text { also resistant to drought, salt, soil } \\
\text { compaction and pests. }\end{array}$ \\
\hline & Pittosporum tobira & Tobira & Height: $8-12 \mathrm{ft}$ & $\begin{array}{l}\text { Dense broad spreading } \\
\text { mound }\end{array}$ & $\begin{array}{l}\text { Tough, durable plant with stiff } \\
\text { branches; creamy green flowers. }\end{array}$ \\
\hline & Taxus cuspidate & Japanese Yew & Height: $10-40 \mathrm{ft}$ & $\begin{array}{l}\text { Pyramidal to broad- } \\
\text { rounded }\end{array}$ & $\begin{array}{l}\text { A very dark green shrub to medium } \\
\text { tree with evergreen foliage. }\end{array}$ \\
\hline \multicolumn{6}{|c|}{ Medium Shrubs } \\
\hline & $\begin{array}{l}\text { Azalea kurume-in } \\
\text { variety }\end{array}$ & Kurume Azaleas & Height: $2-6 \mathrm{ft}$ & Broad twiggy branching & $\begin{array}{l}\text { Evergreen dwarf or semi-dwarf in size } \\
\text { with extremely dense foliage. Profuse } \\
\text { blooms in white, pink, red, or salmon. }\end{array}$ \\
\hline & Buxus suffruticosa & $\begin{array}{l}\text { English or Truedwarf Box- } \\
\text { wood }\end{array}$ & Height: $4-5 \mathrm{ft}$ & Broad rounded & $\begin{array}{l}\text { Dense and compact, slow growing. } \\
\text { Often used for edging. }\end{array}$ \\
\hline & $\begin{array}{l}\text { Jasminum nudiflo- } \\
\text { rum }\end{array}$ & Winter Jasmine & Height: $3-4 \mathrm{ft}$ & $\begin{array}{l}\text { Broad spreading arching } \\
\text { fine, willowy stems }\end{array}$ & $\begin{array}{l}\text { Tolerates a range of conditions in- } \\
\text { cluding heavy clay and sand, drought } \\
\text { tolerant. }\end{array}$ \\
\hline
\end{tabular}




\begin{tabular}{|c|c|c|c|c|c|}
\hline & Scientific Name & Common Name & Size & Habit & Characteristics \\
\hline & Juniperus pfitzeriana & Pfitzer's J uniper & Height: $10 \mathrm{ft}$ & $\begin{array}{l}\text { Wide-spreading } \\
\text { branches with drooping } \\
\text { tips }\end{array}$ & $\begin{array}{l}\text { Evergreen known for its broad- } \\
\text { rounded habit with horizontally tiered } \\
\text { bright green foliage. }\end{array}$ \\
\hline \multicolumn{6}{|c|}{ Small shrubs } \\
\hline & Berberis verruculosa & Warty Barberry & $\begin{array}{l}\text { Height: } 3-6 \mathrm{ft} \\
\text { by } 3-4 \mathrm{ft}\end{array}$ & $\begin{array}{l}\text { Compact, dense, } \\
\text { rounded }\end{array}$ & $\begin{array}{l}\text { Drought tolerant; dependable; easy } \\
\text { to transplant; can be used as speci- } \\
\text { men, hedge, or barrier plant; tole- } \\
\text { rates urban conditions. }\end{array}$ \\
\hline & $\begin{array}{l}\text { Cotoneaster horizon- } \\
\text { talis }\end{array}$ & Rock Cotoneaster & $\begin{array}{l}\text { Height: } 2-3 \mathrm{ft} \text {, } \\
\text { spreading to } 8 \mathrm{ft}\end{array}$ & $\begin{array}{l}\text { Horizontally spreading, } \\
\text { ascending branches }\end{array}$ & $\begin{array}{l}\text { Low-growing, flat-topped groundcover } \\
\text { with glossy dark green leaves and } \\
\text { bright red autumn fruit. }\end{array}$ \\
\hline & Lonicera pileata & Privet Honeysuckle & $\begin{array}{l}\text { Height: } 2-3 \mathrm{ft} \\
\text { by } 3-5 \mathrm{ft}\end{array}$ & $\begin{array}{l}\text { Low spreading horizontal } \\
\text { branches }\end{array}$ & $\begin{array}{l}\text { Evergreen, drought tolerant with yel- } \\
\text { low white flowers in early summer. }\end{array}$ \\
\hline & Pinus mugo & Mugo Pine & Height: $8-12 \mathrm{ft}$ & $\begin{array}{l}\text { Pyramidal to broad- } \\
\text { rounded }\end{array}$ & $\begin{array}{l}\text { Does not tolerate extreme heat, does } \\
\text { not perform well in the South. }\end{array}$ \\
\hline & $\begin{array}{l}\text { Vibumum opulus } \\
\text { Nanum }\end{array}$ & Dwarf Cranberrybush & Height: $2-3 \mathrm{ft}$ & Broad-rounded, compact & $\begin{array}{l}\text { Grown primarily for its foliage this } \\
\text { small shrub produces few to no flow- } \\
\text { ers or fruits. }\end{array}$ \\
\hline Native & Yucca filamentosa & $\begin{array}{l}\text { Adams Needle (Common } \\
\text { Yucca) }\end{array}$ & $\begin{array}{l}\text { Height: } 2.5 \mathrm{ft} \\
\text { by } 2.5 \mathrm{ft}\end{array}$ & Radiating clump & $\begin{array}{l}\text { A bold evergreen focal point in the } \\
\text { landscape, either in group plantings } \\
\text { or solitary, used at entranceways, } \\
\text { borders, rock gardens, island beds, } \\
\text { or as a specimen accent. }\end{array}$ \\
\hline \multicolumn{6}{|c|}{ Groundcovers } \\
\hline & Lantana & Dwarf Lantana & $\begin{array}{l}\text { Height: } 1 \mathrm{ft} \\
\text { by } 5 \mathrm{ft}\end{array}$ & Horizontally spreading & $\begin{array}{l}\text { Evergreen groundcover with showy } \\
\text { flowers in summer and autumn. }\end{array}$ \\
\hline & $\begin{array}{l}\text { Juniperus horizonta- } \\
\text { lis Douglasii }\end{array}$ & Waukegan J uniper & $\begin{array}{l}\text { Height: } 1-1.5 \mathrm{ft} \\
\text { by } 6-10 \mathrm{ft}\end{array}$ & Horizontally spreading & $\begin{array}{l}\text { Evergreen. Steel blue foliage turns } \\
\text { gray-purple in winter; leaves are scaly } \\
\text { and needle-like. Rapid grower, mat- } \\
\text { like habit. }\end{array}$ \\
\hline & $\begin{array}{l}\text { Juniperus sabina var. } \\
\text { tamariscifolia }\end{array}$ & Tamariscifolia Savin J uniper & $\begin{array}{l}\text { Height: } 1.5 \mathrm{ft} \\
\text { by } 10-15 \mathrm{ft}\end{array}$ & Low mounded & $\begin{array}{l}\text { Horizontal branches and short, } \\
\text { spreading branchlets. }\end{array}$ \\
\hline
\end{tabular}




\begin{tabular}{|c|c|c|c|c|c|}
\hline & Scientific Name & Common Name & Size & Habit & Characteristics \\
\hline & Juniperus squamata & Singleseed J uniper & Height: 2-15 ft & $\begin{array}{l}\text { Wide-spreading decum- } \\
\text { bent }\end{array}$ & $\begin{array}{l}\text { Evergreen; grayish-green to bright } \\
\text { blue-green. }\end{array}$ \\
\hline & $\begin{array}{l}\text { Taxus cuspidata } \\
\text { 'Nana' }\end{array}$ & Dwarf Japanese Yew & Height: $10-15 \mathrm{ft}$ & Broad-rounded & $\begin{array}{l}\text { A slow-growing "dwarf" variety that } \\
\text { often gets larger than dwarf. }\end{array}$ \\
\hline & $\begin{array}{l}\text { Taxus cuspidate Re- } \\
\text { pandens }\end{array}$ & Repandens English Yew & Height: $3 \mathrm{ft}$ & Very broad-rounded & $\begin{array}{l}\text { A low-growing very broad-rounded } \\
\text { dark evergreen shrub with pendulous } \\
\text { branch tips and greater cold hardi- } \\
\text { ness. }\end{array}$ \\
\hline
\end{tabular}




\section{Appendix D: Appropriate and Inappropriate Plants for Fort Bragg}

Tables D1- D3 supplement the Army's 1933 standardized planting list with current lists of appropriate and inappropriate plants for Fort Bragg. The Installation Design Guidelines (IDG) Practical Plantings table lists plants that have been approved for use by Fort Bragg's Arbor Board. The second table is a list of plants native to North Carolina and should be used as a general guide when choosing plants not specified on the Army's 1933 standardized planting plan or the IDG Practical Plantings list. The third table lists plants never to be planted at Fort Bragg. These plants have been classified as moderately to highly invasive and, even if historical, appropriate substitutes should be used. 


\section{Installation Design Guidelines (IDG) Practical Plantings}

Table D1. Fort Bragg's IDG Practical Plantings list, December 2009 (Installation Design Guide for a Sustainable Fort Bragg).

\begin{tabular}{|c|c|c|c|c|c|c|c|c|c|c|c|c|c|c|c|c|c|c|c|c|c|c|c|c|}
\hline \multicolumn{3}{|c|}{ IDG Practical Plantings } & \multicolumn{2}{|l|}{ 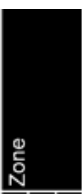 } & \multicolumn{2}{|c|}{ 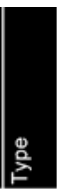 } & \multicolumn{3}{|c|}{ 들 } & \multicolumn{3}{|c|}{$\frac{\overrightarrow{5}}{\underline{\Xi}}$} & \multicolumn{2}{|c|}{ 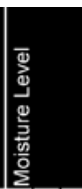 } & \multicolumn{3}{|c|}{$\begin{array}{l}\frac{\bar{o}}{0} \\
0 \\
\overline{\mathrm{E}} \\
\frac{\mathrm{o}}{\mathrm{O}} \\
\end{array}$} & & 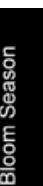 & & 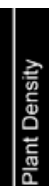 & & & 蔗 \\
\hline D\# & Common Name & Eientific Name & & & & & & & & & & & & & & & 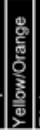 & & & 产 & & & & \\
\hline & Tall Trees & $>20^{\prime}$ Tall & & & & & & & & & & & & & & & & & & & & & & \\
\hline TT01 & American holly & llex opaca & $\cdot$ & $\cdot$ & & & $\cdot$ & $\cdot$ & I & & $\cdot$ & & - & & - & & & & - & - & & $\cdot$ & & \\
\hline TT02 & Atlantic white cedar & Chamaecyparis thyoides & $\cdot$ & $\cdot$ & & & - & $\cdot$ & of & & $\cdot$ & & $\cdot$ & & & & & & & $\cdot$ & $\cdot$ & $\cdot$ & $\cdot$ & \\
\hline TT03 & Darlington oak & Quercus laurifolia & - & -. & & 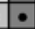 & - & $\cdot \mid$ & & & $\cdot$ & & - & $\bullet$ & & & & & • & $\cdot$ & & - & $\cdot$ & \\
\hline TT04 & Live oak & Quercus virginiana & & $\cdot$. & & & . & $\cdot$ & & & . & & • & †. & & & & & $\bullet$ & $\cdot$ & & $\bullet$ & & \\
\hline$\pi T 05$ & Longleaf pine & Pinus palustris & $\cdot$ & -. & & & $\cdot$ & - & & & $\cdot$ & & $\bullet$ & $\bullet$ & & & & & - & . & $\cdot$ & $\cdot$ & $\cdot$ & \\
\hline TT06 & Red maple & Acer rubrum & $\cdot$ & $\cdot 0$ & & & $\cdot$ & $\cdot$ & & & $\cdot$ & & & & & & & & $\bullet$ & & t & $\cdot$ & & \\
\hline TT07 & Southern magnolia & Magnolia grandiflora & $\cdot$ & -. & & & - & $\cdot$ & & & & & 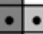 & & $\cdot$ & & & & $\cdot$ & - & $\cdot$ & - & & \\
\hline Tт08 & Tulip poplar & Liriodendron tulipifera & $\cdot \cdot$ & •. & & $\bullet$ & . & $\cdot$ & & & . & & • & & & & & & $\bullet$ & $\cdot$ & & $\cdot$ & .1 & \\
\hline TT09 & White oak & Quercus alba & - & $\cdot$ & & - & $\cdot$ & $\cdot$ & & & $\cdot$ & & - & $\bullet$ & & & & & - & $\bullet$ & $\cdot$ & - & $\cdot$ & \\
\hline$\pi$ T10 & Willow oak & Quercus phellos & & •. & & & 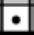 & & & & & & & & & & & & & & & & & \\
\hline & Small Trees & $8^{\prime}$ to $20^{\circ}$ Tall & & & & & & & & & & & & & & & & & & & & & & \\
\hline ST01 & Chickasaw plum & Prunus angustifolia & - & -. & & - & $\cdot$ & $\cdot 1$ & & & • & & & & $\bullet$ & & & & & & & - & & \\
\hline STO2 & Crepe myrtle* & Lagerstroemia indica & & & & - & $\cdot$ & - & 7 & & $\cdot$ & & & $\cdot$ & $\cdot$ & & & $\cdot$ & $\bullet$ & & - & $\cdot \bullet \cdot$ & $\cdot$ & - \\
\hline STO3 & Chokeberry & Sorbus arbutifolia & $\cdot$ & -. & & $\bullet$ & - & - 1 & & & • & $\cdot$ & $\cdot$ & & $\cdot$ & & & -. & - & $\bullet$ & $\cdot$ & $\cdot \cdot$ & & \\
\hline STO4 & Dogwood & \begin{tabular}{|l|} 
Cornus florida \\
\end{tabular} & $\cdot$ & •. & & • & . & - & t & 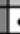 & . & $\cdot$ & • & •. & $\bullet$ & & & - & $\cdot$ & & $\cdot$ & $\cdot$ & & \\
\hline STO5 & Easter red cedar & Juniperus virginiana & $\cdot$ & $\cdot$ & & & . & $\cdot$ & if & & $\cdot$ & & $\bullet$ & $\bullet$ & & & & & - & $\bullet$ & & $\cdot$ & $\cdot-1$ & $\bullet$ \\
\hline ST06 & Juneberry & Amelenchier candensis & & •. & & $\bullet$ & . & & & & . & & • & & & & & & $\cdot$ & & $\bullet$ & $\bullet$ & & \\
\hline ST07 & \begin{tabular}{|l} 
Persimmon \\
\end{tabular} & Diospyros virginiana & $\cdot$ & $\cdot$ & & $\cdot$ & $\cdot$ & $\cdot$ & & 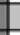 & • & $\bullet$ & - & $\cdot$ & & & $\cdot$ & $\cdot \cdot$ & $\cdot$ & - & $\cdot$ & - & & \\
\hline ST08 & \begin{tabular}{|l} 
Redbud \\
\end{tabular} & Cercis canadensis & $\cdot$ & •. & & & . & & & & . & & - & & & & & & & & - & • & & \\
\hline STO9 & Sassafras & Sassafras albidum & $\cdot$ & $\cdot$ & & $\bullet$ & $\bullet$ & & & to & . & & $\bullet$ & & - & & & $\cdot$ & $\bullet$ & & $\cdot$ & $\cdot$ & & \\
\hline ST10 & Sourwood & Oxydendrum arboreum & $\cdot$ & •. & & & $\cdot$ & & & & & - & - & & - & & & & - & & & - & & \\
\hline ST11 & Yaupon tree & llex vomitoria & $\cdot$ & $\cdot 0$ & I & & $\bullet$ & - & & A & . & & - & & & & & & & - & - 1 & $\cdot$ & & \\
\hline & Large Shrub & $4^{\prime}$ to $8^{\prime}$ Tall & & & & & & & & & & & & & & & & & & & & & & \\
\hline LS01 & Camellia* & Camellia japonica & & -. & & & & & & The & & & & & & & & -1 & & & & & & \\
\hline LS02 & Kalmia & Kalmia latifolia & $\cdot$ & $\cdot$. & & & $\bullet$ & $\cdot$ & & & † & & - & & $\bullet$ & & & $\cdot$. & - & $\cdot$ & $\cdot$ & $\bullet$ & $\cdot$ & $\bullet$ \\
\hline $\mathrm{LS} 03$ & Oakleaf hydrangea & Hydrangea quercifolia & $\cdot$ & . & & †. &. & & & & & $\cdot$ & & t. & - & & & & & & - & & - & - \\
\hline LSO4 & $\begin{array}{l}\text { Redbay } \\
\end{array}$ & Persea borbonia & & $\cdot$ & & & $\bullet$ & $\cdot$ & & & $\bullet$ & & - & & $\bullet$ & & & & $\bullet$ & & $\cdot$ & $\cdot$ & $\cdot$ & $\bullet$ \\
\hline LS05 & Rhododendron & Rhododendron spp. & $\cdot$ & -. & & & $\cdot$ & & & to & 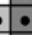 & & - & & $\cdot$ & & & - 1 & & • & - & - & $\cdot$ & $\bullet$ \\
\hline LS06 & Rose of sharon* & Hibiscus syriacus & $\cdot$ & $\cdot$ & & & $\bullet$ & & t & & - & & & & $\bullet$ & . & & •. & • & & $\cdot$ & & $\cdot$ & $\bullet$ \\
\hline LS07 & Serviceberry & Amelanchier arborea & $\cdot$ & -. & & & - & $\cdot$ & & is & $\cdot$ & & & & $\bullet$ & & & & - & & $\cdot$ & & $\cdot$ & $\bullet$ \\
\hline LS08 & Wax myrtle & Myrica cerifera & - & -. & & & $\bullet$ & & & & & & & & & & & & & & $\bullet$ & & $\cdot$ & $\bullet$ \\
\hline & Medium Shrub & $2^{\prime}$ to $4^{\prime}$ Tall & & & & & & & & & & & & & & & & & & & & & & \\
\hline MS01 & Acuba variegated ${ }^{*}$ & Acuba spp. & & & & & - & & & & & & & & - & & & & & & & & $\cdot$ & $\bullet$ \\
\hline $\mathrm{MSO2}$ & Azalea* & Rhododendron spp. & & $\cdot \cdot$ & & & $\cdot$ & & & & & $\cdot$ & & $\bullet$ & $\bullet$ & s & & $\cdot$ & $\cdot \bullet$ & & $\cdot$ & & $\cdot$ & $\bullet$ \\
\hline $\mathrm{MSO3}$ & Gardenia* & Gardenia spp. & & -. & & & $\cdot$ & & & & & $\cdot$ & - & 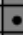 & - & & & & & & - & & $\cdot$ & $\bullet$ \\
\hline MS04 & Strawberry bush & Euonymus americanus & $\cdot$ & $\cdot 0$ & & & $\bullet$ & & & & & & $\bullet$ & & & & & & $\bullet$ & $\bullet$ & $\cdot$ & & $\cdot$ & $\bullet$ \\
\hline MSO5 & Sweet pepperbush & Clethra alnifolia & $\cdot$ & •. & & & $\bullet$ & & & & $\cdot$ & & - & & $\bullet$ & & & & & & - & & $\cdot$ & $\bullet$ \\
\hline & Small Shrub & $0^{\prime}$ to $2^{\prime}$ Tall & & & & & & & & & & & & & & & & & & & & & & \\
\hline SS01 & Azalea evergreen* & Rhododendron spp. & & $\bullet$ & & & $\bullet$ & & & I & & & - & & • & & & $\cdot$ & & $\bullet$ & $\bullet$ & & $\bullet$ & - \\
\hline SSO2 & Big Hosta* & Hosta lancifolia & & .. & & & 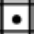 & $\cdot$ & & & $\bullet$ & & - & & & & & & & & - & & $\cdot$ & $\bullet$ \\
\hline $\mathrm{SSO3}$ & Dwarf Gardenia* & Gardenia spp. & & -. & & & $\cdot$ & & & & • & & - & 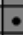 & - & & & & & & $\cdot$ & & $\cdot$ & $\bullet$ \\
\hline SSO4 & Dwarf Nandina* & Nandina domestica & & $\cdot$. & & & $\bullet$ & & t & & & & - & & & & & & & & & & $\cdot$ & \\
\hline SSO5 & Dwarf Yaupon & Ilex vomitoria 'Nana' & $\cdot$ & $\cdot$ & & & $\bullet$ & & & to & . & & - & & & & & & $\cdot$ & $\cdot$ & $\bullet$ & & $\cdot$ & $\bullet$ \\
\hline SSO6 & Hawthorne & Crataegus spp. & $\cdot$ & . & & & $\bullet$ & & ot & & . & & - & & $\bullet$ & & & & • & & - & & $\cdot$ & 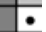 \\
\hline SS07 & Little Bluestem & Andropogon scoparius & - & $\cdot$ & & & - & & & & & & & $\bullet$ & & & & & $\bullet$ & $\bullet$ & & & & \\
\hline $\mathrm{SSOB}$ & Purple Muhly grass & Muhlenbergia capillaris & & & & & & & & & & & & & & & & & & & • & & & \\
\hline & Groundcover & $<1^{\prime}$ Tall & & & & & & & & & & & & & & & & & & & & & & \\
\hline $\mathrm{GCO1}$ & Ajuga* & Ajuga reptans & & & & & $\bullet$ & & & & $\bullet$ & & & & & & & & • & & & & & - \\
\hline $\mathrm{GCO} 2$ & Brachen Fern & Pteridum aquilinum & $\cdot \mid$ & . & & & & & & 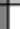 & $\bullet$ & $\bullet$ & • & & • & & & & & $\bullet$ & - & & & \\
\hline $\mathrm{GC} 03$ & Dwarf Huckleberry & Gaylussacia dumosa & $\cdot$ & -. & & & $\cdot$ & & & & . & & & †. & - & & & & $\bullet$ & & - & & $\cdot$ & - \\
\hline $\mathrm{GCO} 4$ & Dwarf Iris & Iris verna & $\cdot$ & -. & & - & - & & & 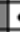 & & & & & $\cdot$ & & & & - & & $\cdot$ & & & . \\
\hline GCO5 & Liriope* & Liriope spp. & & •. & & & $\bullet$ & $\bullet$ & & & $\bullet$ & & & • & $\cdot$ & 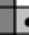 & & & & & $\cdot$ & & & - \\
\hline $\mathrm{GCO6}$ & Periwinkle spp." & Vinca major & $\cdot$ & $\cdot$ & & I & $\bullet$ & & & t. & $\bullet$ & & - & & $\bullet$ & 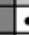 & & $\cdot$. & & & $\cdot$ & & $\cdot$ & • \\
\hline $\mathrm{GCO}$ & Periwinkle spp." & Vinca minor & & & & $\bullet$ & $\bullet$ & & & - & 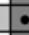 & & - & & & . & & & $\cdot$ & & - & & & $\cdot$ \\
\hline $\mathrm{GCOB}$ & Phlox & Phlox spp. & & & & & $\bullet$ & & & & $\bullet$ & & - & & $\bullet$ & & & & $\cdot$ & & & & $\cdot$ & - \\
\hline GCO9 & Well's delight & Vaccinium crassifolium & $\cdot$ & $\cdot \cdot$ & & & $\bullet$ & & & & & & 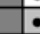 & & - & & & & •. & & 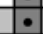 & & $\cdot$ & - \\
\hline GC10 & Wiregrass & Aristida stricta & $\cdot$ & & & & & & & & & & & & & & & & & & & & & \\
\hline
\end{tabular}




\section{Plants Native to North Carolina}

Table D2. Plants native to North Carolina with their culture requirements, 2002 (Moorman, et al. Landscaping for Wildlife with Native Plants).

\begin{tabular}{|c|c|c|c|c|c|c|c|c|c|}
\hline Latin Name & Common Name ${ }^{* t}$ & SoillLight & Region & $\begin{array}{l}\text { Wildlife } \\
\text { Value }\end{array}$ & Latin Name & Common Name ${ }^{* *}$ & Soil/Light & Region & $\begin{array}{l}\text { Wildlife } \\
\text { Value }\end{array}$ \\
\hline \multicolumn{5}{|c|}{ Tall trees (more than $30 \mathrm{ft}$ ) } & Alnus sernulata & Alder & W-MF-P & $M, P, C P$ & $S, L$ \\
\hline Acer barbatum & Southem Sugar Maple & MF-S & $P, C P$ & s & Amelanchier arborea & Serviceberry & M-D/F-S & $M, P$ & $F, N, L$ \\
\hline Acer rubrum & Red Maple & W-DiF-P & $\mathrm{M}_{1} \mathrm{P}_{\mathrm{C}} \mathrm{CP}$ & s & Amelanchier canadensis & Junebery & W-D/F-P & $P, C P$ & F,N L \\
\hline Acer saccharum & Sugar Maple & MF-S & M & s & Amelanchier laevis & Allegheny Serviceberry & M-DIF-P & M & $F, N, L$ \\
\hline Aescuits flava & Yellow Buckeye & MP-S & M & H & Aralia spinosa & Devil's Walking Stick & M/F-P & $M, P, C P$ & $\mathrm{~F}, \mathrm{~N}$ \\
\hline Betula lenta & Sweet Birch & M-D/F-S & M & $S, L$ & Asimina triloba & Pawpaw & MF-S & $\mathrm{M}, \mathrm{P}_{1} \mathrm{CP}$ & $F, L$ \\
\hline Betula nigra & River Birch & W-D/F & $P, C P$ & $S, L$ & Carpinus caroliniana & Ironwood & W-M/P-S & M,P,CP & $S, L$ \\
\hline Carya glabra & Pignut Hickory & DiF-S & $\mathrm{M}_{1} \mathrm{P}_{\mathrm{C}} \mathrm{CP}$ & $\mathrm{S}, \mathrm{L}$ & Castanea pumila & Chinquapin & D/F-P & $M, P, C P$ & $\mathrm{~s}$ \\
\hline Carya ovata & Shagbark Hickory & M-D/F-S & $M, P, C P$ & $S, L$ & Celtis tenuffolia & Dwarf Hackberry & DIF-P & $\mathrm{P}$ & $\mathrm{F}, \mathrm{L}$ \\
\hline Carya tomentosa & Mockernut Hickory & D/F-S & $M, P, C P$ & $S, L$ & Cercis canadensis & Eastern Redbud & $M-D / F-P$ & $M, P$ & $\mathrm{~S}, \mathrm{~N}, \mathrm{~L}$ \\
\hline Celtis laevigata & Sugarberry & MF-S & $P, C P$ & $\mathrm{~F}, \mathrm{~L}$ & Chionanthus virginicus & Fringetree & M-D/F-P & $M, P, C P$ & $\mathrm{~F}$ \\
\hline Chamaecyparis thyoides & Atlantic Whitecedar & W-MF-P & $\mathrm{CP}$ & $C, L$ & Comus amomum & Silky Dogwood & W-M/P-S & $M, P, C P$ & $F, N, L$ \\
\hline Diospyros virginiana & Persimmon & $M-D / F-P$ & $\mathrm{M}, \mathrm{P}, \mathrm{CP}$ & $\mathrm{F}$ & Comus florida & Flowering Dogwood & $M-D / F-P$ & $M, P, C P$ & $\mathrm{~F}, N_{t} \mathrm{~L}$ \\
\hline Fagus grandifiolia & American Beech & MP-S & $M_{1} P_{1} C P$ & $\mathrm{~s}$ & Crataegus spp. & Hawthom & M/F-S & $M, P, C P$ & $\mathrm{~F}, \mathrm{H}, \mathrm{N}, \mathrm{L}$ \\
\hline Fraxinus americana & White Ash & MF-S & $M, P$ & $\mathrm{~S}, \mathrm{~L}$ & Cynilla racemiflora & Titi & W-MF-S & $\mathrm{P}, \mathrm{CP}$ & $\mathrm{C}, \mathrm{N}$ \\
\hline Fraxinus pennsylvanica & Green Ash & W-D/F-P & $M, P, C P$ & $S, L$ & Halesia tetraptera & Carolina Silverbell & MP-S & $M, P$ & $\mathrm{~N}$ \\
\hline Gordonia lasianthus & Loblolly Bay & W-MF-P & $\mathrm{CP}$ & C & Hamamelis virginiana & Witch-Hazel & MF-S & M.P.CP & s \\
\hline llex ораса & American Holly & W-DIF-S & $\mathrm{M}, \mathrm{P}, \mathrm{CP}$ & $C, F, N, L$ & llex decidua & Possumhaw & W-DIF-P & $P, C P$ & $\mathrm{~F}, \mathrm{~N}, \mathrm{~L}$ \\
\hline Junipens virginiana & Eastem Redcedar & $M-D / F-P$ & $\mathrm{M}, \mathrm{P}, \mathrm{CP}$ & $\mathrm{C}, \mathrm{F}, \mathrm{L}$ & Ilex verticiliata & Winterberny & W-MF-S & M,P,CP & $F, N, L$ \\
\hline Liquidambar styracifiua & Sweetgum & W-MFF-P & $\mathrm{M}, \mathrm{P}, \mathrm{CP}$ & s & llex vomitoria & Yaupon & W-D/F-S & $\mathrm{CP}$ & $\mathrm{C}, \mathrm{F}, \mathrm{N}, \mathrm{L}$ \\
\hline Linodendron tulipifera & Yellow Poplar & MF-P & $M, P, C P$ & $\mathrm{~S}, \mathrm{H}, \mathrm{N}, \mathrm{L}$ & Morus rubra & Red Mulberry & M-DIF-S & $M, P, C P$ & $F, L$ \\
\hline Magnolia acuminata & Cucumber Tree & MF-P & MP & $\mathrm{S}$ & Myrica cerifera & Wax Myrtle & W-D/F-P & $\mathrm{P}, \mathrm{CP}$ & $C, F, L$ \\
\hline Magnolia grandifiora & Southem Magnolia & MP-S & $P, C P$ & $\mathrm{C}, \mathrm{S}$ & Osmanthus americana & Wild Olive, Devilwood & $M-D / F-P$ & $\mathrm{CP}$ & $\mathrm{C}, \mathrm{F}$ \\
\hline Magnolia virginiana & Sweethay & W-MF-P & $\mathrm{P}, \mathrm{CP}$ & $S, L$ & Ostrya virginiana & Hophombeam & M-D/F-S & $M, P$ & $F, L$ \\
\hline Nyssa sylvatica & Blackgum & D/F-P & $M, P, C P$ & $\mathrm{~F}$ & Prunus americana & Wid Plum & M-DiF & $M, P$ & $F, N_{t} L$ \\
\hline Oxydendrum arboreum & Sounwood & D/F-S & $M, P, C P$ & $\mathrm{~N}$ & Prunus angustifolia & Chickasaw Plum & $\mathrm{D} / \mathrm{F}$ & $P, C P$ & $\mathrm{~F}, \mathrm{~N}, \mathrm{~L}$ \\
\hline Persea borbonia & Redbay & W-MF-S & $\mathrm{CP}$ & $\mathrm{C}, \mathrm{F}, \mathrm{L}$ & Prunus caroliniana & Carolina Laurel Cherry & M-D/F-P & $C P$ & $\mathrm{C}, \mathrm{F}, \mathrm{N}, \mathrm{L}$ \\
\hline Pinus echinata & Shortleaf Pine & D/F-P & $M, P, C P$ & $\mathrm{C}, \mathrm{S}, \mathrm{L}$ & Prunus pensyivanica & Fire Cherny & M-DiF & M & $F, N, L$ \\
\hline Pinus palustris & Longleaf Pine & $\mathrm{D} / \mathrm{F}$ & $P, C P$ & $\mathrm{C}, \mathrm{S}$ & Rhus copallina & Winged Sumac & M-DIF-P & M.P.CP & F,N L \\
\hline Pinus strobus & Eastem White Pine & $\mathrm{D} / \mathrm{F}$ & $\mathrm{M}, \mathrm{P}$ & $\mathrm{C}, \mathrm{S}$ & Rhus glabra & Smooth Sumac & $M-D / F-P$ & $M, P, C P$ & $\mathrm{~F}, \mathrm{~N}, \mathrm{~L}$ \\
\hline Pinus taeda & Loblolly Pine & $M-D / F$ & $\mathrm{M}, \mathrm{P}, \mathrm{CP}$ & $\mathrm{C}, \mathrm{S}, \mathrm{L}$ & Salix caroliniana & Carolina Wilow & W-MFF-S & P.CP & $\mathrm{L}$ \\
\hline Platanus occidentalis & Sycamore & MF-P & $M, P, C P$ & $\mathrm{~s}$ & Sambucus canadensis & Elderberry & W-MF-P & $M, P, C P$ & $\mathrm{~F}$ \\
\hline Prunus serotina & Black Cherry & M-D/F & $M, P, C P$ & $F, N, L$ & Sorbus americana & Mountain-Ash & MFF-P & M & $\mathrm{F}$ \\
\hline Quercus alba & White Oak & M-D/F-P & M,P.CP & $S, L$ & Symplocos tinctoria & Sweetleaf & M-D/F-S & $M, P, C P$ & $\mathrm{~S}, \mathrm{~N}, \mathrm{~L}$ \\
\hline Quercus coccinea & Scarlet Oak & D/F-P & $M, P$ & $S, L$ & Vibumum prunifolium & Black Haw & M/F-S & $M, P, C P$ & $\mathrm{~F}, \mathrm{~L}$ \\
\hline Quercus falcata & Southem Red Cak & M-D/F-P & $M_{1} P_{C} C P$ & $S, L$ & Vibumum rufidulum & Rusty Blackhaw & DIF-S & P,CP & $F, L$ \\
\hline Quercus michauxii & Swamp Chestnut Oak & MF-P & $P, C P$ & $\mathrm{~S}, \mathrm{~L}$ & \multirow{2}{*}{\multicolumn{5}{|c|}{ Small shrubs }} \\
\hline Quercus nigra & Water Oak & M-D/F-P & $P, C P$ & $S, L$ & & & & & \\
\hline Quercus pagoda & Cherrybark Oak & MiF-P & $P, C P$ & $S, L$ & Callicarpa americana & American Beautyberry & M-D/F-S & $P, C P$ & $\mathrm{~F}$ \\
\hline Quercus phelllos & Willow Oak & W-MF-P & $P, C P$ & $S, L$ & Calycanthus floridus & Sweetshrub & MP-S & $M, P$ & $\mathrm{~N}$ \\
\hline Quercus rubra & Red Oak & MF-P & $M, P$ & $S, L$ & Ceanothus americanus & New Jersey Tea & M-D/P-S & $M, P, C P$ & $S, N, L$ \\
\hline Quercus shumardii & Shumard Oak & MFF-P & $\mathrm{PCP}$ & SL & \multicolumn{2}{|c|}{ Cephalanthus occidentalis Buttonbush } & W-MF-P & $M_{1}, P_{1}, P P$ & $\mathrm{~S}, \mathrm{H}, \mathrm{N}$ \\
\hline Quercus stellata & Post Oak & D/F & $M, P, C P$ & $S, L$ & Clethra alnifolia & Sweet Pepperbush & WiF-S & $\mathrm{P}, \mathrm{CP}$ & $\mathrm{F}, \mathrm{H}, \mathrm{N}$ \\
\hline Quercus velutina & Black Oak & M-D/F-P & M.P.CP & $S, L$ & \multirow{2}{*}{$\begin{array}{l}\text { Corylus americana } \\
\text { Euonymus americana }\end{array}$} & Hazelnut & MF-S & $M, P$ & s \\
\hline Quercus virginiana & Live Oak & $\mathrm{D} / \mathrm{F}$ & $\mathrm{CP}$ & $C, S, L$ & & Strawberrybush & MP-S & $M, P, C P$ & $s$ \\
\hline Robinia pseudbacacia & Black Locust & M-D/F-P & M.P & $S, L$ & Gaylussacia dumosa & Dwarf Huckleberry & M-D/F-P & $\mathrm{M}, \mathrm{P}, \mathrm{CP}$ & $\mathrm{F}, \mathrm{N}, \mathrm{L}$ \\
\hline Salix nigra & Black Willow & W-MF-S & $M, P, C P$ & L & \multirow{2}{*}{$\begin{array}{l}\text { Gaylussacia frondosa } \\
\text { Hydrangea arborescens }\end{array}$} & Blue Huckleberry & MF-P & $P, C P$ & $\mathrm{~F}, \mathrm{~N}, \mathrm{~L}$ \\
\hline Sassafras albidum & Sassafras & M-DIF-P & $M, P C P$ & $F, L$ & & Wild Hydrangea & MP-S & $M, P$ & $\mathrm{~S}, \mathrm{~N}$ \\
\hline Taxodium distichum & Baldcypress & W-MFF-P & $\mathrm{CP}$ & $\mathrm{s}$ & \multirow{2}{*}{$\begin{array}{l}\text { llex glabra } \\
\text { ltea virainica }\end{array}$} & Inkberry & MF-P & $P, C P$ & $\mathrm{C}, \mathrm{F}, \mathrm{N}, \mathrm{L}$ \\
\hline Tilita americana & Basswood & MFF-P & $M, P C P$ & S.N.L & & Virginia Willow & W-MIP-S & $\mathrm{M}, \mathrm{P}, \mathrm{CP}$ & $\mathrm{S}, \mathrm{N}$ \\
\hline Tsuga canadensis & Eastern Hemlock & MP-S & M,P & $\begin{array}{ll}0, \mathrm{~N}, \mathrm{~L} \\
\mathrm{C}, \mathrm{S}\end{array}$ & \multirow{2}{*}{$\begin{array}{l}\text { Kalmia latiolia } \\
\text { Leucothoe axillanis }\end{array}$} & Mountain Laurel & M-DIF-S & $\mathrm{M}, \mathrm{P}, \mathrm{CP}$ & $\mathrm{C}, \mathrm{H}, \mathrm{N}$ \\
\hline Ulmus alata & Winged Elm & M-DiF-P & $M, P, C P$ & SL & & Doghobble & W-MF-P & $\mathrm{M}, \mathrm{P}, \mathrm{CP}$ & $\mathrm{C}, \mathrm{N}$ \\
\hline Ulmus americana & American Elm & W-MFF-P & $M, P, C P$ & $S, L$ & Lindera benzoin & Spicebush & M-D/F-S & $M, P, C P$ & $F, L$ \\
\hline & Nollericant Lan & & & & Lyonia lucida & Fetterbush & MP-S & $P, C P$ & $\mathrm{C}, \mathrm{N}$ \\
\hline \multicolumn{5}{|c|}{ Small trees/shrubs $(10.30 \mathrm{ft})$} & \multirow{2}{*}{$\begin{array}{l}\text { Phoradendron serotinum } \\
\text { Rhododendron atanticum }\end{array}$} & Mistletoe & parasite & $M, P, C P$ & $F, L$ \\
\hline Aesculus pavia & Red Buckeye & M/P & $C P$ & $\mathrm{H}, \mathrm{N}$ & & Dwarf Azalea & W-D/F-P & $P, C P$ & $\mathrm{H}, \mathrm{N}$ \\
\hline Aesculus sylvatica & Painted Buckeye & MP & $P$ & $\mathrm{H}$ & \multirow{2}{*}{$\begin{array}{l}\text { Rhododendron } \\
\text { calendulaceum }\end{array}$} & & & & \\
\hline$\overline{\text { Soil moisture: } W}=$ wet: $M$ & $=$ moist $: D=d r y$ & & & & & Flame Azalea & M-D/P-S & M & $\mathrm{H}, \mathrm{N}$ \\
\hline & sun, $P=$ partial sh & & & & & & & & \\
\hline Region: $\mathrm{M}=$ mountains; $\mathrm{P}$ & & & & & & & & & \\
\hline die value: $\mathrm{C}=$ winter $\mathrm{c}$ & cover, $F=$ fleshy fruit $S$ & & & & & & & & \\
\hline
\end{tabular}




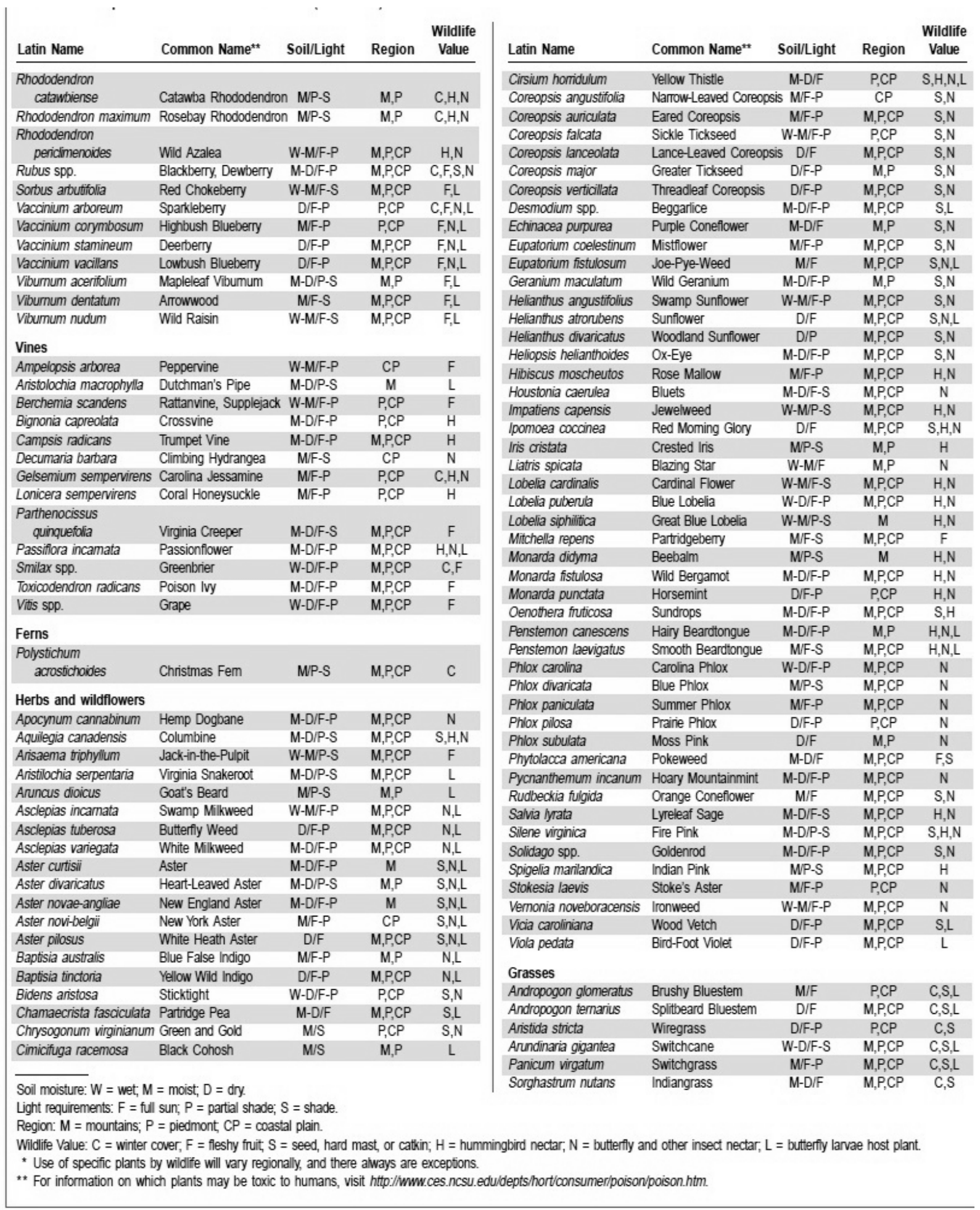




\section{Do Not Plant: Fort Bragg Non-Native and Invasive Plant List}

Table D3. Fort Bragg's IDG list of aggressive, invasive plant species that should not be planted on the installation, 2009 (Installation Design Guide for a Sustainable Fort Bragg).

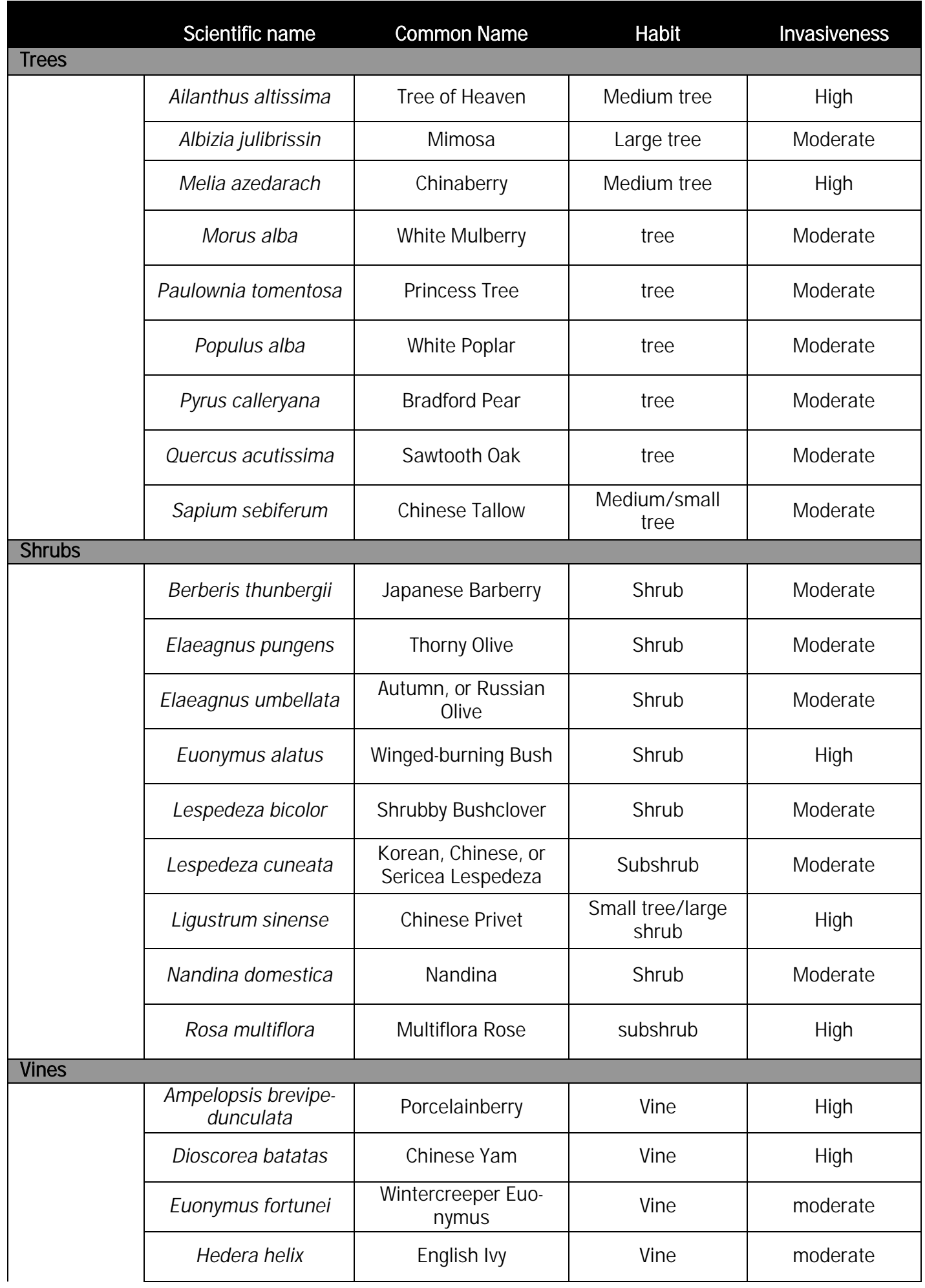




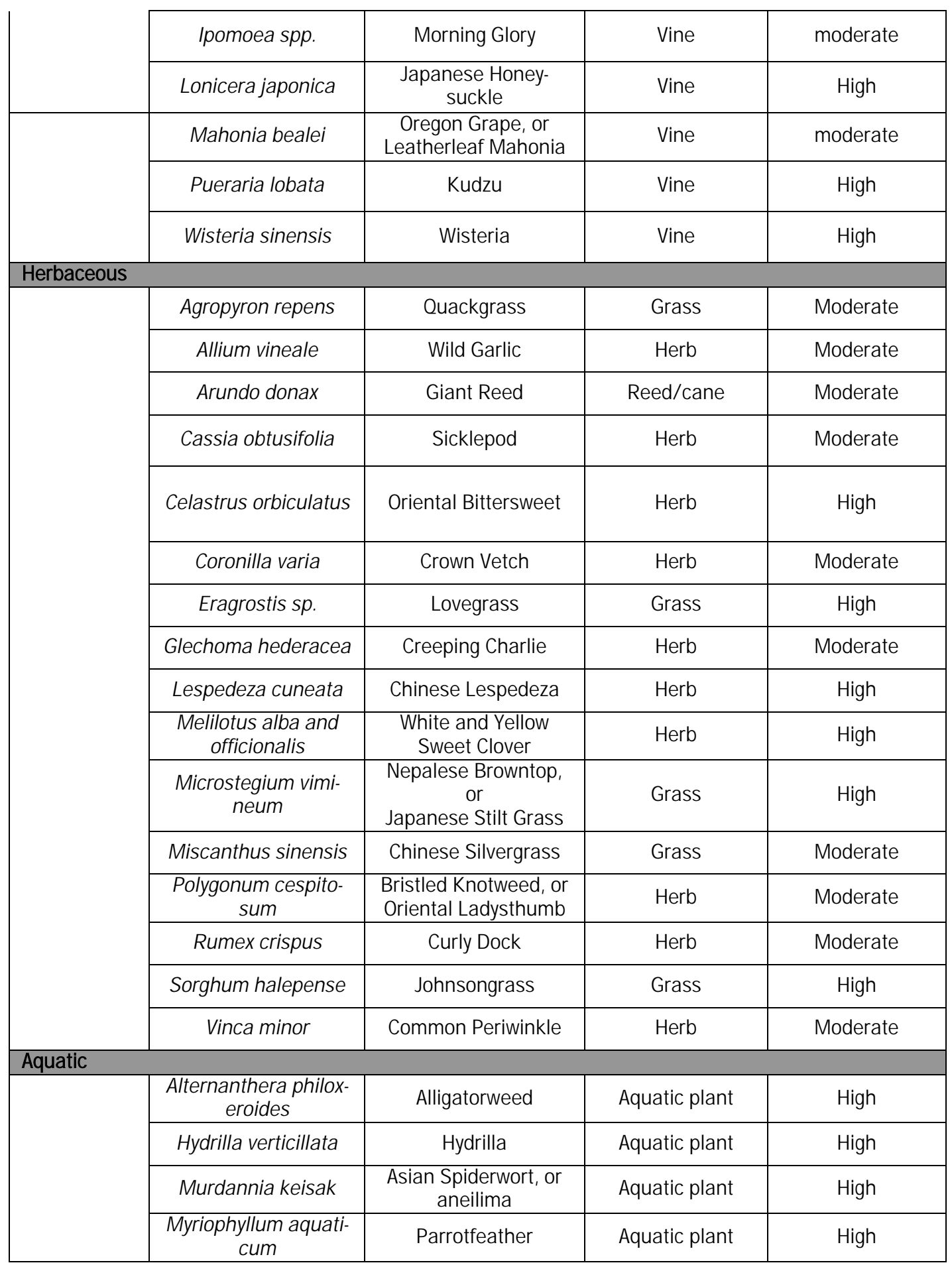




\section{Appendix E: Plant Vendors List for North Carolina}

Tables E1- E3 list NC nurseries certified by the North Carolina Department of Agriculture and Consumer Services as of 10 February 2010.

Please note that this information is not intended as an endorsement of the listed companies. Also, this list may not be exhaustive. Individual nurseries may not carry large numbers of wetland plants. No information was collected concerning the vendors' inspection or treatment of plants for pests and/ or diseases. Attempts should be made to obtain plants from an area as close to possible to the new planting area. Nurseries in or near North Carolina that carry wetland plants native to North Carolina may contact the NC Division of Water Quality - Wetlands/ 401 Unit at (919) 733-1786 if they wish to be added to the list. 
Table E1. Plant Vendors for North Carolina adapted froma list revised by Erich Hoffman, 4 August 2008 (ERDC-CERL).

\begin{tabular}{|c|c|c|}
\hline Suppliers & State & Web Address \\
\hline Adcock's Nursery & NC & http:/ / www.adcocksnursery.com/ home.html \\
\hline Longleaf Pine Seedling Suppliers & NC & http:// www.aubum.edu/academic/ forestry_wildlife/longleafalliance/landowners/ seedlings/ northcarolina.htm \\
\hline Native Elements Landscaping & NC & http:// www.nativeelements.com/ nursery.htm \\
\hline $\begin{array}{l}\text { Native Plant Vendor List for North } \\
\text { Carolina }\end{array}$ & NC & http:// faculty.ncwc.edu/mbrooks/pif/Home\%20Page\%20Links/ native_plant_vendor_list_for_nor.htm \\
\hline North Carolina Botanical Garden & NC & http://ncbg.unc.edu/pages/48/ \\
\hline $\begin{array}{l}\text { North Carolina Department of Envi- } \\
\text { ronmental and Natural Resources- } \\
\text { Division of Forest Services }\end{array}$ & NC & http:// www.dfr.state.nc.us/urban/native_trees/urban_native_select.asp \\
\hline North Carolina Native Plant Society & NC & http:// www.ncwildflower.org/ natives/ sources.htm \\
\hline $\begin{array}{l}\text { North Carolina Cooperative Exten- } \\
\text { sion Service }\end{array}$ & NC & http:// www.ashevillebotanicalgardens.org/Links/Suppliers\%20NativePlants.pdf \\
\hline The Nursery at Ty Ty & GA & http:// www.tytyga.com/ new_sitemap \\
\hline $\begin{array}{l}\text { Wholesale Nursery Grower Directo- } \\
\text { ry }\end{array}$ & & http:// www.growit.com/ plants/growers/ \\
\hline Wilcox Nursery & FL & http:// wilcoxnursery.com/ revSpecies.html \\
\hline
\end{tabular}

Table E2. Native plant vendor list (NC suppliers) for North Carolina compiled by the NC Division of Water Quality (NC Division of Water Quality 2010).

\begin{tabular}{|c|c|c|c|c|c|c|}
\hline NCSuppliers & Address & Gity & State & Zpp & Phone \# & Web Address \\
\hline Carolina Greenery & 375 Carthage Rd & West End & NC & 27376 & $910-947-3150$ & uww.carolinagreenery.com \\
\hline Carolina Native Nursery & 1126 Prices Creek Rd & Bumsville & NC & 28714 & $828-682-1471$ & uww.carokinanativenursery.com \\
\hline Gill Ide Native Plant Nursery & 621 Starburst Ln & Raleigh & NC & 27603 & 919-662-5566 & www.wetlandplantnursery.com \\
\hline Coastal Plain Consenvation Nursery & 3067 Conners Dr & Edenton & NC & 27932 & $252-482-5707$ & www.coastalplainnursery.com \\
\hline Colonial Acres Nursery & 2601 Hannah Ford Rd & Brevard & NC & 28712 & $828-884-4330$ & $\mathrm{~N} / \mathrm{A}$ \\
\hline Qure Nursery & 880 Buteo Ridge Rd & Pittsboro & NC & 27312 & 919-542-6186 & www.curenursery.com \\
\hline Growing Wild Nursery & 193 Murphy Rd & Burgaw & NC & 28425 & 910-259-6361 & uww.growingwildnursery.net \\
\hline Hanging Dog Valley Nursery & 2600 Boiling Springs Rd & Murphy & NC & 28906 & $828-837-7921$ & $\mathrm{~N} / \mathrm{A}$ \\
\hline
\end{tabular}




\begin{tabular}{|c|c|c|c|c|c|c|}
\hline NC Suppliers & Address & Gity & State & Zp & Phone \# & Web Address \\
\hline Hoffman Nursery & 5520 Bahama Rd & Rougemont & NC & 27572 & $800-203-8590$ & uww.hoffmannursery.com \\
\hline Lamtree Farm & 2323 Copeland Rd & Warrensville & NC & 28693 & $336-385-6144$ & unw.lamtreefarmnursery.com \\
\hline McLamb Nursery, Inc. & 640 Greenleaf Rd & Angier & NC & 27501 & 919-894-3709 & $\mathrm{N} / \mathrm{A}$ \\
\hline Meadowbrook Nurseries (We-Du) & 2055 Polly Spout Rd & Marion & NC & 28752 & 828-738-8300 & unw.we-du.com \\
\hline Mellow Marsh Farm & 1312 Woody Store Rd & Siler City & NC & 27344 & 919-742-1200 & uww.mellowmarshfarm.com \\
\hline Niche Gardens & 1111 Dawson $\mathrm{Rd}$ & Chapel Hill & NC & 27516 & 919-967-0078 & uww.nichegardens.com \\
\hline Plant Delights Nursery & 9241 Sauls Rd & Raleigh & NC & 27603 & $919-772-4794$ & uww.plantdelights.com \\
\hline Rarebird Nursery & 252 Collie Rd & Castalia & NC & 27816 & 919-853-2716 & www.rarebirdnursery.com \\
\hline Reems Creek Nursery, Inc. & 70 Monticello Rd & Weavenille & NC & 28787 & $828-645-3937$ & www.reemscreek.com \\
\hline Southeastern Native Plant Nursery & $36 \mathrm{Kel}-\mathrm{Co} \mathrm{Rd}$ & Chandler & NC & 28715 & 828-670-8330 & unw.southeasternnatives.com \\
\hline Tarheel Native Trees & 4339 Peele Rd & Clayton & NC & 27520 & 919-553-5927 & N/A \\
\hline
\end{tabular}

Table E3. Native plant vendor list (out-of-state suppliers) for North Carolina compiled by the NC Division of Water Quality (NC Division of Water Quality 2010).

\begin{tabular}{|l|l|l|l|l|l|l|}
\hline Out-of-State Supplier & Address & Gity & State & Zp & Phone \# & Web Address \\
\hline Bobtown Nursery & 16212 Country Club Rd & Melfa & VA & 23410 & $757-787-8484$ & www.bobtownnursery.com \\
\hline Carolina Nurseries & 739 Gaillard Rd & Moncks Comer & SC & 29461 & $843-761-8181$ & www.carolinanurseries.com \\
\hline Naturescapes Wetland Plants & 1581 Hosier Rd & Suffolk & VA & 22434 & $757-539-4833$ & N/A \\
\hline Pinelands Nursery, Inc. & 8877 Richmond Rd & Toano & VA & 23168 & $800-667-2729$ & www.pinelandsnursery.com \\
\hline Riverbend Nursery & 1295 Mt. Elbert NW & Riner & VA & 24149 & $540-763-3362$ & www.riverbendnursery.com \\
\hline Virginia Natives & P.O. BoxD & Hume & VA & 22639 & $540-364-1665$ & N/A \\
\hline Woodlanders, Inc. & 1128 Colleton Ave & Aiken & SC & 29801 & $803-648-7522$ & www.woodlanders.net \\
\hline
\end{tabular}




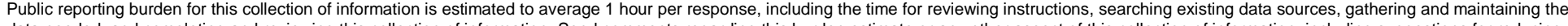

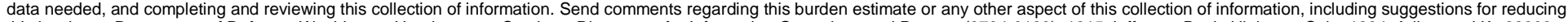

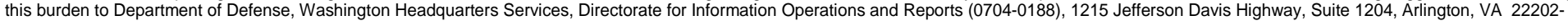

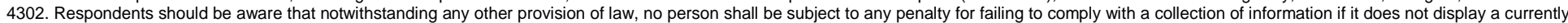
valid OMB control number. PLEASE DO NOT RETURN YOUR FORM TO THE ABOVE ADDRESS.
1. REPORT DATE (DD-MM-YYYY)

\section{REPORT TYPE}
3. DATES COVERED (From - To)

7-01-2011

Final

\section{TITLE AND SUBTITLE}

Fort Bragg Old Post Historic District Landscape Report

5a. CONTRACT NUMBER

5b. GRANT NUMBER

5c. PROGRAM ELEMENT

6. AUTHOR(S)

Megan Weaver Tooker, Ellen Hartman, and Adam Smith

5d. PROJECT NUMBER

MIPR

5e. TASK NUMBER

5f. WORK UNIT NUMBER

MIPR9GCERP3431

7. PERFORMING ORGANIZATION NAME(S) AND ADDRESS(ES)

U.S. Army Engineer Research and Development Center (ERDC)

Construction Engineering Research Laboratory (CERL)

PO Box 9005,

Champaign, IL 61826-9005

8. PERFORMING ORGANIZATION REPORT NUMBER

ERDC/ CERL SR-11-1

\section{SPONSORING I MONITORING AGENCY NAME(S) AND ADDRESS(ES)}

U.S. Army Garrison, Fort Bragg

Cultural Resources Management Program, Bldg 3-1333

Directorate of Public Works

Fort Bragg, NC 28310
10. SPONSOR/MONITOR'S ACRONYM(S)

11. SPONSOR/MONITOR'S REPORT NUMBER(S)

12. DISTRIBUTION / AVAILABILITY STATEMENT

Approved for public release; distribution is unlimited.

13. SUPPLEMENTARY NOTES

\section{ABSTRACT}

This document provides an inventory and evaluation of the historic landscapes within the Old Post Historic District (OPHD) at Fort Bragg, and serves to meet the requirements for Federal agencies to address their cultural resources, defined as any prehistoric or historic district, site, building, structure, or object, specifically, Section 110 that requires Federal agencies to inventory and evaluate their cultural resources.The report discusses the OPHD layout and design, its periods of significance, and historic landscapes and landscape features significant to the district. Several significant landscapes within the OPHD are identified, including the parade ground, Normandy Heights and Bastogne Gables Housing Areas, Ryder Golf Course, polo field, mule barn area, support buildings landscape such as the chapel, theater, headquarters, Bachelor Officers’ Quarters, Officers' Club, former hospital and nurses' quarters and barracks, and the industrial area. Important character-defining open spaces within the contributing landscapes include the parade field, polo field, Ryder golf course, Bowley Field, Ruth Field, the traffic circle, former "civic center” area, chapel area, and the triangular areas in front of the old hospital and headquarters. This report also includes planting recommendations for significant landscapes within the OPHD to improve the integrity and create historic continuity within the district.

\section{SUBJECT TERMS}

Fort Bragg, North Carolina, Old Post Historic District, OPHD, Historic Landscapes, Cultural Resources Management, Beaux Arts Planning, Field Artillery Training Center, Interwar Era Installation Planning and Design

\begin{tabular}{|c|c|c|c|c|c|}
\hline 16. SECURITY C & IFICATION OF: & & 17. LIMITATION & 18. NUMBER & 19a. NAME OF RESPONSIBLE PERSON \\
\hline $\begin{array}{l}\text { a. REPORT } \\
\text { Unclassified }\end{array}$ & $\begin{array}{l}\text { b. ABSTRACT } \\
\text { Unclassified }\end{array}$ & $\begin{array}{l}\text { c. THIS PAGE } \\
\text { Unclassified }\end{array}$ & SAR & 246 & $\begin{array}{l}\text { 19b. TELEPHONE NUMBER } \\
\text { (include area code) }\end{array}$ \\
\hline
\end{tabular}

